Florida International University FIU Digital Commons

3-26-2012

\title{
Fiscal Decentralization and Development: An Analysis of City Governments in Argentina and Mexico, 1980-2010
}

Heidi Jane M. Smith

Florida International University, heidi.smith@fiu.edu

DOI: $10.25148 /$ etd.FI12050219

Follow this and additional works at: https://digitalcommons.fiu.edu/etd

\section{Recommended Citation}

Smith, Heidi Jane M., "Fiscal Decentralization and Development: An Analysis of City Governments in Argentina and Mexico, 1980-2010" (2012). FIU Electronic Theses and Dissertations. 613.

https://digitalcommons.fiu.edu/etd/613 


\section{FLORIDA INTERNATIONAL UNIVERSITY}

Miami, Florida

FISCAL DECENTRALIZATION AND DEVELOPMENT:

AN ANALYSIS OF CITY GOVERNMENTS IN ARGENTINA AND MEXICO,

$1980-2010$

A dissertation submitted in partial fulfillment of the

requirements for the degree of

DOCTOR OF PHILOSOPHY

in

PUBLIC AFFAIRS

by

Heidi Jane M. Smith

2012 
To: Dean Kenneth Furton

College of Arts and Sciences

This dissertation, written by Heidi Jane M. Smith, and entitled Fiscal Decentralization and Development: An Analysis of City Governments in Argentina and Mexico, 1980-2010, having been approved in respect to style and intellectual content, is referred to you for judgment.

We have read this dissertation and recommend that it be approved.

Meredith Newman

Keith D. Revell

David Bray

Andrew Selee

Allan Rosenbaum, Major Professor

Date of Defense: March 26, 2012

The dissertation of Heidi Jane M. Smith is approved.

Dean Kenneth Furton College of Arts and Sciences

Dean Lakshmi N. Reddi University Graduate School

Florida International University, 2012 
(C) Copyright 2012 by Heidi Jane M. Smith

All rights reserved. 


\section{DEDICATION}

To my grandmothers Viola Selma Tina Wissow Grunwaldt and Frances Margret Walker Smith for their pursuit of an education and their gumption to preserve our strong family ties and values, even under some of the most difficult circumstances imaginable. 


\section{ACKNOWLEDGMENTS}

The pursuit and idea for this dissertation began some 15 years ago with a simple conversation. "What is the real difference between your town in Argentina and my town in Minnesota?" It was in 1997, when Eliana and I were reminiscing about our high school exchange programs to each other's countries. The debate presented thoughts such as the differences in education, culture, finance, and economic development of our respective towns. The conversation revealed that there were more similarities than differences between our societies, yet the lack of governmental structure and city organization seemed to be an apparent deficit in Latin America. While a simple conversation, this became my first analysis of development and administration and their impacts on society. Moreover, this began my interest in studying decentralization as a tool for reorganizing governments.

First and foremost, I would like to acknowledge my major professor and dissertation chair, Dr. Allan Rosenbaum. Since our first time meeting in an airport on our way to La Paz, Bolivia for a Ministerial Meeting on Decentralization in Latin America, a mission organized by the Organization of American States in 2001, he strongly encouraged me to pursue a doctoral degree at Florida International University. I appreciate the time we have spent together sharing ideas, current events, theoretical concepts, American political history and politics, but more importantly some great adventures. I am grateful for the humility and humor of my colleagues Cristina Rodríguez Acosta, Carlota Valdéz, Jeisson Rodríguez, Ilyana Albarrán and Rachel Emas within the Institute for Public Management and Community Service, where I worked for a majority of my time as a doctoral student at FIU. Additionally, I would like to thank Dr. David Bray, Dr. Keith Revell and Dr. Andrew Selee, who have each provided me with timeless advice and keen critical recommendations for this 
dissertation. Finally, I would like to highlight my last committee member and the chair of our public administration department, Dr. Meredith Newman. Her deep passion for the field and acute leadership skills have left me with one of the best role models and a true aspiration to follow in her footsteps.

I could not have completed this dissertation without institutional support. First, a predissertation field research grant from the Jack B. Gordon Public Policy Fellowship allowed me to conduct primary research during the summer of 2009. Additionally, FIU's Latin American and Caribbean Center, and particularly Dr. Cristina Eguizabal, helped identify the case studies. My colleagues in the Economic Policy and Summit Coordination office in the Bureau of Western Hemisphere Affairs at the U.S. State Department helped me to develop several ideas, which were presented as policy papers while I served there in 2009-10.

The Fulbright-García Robles grant permitted me to live in Mexico City and work at the Centro de Investigación y Docencia Económicas (CIDE) for the 2010-11 academic year. I'd like to acknowledge my advisors, colleagues and active critics: Dr. Mauricio Merino, Dr. Enrique Cabrero, Dr. Fausto Hernández, Dr. Guillermo Cejudo, Dr. Victor Figueras and Dr. Edgar Ramírez de la Cruz, who each provided me with guidance and advice to my dissertation. I am grateful to Dr. José Ramón Gil for allowing me to sit in his second year doctoral seminar at CIDE and to Oliver Meza and Alberto Cañas for their companionship and helpful explanations of the Mexican intergovernmental system.

The Tinker Foundation, Inc. travel grant arrived just in time in 2011 to make a final visit to the Argentine cases. I would like to thank Cristina Días of the Universidad de Rosario, Daniel Cravacuore of the Universidad de Quilmes, Pablo Costamagna of the IDB's Territorial Competitiveness Program in Rafaela for their assistance and time finding 
materials and proving fundamental introductions for interviews while in Argentina. Finally, FIU's University Graduate School's Dissertation Evidence Acquisition and Dissertation Year Fellowships helped provide funding for the essential time to finish my research and writing.

Overall, this dissertation has included three individual trips to Argentina and a yearlong stay in Mexico in order to gather important interviews with local, state and national representatives. On site data gathering has helped me to better evaluate the perception and the current state of affairs of fiscal decentralization (and autonomy) and its relationship with local economic development within the region. I would also like to thank each person that I had to opportunity to speak with while conducting over 100 interviews during this time. For which I had the opportunity to learn their specific points of view on the subject. In order to keep the interviews confidential, I simply referred the job type of each of the public administrators in the text.

Finally, without friends to call, relax with and rely on, this dissertation could not have been completed. As such I'd like to thank Jorge Rebolledo, Mariela Vallejo in Mexico; Keith Eischeid, Megan Moriarty, Jessica Bagdonis, Jessica Salsbury and Karen Juckett in Washington D.C.; Erin and Warren Parker in Fort Lauderdale; and Eliana Dam, Luciana Bergamo, Ana Sol Molfese and Kate Barron Alacante in Argentina for their support and friendship. In particular, Gabriel Farfán has provided much needed support. Last but not least, I'd like to acknowledge my family: Thora, Leah, David, John and Heather Kilde and Robert K. and Jane M. Smith for their support, patience and love. Without you, I could not continue to follow my dreams and for that, I am deeply grateful. 


\title{
ABSTRACT OF THE DISSERTATION \\ FISCAL DECENTRALIZATION AND DEVELOPMENT: AN ANALYSIS OF CITY \\ GOVERNMENTS IN ARGENTINA AND MEXICO, 1980-2010
}

by

\author{
Heidi Jane M. Smith
}

Florida International University, 2012

Miami, Florida

\section{Professor Allan Rosenbaum, Major Professor}

This dissertation examines local governments' efforts to promote economic development in Latin America. The research uses a mixed method to explore how cities make decisions to innovate, develop, and finance economic development programs. First, this study provides a comparative analysis of decentralization policies in Argentina and Mexico as a means to gain a better understanding of the degree of autonomy exercised by local governments. Then, it analyzes three local governments each within the province of Santa Fe, Argentina and the State of Guanajuato, Mexico. The principal hypothesis of this dissertation is that if local governments collect more own-source tax revenue, they are more likely to promote economic development and thus, in turn, promote growth for their region.

By examining six cities, three of which are in Santa Fe-Rosario, Santa Fe (capital) and Rafaela_and three in Guanajuato-Leon, Guanajuato (capital) and San Miguel de Allende, this dissertation provides a better understanding of public finances and tax collection efforts of local governments in Latin America. Specific attention is paid to each city's budget authority to raise new revenue and efforts to promote economic development. The research also includes a large statistical dataset of Mexico's 2,454 municipalities and a 
regression analysis that evaluates local tax efforts on economic growth, controlling for population, territorial size, and the professional development. In order to generalize these results, the research tests these discoveries by using statistical data gathered from a survey administered to Latin American municipal officials.

The dissertation demonstrates that cities, which experience greater fiscal autonomy measured by the collection of more own-source revenue, are better able to stimulate effective economic development programs, and ultimately, create jobs within their communities. The results are bolstered by a large number of interviews, which were conducted with over 100 finance specialists, municipal presidents, and local authorities. The dissertation also includes an in-depth literature review on fiscal federalism, decentralization, debt financing and local development. It concludes with a discussion of the findings of the study and applications for the practice of public administration. 


\section{TABLE OF CONTENTS}

CHAPTER

PAGE

\section{INTRODUCTION TO THE STUDY}

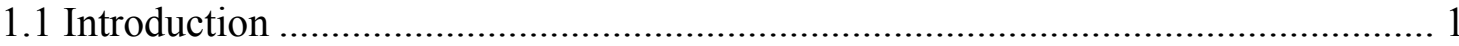

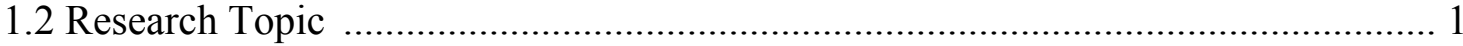

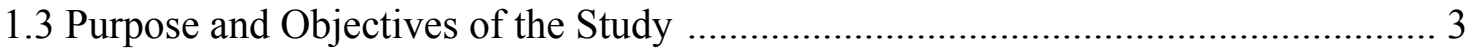

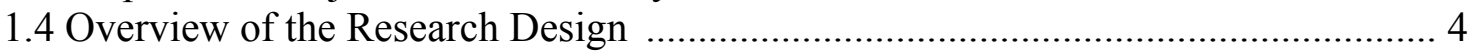

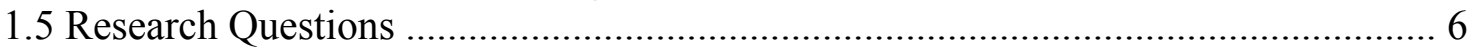

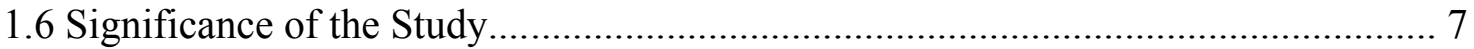

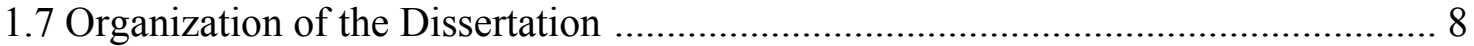

\section{THEORETICAL FRAMEWORK AND LITERATURE REVIEW}

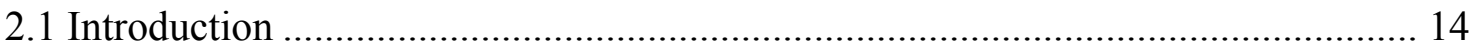

2.2 Public Choice Theories of Decentralization .................................................... 17

2.3 Political Decentralization Perspective ............................................................... 20

2.4 Administrative Decentralization Perspective ………......................................... 23

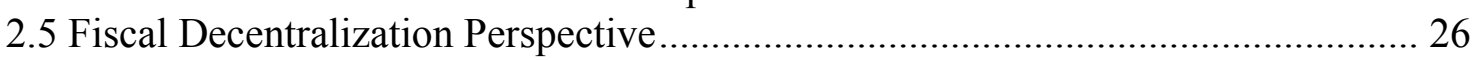

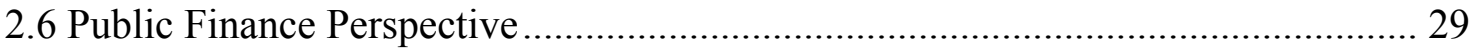

2.6 Local Economic Development Theory ............................................................ 36

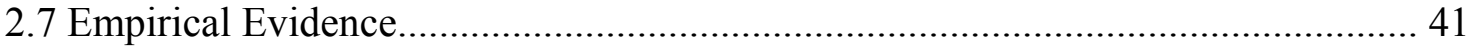

III. RESEARCH METHODOLOGIES

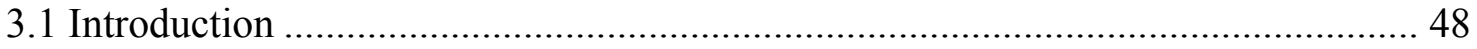

3.2 Research Questions..................................................................................... 49

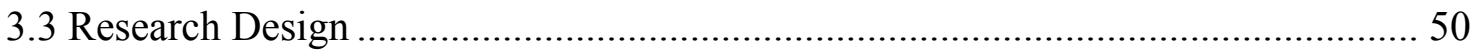

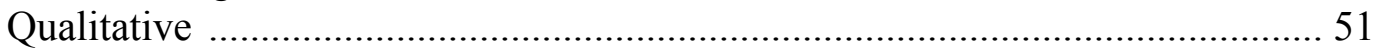

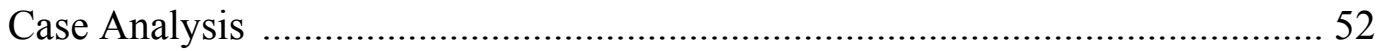

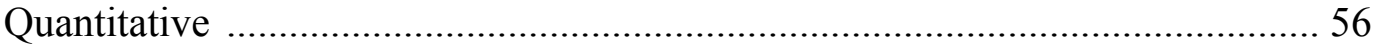

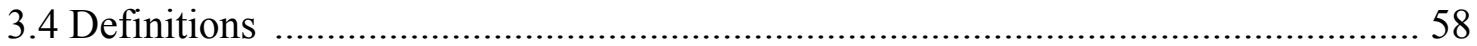

IV. THE HISTORY OF DECENTRALIZATION AND CENTRALIZATION IN ARGENTINA AND MEXICO

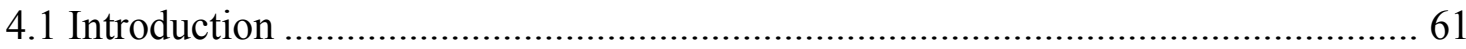

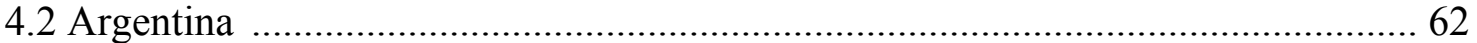

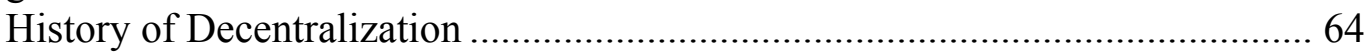

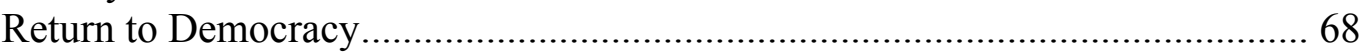

Recent History of Centralization.................................................................. 74

Problems with the Inter-Governmental System .............................................. 78

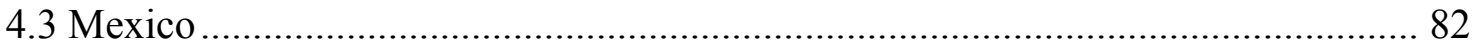

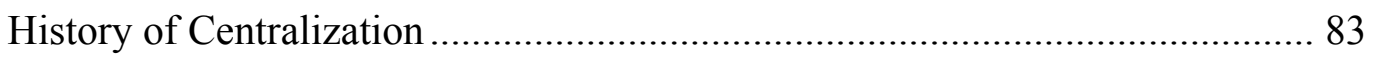

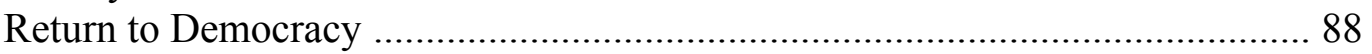

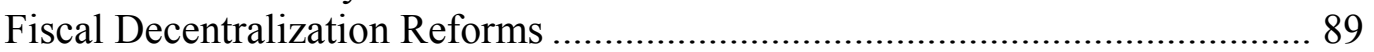

Problems with the Inter-Governmental System ................................................ 97

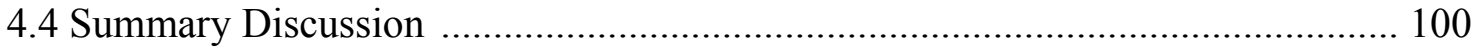




\section{INSTITUTIONAL CONTEXT FOR LOCAL GOVERNMENTS IN ARGENTINA AND}

MEXICO

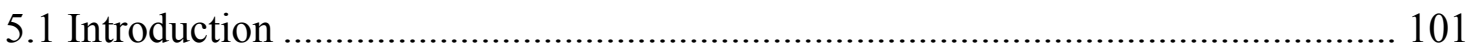

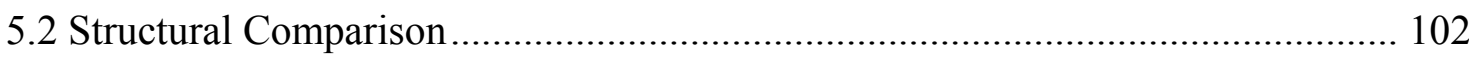

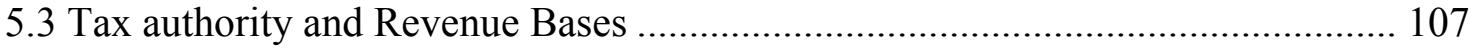

5.4. A Description of Subnational Public Debt .................................................... 110

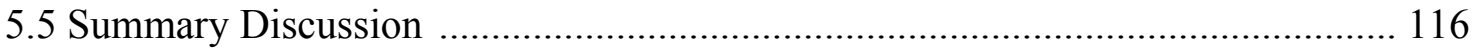

VI. ARGENTINA CASES

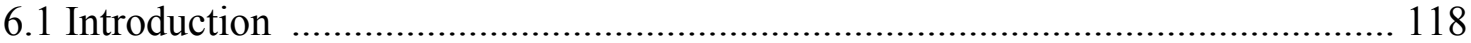

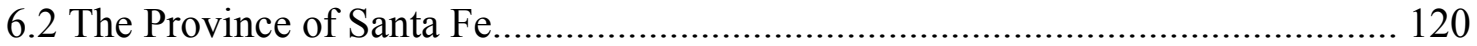

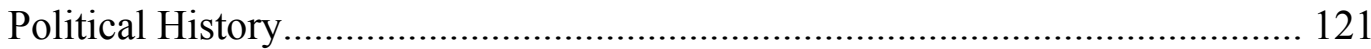

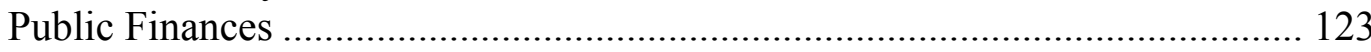

Economic Development Efforts …………………................................. 126

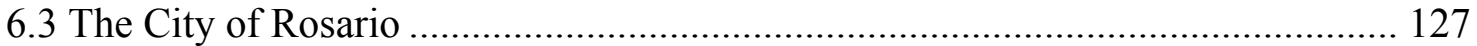

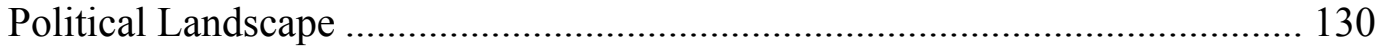

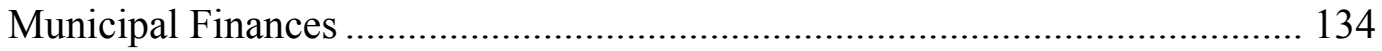

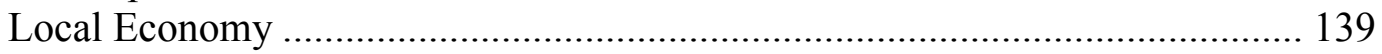

Economic Development Efforts ................................................................. 143

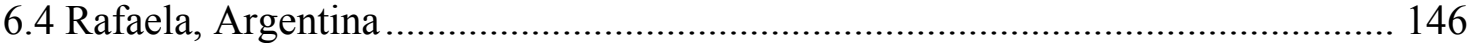

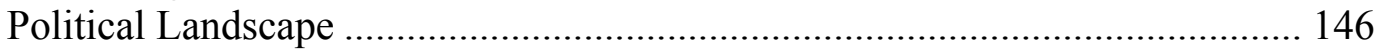

Municipal Finances .............................................................................. 148

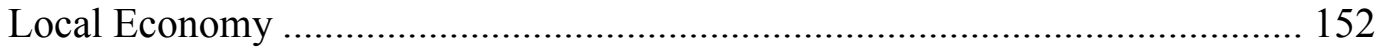

Economic Development Efforts .................................................................. 153

6.5 Santa Fe (capital), Argentina ..................................................................... 155

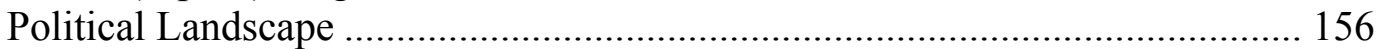

Municipal Finances ................................................................................ 156

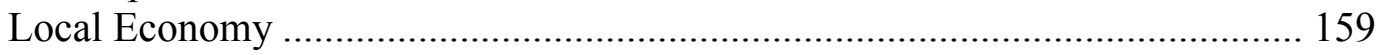

Economic Development Efforts .................................................................... 161

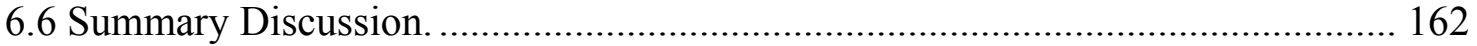

VII. MEXICO CASES

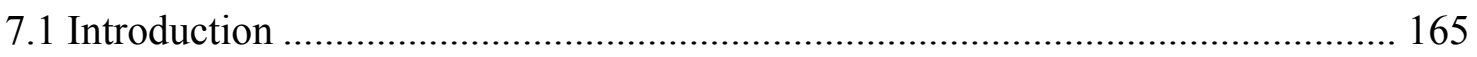

7.2 The State of Guanajuato, Mexico ………...................................................... 166

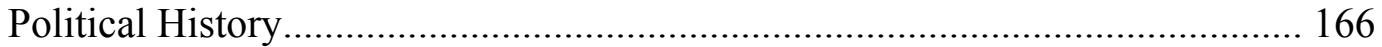

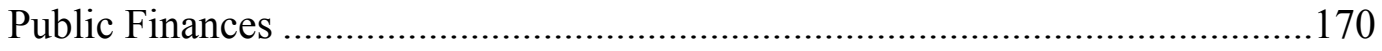

Economic Development and Regional Efforts.............................................. 172

7.3 The Capital City, Guanajuato …………............................................................. 177

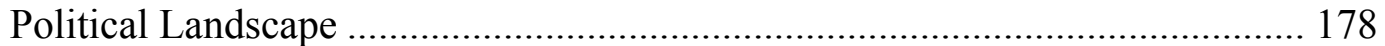

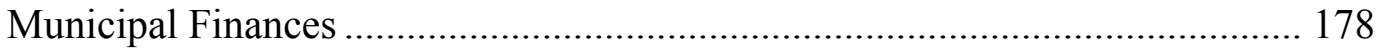

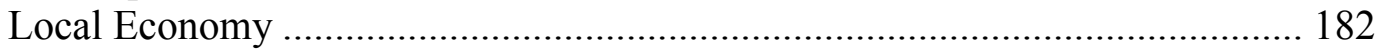

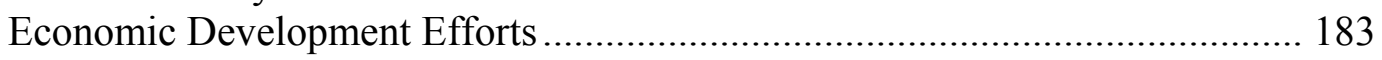

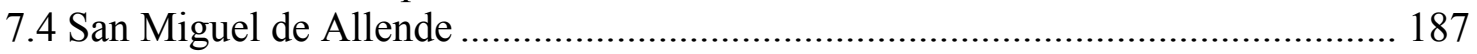

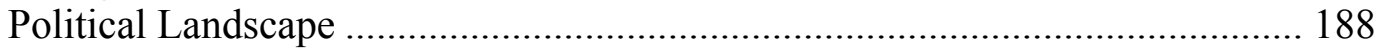

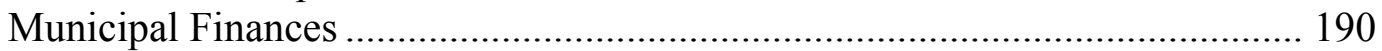




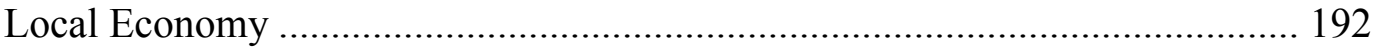

Economic Development Efforts .................................................................... 194

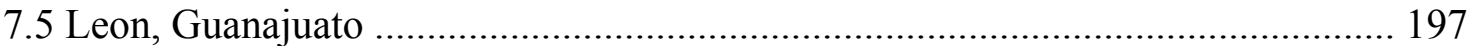

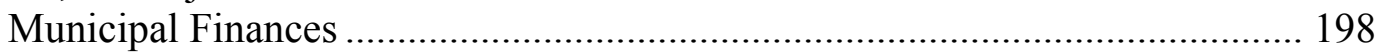

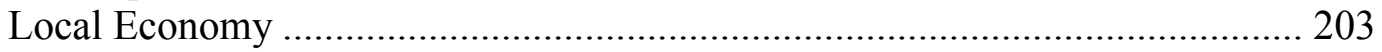

Economic Development Efforts ................................................................... 203

7.6 Summary Discussion ..................................................................................... 204

VIII. ANALYSIS OF THE SIX CASE STUDIES

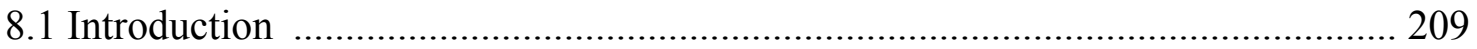

8.2 Budget Analysis of the Six Cities ...................................................................... 209

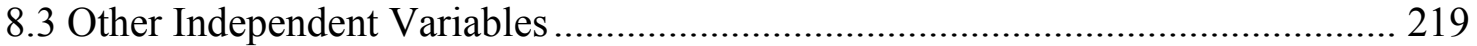

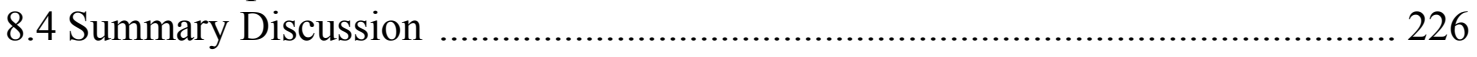

IX. MEXICO'S LOCAL FISCAL CAPACITY FOR ECONOMIC GROWTH: A QUANTITATIVE MODEL OF FISCAL AUTONOMY

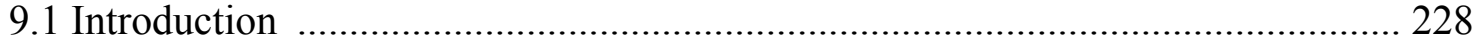

9.2 Evaluations of Mexican Fiscal Decentralization ............................................... 229

9.3 A New Approach and Data Analysis ............................................................ 232

9.4 Statistical Techniques and Results .............................................................. 233

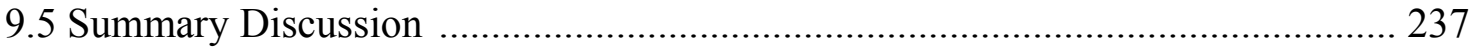

X. STATISTICAL ANALYSIS OF A SURVEY OF LOCAL AUTHORITIES IN LATIN AMERICA

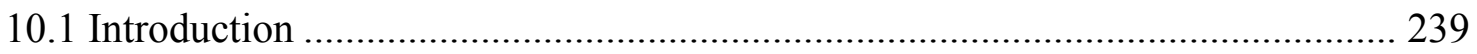

10.2 Theoretical Perspective............................................................................... 240

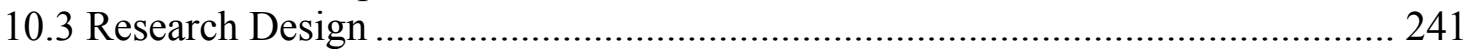

10.4 Statistical Techniques and Results ………................................................. 247

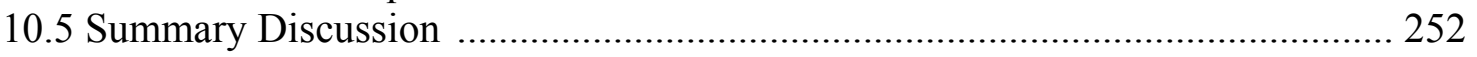

XI. DISCUSSION AND CONCLUSIONS

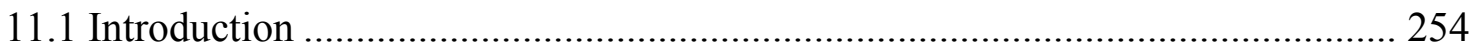

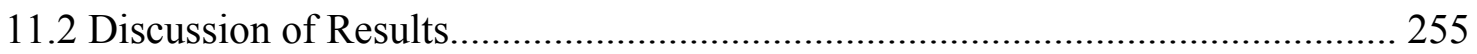

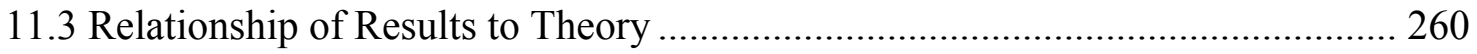

11.4 Implications for Further Research ................................................................ 265

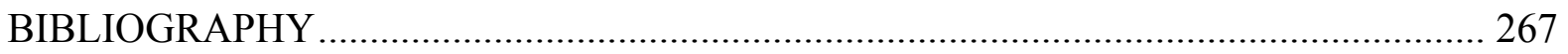

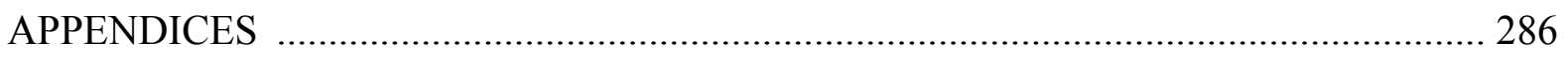

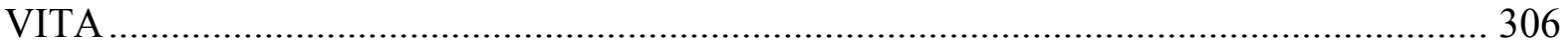




\section{LIST OF TABLES}

TABLE

PAGE

2.1 A Summary of Quantitative Research ........................................................ 43

3.1 Case Selection: Industry-type and Size of Cities ............................................ 51

3.2 Revenue Generation Levels to Measure Autonomy ......................................... 53

City's Efforts at Revenue Collection ........................................................... 54

3.4 Local Economic Development Programs ..................................................... 55

3.5 Quantitative Analysis Indicators................................................................... 56

4.1 Argentina's Disaggregated Tax Percentage of GDP 2001-2008 …........................ 64

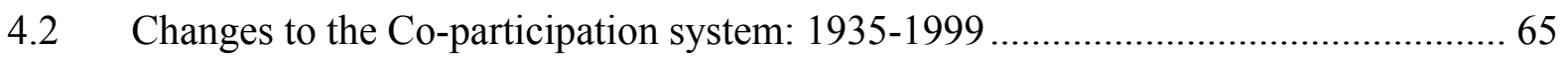

4.3 Principal Federal Transfers to Argentine Provincial Governments, 1973-1995........ 78

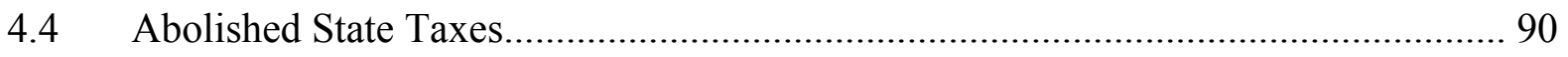

4.5 A Description of the Federal Transfers to States and Municipalities ....................... 94

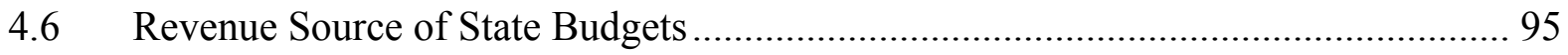

4.7 Problems with Mexico’s Legal Structure ........................................................ 97

4.8 Constitutional Controversies Presented in Mexico (1993-2005) ........................... 99

5.1 Federalist Constitutional Structure and Political decentralization......................... 103

5.2 Excerpts from Argentina's National Constitution ............................................... 104

5.3 Mexican Constitution: Article 115............................................................... 106

5.4 Mexico and Argentina Political and Territorial Organization ............................. 107

5.5 Autonomy Granted in Revenues Assignments to Local Governments ................. 109

5.6 Assignment of Taxes and Fees to Local Government ...................................... 110

6.1 Case Selection Santa Fe, Argentina …........................................................ 120 
6.2 Annual Transfers from the Federation received by Santa Fe 124

6.3 Rosario's Population according to Occupational Categories.................................... 140

6.4 Economic Development of the Metropolitan Rosario (1993-1998) ........................ 141

6.5 Rafaela's Population according to Occupational Categories................................... 152

6.6 Structure of Rafaela's Economy by Sectors (2004-2008) ……………………....... 153

6.7 Santa Fe's Capital Population according to Occupational Categories....................... 156

7.1 Governors of Guanajuato (1979-2012) ……………......................................... 169

7.2 Credit Ratings of the State of Guanajuato …………….................................... 172

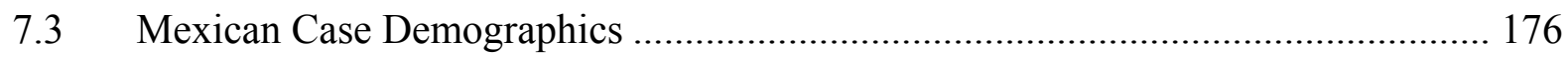

7.4 Guanajuato's (Capital) Municipal Presidents (1980-2012) ..................................... 177

7.5 Guanajuato's Economically Active Population (over 12 years of age) 2010 ........... 182

7.6 Guanajuato's Economic Production (2010) …………………................................ 183

7.7 Population of the Municipality of San Miguel de Allende (1980-2000) ................. 188

7.8 San Miguel de Allende's Municipal Presidents (1980-2012) ................................. 189

7.9 Constitution of the business sector in San Miguel de Allende 1998 ........................ 193

7.10 Municipal President of Leon 1980-2012 ………................................................ 198

7.11 Leon's Economically Active Population by Sector ................................................. 203

8.1 Cities, Population, GDP and Budget Size of the Case Studies ............................... 211

8.2 Revenue Generation Levels to Measure in Autonomy ……………………........... 211

8.3 Revenue per capita 2008 (dollars) ................................................................. 214

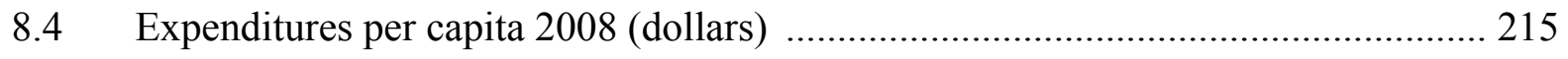

8.5 Other Factors leading to Economic Development Decisions ................................. 226

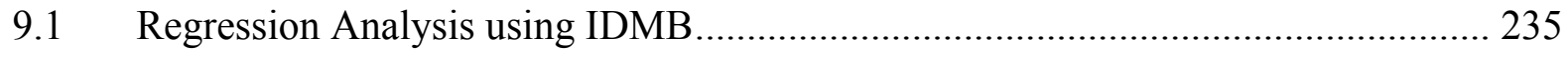


9.2 Key Public Finance Variables...................................................................... 237

9.3 Results of Economic Development on TOSR in Mexico ..................................... 238

10.1 Sample Frequencies of the Survey Statistics Description.................................. 244

10.2 Descriptive Statistics of Variables (obs=321) ............................................... 245

10.3 Business Friendliness Questions ................................................................. 246

10.4 Statistical Analysis Results Hypothesis \#1 Models 1 and 2 .............................. 248

10.5 Statistical Analysis Results Hypothesis \#1 Models 3 and 4 ............................... 250

10.6 Statistical Analysis Results Hypothesis \#2 and 3 .......................................... 250 


\section{LIST OF FIGURES}

FIGURE

PAGE

2.1 Latin American Subnational Revenues 1997-2006 (as percentage of GDP) ........... 30

2.2 Latin American Subnational Expenditure 1997-2006 (as percentage of GDP) ........ 30

2.3 Tax Revenue Compared with OECD averages (as percentage of GDP) ................. 31

2.4 Latin American Tax Revenues 1990-2008 (as percentage of GDP) ....................... 32

4.1 Argentine Revenue Sharing, 1973-1995 (Percent of Total Transfers) .................... 67

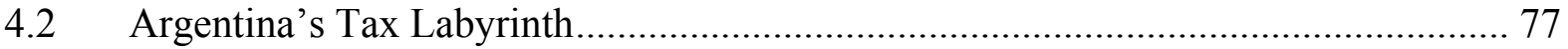

4.3 Difference between Municipal Local Revenue and Federal Transfers in Mexico ..... 92

5.1 Total Tax Revenue of Mexico and Argentina 1990-2009 (as percentage of GDP)...108

5.5 Santa Fe's Public Debt Ratios to Revenue (in thousands of pesos) ....................... 111

5.6 Total Debt Compared to a Selection of State Debt in Mexico (2000-08) .............. 113

5.7 Types of Loans Mexican States are Accruing (data from 2008) ........................... 114

6.1 The Province of Santa Fe Budget 1991-2009 ................................................... 123

6.2 Rosario Total Expenditures Revenue v. TOSR .................................................. 135

6.3 Rosario Total Disaggregated Spending (1999-2010) ......................................... 136

6.4 Sectoral Development of Rosario in US\$ Dollars ............................................. 139

6.5 Rafaela’s Total Expenditures Revenue TOSR (1989-2008) ................................. 150

6.6 Rafaela's Total Spending Disaggregated (1989-2008) ..................................... 151

6.7 Santa Fe's (capital) Total Expenditures Revenue v. TOSR (1985-2008) ............... 158

6.8 Santa Fe's (capital) Total Spending Disaggregated (1989-2008) ......................... 158

7.1 Guanajuato’s Capital Total Own-source Revenue (1993-2008) ........................... 180

7.2 Guanajuato's Spending Disaggregated (1993-2008) ......................................... 181 
7.3 San Miguel de Allende’ Disaggregated Spending (1993-2008) .............................. 191

7.4 San Miguel de Allende total own-source Revenue (1993-2008) ............................. 192

7.5 Leon's Spending Disaggregated (1993-2008) ……………………………....... 200

7.6 Leon's Capital Total Own-source Revenue (1993-2008) ....................................... 200

8.1 Percentage TOSR for Six Cities in Argentina and Mexico ................................... 212

8.2 Public Works Expenditures (as percentage of total) .............................................. 216

8.3 Subnational GDP Compared Guanajuato and Santa Fe (1993-2008)...................... 218 


\section{LIST OF ABBREVIATIONS AND ACRONYMS}

CEFP Centro de Estudios para las Finanzas Públicas, Mexican Chamber of Deputies (Muncipal Data base by the Mexican Congress)

CPI Income per Capita (CPI for Spanish acronym)

CONAPO Consejo Nacional de Población (Mexico’s census data)

DF $\quad$ Federal District (Districto Federal) of Mexico (Mexico City)

ECLAC United Nation's Economic Commission for Latin America and the Caribbean

FCS Federal Co-participation System

FDI Foreign Direct Investment

GFS Government Finance Statistics, International Monetary Fund

GNP Gross National Product (Producto Geografico Bruto-PIB)

GST Goods and Services Tax

IAF Inter-American Foundation

IDA International Development Assistance

IDB (IADB) Inter-American Development Bank

IDMB Indice de Desarrollo Municipal Basico

IFI International Financial Institutions

IMF International Monetary Fund

INAFED Instituto Nacional para el Federalismo y el Desarrollo Municipal

INEGI National Institute of Geography and Statistics (Instituto Nacional de Estadística, Geografía e Informática)

LAC Latin America and the Caribbean Region

LCGG La Ley General de Contablidad Gubernamental (Mexico’s General Government Accounting Law) 


$\begin{array}{ll}\text { LED } & \text { Local Economic Development } \\ \text { NGOs } & \text { Non-Governmental Organizations } \\ \text { OAS } & \text { Organization of American States } \\ \text { OECD } & \text { Organization for Economic Cooperation and Development } \\ \text { PAN } & \text { National Action Party (Partido Acción Nacional) } \\ \text { PJ } & \text { Partido Justicialista } \\ \text { PPS } & \text { Partido Progreso Social } \\ \text { PRI } & \text { Institutional Revolutionary Party (Partido Revolucionario Institucional) } \\ \text { PRD } & \text { Democratic Revolution Party (Partido de la Revolución Democrática) } \\ \text { PRONASOL } & \text { Mexico's Programa National de Solidaridad } \\ \text { SME } & \text { Small and Medium Enterprise } \\ \text { UNF } & \text { Sub-national Finance } \\ \text { SNG } & \text { Sub-national Government } \\ \text { WB } & \text { World Bank } \\ \text { UND } & \text { Value Added Tax } \\ \text { United Nations Development Program }\end{array}$




\section{CHAPTER I}

\section{INTRODUCTION TO THE STUDY}

\subsection{Introduction}

Local governments in Latin America are perceived to have low levels of autonomy, fiscal capacity, and human resources, which makes it difficult for them to deliver public services effectively and efficiently (Cabrero and Carrera 2002; Campbell 2003; Tulchin and Selee 2004). Arguably, with sufficient capacity, local governments could offer economic development programs such as tax incentives or education and training programs to help prepare a competitive workforce, which could ultimately boost their local economies (Blakely and Bradshaw 2002).

The purpose of this dissertation is to better understand the capacity of local governments in Latin America to support economic development by determining if there is a link between the degree of decentralization within a country and its local economic development. This study seeks to answer the following questions: What is the relationship between decentralization and local economic development? Are more fiscally autonomous cities in Latin America better able to promote local economic development programs? What incentives do city governments have to increase their public revenue streams? How are cities paying for their local economic development programs?

\subsection{Research Topic}

Within Latin America, countries started to decentralize by entrusting state functions, such as implementing social policies, managing local budgets and contracting 
out public services to local governments in the early 1980s (Montero and Samuels 2004). Coupled with various democratization movements throughout the same period, local elections became prevalent (Gibson 2004; Tulchin and Selee 2004). Scholars have associated the relationship of decentralization with local governance and democratic institution building (Rosenbaum 2009). A case example is Mexico, where decentralization has been linked to democratization (Bailey 1990; Cabrero and Carrera 2002; Gershberg 1995; Ward and Rodriguez 1995).

Increasingly, local governments have become a unit of analysis for research in the region and some academics have separated the decentralization movement into political, administrative, and fiscal reforms (Falleti 2010; Tulchin and Selee 2004). For example, Falleti (2005) argued that the process of decentralization is of a sequential nature, which begins with administrative reforms (devolving authority), then moves to creating a political framework (local elections) and, finally, establishes autonomous municipalities with the fiscal capacity to manage their own resources. She suggested that this final element, setting up decentralized financial reforms, promoting fiscal incentives and encouraging revenue systems to emerge from below, has proven to be difficult to implement. Recent scholarly and policy attention has focused on the last element, fiscal decentralization or the "transfer of expenditure responsibilities and revenue assignments to lower levels of government" (Escobar-Lemmon 2001; Gibson 2004; Litvack and Seddon 1998; Wiesner 2003). Empirical research has tested the effects of fiscal decentralization on economic development with several large-scale quantitative studies that found diverse outcomes (Davoodi 1998; De Mello 2001; Glaeser, Scheinkman, and Shleifer 1995; Martinez-Vazquez and McNab 1997; Rodden 2004). Scholars explain the 
wide-ranging results in terms of the variation that exists among definitions and measures of such basic concepts as autonomy, fiscal decentralization and own-source revenue generation (Ebel and Yilmaz 2002; Rodden 2002; Rodden 2004). The present dissertation seeks to facilitate the better understanding of the current theoretical and empirical gaps in the literature by providing both a quantitative and qualitative analysis of six cities located in Argentina and Mexico and by describing their efforts to initiate innovative approaches to public finances and the promotion of economic development programs.

\subsection{Purpose and Objective of the Study}

The purpose of the study is to analyze how local governments in Latin America function, manage, and fund local economic development (LED) programs. It discusses the local government's profile and activity, the contribution of LED to the development and growth of large metropolitan and midsize cities and small towns in the region. The specific objectives of this dissertation are:

- to provide a historic and comparative analysis of Argentina and Mexico's decentralization processes;

- to offer an overview of the role of Latin American local governments within the intergovernmental structure;

- to assess the role of local taxation as an agent of growth for cities in Latin America;

- and to provide a budget analysis of six cities and their effective use of revenues at the local level. 


\subsection{Overview of the Research Design}

The research utilizes two basic methodologies: qualitative and quantitative. The research provides a comparative analysis of the six cities in Argentina and Mexico. The cases were selected in two federalist countries in Latin America: Argentina and Mexico, which are undergoing a transition (George and Bennett 2005). Whereas traditionally Mexico has been very centralized (governed by a single national political party for over 70 years), it has increasingly become more decentralized with increasing degrees of municipal and states' rights. Argentina, on the other hand, has been traditionally decentralized (empowered by the provincial governments) and recently has become more politically and fiscally centralized through various national policies and tax reforms.

This dissertation includes an analysis of the subnational government reforms that affected inter-governmental relations between the national governments and the states. In addition, the study reviews recent fiscal reforms with regard to income generation and expenditures by the national, regional, and local governments. The timeframe for the analysis is from 1980 to 2010, thus incorporating major political and economic transformations in both counties' recent histories including the emergence of democratic governance. One goal is to understand how national decentralization policies impact local governments. To eliminate the impact of policy variation among state and provincial governments, the selected cities are in the same subnational governments - the state of Guanajuato in Mexico and the province of Santa Fe in Argentina. The cities include an industrialized city, a state capital and a small to mid-size town in each country as a means to take into account the impact of variation in size, industrial strength and economic activity. 
Each of the six city governments has engaged in a range of measures to increase revenue for their local budgets. The research compares different types of interventions in terms of encouraging fiscal autonomy and contrasts them as regards the city investments in economic development programs. Fiscal autonomy is evaluated as regards both budget composition and authority to finance these public programs. First, the independent revenue raising capability within the budget is measured. This is the input of local revenues such as property taxes, fees, fines and loans totaled and subtracted by intergovernmental transfers and international or philanthropic aid, which is calculated into a variable of Total Own-Source Revenue (TOSR). Next, the fiscal authority of each city, such as its ability to raise taxes and fees, issue public debt, re-evaluate property and change its tax rate, is examined. This includes a review of each city's legal frameworks. The research further compares the six cities as regards to their efforts to promote economic development programs (measured as the dependent variable). The specific programs of each city, for example job fairs, training centers, or marketing locally produced products are reviewed. The factors that may result in increased economic development examined include: inter-governmental relations, political ideology, geography (i.e. history and cultural legacy), mayoral leadership, and the professional development (i.e. educational level) of the public employees.

A large-scale quantitative phase of the research further tests the case study results. An econometric model is used to evaluate if own-source taxes as a percentage share of total revenue helps economic growth measured as gross domestic product (GDP). The model uses data obtained from Mexico's National Institute of Geography and Statistics (INEGI) and the Chamber of Deputies' Public Finance (CEFP) data on municipal income 
and expenditure data. By using Mexico as a single country case study with 2,454 municipalities, it provides a useful first quantitative test for Latin America.

Finally, to cross-reference and generalize the results throughout Latin America, a survey was distributed to authorities at a large conference of local governments to test these outcomes. The survey sought to determine how well local economic development programs work and the autonomy that the local authorities experienced. The sample includes cities throughout Latin America with a variety of population sizes and country origins. With these data, a multivariable analysis was conducted to better understand the perceptions of local authorities regarding the different types of decentralization (administrative, political, or fiscal). Specifically, the statistical analysis evaluated the relationship of city autonomy and efforts to create economic development programs and to the number of job created in each city.

\subsection{Research Questions}

This dissertation analyzes Argentina and Mexico's commitment to fiscal decentralization policies and their efforts at creating more fiscally autonomous local governments. It is hypothesized that if a national government has a higher degree of commitment to fiscal decentralization policies, the country will be more likely to have fiscally autonomous municipalities. Autonomy is measured as a combination of total own-source revenue collection and the authority to exercise their local budgets.

Second, this dissertation examines the relationship between fiscal autonomy and a municipalities' commitment to economic development activities. This examination reviews the various city budgets and assesses their use of own-source revenues to invest in economic development programs. It is hypothesized that if a municipality is more 
fiscally autonomous, the city will be more likely to have allocated resources for economic development activities. Success is measured in terms of the number of such programs and the extent to which budget resources are allocated to them. It is assumed that if the local public official has more autonomy and uses it to establish programs that create jobs and related economic development programs, then local economies will grow and generate wealth for their communities.

\subsection{Significance of the Study}

This study addresses various policy issues. First, although Latin America has seen positive steady growth rates in the past decade, it is still the most unequal region of the world in terms of income distribution. Birdsall, De La Torre, and Menezes (2007) suggest that those inequalities inhibit future prosperity. Policy makers for the past quarter century have been searching for solutions to this problem. Decentralization is one such approach, but more research is needed to find the correlation between fiscal autonomy and its possible effects in improving the economic development of a city.

Second, scholars currently suggest that national governments in the region provide weak incentives for local governments to raise their own revenue (Weingast 2006; Wiesner 2003). In comparison to other areas of the world, Latin American countries generally collect a small percentage of their potential tax revenue. Suggesting a system of fiscal federalism, or the balancing of federal dollars with local needs, without devolving more fiscal authority to local governments, may be an ineffective approach to encourage local governments to tap new revenue streams (Bahl and Wallace 2005). More information is needed to understand the current inter-governmental context, with particular attention to the allocation of national revenues to subnational governments. 
Potentially, a city could find new sources of revenue to address social issues and pay for economic development programs at the local level. This would develop a new social equilibrium for public policies and have a direct impact on what level of government these policies should be carried out.

Third, international lenders are interested in financing loans to sub-national governments. For example, trust funds, guarantee funds or municipal bonds could provide new financial instruments for cities to invest in economic development programs (Campbell 2003). Additional research is needed to understand what types of economic development programs cities are establishing and how they are paying for them. This will help to better understand the decision-making processes of city officials.

\subsection{Organization of the Dissertation}

The dissertation is arranged into three sections: 1) theories and methods, 2) qualitative analysis and 3) quantitative analysis. Chapter I introduces the problem statement, purpose, and significance of the study. The conceptual basis of the study is also established. Chapter II reviews literature and research related to the broad topics of decentralization and economic development. It describes empirical studies that have been conducted and explains why a qualitative assessment of municipal fiscal data is aslo necessary. The methodology in the study is presented in chapter III and includes the research design, sample selections, data collection tasks and the data analysis procedures. Results from the qualitative research effort are presented in chapters IV-VIII and the quantitative analysis in chapters IX-X.

Chapter IV uses a comparative historical review of the federal experience in each country to identify the recent trends towards increased decentralization in Mexico and 
greater centralization in Argentina. The contribution of overcoming a dictatorship in the late 19th century and a civil war (1910-20) meant that Mexico had a difficult time consolidating political power and developing as a federation. While Mexico was a centralized federation for much of the 20th century, the federal government began to decentralize when opposition party members came into power in the 1980s. It was only when the Partido Revolucionario Institucional (PRI) political machine was thoroughly dismantled in 2000 that democracy and decentralization really took root in the country. Whereas Mexico's decentralization reforms have been primarily administrative and political, its fiscal policies have concentrated on revenue redistribution through federally funded programs. Still the budget process, as a whole, is primarily managed by the executive power.

Argentina, for most of the 19th century, has been a loosely decentralized federation of caudillos, local land owning elites. Research suggests that when Juan Domingo Peron first became president in the 1940s, the country started to become more centralized (Benton 2001). His policies called for a strong role for the central government in order to provide services to urban workers in and around Buenos Aires. His party and policies drove Argentina into a spiral of political reforms, military dictatorships, and economic crises for most of the 20th century. From 1980-2010, power struggles between the provinces and the presidency reflected the emergence of a stronger hand by the executive branch of government in managing the country. Argentina's centralization of power can be further traced through examining the recent fiscal reforms developed to stabilize its faltering economy, especially after 2001. 
Next, chapter V describes the institutional context local governments in Argentina and Mexico. The chapter seeks to evaluate how decentralization reforms have affected the two regional subnational governments and the six cities as case studies. It is assumed that if Argentina becomes more centralized and Mexico more decentralized then local budgets will also change as a result. First, the chapter provides a comparison of the legal structures for each country. It demonstrates that the Argentine cities have more authority to initiate taxes, set rates and bases, and make more budget decisions then their Mexican counterparts. Mexico's local governments have limited authority to manage their budgets and are subject to changes made by the state governments.

Next, chapter $\mathrm{V}$ evaluates the public debt obligations of whether city officials take loans from private or publically financed banks such as the World Bank. The public finance literature highlights that debt decisions may provide additional fiscal autonomy for a city in terms of independent discretion to spend the additional recourses (Feiock, Jeong, and Jaehoon 2003; Fukasaku and Hausmann 1998). Arguably, scholars suggest that Argentina's debt defaulted and macro-economic instability after 2001 was largely the result of the provinces issuing too much debt. A problem of moral hazard occurred because the national government held the risk and bailed out the provinces (De Mello 2001; Feiock, Jeong, and Jaehoon 2003; Fukasaku and Hausmann 1998; HernandezTrillo and Jarillo-Rabling 2002). This research study finds that Argentina's subnational governments have more legal authority to take out loans-but the country has recently been tightening its rules by requiring the federal treasury to approve these loans. Mexico has long centralized its decision-making authority to the federal treasury, but has recently changed its laws to allow local governments to take out public debt from the private 
sector. Laws now require cities to provide two ratings and collateral in the form of revenue from future inter-governmental transfers. Both countries recent fiscal reforms allow debt capacity for local governments. Yet, Mexican cities have been able to take advantage of this benefit and take out more debt. This research found that the wealthier cities have better balance sheets to cover larger loans, but they also default more often.

Chapter VI and VII use a comparative case study approach to understand the effects of fiscal decentralization on creating locally based economic development programs. These two chapters evaluate the six cities selected, first Argentina (chapter V) and then Mexico (chapter VI), and uses a bottom up approach to see how federal decentralization reforms are transforming the local governments, focusing primarily on their budgets. In general, federal decentralization or centralization polices have had little effect on the authority and decisions that city's make over their budgets. Rather, in the case of Mexico, fiscal decentralization has allowed states more control over resources. In Argentina, there has been relatively little influence of the recentralization on the three case study's budgets. This study finds that the expenditure and revenue decisions for the case studies are not correlated with the degree of decentralization policies that the national governments have undergone.

After looking at the cases studies and the legal frameworks, chapter VIII focuses on the independent variables to explain why the cities capture more tax revenue and later spend it, or not, to improve their local communities. These other factors include the intergovernmental relations, geography (i.e. history and cultural legacy), mayoral leadership, and the professional development (i.e. educational levels) of the public employees. The most influential variable in all the cases is the inter-governmental relations that city 
administrators have with their state-level bureaucracies. This was found positive and significant for all cases in both Mexico and Argentina. Local politics within the city and across other levels of government is the most important factor for economic development to occur within a municipality. This was more fundamental than left or right based political ideology, the basic political situation or educational attainment of public employees. The political relationship between the local, state and national government seemed to be the most dominate factor for a majority of the six case studies. The influential variable of local politics is later quantitatively tested in chapter IX by using a survey of local authorities across Latin America and found to be positive for increases in economic development.

In general, the research found in the case studies (chapters VI and VII) that the amount that a city devotes to economic development programs is only a small part of the overall budget. A programmatic budget of several thousand dollars a year and a few dedicated employees does not directly equate to bringing millions of dollars into a local economy. Rather, city wealth is more important for its ability to either collect more taxes or bring more businesses into the community. A city's wealth is the precursor for local tax collection. Bigger local budgets make spending more possible on local economic development programming.

Chapter IX builds on the empirical knowledge from previous chapters to perform a large-scale $\mathrm{N}$ regression to test whether more own source revenue (local tax collection) helps economic development, measured as Gross Domestic Product. The statistical results found a positive relationship between economic development GDP and local tax collection by using municipal data from Mexico, over a span of 20 years. The 
endogeneity problem of whether tax collection is first necessary to help economic development or if economic development helps with local own source revenue collection by providing of a greater tax base, is tested. By using quantitative data from Mexico, the latter is supported. This statistical test is robust with a high R-squared, but there could be several intervening variables omitted from the model. One additional unexpected outcome finds public works (as a percentage of TOSR) expenditures are insignificant, but negatively correlated with economic development. More money spent on public works (as a percent of TOSR) does not translate into increased economic development (rise in GDP). This could mean that there is a high dependency by local government officials on inter-governmental grants. Furthermore, the fiscal equations for redistributing transfers for public works may be incorrect. Further analysis is needed to review how intergovernmental grants are created and distributed.

Finally, chapter $\mathrm{X}$ seeks to generalize the findings by using survey data from cities across Latin America. A regression model is used to test whether mayors and local authorities see decentralization essential for job creation. It demonstrates that mayors and local authorities are more concerned about political and administrative decentralization than fiscal decentralization. The responses from the surveys suggest that financial decisions are determined by the politics of intergovernmental relations. The results show that local authorities would rather depend on higher-level political connections than to collect more taxes. This shows respondents have a desire to continue rent-seeking higher-level government officials rather than finding independent revenue sources to manage their cities. 


\section{CHAPTER II}

\section{THEORETICAL FRAMEWORK AND LITERATURE REVIEW}

\subsection{Introduction}

Three decades of democratic experimentation in Latin America has been, in part, focused on government decentralization. Justified in terms of its ability to create both greater effectiveness and efficiency in governance, decentralization has been long associated with the empowering of local governments to encourage citizen participation in the decision-making process. The early writings of John Stuart Mill and Alexis de Tocqueville analyzed decentralization in conjunction with ideas such as representation, civil society participation and democratization.

Theoretically, decentralization is also a concept described, analyzed and advanced by public choice scholars such as Charles Tiebout (1956) and Richard Musgrave (1959). These scholars were primarily concerned with the economic priorities of downsizing the welfare state and reducing public expenditures, along with balancing budgets, contracting out services and delegating responsibilities to lower levels of the bureaucracy or directly to the civil society. The theory of public choice suggests that the lowest level of government puts forth the best delivery of services, for which the public will have a higher willingness to pay for those public goods. These theories have been conceptualized for developed countries but have not been tested for developing countries, such as those in Latin America. 
Since the 1980s, an increasing number of countries in Latin America have decentralized by entrusting state functions, such as promoting economic development, to local governments (Montero and Samuels 2004; Tulchin and Selee 2004). Initially, international financial sector endorsed this development idea (Bonvecchi 2010). A new focus on governance shortly followed and became prominent throughout the developing world. For example, Ebal and Yilma (2002) cite Dillinger's 1994 World Bank report, which declared that more than 60 developing countries with populations greater than five million claimed to have begun to transfer fiscal authority to local governments. Yet, skeptics of the idea consider decentralization as contributing more subnational debt by abusing soft budget constraints and inflicting moral hazard, therefore enlarging local bureaucracies, and ultimately causing macroeconomic instability (Diaz-Cayeros 2006; Dillinger and Webb 1999; Hernandez-Trillo and Jarillo-Rabling 2002; Rodden 2002; Rodden 2004; Stein 1999a). Arguably, the process of decentralization is far from complete within the region and the question still remains as to whether more fiscal decentralization policy can ensure financial stability while promoting economic development.

If the skeptics are wrong, there are several place-based development techniques that local governments could apply once they have a certain level of autonomy (Campbell 2003; Glaeser, Scheinkman, and Shleifer 1995; Ladd and Yinger 1989; Porter 1990; Roberts 2005). This includes developing tax incentive programs, providing education and training programs that can attract and/ or help prepare a competitive workforce and/ or offer loans or credits to entrepreneurs (Feiock 2004; Feiock, Moon, and Park 2008; Feiock, Steinacker, and Park 2009; Kwon, Berry, and Feiock 2009). By creating strong 
financial systems, cities can encourage investors locally, thereby stimulating economic development. The theory suggests that greater autonomy will motivate a more responsive local government, which will more effectively shape public policies that contribute to a community's needs. Local economic development theory suggests that this commitment and development strategy will assist communities to address the needs of the poor and promote growth for their societies (Bardhan and Mookherjee 2006; Besley and Coate 2002; Blair 1995; Blakely and Bradshaw 2002; de Mello 2008; Feiock and Jae-Hoon 2001; Feiock, Steinacker, and Park 2009; Feiock and Cable 1992; Kwon, Berry, and Feiock 2009; Malizia and Feser 1999; World Bank 2007).

The present dissertation tests whether the assumptions of the decentralization advocates are correct. Are fiscally autonomous cities more likely to promote economic development programs? The purpose of chapter II is to better understand the extensive literature that explains the relationship between decentralization and economic development. This chapter reviews several bodies of literature. First, it describes the theories of public choice, fiscal decentralization, and fiscal federalism. Then it provides an overview of how the concept of decentralization has been treated by Latin American scholars, in particular by dividing decentralization into political, administrative, and fiscal reforms. Next an overview of public finance literature is provided to understand how tax policy has been established within the region. Then local economic development theory is explained. This is followed by a description of empirical studies that have been done to test whether fiscal decentralization promotes economic development. 


\subsection{Public Choice Theories of Decentralization}

This study uses public choice theory to understand why national governments would decentralize. Oates' (1972) original premise derives from traditional neoclassical economists such as Charles Tiebout (1956) and Richard Musgrave (1959) who linked public choice to theories of federalism. These scholars suggest that fiscal decentralization is more efficient by first, allowing local governments to determine the appropriate level of service delivery, and second, by creating competition between local governments while allowing voters to move from one jurisdiction to another to obtain optimal preference of service provision. Oates (1995) added that decentralization plays an important role in the efficient production of services leading to more rapid economic growth. Fukasaku and de Mello (1999) suggest that decentralizing public service delivery will create efficiency gains that will in turn enhance growth (Fukasaku and Mello Jr. 1999; Fukasaku and De Mello 1998; Fukasaku and Hausmann 1998; Gavin and Hausmann 1998; Stein 1998). Peterson's (1995) functionalist theory suggests that the appropriate level of government should manage what is perceived to be the appropriate function. Peterson identifies distinctive levels of government that he believes are best able to manage the allocation or redistributive of activities. Whereas state and local governments allocate developmental funds such as those for infrastructure and roads, redistributive funds involve funding social programs to the poor and sick should be managed by the national government (Peterson 1995; Peterson 1981).

Musgrave (1959) argued local governments are equipped to design and administer development programs because market forces and political processes discipline them. Because city governments are close to citizens' demands, they are best able to renegotiate 
the fiscal bargain with taxpayers (Campbell 2003). It is the marginal resident and marginal businesses that determine the market value of property in a locality. Local governments give citizens a choice in the level and type of basic government services. Theory suggests that municipalities are better equipped to facilitate information about how to organize public services. Because citizens are likely to eschew income tax and rely more heavily on property taxes and user fees to pay for public goods, political pressure is minimized at the local level.

Some skeptics of decentralization argue that national governments should be in control of state resources to target development into specific areas of their countries (Manor 1999; Prud'homme 1995; Smoke 2005). The main argument suggests that central governments can better manage the high fixed costs for building infrastructure, which will provide spillovers into other regional areas of the country. Smoke (2005) contends that national governments, in particular in developing countries, have better access to information and international financial markets to plan targeted development activities. Manor (1999) suggests that after World War II, a centrally managed, mixed economy was sought to push for centralization in many developing countries.

In general, countries under communist influences in Latin America began similar centralization processes. Beginning in the 1970s, when military took control of national governments in their efforts to overthrow leftist sympathizers, several installed decentralized governance systems as a way to promote peace while managing the government from the capital city or to break unions that would oppose them (Eaton and Dickovick 2004). In the 1980s, international economists influenced by neo-liberalism and the Washington Consensus, defined by Williamson as engaging in a pro-market 
economy, viewed decentralization as a way to move from rent-seeking of the State to using a marketplace to make decisions in a more pluralistic fashion (Manor 1999; Williamson 1990) $)^{1}$.

Recent writing (Bahl and Johannes 1994; Campbell 2003; De Mello 2000; Montero and Samuels 2004; Rodden 2004; Rodriguez 1997; Rondinelli and Shabbir Cheema 1981) on fiscal decentralization has suggested that the process of decentralizing financial resources in Latin America-either by increasing revenue generation at the local level through incentives from the national government or expenditure decentralization by increasing transfers from the national government to lower levels of government-is incomplete for three reasons. First, some scholars (De Mello 2000; Rodden 2004) focused their research on moral hazard, which is the likelihood that municipalities borrow more money than they could pay back, forcing the national governments to bail them out and jeopardizing the state's macroeconomic stability. Second, Montero and Samuels (2004) and Eaton (2004) researched the problem of institutional power-similar to the mal-apportionment in the legislative bodies-creating disincentives for politicians to stay local, be faithful to their constituencies, and manage their own resources. Lastly, Campbell (2003) adds the public administration perspective. He identifies that this is difficult specifically because of weak political will and little administrative capacity.

First, Campbell (2003) suggests that local government have few incentives to raise their own revenues because often central governments subsidize programs through inter-governmental transfers and non-competitive grants. Second, newly elected mayors

\footnotetext{
${ }^{1}$ Neoliberalism is a market-driven approach to economics, based on neoclassical theories that stress the efficiency of private enterprise, liberalized trade and maximizing the role of the private sector. This was coined the Washington Consensus by Williamson in 1990.
} 
are often viewed as having minimal levels of education and therefore are unable to administer large amounts of capital. Third, the political cost of raising taxes is high and therefore difficult to reform. For example, in the case of Mexico democratization arrived late compared with Argentina. The central government strongly controlled state and municipal elections, which were almost totally rigged (Eaton and Dickovick 2004; Eaton 2002) and "absorbed" the political cost of raising taxes, considerably delaying the incentives of state and local governments to build revenue-raising capacities.

Arguably, the balancing of national priorities and local autonomy is a politically challenging task. In theory, to complete the process the central government would need to permit and incentivize the new entities the right to tax its population to pay for its own public programs. Academics suggest that this final element, setting up decentralized financial reforms, promoting fiscal incentives, and encouraging revenue systems to emerge from below, has proved to be very difficult to implement (Rondinelli and Shabbir Cheema 1981; Taliercio 2004; Falleti 2005). The next section looks at how these reforms have occurred in Latin America.

\subsection{Political Decentralization Perspective}

By the early 1980s, Latin American countries started to entrust more state functions to local governments. City officials would be responsible for direct public services, manage increased budgets and implement health and education programs. This was coupled with various democratization movements throughout the same period which encouraged the development and spread of local elections (Montero and Samuels 2004). Evaluations of decentralization policies increased after scholars saw several countries in Latin America return to democracy from authoritarian rule in the 1970s and 1980s 
(Bradhan and Mookherjee 1998; Escobar-Lemmon 2001; Fukasaku and Hausmann 1998; Grindle 2007; Hernandez-Trillo and Jarillo-Rabling 2002; Litvack and Seddon 1998; Martinez-Vazquez and McNab 1997; Prud'homme 1995; Rodriguez 1997; Rondinelli and Shabbir Cheema 1981). For example, Tulchin and Selee (2004) explain this relationship between decentralization and democracy by five conceptual reasons. The decentralization process served to improve the relationship between citizens and the state with measures to increase accountability, responsiveness, civic engagement, and pluralistic decision making, while counterweighing authoritarianism (Tulchin and Selee 2004). Arguably, the process could only earn legitimacy if subnational governments had sufficient autonomy to set their own priorities and had the capacity to perform the functions they determined themselves. Local governments became stronger in the 1990s when international advisors suggested certain social policies, in particular education and health care, could be implemented more efficiently by the decentralizing the process. Local governments became the launching ground for implementation because in theory local administrators were able to reach the poor directly (Kaufman and Nelson 2004).

Researchers have focused their writings on the political system and the lasting effects of local politics within the region (Benton 2001; Grindle 2000; Grindle 1996; Rodriguez 1997; Selee 2006). For example, subnational establishments became strengthened with new authority, which subsequently created a change of power between political parties (Benton 2001). The most cited example is Mexico in the 1980s and 1990s, with the increasing importance of local politics that helped the National Action Party (Partido Acción Nacional-PAN) win state elections ending the one party rule of the Institutional Revolutionary Party (Partido Revolucionario Institucional-PRI) with 
PANista Vicente Fox winning the 2000 presidential election (Alesina, Hausmann, Hommes, and Stein 1999; Diaz-Cayeros 2006; Merino Huerta 1991; Merino Huerta 2008; Rodriguez 1997; Tulchin and Selee 2004).

Although the decentralization movement began as early as the 1970s among nongovernmental organizations (NGOs), which wanted to decentralize not only to local governments but also to provide increase revenues to their organizations. Many human rights advocates and grassroots leaders aggressively called for state autonomy and local management of public resources. Often these groups received financial aid from international development organizations and donors who felt their money was better spent assisting local groups (Bates and Daubon 2007; Breslin 1987; Hirschman 1970).

As a corollary to these decentralization efforts, international financial institutions (IFIs) such as the World Bank and the Inter-American Development Bank (IADB) advocated public-private partnerships (PPPs) in the 1980s. These partnerships were viewed as the best way to treat the lack of resource problem at the local level, especially after several countries enacted austerity measures in their economic policies. The political and administrative decentralization processes had taken place in many parts of Latin America, but countless fiscal reforms still remained to be made for many countries. Many cities and smaller municipalities in the region scrambled to find resources. Agreements between NGOs, the county or city governments were matched by national program dollars. These social programs, whether they were micro credit, school programs or health services, still only enabled aid to reach a small selected portion of the population (Tendler 1997). Often these public-private partnerships were matched by international dollars, thereby supporting the "private portion" of the agreement because the local 
government counterparts did not have sufficient funds to match private investment in the manner that occurred in the United States.

The 1990s literature framed decentralization as creating good governance, active decision-making and local control while increasing citizen participation (de la Maza and Villar 2005). Civil society groups promoted civic participation, which was adopted by the international system as an idea of how to assist the poor (Narayan and Patesch 2002). For example, the process of decentralization led to innovations at the local level such as participatory budgeting practices, civic round tables, open space debates, and the increase use of referendums (de la Maza and Villar 2005; Hirschman 1970; Smith 2009b). Although there were laws and ordinances instructing cities to make local development plans and implement participatory budgeting, they often lacked sufficient capacity and financial autonomy to perform their jobs efficiently.

\subsection{Administrative Decentralization Perspective}

After neo-liberal reforms of the 1980s left severe impacts on the social sectors of Latin America, economists developed welfare programs to reach the poorest of the poor (Levy 2008a). In the late 1990s, IFIs purposed redistribution programs to be implemented at the local level by providing direct subsidies to the beneficiaries. Social programs, primarily in health and education, started to spring up across the hemisphere such as former-Progreso and now Oportunidades in Mexico, Jefes de Hogar in Argentina, Unidos in Peru, and Fame Zero (zero hunger) in Brazil (Kaufman and Nelson 2004; Levy 2008a). ${ }^{2}$ Several academics call the devolution of public policies from national ministries to local governments referred to as administrative decentralization (Brachet-Marquez

\footnotetext{
2 Researchers are now calling the new social programs the second-generation reforms of the Washington Consensus.
} 
2002; Falleti 2010; Gibson 2004; Lora 2008; Rondinelli and Shabbir Cheema 1981; Stein, Tommasi, Echebarria, Lora, and Payne 2006). Because the distribution programs for health, education and social policies at the local level have emerged, so have evaluations to measure their effectiveness (Merino Huerta 2008).

In the early 2000s, Washington saw a large number of these policy evaluations (Andrews 2008; Beck Fenwick 2007; Kaufman and Nelson 2004; Levy 2008b; Levy and Walton 2009). Many evaluated whether the programs were working and providing positive impacts on professional development of the poor. Evaluations were concerned with who was receiving the financial rewards, how the policies were implemented, and if the programs were effective. Often these assistance programs' were tied together. Children would be mandated to attend school and visit the doctor for regular checkups before families received their financial assistance, either with vouchers or direct financial assistance (Levy 2008b). Once there were fairly positive results in one country, additional countries were also encouraged to provide similar subsidy programs.

The process created an influx of national dollars to be redistributed to individuals through direct transfers. Instead of transforming state public health or education ministries, many countries used their local governments to distribute funding to program participants. Beck Fenwick's (2007) research highlights the new role local government's gained in the delivery of social policies in Argentina and Brazil. She concluded that Brazil had better outcomes in terms of providing public services to citizens than Argentina due to the inter-governmental cooperation and the local government's autonomy. Her research found that it was the nature of the party system and the constitutional status of the local governments, which matter the most for the poor to 
receive public services. These social policies not only re-emphasized the role that local governments provide, but also the administrative burden added to them.

Kaufman and Nelson (2004) evaluate how social sector reforms are occurring in Latin America by comparing education and health care programs in six countries. They claim that democratization and globalization forced more governments to clearly define social priorities, but the political process of reform is difficult. Kaufman and Nelson (2004) argue that IFIs frequently suggest to governments that it is just as important how money is spent for these services as how much (emphasis added in original). For these authors, municipal governments are proving to have a vital role in the provision of services. Municipal officials could assist in improving the quality of the social services and also the efficiency and cost-effectiveness of the program design. For example, the authors argue that the social policy reforms have "derailed the complex administrative machinery" with new lines of authority of local governments at the forefront in service delivery (Kaufman and Nelson 2004). They agreed that decentralization, with increases in civic participation, could assist with the social sector reforms.

Andrews (2008) in her work on Brazil defines the devolution of health, education and social policies as "deconcentration" and not further decentralization. She highlights that the administrative systems should be seen as managing an effective partnership between the federal and municipal level governments. With decentralization, poor municipalities became reliant on the federal government to increase local revenues, implement these pro-poor policies and sustain themselves (Andrews 2008). Therefore, the poorer municipalities are the least likely to promote decentralization policies, but prefer to enjoy the benefits of the national government deconcentration. Richer 
municipalities also provide services such as health assistance programs with the help of the national government. She concluded that a country with a greater percentage of poorer municipalities would encourage a greater shift towards centralization. For her, wealthy municipalities are more likely to promote decentralization than poorer. As in the United States, there is a desire to keep own-source revenue at home to improve local policies and therefore have strong decentralized national policies.

The administrative decentralization debate highlights the need for national governments to think of the appropriate level of government structure to manage the implementation and funding of social programs. Arguably, there are large variations in the data across countries, but researchers can evaluate where the indigent populations live, enabling policy makers to better target programs. As a results of the local government's limited ability to raise taxes, the appropriate mixture of market-based incentives are difficult to establish and the fewer public goods that can be produced. This and the state of fiscal decentralization are described in the next section.

\subsection{Fiscal Decentralization Perspective}

Current scholarship is focusing particular attention on the fiscal aspects of decentralization and federalism (Abuelafia, Berensztein, Broun, and Di Gresia 2004; Eaton 2001; Eaton and Dickovick 2004; Grindle 2007; Haggard and Webb 2004; Montero 2001; Stein 1999a; Tommasi 2002; Tommasi, Saiegh, and Sanguinetti 2001; Willis 1999). Whereas fiscal decentralization involves the devolution of financial recourses from the national government to lower level governments, fiscal federalism is managing the contentious relationship of budget constraints at various levels of government. Fiscal federalism theory suggests that determining the appropriate 
relationship between national appropriations and the revenue generated locally will produce the most effective public policies (Tanzi 2000; Tommasi 2002).

Economists suggest there have been two major trends of fiscal federalism (Bahl and Johannes 1994; Tanzi 2000; Tommasi 2002; Weingast 1995; Wibbels 2005). Wiesner (2003) suggests the first generation of reforms began in the early 1980s with the Washington Consensus. The changes included constitutional reforms to allow local elections, devolving electoral responsibility; delegating taxing and spending authority; and encouraging results based budgeting by local governments. Wiesner includes in this first generation of reforms targeted fiscal transfers by sector (primarily in education and health) to assist the lowest income groups. For Wiesner, these targeted fiscal transfer and conditional welfare policies, with the exception of Chile, were flawed in terms of making systematic reforms.

According to Wiesner, many national governments did not have sufficient understanding of the potential risks caused by public choice theory and did not provide adequate support and training for local governments to manage their resources. This caused IFIs to provide more loans to national governments in order to bailout the subnational level, which took out too much debt in times of need. For example, see the bailout case of the Mexican peso crisis in 1994 or the Argentine economic collapse of 2001. While praising the concept of market-based incentives for reforms as performed in Chile, economists now promote "the second generation" of decentralization reforms (Tommasi 2002; Weingast 1995; Wibbels 2005). These scholars suggest that national governments can produce a more appropriate mix of market-based incentives. 
Scholars argue that this "second generation," still incipient, began in the late 1990s in Latin America (Tommasi 2002; Weingast 1995; Wibbels 2005). The basic idea is based on three theoretical constructs: new institutional economics, public choice theory and the new theory of the firm. Although evaluations still need to be produced on the social and firm costs to any particular policy, this general application of microeconomics into public policy in the context of decentralization may be useful. Insomuch as Wiesner (2003) highlights policies can be implemented at different levels of government, he suggests that it is the national government that should stabilize the macroeconomic indicators of a country in order for subnational governments to engage in micro-level policies like economic development.

One basic criticism of fiscal federalism is that it should be distinctive from fiscal decentralization - or granting the tax authority at the local level. Academics warn that fiscal federalism should not be confused with fiscal decentralization, but some do intermingle the concepts. The Organization for Economic Cooperation and Development (OECD) defines fiscal federalism as "a system of transfer payments or grants by which a federal government shares its revenues with lower levels of government" (OECD 2007). Oates (1999) definition adds that fiscal decentralization is a "general normative framework for assignment of functions to the different levels of government and appropriate fiscal instruments for carrying out these functions" (Oates 1999). Both have highlighted the important role for local governments and have increased their local budgets, but arguably national government policies and legal frameworks still do not encourage local governments to raise sufficient revenues. Whereas fiscal federalism involves the management of budget constraints and allocation of public finance at all 
levels, fiscal decentralization encourages local citizens to collect their own resources. Arguably, only fiscal decentralization (conceptualized as municipal governments allowed to raise and to collect their own tax revenue) helps citizens to manage their own initiatives, which is the key for local economic development.

\subsection{Public Finance Perspective}

There are at least three ways to evaluate fiscal decentralization: local tax collection efforts, expenditures of local governments and fiscal federalism, or the balance of the collection and revenue system at the various levels of government. Rosenbaum (1997) suggested that before other regions of the world, Latin America "witnessed the emergence of issues of fiscal decentralization - especially in terms of revenue sharing, national grants in aid and various types of privatization" (Rosenbaum 1997:13). Academics typically cite the level of decentralization as the amount of subnational expenditures (Bahl and Johannes 1994; De Mello 2001; Ebel and Yilmaz 2002; Gemmell, Kneller, and Sanz 2009; Martinez-Vazquez and McNab 1997; Stein 1999a).

Figures 2.1 and 2.2 provide an overview of subnational revenues and expenditures from 1997-2006. What can be drawn from these figures is the wide range of decentralization that has occurred within the region. One can see that the federalist countries of Brazil and Argentina are far more advanced at decentralizing revenues and expenditure than unitary countries such as Costa Rica and Paraguay. Moreover, subnational expenditures have increased more than revenues. Scholars suggest that this is because of administrative decentralization with local governments implementing major social policies (Andrews 2008; Kaufman and Nelson 2004; Tulchin and Selee 2004). 
Figure 2.1 Latin American Subnational Revenues as percentage of GDP 1997-2006

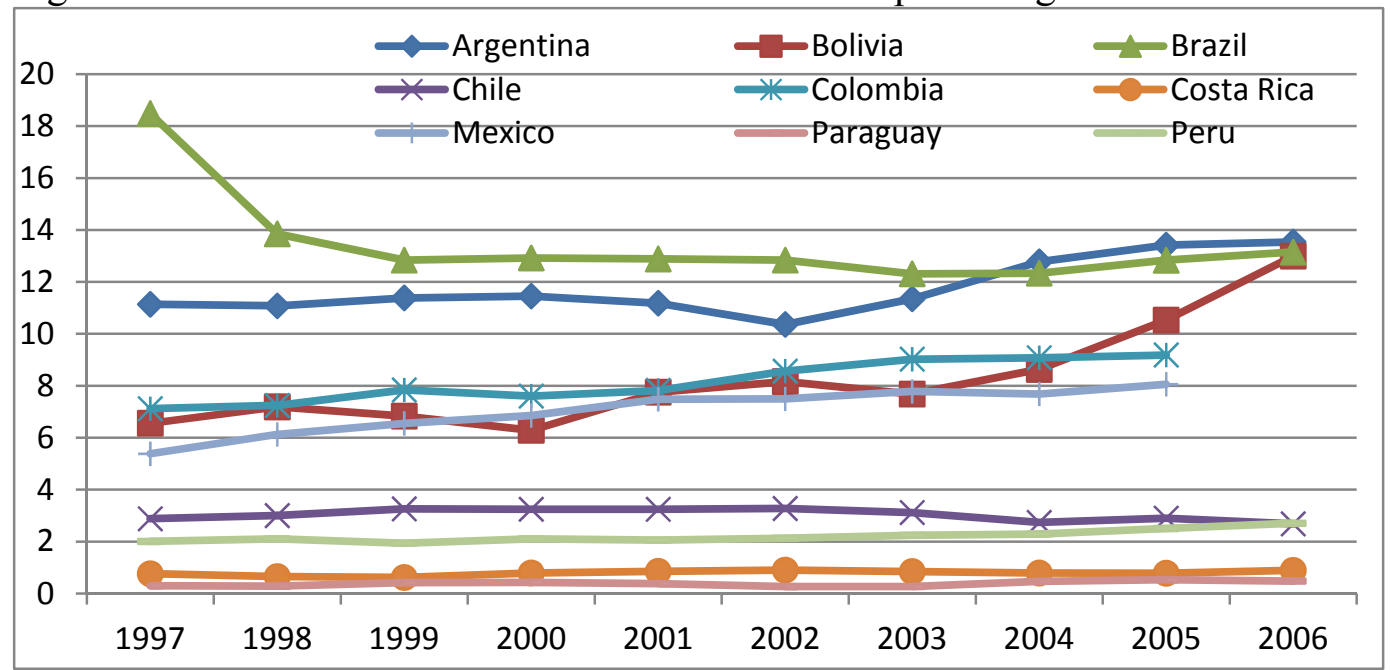

Source: UN's Economic Commission for Latin American (ECLAC).

Figure 2.2 Latin American Subnational Expenditures as percentage of GDP 1997-2006

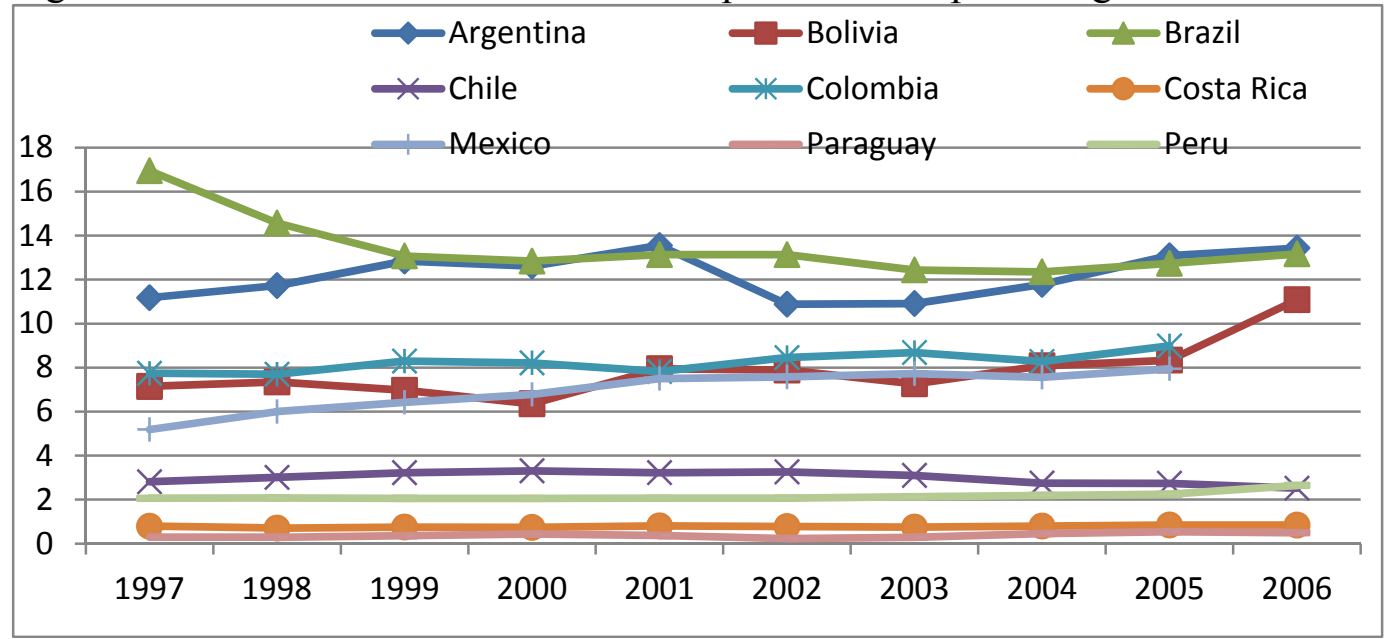

Source: UN's Economic Commission for Latin American (ECLAC)

The public finance literature suggests that it is much harder to encourage local governments to collect revenue than to decentralize budgetary expenditure. For a long time, researchers focused less on how taxes were generated (VAT, sales, property, income tax) and at what level, and more on recommendations on how to implement programs and spend funds (Benton 2001; Bird 1992b; Bird and Oliver 1968; Bird 1992c). Arguably at the same time, there has not been sufficient focus in the literature on how to 
generate the most appropriate, market-oriented driven, fiscal policy that encourages collecting taxes at the local level. Figure 2.3 shows the total tax revenues as a percentage of GDP for six countries in Latin America.

Figure 2.3 Latin American Overall Tax Revenues as percentage of GDP 1990 - 2008

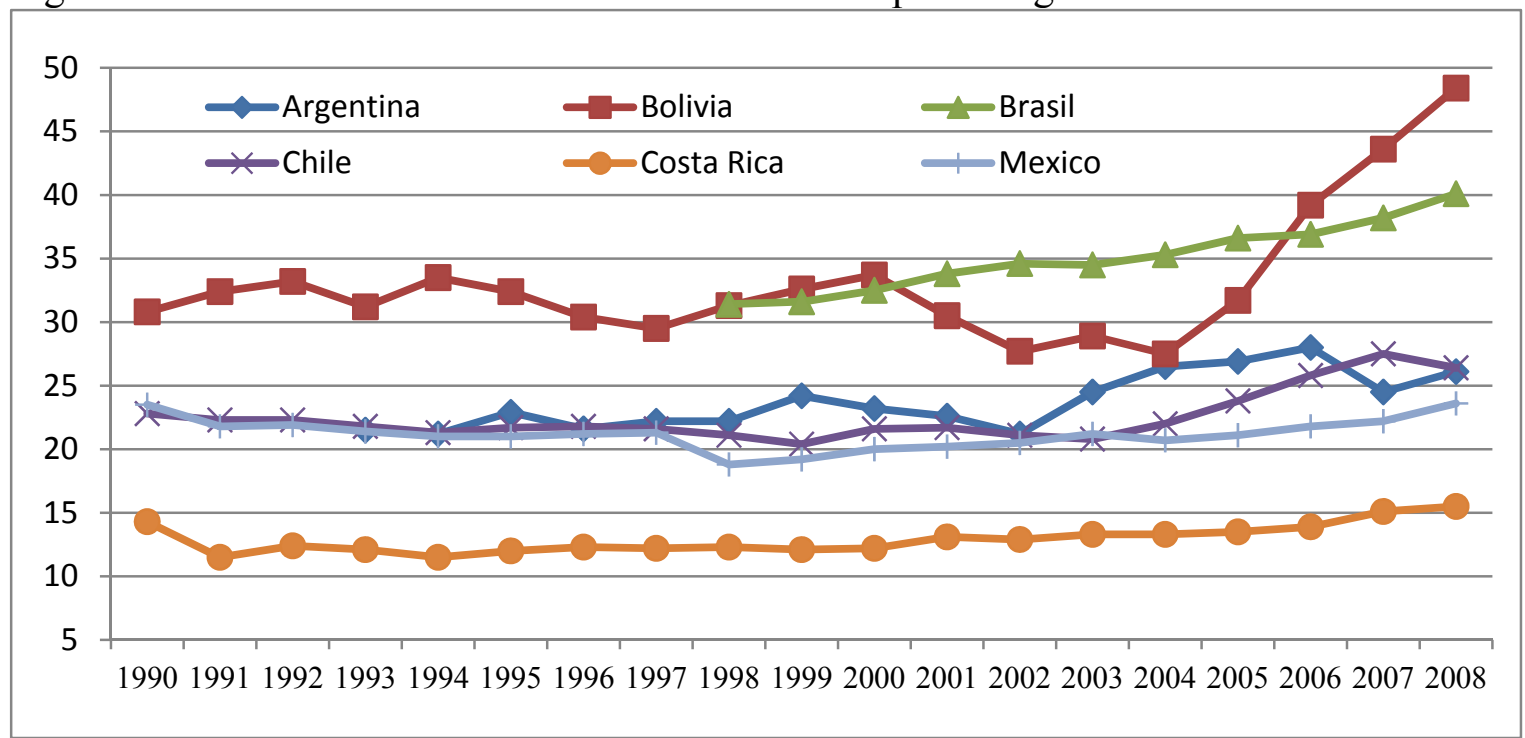

Source: Latin American and Caribbean Macro Watch Data Output, Inter-American Development Bank.

Scholars suggest that tax revenues in Latin America are low by international standards (Bahl and Bird 2008; Bird and Oliver 1968; Mahon 1997; Mahon 2009). The Inter-American Development Bank (IDB) reports that tax revenues in the region as a whole, excluding social contributions, were about 17 percent on average of GDP in 2005. Large discrepancies in tax burdens exist across countries and within states (at the subnational level). They range from the low burdens of countries endowed with nonrenewable resources such as Mexico and Venezuela (which are around ten percent of GDP) to higher tax levels such as in Brazil (which is around 36 percent of GDP). Whereas Brazil is one of the most progressive and decentralized systems where local governments do collect the highest amounts of taxes within the region (de Mello 2009). 
Figure 2.4 Total Tax Revenue as a Percent GDP Compared

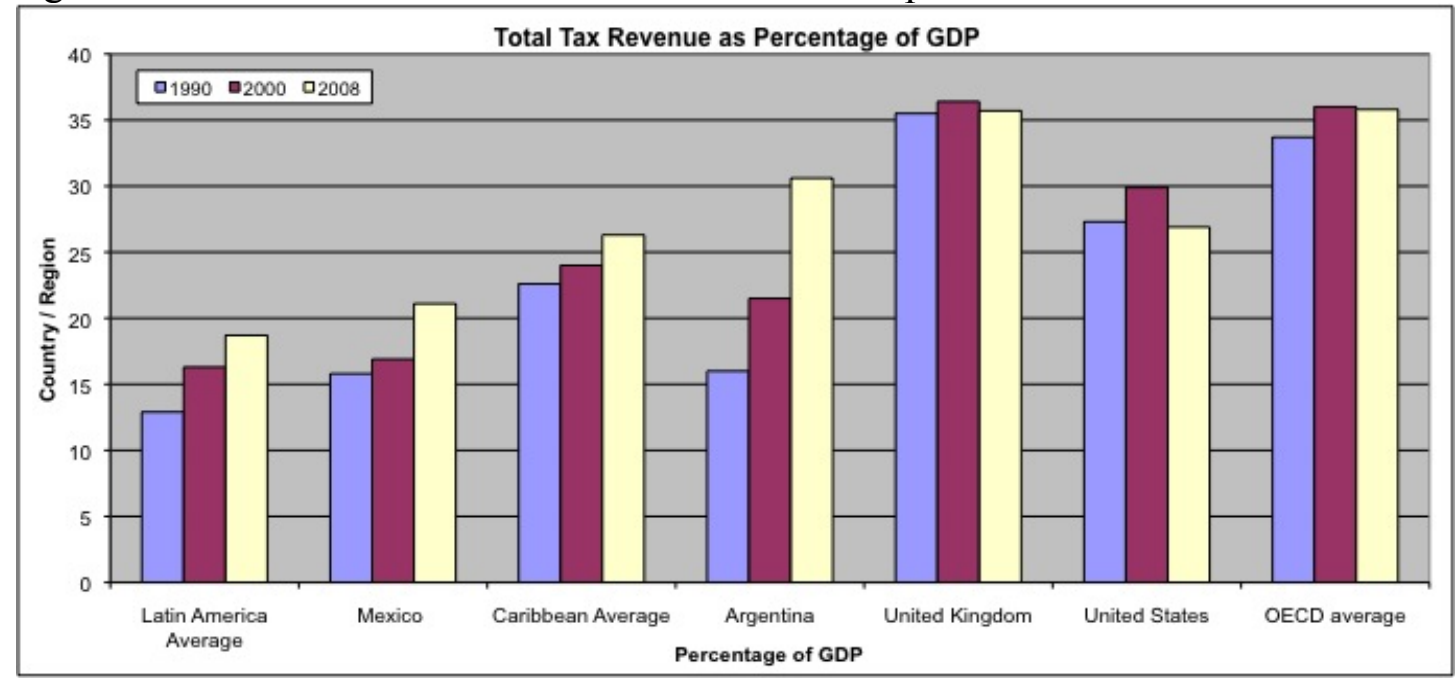

Sources: Data for Mexico, United Kingdom, and United States comes from OECD. Data for Argentina, Latin America and the Caribbean comes from Economic Commission for Latin America and the Caribbean (ECLAC).

Figure 2.4 indicates that Argentina's tax-to-GDP ratio reached 31 percent of GDP in 2008, which is closer to the OECD average and higher than many of the other Latin American countries. But in some countries, such as Peru or Mexico, government revenue is much lower, usually in a range of 11-20 percent of GDP. This reflects the inability of the government to bring more dynamic sectors of the economy into the tax net, or rates are low, or evasion is high, or all three.

Recent studies have shown that taxation at the local level also varies a great deal within the region (Falleti 2005; Finot 2001; Wiesner 2003). Wiener (2003) cites that Chile does not allow for much local taxation-less than 0.6 percent of GDP. Brazil manages a varied hierarchical tax base structure where the sub-national governments (states) manage up to 30 percent of GDP in some locations. The function of the national government is to find the appropriate balance of the fiscal capture and dissemination of funds to be more equitable across sub-national boundaries. At present, fiscal decentralization in Latin America has called attention to the financial discrepancies 
between jurisdictions, which have created large fiscal gaps for many state economies. For example Falleti (2004) points out that Buenos Aires raises 92.7 percent of its own revenues and the Province of Buenos Aries generates 56.1 percent, while other locations such as Catamarca, La Rioja and Santiago del Estero raise about 11-15 percent of their own revenue. These inter-jurisdictional inconsistencies also exist in Brazil, Bolivia and Mexico (Wiesner 2003).

Despite these internal country differences, there are a number of common weaknesses in the tax systems across the region. First, there is heavy reliance on indirect and payroll taxes — representing about 75 percent of the total — that results in a regressive tax system. While in developed countries the tax system helps to reduce inequality, in Latin America it exacerbates it (Gomez Sabaini 2006). Evidence suggest that Latin American countries have a high dependency on indirect taxes such as sales tax, goods and services tax (GST), and value-added taxes (VAT), which are collected by intermediaries, i.e. a retail stores, and not from the person who ultimately carries the economic burden of the tax. These taxes make consumers not "feel the cost" of the tax for the goods which they are purchasing (Bahl and Bird 2008; Bird 1992b; Bird and Oliver 1968; Di John 2006; Joyce and Mullins 1991; Koethenbuerger 2007; MartinezVazquez 2008; Moore 2007; Schumpeter 1918; Schumpeter 1948; Tanzi 1969).

Second, the tax system in Latin America does not appear to be determined by equity or efficiency criteria (i.e. the collection of point of origin or the increase of personal income and property taxes to broaden the tax base). According to data from the World Bank's Doing Business Report (2009), tax rates for small businesses in Latin America are higher than in several other regions (World Bank 2009). In particular, taxes 
on profits are on average the second highest after Sub-Saharan Africa. When efficiency concerns over the type of taxes to be implemented, economics encourage the use of VAT (Bahl and Bird 2008; Bird 1992a; Bird and Oliver 1968; Bird 1992c; Birdsall, De La Torre, and Menezes 2007). Arguably, by simplifying tax regimes, such as reducing the hurdles and the time required to comply with bureaucratic procedures, are still milder steps to encourage better tax administrations.

Another challenge is to broaden the tax bases in order to reduce the reliance on distorting taxes. For example, the resource rich countries with oil, such as Mexico, Venezuela, Peru need to diversity their tax base away from this finite resource (FarfánMares 2010). This is not only because they need more resources to pay for public goods, but to also to encourage the state building processes, which allows citizen to rely on the governance system. Scholars suggest that institutional development, such as decentralization and encouraging a wider tax base, is essential for Latin American governments to be stronger in the future (Bahl and Bird 2008; Bird 1992b; Di John 2006).

Latin American countries' ability to collect taxes, or their fiscal capture, is often lost to capital flight because individuals who earn higher salaries simply save it in foreign banks to avoid income, payroll and social security taxes. The loss of savings within domestic banks also creates disincentives for investments within the region. The combination of low tax revenues and high tax rates points to the high incidence of tax evasion, which can be for large corporation as well as smaller and medium enterprises. Studies (Kapstein 1994; World Bank 2009) have focused on micro-enterprises and their effective tax rate and have found it to be the largest sector to evade taxes. For instance, 
numerous tax exemptions (especially for the VAT) and various taxes on financial transactions are commonplace.

In general, the public finance literature for developing countries offers a variety of policy options to seek more efficient and equitable ways to tax (Bahl and Bird 2008; Bird 1992b; Bird and Oliver 1968; Di John 2006; Joyce and Mullins 1991; Koethenbuerger 2007; Martinez-Vazquez 2008; Moore 2007; Schumpeter 1918; Schumpeter 1948; Tanzi 1969). For example, Bahl and Bird (2008) suggest countries should simplify and broaden tax bases, lower income and corporate taxes (in order to encourage business development), and promote reductions in trade tax rates through trade liberalization. Property and income taxes are generally encouraged within more developed economies because they are more progressive taxes and harder to implement with efficient administrations (Martinez-Vazquez 2008; Moore 2007). Campbell (2003) argues that the administrative capacity of governments to collect taxes is weak and ineffective. He discusses key variables when proposing progressive tax reforms: the administrative burden and political will for reforms.

Economists (Bahl and Bird 2008; Martinez-Vazquez 2008; Moore 2007; Campbell 2003) agree that administration reforms - the management and collection of taxes - are as important, if not more, than the kind of taxes (VAT, sale, personal income, property, social security) that a country chooses to collect. Arguably, it is as important to have sound enforcement mechanisms and an independent administration to manage, collect and distribute public goods. Based on the literature, revenue collection authorities are more effective when they operate autonomously from the federal government (i.e. outside the national finance ministries). This last point could lead to a role for local 
governments to increase tax collections. Therefore, this research helps to contribute to the gap in the literature on how local governments can be effectively used to leverage additional public finances. This research tests the capacities of local governments to collect and manage local resources for development outcomes. The theory of local economic development is described in the next section.

\subsection{Local Economic Development Theory}

In general, mainstream economic development research has focused on the role of small and medium enterprises (SMEs) as a bottom-up strategy for developing Latin American economies. This literature suggests that new firm creation is one way to advance growth that encourages the strengthening of a middle class, provides equity between classes, and helps to maintain a healthy and peacefully stabile society (Cabrero 2000; Malizia and Feser 1999). Although research has focused on SMEs effects on development, little attention has been given to the policy role for municipalities to assist in their creation. For example, a study done by Kuwayama et al. (2005) cites that according to available data from 17 Latin American countries micro, small, and mediumsized enterprises make up 77 percent of employment in the region and nearly 65 percent of this proportion are micro-enterprises, measured as having five or fewer employees (Kuwayama, Yasushi, and Tsuji 2005).

International donors also have advocated the support for SMEs to accelerate economic development. For example, between 1998 and 2002 the World Bank provided more than $\$ 10$ billion and the United States provided an additional \$1.3 billion in 2003 alone for SME support programs (Juckett 2008). Such policies and programs encourage competition, entrepreneurship and have the potential to add jobs to the economy (Beck et 
al. 2005). Problems may arise if this aid is not targeted into specific geographical areas, then it could be unable to make significant headway into promoting development and eliminating inequality within a specific region.

The World Bank has offered another possible solution: local economic development (LED), which it defines as the building-up of the economic capacity of a local area to improve its economic future and the quality of life (World Bank 2008). "The term economic development is often used to refer to what is essentially land development or physical development," but it can also be used in a larger policy context that directly helps to increase income or employment for its residents (Wolman and Spitzley 1996:116). Conceptually, for the present study should not be confused development with growth. Rather this dissertation examines specific actions that a local government can do to improve local business investment climate, which is a form of economic development Programs areas to implement LED strategies may include items such as "investments in soft infrastructure and local business growth, encouraging new enterprises, promoting inward investments, sector (and business cluster) development, area targeting/regeneration, integrating low-income or hard-to-employ workers" (World Bank 2007).

Blakely and Bradshaw have suggested "local economic development (LED) is an emerging field, and currently more of a movement rather than a strict model specifying a uniform approach" (2002:55). Local economic development incorporates neoclassical theories of economics with economic base theory, to evaluate the flow of economic activity in and out of a physical area. For these authors, local and regional development 
equals an area's capacity (which measured in economic fiscal, technological and political terms) multiplied by its physical resources (Blakely and Bradshaw 2002).

Malizia and Feser emphasize that LED originated from the 1990s literature, which incorporated social theories of how human interactions help facilitate economic development. For these authors, the empowerment of these social forces is important for understanding how citizens exercise their decisions within the development process. They suggest that these behaviors described at the firm or industry level can shape a city's competitive advantage (Malizia and Feser 1999). Entrepreneurship theory, a key component for economic development, highlights individuals as the first to respond to market pressures. Under this view, they are the "visionary who attempts to marshal resources in unique ways to bring new ideas for products or services to economic fruition" (Malizia and Feser 1999:195). Studies of entrepreneurship have often been synonymous with small business development and the effort for entrepreneurs to create small businesses demonstrates a tangible measure for their success.

According to Malizia and Feser (1999) research on entrepreneurship has been divided into studies of external factors for economic growth and change, while others focus on internal factors that promote entrepreneurial behavior and motivation. The former is factor of interest for this study. Environmental factors are expected to be particularly important here as well due to the role that local governments play in assisting to help promote economic development. For example, Bruno and Tyebjee (1982) suggest that there are twelve factors for a location to support entrepreneurs. In their list, favorable government politics is relevant here (Bruno and Tyebjee 1982). ${ }^{3}$ Yet, these authors argue

\footnotetext{
3 The other factors include venture capital availability, presence of experienced entrepreneurs, technically skilled labor force, accessibility of suppliers, accessibility of customer or new markets, proximity of
} 
that more research is needed to understand how to manage and foster the enabling environment by local government officials.

In their research, Pagano and Bowman (1995) find those factors which are most important for city governments to promote economic development in the United States. For them, "the [most] critical element in transforming the extant urban landscape into the cityscape of tomorrow are twofold: 1) vision of a city's leaders, their determination and commitment to pursue their vision, their capacity to mobilize public capital for the attainment of the vision and 2) the strengths, diversity and resiliency of the local economic base" (Pagano and Bowman 1995):137). These authors conclude by suggesting the following policy advice:

However, while city government control land (or space); it has little control over labor or capital. It is this interaction of politics and economics that produces cityscapes of the next millennium. These elements determine whether a city is survivalist, expansionist, maintenance, or market oriented (Pagano and Bowman 1995:137).

Since it is the government that is able to promote or change these environmental factors, this dissertation evaluates the administrative structure (i.e. level of fiscal decentralization) of Latin American countries in their efforts to promote local economic development as a way to encourage small business entrepreneurship. Local governments need to be involved and, may be better equipped than centralized governments, to provide this essential favorable policy environment. Efforts starting in the 1980s by many Latin American governments to decentralize could provide some indicators as to how to create these favorable policy environments at the local level. Yet, a little unknown fact is that LED theory has been studied and applied in Latin America for the last decade to spur

universities, availability of land or facilities, access to transportation, receptive populations, availability of supporting services, and attractive living conditions. 
growth in regional areas and can be traced by projects, research and funding located within the region (Albuquerque 2004; Alburquerque 1999; Arocena 1998; Benavides and Manrique 2000; Boisier 2004; Cabrero 2000; Coelho 2000; Costamagna 2000; Cravacuore 2002; Gallicchio and Winchester 2003; Marsiglia and Pintos 1999; Vázquez Barquero 2000; Vázquez Barquero 1999; Vázquez Barquero 2000; Ziccardi 1998).

Within the region, Albuquerque (2004) was among the first to describe LED theory and how it relates to decentralization policies in Latin America. He incorporated Porter's "clusters" with Kliksberg's explications of social capital to describe how industrial development and economic development could be induced within a particular urban space (Kliksberg 2004; Kliksberg 2005; Porter 1990). Within Uruguay, Arocena (1998) and Marsiglia and Pintos (1999) further theorized on how local economic development could help countries in Latin America by critiquing several approaches applied in developed countries. Boisier $(1998,2001)$ described geographical place based on approaches of LED and used case examples from his native Brazil. Cabrero (2000) and Zaccardi (1998) used LED theories to inspire Mexican communities to direct their own development.

In later work, Albuquerque (2004) outlined several scholars who worked directly with programs that promoted LED. For example, Coelho's (2000) work analyzed the planning efforts of the Rio Braco and the municipalities around the Valle Medio Paraiba region in the state of Rio de Janeiro. Benavides and Manrique (2000) study of the Villa El Salvador, a poor suburban area of Lima, which constructed housing and urban infrastructure that became a best practice for LED in the region. Caceres and Figueroa (2000) evaluated the effectiveness of Chile's National Solidarity Fund for Social 
Inclusion (FOSIS) in building social capital and local investment. Gallicchio and Winchester (2003) wrote a book on the local development experiences of their native Uruguay and Chile (respectively), and describe the successes and failures of several communities as they attempted to implement these theories. Costamagna (2002) described Rafaela's efforts to consolidate development between public and private sectors in the province of Santa Fe, Argentina. Finally, Cravacuore (2002) created a collection of research on LED activities in Argentina. Nearly all research on LED in Latin America uses qualitative analysis or provides impact evaluations on a specific location. Few studies use quantitative analysis to understand how local public officials are engaging in LED. This dissertation looks at the structure of governments, measured by fiscal decentralization, in an effort to understand how local governments are promoting LED programs as a way to encourage economic development.

\subsection{Empirical Evidence}

Several large-scale quantitative research studies have found a mix of results as to the effects of fiscal decentralization on economic development. For example, Glaeser et al. (1995) found a positive association between local public sector investment and a city's economic growth in the United States by using panel data of 260 cases (Glaeser, Scheinkman, and Shleifer 1995). Scholars using a similar quantitative model to evaluate growth in developing countries found no casual links (Davoodi 1998). Rodden's (2003) studied tax competition between subnational governments, by using data from both developed and developing countries, and found it limits growth. Another study of 15 Latin American countries concluded that fiscal federalism with wide-ranging autonomy can create overall fiscal deficits, but lowers inflation rates (Rodden 2002). De Mello's 
(2008) study of Brazilian municipalities found public financing and government spending impact the growth of an area's population. The author found that urban growth and municipal populations are positively affected by the increased provision of public goods and services that a local government can provide.

Scholars explain the mixture of outcomes by the variation that exists in terms of measures of autonomy, fiscal decentralization and own-source revenue generation (Ebel and Yilmaz 2002; Gemmell, Kneller, and Sanz 2009; Liu 2007; Martinez-Vazquez and McNab 1997; Rodden 2004). The differences can be conceptual, such as how autonomy is defined, to more tangible, such as how budgets are calculated and organized. For example, each country counts its income and expenditure statistics differently and this may create discrepancies in the data. To explain this, Ebal and Yilma replicate Davoodi and Zou's and de Mello's earlier studies on tax autonomy, economic stability, economic growth and total size of the public sector and provide different outcomes depending on the definition of local autonomy.

Most econometric studies only use macroeconomic statistical models without evaluating how municipal governments are spending and collecting their resources on the ground. Many of these studies use the Government Finance Statistics (GFS) of the International Monetary Fund (IMF) or the OECD data to measure decentralization, of which both maintain multi-country databases over a large time series. For example, the OECD data are from 1971-2005 and include most of the major economies in the world (Gemmell et al 2009). Neither the GFS indicators nor the OECD data include information at the municipal level of government; rather their datasets combine both state level and 
municipal data and call the variable subnational. More specific definitions and additional data sets are needed to better understand these effects.

\begin{tabular}{|l|l|l|l|}
\hline \multicolumn{4}{|l|}{ Table 2.1 A Summary of Quantitative Research } \\
\hline Author & Year & Method & Findings \\
\hline Glaeser et al. & 1995 & $\begin{array}{l}\text { They used panel data of 260 } \\
\text { cases in the United States. }\end{array}$ & $\begin{array}{l}\text { They found a positive } \\
\text { association between public } \\
\text { sector investment and a city's } \\
\text { economic growth. }\end{array}$ \\
\hline $\begin{array}{l}\text { Davoodi and } \\
\text { Zou }\end{array}$ & 1997 & $\begin{array}{l}\text { They evaluated growth in } \\
\text { developing countries. }\end{array}$ & They found no casual links \\
\hline Rodden & 2003 & $\begin{array}{l}\text { They study the tax competition } \\
\text { between subnational } \\
\text { governments. }\end{array}$ & $\begin{array}{l}\text { He found tax competition } \\
\text { limits municipal growth. }\end{array}$ \\
\hline $\begin{array}{l}\text { Rodden and } \\
\text { Wibbels }\end{array}$ & 2002 & $\begin{array}{l}\text { They used 15 LAC to study } \\
\text { fiscal decentralization and its } \\
\text { effects on municipal budget } \\
\text { deficits and inflation rates. }\end{array}$ & $\begin{array}{l}\text { They concluded that fiscal } \\
\text { federalism with wide-ranging } \\
\text { autonomy can create overall } \\
\text { fiscal deficits but lowers } \\
\text { inflation rates }\end{array}$ \\
\hline de Mello & 2008 & $\begin{array}{l}\text { He studied Brazilian } \\
\text { municipalities as a single case } \\
\text { study analysis. }\end{array}$ & $\begin{array}{l}\text { He found public financing and } \\
\text { government spending impacts } \\
\text { the growth of an area's } \\
\text { population. }\end{array}$ \\
\hline $\begin{array}{l}\text { Gemmell et } \\
\text { al. }\end{array}$ & 2009 & $\begin{array}{l}\text { OECD data is from 1971-2005 } \\
\text { and includes most of the major } \\
\text { economies in the world. }\end{array}$ & $\begin{array}{l}\text { They find distortionary } \\
\text { taxation reduces growth and } \\
\text { productive government } \\
\text { expenditure enhances growth. }\end{array}$ \\
\hline
\end{tabular}

For example, Oates (1999) evaluates the appropriate fiscal equation that is needed for economic growth. He appraises the Leviathan theory, which is the increase of subnational governments will increase the size of the entire government and therefore affect its influence over the economy (Oates 1999). In the Oates model, the dependent variable is the public sector size measured as total aggregate government current expenditure as a share of GDP. In his model, two proxies for decentralization were used: revenue share and expenditure share. The dependent variables used to understand capacity include the total government share of GDP (consumption plus investment, transfers excluded) and government consumption as a percentage of GDP. Government 
consumption measures spending on current operations and may be dominated by the government wage bill. ${ }^{4}$

In general, more recent analyses of fiscal decentralization have focused on subnational expenditures and not calculated revenue generation, which is important when analyzing fiscal autonomy (Martinez-Vazquez and McNab 1997, Ebal and Yilma 2002). To remedy this gap in the literature, additional measures of decentralization have recently been purposed (Gemmell et al 2009, Blume and Voigt 2008). For example, "revenue autonomy" is defined as the ratio of subnational government's own-source revenue over its total revenue. Own-source revenue is the sum of tax autonomy, figured by non-tax autonomy minus intergovernmental grants (this is the measure used here). Subnational revenues are a combination of taxes, transfers, grants, and loans. While local taxes offer the greatest degree of autonomy, grants and loans offer somewhat less, and discretionary transfers probably the least. That is because transfers, even supposedly automatic transfers from the national to the subnational government, can be withheld and grants and loans generally arrive with conditions or with expenditures earmarked (Schneider 2003).

Measuring revenues not accounted for by inter-governmental transfers could create some drawbacks. Therefore some authors encourage researcher to distinguish between the types of transfers. For example, whereas some transfers such as block grants, local government have more control over how they allocate the resources, others are tied to central government priorities and have earmarks, and still others require certain behaviors so that subnational governments must match the funds with local revenue. Still, the treatment of all revenues aside from transfers gives an indication of the degree to

\footnotetext{
4 Wage bill is a usual indicator of the economic "footprint" of government (e.g., Garrett 1998; Rodrik 1998; Barro 2000).
} 
which subnational governments raise their own funds through taxes, loans, fees, or sales of assets (Schneider 2003).

In order to understand the various aspects of decentralization, Ebel and Yilmar (2002) use four pillars for their assignment of intergovernmental fiscal systems: expenditure assignments, revenues assignments, inter-governmental transfers and subnational loans. Daniel Treisman finds five categories: structural, decision-making, resources, electoral and industrial decentralization (Treisman 2007). Bahl (2005) used four: expenditure, revenues assignment, inter-governmental transfers and subnational debt. Finally, Chin-hung (2007) used seven: political structure (subnational, federal and unitary systems and numbers of SNG); inter-governmental transfers are measured as the percentage revenue transfers over total SNG; tax autonomy, which is the percentage SNG as a tax; expenditure assignment; revenues assignment; borrowing power; political and hard budget constraints.

An example of an evaluation of revenue streams is in the replication of the Davoodi and Zou (1998) model, where the dependent variable is the annual per capita GDP growth rate and the proxy for decentralization is the total subnational share of government expenditure, net of grants. Davoodi and Zou (1998) analyzed empirically the impact of fiscal decentralization on economic growth and reported a negative relationship across 46 developing and developed countries. However, according to Martinez-Vazquez and $\mathrm{McNab}$ (1997) there are serious methodological issues in their analysis because of their measure of decentralization. Davoodi and Zou measure fiscal decentralization as a subnational share of total government expenditure reported in the GFS. Yet according to one report published by the World Bank: 
the subnational share of total government expenditure does not represent the multidimensionality of the fiscal decentralization process. Without controlling for autonomy over expenditure and revenue decisions and whether officials are democratically elected, the expenditure share of subnational governments as a fiscal decentralization variable means very little in representing the level of decentralization. If fiscal decentralization is defined as revenue autonomy of subnational governments, then estimation results might change (Ebel and Yilmaz 2002) p33.

Schneider (2003) agrees that subnational shares of government expenditure or revenue are not the best approximations of decentralization, but this does not mean that they are irrelevant. An additional component to measure fiscal decentralization is to measure the levels of local administrative autonomy. This is examined by evaluating the control exercised over local revenues. For example, one could look at the percentage of local revenues from total taxation to provide an indicator of the degree of subnational control over resources. Taxes are different from the total amount of resources, which is more a measure of wealth than administrative autonomy within the decision-making process.

Therefore, the measure of decentralization should consider the interaction between the relative size of subnational governments and their fiscal autonomy to administer programs. Such a measure will be computed in this dissertation as the "total own-source revenue ratio," which is the ratio of municipal governments' own-source revenue collection efforts over the expenditures such as towards public works and wage bill. This ratio quantitatively describes a city's tax effort and its decision to spend its budget on particular budget items. Therefore this study attempts to solve some of these problems by creating models using the dependent variable measured as GDP and several measures for fiscal autonomy and decentralization for important independent variables. Additionally, this study uses both a quantitative and qualitative analysis to test these assumptions. 
Overall this chapter has reviewed the current status of decentralization in Latin America. It has described the academic literature of decentralization, local economic development, and public finances within the region. Then an overview of how the concept of decentralization has been treated by Latin American scholars, in particular by dividing decentralization into political, administrative, and fiscal reforms, was reviewed. Furthermore, this chapter described the differences in measure for autonomy and defines how this study uses this concept in order to provide clarity in the results. The next chapter describes in detail the methods used in this dissertation. 


\section{CHAPTER III}

\section{RESEARCH METHODOLOGIES}

\subsection{Introduction}

The purpose of this chapter is to describe the research methods used in this dissertation, which addresses the degree of fiscal decentralization and autonomy levels that cities currently have in Latin America. Concurrent with the trends of decentralization is the rise of urbanization. For the first time in history, more of the world's population now lives in cities. With over 80 percent of the region's population living in urban areas, urbanization has affected Latin America more than other regions of the world. ${ }^{5}$ Public service demands will likely increase, and therefore state and local governments will be called upon to provide additional services, such as adequate infrastructure, waste management and transportation services for their residents. Arguably, to better manage this rapid growth, cities will need more capacities to encourage economic development, provide safe, livable communities, and improve the quality of life.

Local officials in many countries will, among other actions, need to improve their finances. This arguably could be a first step before accessing greater financing for urban infrastructure and other municipal services. Generally, municipalities have three different sources of funding through which they finance their operating and capital planning budgets: 1) own-source funding which comes from local taxation, fees and charges, 2) intergovernmental transfers which are funds transferred from the central to the local

\footnotetext{
${ }^{5}$ According to UN Habitat, "The total population of cities in the developing regions of the world already exceeds that of cities in all of the developed regions (by 1.3 billion people). By 2030, nearly 4 billion people, 80 per cent of the world's urban dwellers, will live in cities of the developing world." UN-Habitat. 2006. "Urbanization Facts and Figures." Pp. 4, vol. World Urban Forum III An international UN-Habitat Event on Urban Sustainablity. Vancouver, Canada: UN Habitat.
} 
level, and 3) money that cities borrow, such as through general revenue bonds, private sector loans or other forms of credit. It is argued that Latin American policymakers could improve cities by changing incentives structures for local public officials to collect more tax revenue. The current levels of federal transfers made to local government need to be better understood and reassessed. Arguably, if cities had more autonomy they would be able to spur more economic development.

The present chapter describes the research methods used in this dissertation. In general, a positivist approach is used to test whether fiscal decentralization helps economic development. This study uses a comparative analysis to test the levels of commitment to decentralization policies in Argentina and Mexico (George and Bennett 2005). This is done through an analysis of historical, legal and budget comparisons. Six case studies are used to understand municipal capacity, the levels of budget authority, and autonomy to make decisions. The following sections describe the research questions, the research instruments, definitions, data collection and statistical methods used.

\subsection{Research Questions}

The first research question asks whether state structure matters for municipalities to support economic development programs. In particular, does further fiscal decentralization increase the amount of economic development activities in a local area? To what extent does fiscal autonomy influence the economic development of a municipality? What factors generate greater or lesser fiscal autonomy for a municipality?

H1: The higher the degree of governmental decentralization (political, administrative, and fiscal), the more likely a municipality will have successful economic development activities. 
The second set of research questions seeks to understand the municipal capacity and the ways that cities are generating revenues to provide for economic development programs. Do cities with greater fiscal authority implement successful economic development programs? How are cities becoming more fiscally autonomous? What types of financial instruments are these cities developing to increase their local revenues?

$\mathrm{H} 2$ : If a municipality is more fiscally autonomous, the city will be more likely to have successful economic development activities.

H3: If a municipality has a higher degree of capacity (legal, fiscal, and professional development) to generate revenue, the city will realize more economic development activities.

\subsection{Research Design}

The methods employed in this dissertation are of two kinds, qualitative and quantitative. The research provides a qualitative comparative analysis of six cities in Argentina and Mexico. Academics argue that comparative research can benefit from historical sequences, especially when it takes into account the varied historical consequences of a particular event (Rueschemeyer and Stephens 1997). A study that uses this comparative approach can help with macro-sociological studies by eliminating problems such as the small n, lack of independent cases and provide a more solid explanation of their association for further causal exploration (King, Keohane, and Verba 1994). This dissertation compares Argentina and Mexico's histories in the hope of

providing a better understanding of what levels of fiscal federalism have developed in each country today and how public officials arrived at the decisions to promote decentralization. 
The cases were selected in two federalist countries in Latin America: Argentina and Mexico, which are in transition (George and Bennett 2005). An analysis of decentralization policies with regards to inter-governmental relations, historical political interactions between the national governments and the states is performed. Current fiscal policy regarding income generation and expenditures by the national, regional, and local governments is also discussed. A brief description of historical events is provided for context. The timeframe for this analysis is from 1980 to 2010, thus incorporating major political and economic transformations in both counties' recent histories.

\section{Qualitative Analysis}

To understand how the national decentralization policies impact the local governments, an analysis follows with two subnational governments and six cities selected as case studies. To eliminate variation among subnational governments, the selected cities are in the same subnational governments - the state of Guanajuato in Mexico and the province of Santa Fe in Argentina. The cities in each country include an industrialized city, a state capital and a small to mid-size town in order to analyze size, industrial strengthen and economic activity (see Table 3.1).

\begin{tabular}{|l|l|l|l|}
\hline Table 3.1: Case Selection: Industry-type and Size of Cities \\
\hline State, Country & Large Industrial Cities & State Capitals & Mid-size towns \\
\hline Santa Fe, Argentina & Rosario & Santa Fe & Rafaela \\
\hline Guanajuato, Mexico & Leon & Guanajuato & San Miguel de Allende \\
\hline
\end{tabular}

The State of Guanajuato and the Province of Santa Fe provide examples for how subnational governments operate in Mexico and Argentina. Both have distinctive colonial histories, economic development and have played roles as major centers for political leaders in the recent democratization periods. These governments are only a selection of 
the larger federations; however they can provide a comparative viewpoint for how subnational governments work within Latin America.

At the subnational level, the socialist party governs the province of Santa Fe and a right leaning pro-business party governs the state of Guanajuato. Even with these opposing political ideologies, the cities own-source revenues and investment decisions should be more dependent on the size of the city, its natural economic endowment and national transfers than its political affiliation. The subsequent chapters are arranged in the following sections: background to the internal politics, description of natural endowment, an analysis of the cities' finances, and finally, the economic development efforts of each subnational government, paying particular attention to each city's recent economic history.

Since the cases are situated in federal governments, each state or province has independent constitutions. The fiscal authority for each city, such as its ability to raise taxes and fees, issue public debt, re-evaluate property and change the tax rate, is managed by each subnational constitution. The examination of each cities legal framework is also considered in the analysis of each state government.

Case Analysis

This study compares different amounts of fiscal autonomy and contrasts them with each city's investments in economic development programs. Each of the six city governments has engaged in a range of measures to increase revenue for their local budgets. Fiscal autonomy is evaluated as regards to both budget composition and local authority. First, each community's fiscal capacity is assessed. It is measured as the authority (high, medium and low) of a city to be able to increase taxes, set tax rates, issue 
bonds, have the discretion in the use of trust funds, and have the ability to reserve funds. An assignment is provided to evaluate whether the cities have fiscal capacity to manage and pay for economic development projects, which is described in the set of questions in table 3.2.

\begin{tabular}{|l|c|}
\hline Table 3.2 Revenue Generation Authority* & $1-3$ \\
\hline Does the municipality have a high or low ability to increase taxes? & \\
\hline Does the municipality have a high or low ability to set tax rates? & \\
\hline Does the municipality have a high or low capacity to issue bonds? & \\
\hline $\begin{array}{l}\text { Does the municipality have high or low capacity for discretion in the use of trust } \\
\text { funds? }\end{array}$ & \\
\hline Does the municipality have a high or low ability to roll over funds? & *Composite measure for autonomy. (This will be evaluated in a likart scale of 1-3, \\
measured as high, medium to low and then summed for a count variable).
\end{tabular}

Second, different types of interventions are compared in regards to producing fiscal autonomy and contrast them in terms of various economic development indicators. After conducting preliminary interviews in Argentina and Mexico during the summer of 2009 , it became apparent that each city has emphasized a specific funding source to strengthen their local budgets. Specifically, for the case selection, the cities were first divided by the degree of autonomy, and from where the municipality is collecting its local revenue streams. They are categorized as autonomous (higher percentage of ownsource resource collection), dependent (high degree of inter-governmental transfer from the national and local government) or mixed (equally dependent on intergovernmental transfers to the collection of own-source revenue), which is demonstrated in table 3.3. 


\begin{tabular}{|l|l|l|}
\hline Table 3.3: City's Efforts at Revenue Collection \\
\hline $\begin{array}{l}\text { Degree of } \\
\text { Autonomy }\end{array}$ & City & City Financial Revenue Efforts \\
\hline Autonomous & Rosario & The city created trust funds to finance public programs. \\
\hline Dependent & Rafaela & $\begin{array}{l}\text { The city has strong party ties to the national government to } \\
\text { finance public programs. }\end{array}$ \\
\hline Mixed & Santa Fe & $\begin{array}{l}\text { The city redesigned its cadastre to enhance property taxes to } \\
\text { finance public programs. }\end{array}$ \\
\hline Autonomous & Leon & $\begin{array}{l}\text { The city relies upon the use of municipal bonds to finance } \\
\text { public programs. }\end{array}$ \\
\hline Dependent & $\begin{array}{l}\text { San Miguel } \\
\text { de Allende }\end{array}$ & $\begin{array}{l}\text { The city relies upon its expatriate community for generating } \\
\text { revenue for public programs. }\end{array}$ \\
\hline Mixed & Guanajuato & $\begin{array}{l}\text { The city has incorporated public facilities and charges user- } \\
\text { fees to finance public programs. }\end{array}$ \\
\hline
\end{tabular}

Next, the autonomy of the budget revenues is quantified using a measure of Total Own-Source Revenue (TOSR). This involves the inputs of local taxes (property, fees, and fines), and public loans/debt minus inter-governmental transfers and international or philanthropic aid. Total own-source revenue is demonstrated in subsequent graphs, making comparisons with public expenditures such as wage bill (public employment), public works and other expenditures (which are a total of all other expenses made by the city government). These variables are calculated as percentage of TOSR.

The research then compares the six cities and their efforts to promote economic development programs. The dependent variable is the economic development programs. Specific programming that a city has developed including for example, job fairs, training centers, promotion activities for locally produced products will be examined. Further examples of specific economic development programs evaluated are found in Table 3.4. 


\section{Table 3.4 Local Economic Development Programs}

1. The municipality has a local economic development promotional office.

2. The municipality organizes annual fairs and carnivals to advertise local products.

3. There are prizes and annual acknowledgement of best business and entrepreneurs.

4. The municipality has up-to-date maps and locations of local businesses.

5. The local government is open to free access of information to open businesses: access, roads, and productive infrastructure, among other things?

6 . The local government has one-window to set up business activities, commercial and industrial licensing?

7. The municipality has formal connections to the local business community.

8. The municipality has developed support programs for new small business leaders?

9. The municipality has an updated plan of registered commercial plants and productivity activities in your area?

10. The municipality receives international cooperation?

11. The municipality has partnerships with local organizations: sister city programs, with local universities, international cooperation agencies.

12. The municipality is a member of an inter-municipal association for economic development.

13. The municipality administers a micro-credit plan for small and medium size businesses.

The key independent variables include: political ideology, intergovernmental structure, city's geography, mayoral leadership, and the professional development of the municipality's staff. Based on a review of the literature it is assumed that:

- If the local political leadership is involved in the national politics of the country then it will be able to bring more finances back to the local community and establish more successful economic development programs.

- If the political leadership is more conservative and business oriented, for example by providing favors in terms of land or taxes to companies, then the city will have more successful economic development programs.

- If the city is located in a resource rich area and/or has close access to roads and/or is a transportation hub for the country, then the city will be more likely to develop economic development programs. 
- If the municipality has had a highly energetic mayor and the municipality's staff has a high level of professional development (i.e. with several holding advanced degrees), then the city will be more likely to establish economic development programs.

Each city is evaluated in terms of possessing these independent variables. This research compares local capacity and explores the role that fiscal autonomy plays in encouraging local economic development programs. It focuses on municipal capacity to innovate and create financial mechanisms those cities are using to finance the economic development programs. The same six cities are evaluated again for this portion of the research.

\section{Quantitative Analysis}

After studying the results from the qualitative case studies, a large quantitative dataset from Mexico is analyzed. The research provides a statistical analysis to evaluate the relationship of city autonomy to the economic development programs (measured as job creation). A formal linear regression is used to test a model with data collected from four sources: Mexico's National Institute for Statistics and Geography (INEGI), the National Congress' public finance database (CEFP), census data (CONAPO) and finally, the federal agency which researches municipal development (INAFED). (Martínez Pellégrini, Flamand, and Hernández 2008) developed in conjunction with INAFED a large database, which reports on municipal social, economic, environmental services and institutional development, called the IDMB (Indice de Desarrollo Municipal Basico). The IDMB is also used to test these results.

Finally, a large-scale quantitative analysis is done with data from mayors and local authorities throughout the region in an effort to generalize the case study results. A 
survey was created and distributed at a large conference of local authorities and to several Latin American municipal associations in an effort to evaluate the performance of mayors and other local authorities (Appendix 1). The survey seeks to explore both how economic development programs work and the perception of autonomy that local authorities experience. Periodic requests were also sent using electronic communication.

A model was built on the survey data that includes responses from mayors, city council members and executives from 13 countries in Latin America, which attempted to gauge whether the local officials implement economic development programs. The dependent variable is the number of jobs created in a local area as a proxy for measuring economic development programs. The independent variables include measures of fiscal, administrative, and political autonomy. Finally, the study attempts to control for municipal environmental factors. The survey evaluates the impressions of mayors and local authorities on establishing economic development programs and the autonomy they experience. Table 3.5 provides indicators used in the quantitative analysis. They include mayor's perceptions of fiscal, administrative, and political decentralization. The amount of economic growth measured as the number of jobs created, types of business friendly programs and controls for other natural endowments. 


\begin{tabular}{|l|l|}
\hline Table 3.5 Quantitative Analysis Indicators \\
\hline Indicators & Description \\
\hline Economic Development & $\begin{array}{l}\text { Measured by the \# Jobs, small businesses, GDP in a } \\
\text { particular municipality, Economic Development programs } \\
\text { created within the Municipality }\end{array}$ \\
\hline Economic Growth & $\begin{array}{l}\text { Composite of questions, which determine what pro-business } \\
\text { policies the municipality has implemented in the past year. }\end{array}$ \\
\hline $\begin{array}{l}\text { Business Friendliness } \\
\text { Policies }\end{array}$ & Defined budget, creating and calculating taxes and expenses \\
\hline Decentralization & $\begin{array}{l}\text { Measures of the budget autonomy by inputs of local taxes } \\
\text { (Property, fees and fines), and public loans/debt minus inter- } \\
\text { governmental transfers and international or philanthropic aid }\end{array}$ \\
\hline Budget Autonomy & of Budget Autonomy \\
(aka Autonomy) & Level of decision making authority, originating internally \\
\hline Political Autonomy & $\begin{array}{l}\text { Level of capacity to define municipal authorities, processes, } \\
\text { and purchases }\end{array}$ \\
\hline $\begin{array}{l}\text { Administrative } \\
\text { Autonomy }\end{array}$ & $\begin{array}{l}\text { Control Variables: Total Budget Interval Estimated in U.S. dollars, Population } \\
\text { measured in thousands, Administrative Territory, \% of poverty in municipality }\end{array}$ \\
\hline
\end{tabular}

\subsection{Definitions}

This dissertation uses the following key terms, which are defined in this section. Fiscal decentralization is defined as the assignment of expenditures functions and revenues sources to subnational levels of government. Subnational levels of government (SNG) include state or provincial governments and local governments-cities, metropolitan regions or municipalities - that report to the national government. SNG may also be sub-divided into counties or other administrative units.

Within many econometric studies, fiscal decentralization is measured as subnational government revenue and expenditure as a percentage of total government revenue (TOSR). Typically studies warn that too much fiscal decentralization could promote macroeconomic instability may be harmed by too much SNG spending, as such many studies have suggested soft budget constraints for SNG borrowing. Advocates promote the arguments of economic efficiency. They include an analysis of economic 
performance, fiscal performance or governance performance. But a more specific definition should be used for this study.

For example, the OECD quantitative analysis studies use subnational government expenditures as its dependent variable and adjusts independent variables for tax rates and the base, public debt and other types of revenue sharing (de Mello 2009; Gemmell, Kneller, and Sanz 2009; Joumard, Kongsrud, Nam, and Price 2004). Revenues are decided by the national legislature and crafted annually by central government as a part of the budget. If the central government sets the tax rate and base for subnational governments then there is little autonomy for the local government to regulate tax collection. The World Bank uses measures such as expenditure assignments, revenues regulatory frameworks for subnational borrowing and the characteristics of the transfers in its qualitative analysis. In order to understand the authority of local governments to make decisions in their budget decisions, the legal framework of each city is evaluated.

Additionally, economic performance also can be measured in different ways, for example growth rates, inflation rates, and levels of income or the purchasing power at the local level. This dissertation uses Gross Domestic Product (GDP) as the level of economic performance at the subnational level (where data are available). Finally, fiscal performances are the level of budget deficit and are measured in government debt over GDP. Where data are available, GDP at the municipal level is used in this dissertation. This chapter described the research questions, methods, and definitions used in this dissertation.

Therefore the next chapter will provide a historical analysis of how the decentralization process has taken place within the region. Argentina, which has 
traditionally been a decentralized federation, has recently increased tax revenues and promoted more centralized fiscal policies in order to promote macroeconomic stability. Mexico, which has traditionally been a centralized federation, has begun to decentralize expenditures to subnational government, although similar levels revenue capacity or authority as in Argentina has not joined this process. The next chapter will look at how these transitions have taken place. 


\section{CHAPTER IV}

\section{THE HISTORY OF ARGENTINA AND MEXICO'S \\ DECENTRALIZATION PROCESS}

\subsection{Introduction}

The purpose of this chapter is to understand the history and context of how Argentina and Mexico first crafted their federations. By using a comparative historical approach, this chapter evaluates the levels of decentralization and centralization of the Argentine and Mexican federations' overtime. The chapter describes the recent changes in the intergovernmental systems, paying specific attention to the fiscal reforms.

Argentina had a loose federation during a majority of the 19th and 20th century; only beginning in the 1970 s the country began to decentralize some areas of public policy such as education and health. By collecting more national taxes and managing its failing economy (macro-economic stabilization policies), especially after the 2001 economic crash, Argentina is becoming more centralized.

During most of the 19th century, Mexico tried to create a unified federation but was dominated by political strife. It was solidified only when the PRI gained power in the early 20 th century. Decentralization reforms began in the late 1970 s with administrative and political reforms, when opposition parties were allowed to run and lead the country, which opened the country up to democracy. Fiscal reforms were dominated by expenditure decentralization, which redistributes federally funded grants based on a formula. The national budget process is managed directly by the federal executive.

Academics are now questioning the effectiveness of formula-driven redistributions (Falleti 2010; Weingast 2006). Currently the test is whether fiscal 
federalism is based on market-based incentives or on political constraints. Arguably, this research will help better inform policy on how to create the optimal amount of tax ratios at the national and subnational level.

This chapter provides a brief description of the historical developments for each country. It is divided into two sections, first explaining Argentina and then Mexico. Each section includes a brief description of how the two federations were established. Then the chapter describes the modern day reforms each country took after becoming democracies, paying particular attention to Argentina Fiscal Pacts post 1990s and Mexico's municipal reforms beginning in 1997 . The chapter describes how each country's history has crafted its current institutional arrangement and describes their tensions within their intergovernmental relations.

\subsection{Argentina}

The Argentina federation was first established in 1853. Over the following 140 years, the federation was marked by several periods of oligarchy and military rule, which finally transformed into a democracy in 1983. Shortly after this last transition, when the military authority handed over its power to civilian authorities, Argentina instituted the 1994 constitution, which is in operation today.

For a majority of the 19th and 20th century, strong provincial leaders managed Argentina by sending political representation to Buenos Aries to oversee domestic affairs. For much of this time, the federal government retained control over matters such as the regulation of commerce, customs collections, currency, civil or commercial codes, and the appointment of foreign diplomats. But the relationship between the federation and the provinces has fluctuated, especially with the number of policies that seek to improve the 
macroeconomic stability of the country and the promotion of economic growth within the subnational governments.

National political representation alternated between the Partido Justicalists, (PJ) a Populist Party, and the Union Civil Radical (UCR), a conservative Christian Democratic Party. The political struggle was also between Buenos Aires and the interior provinces, with long periods of tension regarding the division of powers between the central government and provincial bodies. According to Benton (2001), "provincial party branches had their own constitutions, rules and procedures', elected party officers, party activities and membership's lists. Often local party groups had their own names, as well as reserved the right to forge alliances and other parties at election times" (Benton 2001).

The Argentine Federal Co-participation System (FCS) was established in the 1930s and is characterized by a revenue sharing system, which includes mandatory payments from provinces into the national treasury to the co-participation fund. There are two basic ways that these funds are paid back from the national treasury to the provinces. These include: 1) transfers, such as the block grants in the United States, to provinces that have general responsibility for how the funds are spent and 2) National Treasury Grants (ATNs Aportes del Tesoro Nacional) which are non-conditional transfers for provinces on non-specific projects. ${ }^{6}$ The co-participation or revenue sharing funds are different than ATNs or other conditional transfers. The revenue-sharing grants are similar to unconditional block grants in that they are pre-determined by a formula and automatically distributed from the national government to the provinces. The ATNs were created in the 1853 Constitution as way for the federation to subsidize poorer provinces (Habibi,

\footnotetext{
${ }^{6}$ In general, scholars sometimes interchange the revenue sharing (monies sent to the national treasury) with the transfers (monies sent back to the provinces) by mistake.
} 
Huang, Miranda, Murillo, Ranis, Sarkar, and Stewart 2001). Furthermore, there are a few additional smaller funds for special projects such as FONAVI (housing) Royalties (for oil and natural gas producing provinces) or FDR (for regional development grants). These last funds are relatively small compared to the transfers, which are these mandatory block grants sent from the treasury to the provinces. One public official reported that these funds were transferred from the national treasury to the provinces daily and the amounts were based on the commodity prices. Table 4.1 shows several of the special accounts that the Argentine government has created to decentralize public programs.

\begin{tabular}{l} 
Table 4.1 Principal Federal Transfers to Argentine Provincial \\
Governments, 1973- 1995 (Percent of Total Transfers) \\
\begin{tabular}{|l|l|l|l|l|l|l|r|}
\hline Year & ATN & FONAVI & $\begin{array}{l}\text { Corp. } \\
\text { Vial }\end{array}$ & FEDEI & FDR & Royalties & TOTAL \\
\hline $1973-80$ & 52.4 & 8.1 & 4.6 & 0.4 & 2.9 & $\mathbf{3 . 3}$ & $\mathbf{9 6 . 5}$ \\
\hline $1988-90$ & 61.4 & 10 & 3.2 & 0.3 & 1 & $\mathbf{9 . 2}$ & $\mathbf{8 6 . 2}$ \\
\hline $1991-95$ & 71.6 & 6.2 & 1.6 & 0.5 & 0.5 & $\mathbf{4 . 1}$ & $\mathbf{8 7}$ \\
\hline All years & $\mathbf{5 6 . 7}$ & $\mathbf{8 . 8}$ & $\mathbf{3 . 8}$ & $\mathbf{0 . 5}$ & $\mathbf{1 . 8}$ & $\mathbf{5 . 6}$ & $\mathbf{9 2 . 9}$ \\
\hline
\end{tabular} Source: (Benton 2001) pg 491. \\
\hline
\end{tabular}

\section{History of Centralization}

Beginning in 1935, revenue sharing between levels of government marked the first change in the fiscal relationship for the Argentine Federation. Yet, it was not until Juan Domingo Peron became president (1946-1955 and again 1973-1974) representing the PJ, which consolidated the nation. ${ }^{8} \mathrm{He}$ is also known for uniting the urban workers and enlarging the national bureaucracy. He did this by increasing federal taxes on agricultural exports to implement an import substitution model of economics that also

\footnotetext{
${ }^{7}$ Note: ATN: Aportes del Tesoro Nacional or National Treasury Grants; Cop. Vial: Coparticipación Vial or Highway Fund; FDR: Fondo de Desarrollo Regional or Regional Development Fund; FEDEI: Fondo de Desarrollo Eléctrico del Interior or Energy Development Fund; FONAVI: Fondo Nacional de Vivienda or National Housing Fund; Royalties: Payments to oil and natural gas producing provinces.

8 The PJ is later to also be known for his leadership as the Peronist party, after Juan Domingo Peron.
} 
increased manufacturing jobs in Buenos Aires (Benton 2001). His political leadership was supported by urban labor groups, which promoted more centralized government and agricultural landowners promoted a more decentralized federation.

The change in the intergovernmental system and the percentages of allocations to municipal governments increased tension between the federal government (typically managed by the president, or the military, depending upon the year) and the provincial governments. Because some of the funding to SNG is discretional, academics have found a correlation between the changes in the intergovernmental system with party leadership (Benton 2009). This is particularly true when the Peronist Party (PJ) governed the federal government; there are generally increases in federal transfers and therefore more centralization of power over the federation (Diaz-Cayeros 2006; Eaton 2001; Eaton and Dickovick 2004).

Table 4.2 outlines the changes to the co-participation system from 1935 to 1999 (Eaton 2001). It illustrates how presidents increased taxes (excise, sales and VAT) and set the distribution of those funds between the federal government, the provincial governments and created a federal district to manage specific funds (located within Buenos Aires).

\begin{tabular}{|c|c|c|c|c|}
\hline $\begin{array}{l}\text { Administration } \\
\text { (Years in power) }\end{array}$ & $\begin{array}{l}\text { How came } \\
\text { to power }\end{array}$ & $\begin{array}{l}\text { Date } \\
\text { (Law No.) }\end{array}$ & Nature of Change & $\%$ Change \\
\hline $\begin{array}{l}\text { Justo } \\
\text { (Jan 32-Jan38) }\end{array}$ & $\begin{array}{l}\text { Election } \\
\text { with fraud }\end{array}$ & $\begin{array}{l}1934 \\
(12,139) \\
1934 \\
(12,143) \\
1934 \\
(12,147) \\
\end{array}$ & $\begin{array}{l}\text { Revenue sharing of excise taxes } \\
\text { Revenue sharing of income and of sales taxes } \\
(82.5 / 17.5 \% \text { split })\end{array}$ & $\mathrm{n} / \mathrm{a}$ \\
\hline \multicolumn{5}{|c|}{ Ortiz/Castillo (Jan 38-June 43) Election with fraud No change } \\
\hline $\begin{array}{l}\text { Ramirez/Farrell } \\
\text { (June 43-June 46) }\end{array}$ & $\begin{array}{l}\text { Military } \\
\text { coup }\end{array}$ & 1943 & Creation of new tax on profits, not shared & $\mathrm{n} / \mathrm{a}$ \\
\hline $\begin{array}{l}\text { Peron } \\
\text { (June 46-sept 55) }\end{array}$ & $\begin{array}{l}\text { Democratic } \\
\text { Elections }\end{array}$ & $\begin{array}{l}1947 \\
(12,956) \\
1951\end{array}$ & $\begin{array}{l}\text { Increase provincial shares and includes } \\
\text { profits tax in pool }(79 / 21 \% \text { split) } \\
\text { Creation of new tax on inheritances, shared }\end{array}$ & $\mathrm{n} / \mathrm{a}$ \\
\hline
\end{tabular}




\begin{tabular}{|c|c|c|c|c|}
\hline & & $\begin{array}{l}(14,060) \\
1954 \\
(14,390\end{array}$ & $\begin{array}{l}\text { with SNG } \\
\text { Regulatory degree decrease SNG share } \\
\text { Increase provincial share of excise tax }\end{array}$ & $\begin{array}{l}32 \% \\
\text { increase }\end{array}$ \\
\hline \multicolumn{5}{|c|}{ Leonardi/Aramburu (Sep 55-May 58) Military coup No change } \\
\hline $\begin{array}{l}\text { Frondizi } \\
\text { (May 58-Mar 62) }\end{array}$ & Elections & $\begin{array}{l}1959 \\
(14,788)\end{array}$ & $\begin{array}{l}\text { Adopts five year transition period which } \\
\text { SNG shares will be doubled } \\
\text { ( } 58 \% \text { fed } / 36 \% \text { prov } / 6 \% \text { fed cap split) }\end{array}$ & $\begin{array}{l}100 \% \\
\text { increase }\end{array}$ \\
\hline \multicolumn{5}{|c|}{ Guido (Mar 62-July 63) Military Coup No change } \\
\hline $\begin{array}{l}\text { Illia } \\
\text { (July 63-June 66) }\end{array}$ & Elections & $\begin{array}{l}1964 \\
(16,463)\end{array}$ & $\begin{array}{l}\text { Provincial shares in existing pool increase } \\
\text { (54\% fed } / 36 \% \text { prov } / 6 \% \text { fed cap) }\end{array}$ & $\begin{array}{l}11 \% \\
\text { increase }\end{array}$ \\
\hline $\begin{array}{l}\text { Ongania/ } \\
\text { Livingston } \\
\text { (June 66-Feb 71) }\end{array}$ & $\begin{array}{l}\text { Military } \\
\text { Coup }\end{array}$ & $\begin{array}{l}1967 \\
1968\end{array}$ & $\begin{array}{l}\text { Provincial shares and federal capital share } \\
\text { reduce }(49 \% \text { fed } / 41 \% \text { prov }+ \text { Fed cap) }\end{array}$ & $\begin{array}{l}11 \% \\
\text { decrease } \\
\text { for SNG }\end{array}$ \\
\hline $\begin{array}{l}\text { Lanusse } \\
\text { (Feb 71-May73 }\end{array}$ & $\begin{array}{l}\text { Internal } \\
\text { Military } \\
\text { Coup }\end{array}$ & $\begin{array}{l}1973 \\
(20,221)\end{array}$ & $\begin{array}{l}\text { Increase provides and broadens set of taxes } \\
\text { in pool }(48.5 \% \text { fed } / 48.5 \% \text { prov } / 1.8 \% \text { fed } \\
\text { cap) }\end{array}$ & $\begin{array}{l}21 \% \\
\text { increase }\end{array}$ \\
\hline $\begin{array}{l}\text { Campora/Lastiri/ } \\
\text { Peron } \\
\text { (May 73-Mar 76) }\end{array}$ & Elections & $\begin{array}{l}1973 \\
(20,633) \\
1975 \\
(21,251) \\
\end{array}$ & $\begin{array}{l}\text { VAT introduced and included in pool } \\
\text { Vat Taken out of revenue pool but provinces } \\
\text { allowed to keep collecting }\end{array}$ & $\mathrm{n} / \mathrm{a}$ \\
\hline $\begin{array}{l}\text { Videla/ Viola/ } \\
\text { Galtieri/ Bignone } \\
\text { (Mar 76-Dec 83) }\end{array}$ & $\begin{array}{l}\text { Military } \\
\text { Coup }\end{array}$ & $\begin{array}{l}1980 \\
(22,293) \\
1981 \\
(22,451)\end{array}$ & $\begin{array}{l}\text { Amount deducted from revenue sharing pool } \\
\text { equal to cost of financing social security, } \\
\text { SNG reduced to } 29 \% \\
\text { Fed Capital eliminated from revenue sharing }\end{array}$ & $\begin{array}{l}44 \% \\
\text { decrease } \\
100 \% \\
\text { decrease }\end{array}$ \\
\hline $\begin{array}{l}\text { Alfonsin } \\
\text { (Dec83-July 89) }\end{array}$ & Elections & $\begin{array}{l}1988 \\
(22,548)\end{array}$ & $\begin{array}{l}\text { Provincial Share increase to } 56.7 \% \text { and fed } \\
\text { decreased } 42.3 \% \text {; tax on gas included }\end{array}$ & $\begin{array}{l}95 \% \\
\text { increase }\end{array}$ \\
\hline $\begin{array}{l}\text { Menem } \\
\text { (July89-Dec 99) }\end{array}$ & Elections & $1992 / 93$ & $\begin{array}{l}\text { Fiscal pacts that deduct revenues from the } \\
\text { tax pool in exchange for guarantee revenues; } \\
\text { some taxes removed from pool }\end{array}$ & $\begin{array}{l}\text { Estimate } \\
\text { Vary }\end{array}$ \\
\hline
\end{tabular}

Argentina's intergovernmental tension has been more acute in the past 30 years (1980-2010). When the president's constitutional powers were invoked, it further influenced the continuing realignment of Argentina's intergovernmental system. ${ }^{9}$ For example, during the most recent military junta governments, before Juan Peron resumed power in 1973 and again after the 1976 coup, all local legislatures could be dissolved and

\footnotetext{
9 The first of these powers was designed to "guarantee the republican form of government in the provinces." Since the adoption of the 1853 constitution, the federal government has intervened over 200 times, mostly by presidential decree. Typically under military dictatorships (between 1966 and 1973 and again from 1976 and 1983) is when they had the authority to declare vacant, nullify appointments, and supervise local elections at the provincial and municipal levels.
} 
the military's appointed provincial governors. ${ }^{10}$ With the restoration of democracy in 1983, local elections returned. ${ }^{11}$ Since that time, the provincial governors and subnational leaders are once again elected for four-year terms.

Benton (2001) shows that in 1973 after the re-election of Peron, the share of revenues, or the payments of provincial governments to the national government, rose from 45 percent in 1971 to over 70 percent in 1977, illustrated in figure 4.1. The provincial governors demanded the national government to be compensated for the revenue sharing increases, which increased to as high as 75.8 percent.

Figure 4.1 Argentine Revenue Sharing 1973-1995 (percent of total transfers)

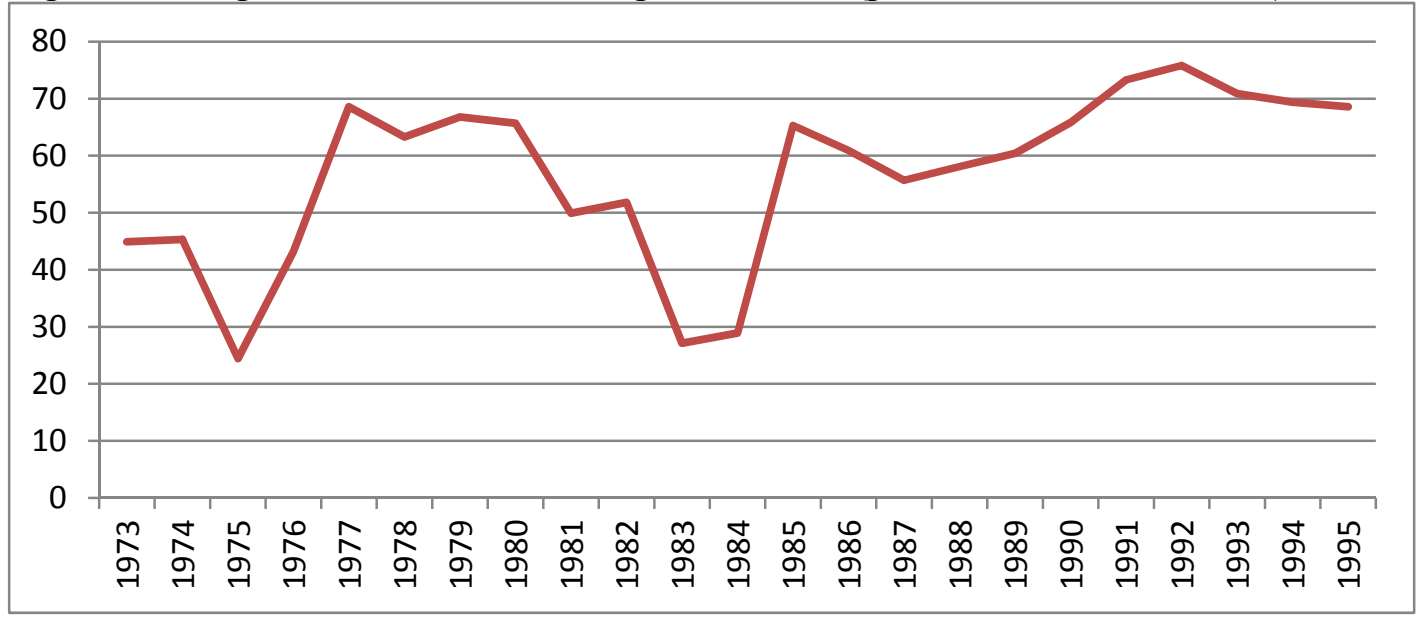

Source: (Benton 2001) pg 491

The academic literature (Benton 2009; Eaton and Dickovick 2004; Falleti 2010) states that it was not until after Peron's death in 1974 that the Argentine Federation began to reassess the distribution and decentralization of national functions with the provinces.

\footnotetext{
10 Military rulers led Argentina from 1966-1973, when the PJ resumed power and Juan Domingo Peron (PJ) returned from Exile in Spain in 1973, but was seceded by his wife María Estela Martínez de Perón (PJ), 1974-1976, after being shot in office in 1974. The military returned to power from 1976-1983 when under free and fair elections, Raúl Alfonsín (UCR) was elected president (1983-1989). This was the last time the military ruled in Argentina. In 1994, Carlos Menem (PJ) changed the Constitution to be reelected in 1995.

11 In 1973 with Peron return to power, provincial and municipal governments followed the return to constitutional government, but after the March 1976 coup, the federal government again intervened to remove all provincial governors and impose direct military rule over all municipalities.
} 
For example, decentralization of health and primary education began during the military dictatorship in the 1970's; President Alfonsin created the New Partnership Scheme in the 1980's, and finally, President Menem further devolved health and education policies in the 1990's. Many of these programs, known as unfunded mandates, were designed to decentralize administrative functions without necessarily promised financing.

This created a secondary objective of changing the "effective partnership" between the state and national governments. There has always been a lack of coordination of spending and borrowing in Argentina, often creating successive taxes and overlapping laws. For example the Law 22,201 of 1973 (primary and secondary distribution) and the Law 23,548 of 1987 (political crisis) have created serious over spending problems for the country (Cetrángolo and Gómez-Sabaini 2007).

\section{Return to Democracy}

The most recent phase of "centralization" began when the Radical Civic Union (in Spanish, Unión Cívica Radical, UCR), which controlled the federal government from 1984 to 1987 , but lost its control in Congress. The president at the time "enjoyed enormous discretion over the size and timing of revenue transfers to the provinces, where a majority of which were governed by the opposition Peronist Party" (Eaton and Dickovick 2004). When Raúl Alfonsín (1983-1989) came to power representing the UCR, he modified the 1973 co-participation law that was to expire in 1987. Two proposals were drafted and heatedly debated in Congress, although neither was approved. While unresolved, the UCR transferred revenue through bilateral agreements with a large proportion of discretionary funds (ATNs). 
Even though many UCR provinces saw increases in their state budgets because the federal government had more discretionary funds to spend on these states, the party lost seats in the 1987 midterm Congressional election. By the end of the year, the PJ and UCR governors inevitably agreed to renegotiate a new co-participation plan (Falleti 2010). The results left several unfunded mandates without adequate redistribution of revenue sharing. In the same year, the provincial shares increased to 56.7 percent and the federal shares decreased to 42.3 percent. Taxes on gasoline also were included in the pool. Yet, the fiscal pacts that recentralized shared-revenues did not last long, especially when hyperinflation began to affect the Argentine economy in 1989. The financial crisis created a political crisis. President Alfonsín was forced to leave the presidency early, allowing Carlos Menem (1989-1999) to take his place.

According to Eaton and Dickovick (2004), when the Peronist party was victorious in the 1987 legislative election, they encouraged a recentralization of the fiscal policies and passed the co-participation law. This allowed the first automatic revenues to be transferred to the provinces. This further influenced President Menem to pass the Convertibility Law, which allowed the peso to equal one US dollar. At this time, several fiscal pacts were made between the president and the governors, which transferred key responsibilities to the provinces without increasing revenues. The Fiscal Pacts of the early $1990 \mathrm{~s}$ can be considered to be unfunded mandates, since they decreased responsibility (administrative decentralization) without sufficient resources.

The National Education Congress of 1988 unanimously voted in favor of the policy which lead to President Menem's proposal to decentralize secondary education in 1990 (Falleti 2010). According to Falleti, Congress approved the legislation in 1992 because it 
was attached to a tax bill written by the Minister of the Economy Domingo Cavallo, a bill that also was set to lower inflation and create economic stability. Cavallo believed that the provinces could afford to manage the schools with their own revenues instead of effectively requesting an increase in revenue sharing. According to Falleti (2010), this was the prevailing opinion of the PJ ruling coalition lead by José Octavio Bordón, a PJ governor of Mendoza. Cavallo convinced PJ governors to buy into the plan, declaring that since the enactment of the National Convertibility Law, total public income was growing faster than sub-national expenditures from 1987-1991 (Falleti 2010). The state's governors reluctantly agreed to the transfers with a financial guarantee (Article 15 of Law 24,049).

The Fiscal Pact in 1991 was an agreement that deducted 15 percent from the revenue pool in exchange for guaranteeing that the transfers would not dip below a minimum monthly floor of $\$ 725$ million pesos. According to Eaton and Dickovick (2004) the second pact was an exchange for discretionary provincial tax and social security reforms. Under this pact, the federal government raised the average monthly guarantee to $\$ 740$ million pesos and increased federal control over the design of sub-national economic policies. As inflation hit again in the late 1990s, it was estimated that the provinces lost $\$ 9.3$ billion dollars from having signed the transfer law (Falleti 2010). Likewise, the inflation continued to increase and the convertibility of the Argentine peso collapsed, thereby provincial governments increasingly needed to take out private loans to pay for public sector activities.

Planning his re-election, Menem called a constitutional assembly in 1994. With the backdrop a majority in Congress and an undivided government, Menem attempted to 
change the election laws (Falleti 2010). One of the bargaining chips the UCR had was to create an independent federal district and call for the direct election of the Mayor of the City of Buenos Aires, a long-time political bastion for the UCR (Falleti 2010). Prior to this, the President appointed the Mayor of Buenos Aires, and by law, the President and Congress controlled any legislation that affected the city (Rosenbaum and Rodriguez Acosta 2008). Constitutional reforms led to an elected mayoral position, and a 60member legislature. Congressional members are elected by proportional representation to four-year terms with the possibility to be re-elected.

Beginning in 1995, Menem faced a divided Congress during his second term in office. The balance of power shifted away from the governors to the federal government. Regardless of his 1995 re-election, Menem faced the negative effects of Mexico's tequila crisis in 1994 on the Argentine economy. He had to recentralize power to manage the economy and did so by successfully privatizing provincial banks. Further reforms were made such as simplifying the tax code, enacting fiscal reform, strengthening the tax agency, liberalizing internal and external markets, and privatizing other state-owned enterprises (Tommasi 2002). The changes were successful and the economy saw a positive growth rates and sharp decrease in poverty rates, which impressed not only private investors but also academics and international policymakers alike. The reforms made Argentina seen as an economic model to be followed internationally (Tommasi 2002).

Yet, Argentina's leading role in international economic policy was short lived after the country was obliged to default on its international debt obligations. Many academics suggest that the country's default originated from the explosion of subnational debt 
(Abuelafia, Berensztein, Broun, and Di Gresia 2004; Bonvecchi 2010; Cetrángolo O. and Jiménez 2003; Dillinger and Webb 1999; Eaton 2001; Falleti 2010; Melamud 2010; Melo 2007; Tommasi 2002; Tommasi, Saiegh, and Sanguinetti 2001). Much of this debt was issued in pesos prior to the Convertibility Law, which pegged one dollar to each peso. Mandatory co-participation transfers were established in the fiscal pacts at a fixed rate in dollars. As a result, the provincial debt was tied to the availability of dollars and when inflation hit, it caused public expenditures to increase while the transfers remained the same. Many provincial governors took out public loans to bridge the fiscal gap in their budgets. This in turn caused the national government to suffer instability leading it to default. Several provinces requested bailouts when they too generously paid out benefits, the fiscal deficit tripled from 1996 to 1998 (Tommasi, Saiegh, and Sanguinetti 2001).

Faced with a deteriorating budget balance and growing debt payments, the Argentine Congress approved a Fiscal Solvency Law in September 1999 (Braun and Tommasi 2002). The law sought to promote countercyclical fiscal funds and stipulated multiyear budgeting. The Fiscal Solvency Law set a nominal ceiling for the non-financial public sector deficit. This ensured the repayment of public loans by SNG, suggesting that those funds could not be used to pay salaries of public employees (wage bill). The subnational accounts became insurmountable, and the national government started to borrow more from international creditors, typically with interest rates established in U.S. dollars. The subnational debt distorted the Argentine economy (Bonvecchi 2010; Cetrángolo O. and Jiménez 2003; Stein 1999b; Tommasi, Saiegh, and Sanguinetti 2001). By 2000, the debt doubled and tripled overnight for provincial and city governments. Because of 
international creditors demanding loans to be transacted in American dollars, with the pegged exchange rate and pesofication caused hyperinflation (U.S. Department of State 2011).

The situation became exacerbated under the leadership of UCR President De la Rúa (1999-2001). In late 2001, De la Rúa forced a bank holiday (Corralito) and took private savings and pensions from state banks to pay down the national debt to international creditors. Consequently, this action spread further fear within the international credit markets, pushing more inflation. Without the ability to retrieve personal funds from the bank and increasing prices for basic foodstuff, Argentina's economy became unstable. Robbing and looting became commonplaces across Argentina's cities in November and December of 2001. As one way to pacify the hungry, soup kitchens (Cacerolazo) emerged in the streets. Within Buenos Aries, women began to protest the adverse effects of the federal policies by banging wooden spoons onto pots on street corners each evening (Hopkins 2002). This climaxed when the country defaulted on its national debt in December 2001. The ill fate of the economic crisis in late 2001 caused protesting in the streets, which left 28 people dead (U.S. Department of State 2011).

Argentina's economic predicaments triggered social unrest and political turmoil. De la Rúa was forced out of office, which was followed by the designation of several interim presidents that served short stints in the Casa Rosada, Argentina's presidential palace. Finally, a legislative assembly elected Eduardo Duhalde (PJ) president in 2002 to complete the term of former President De la Rúa. After assuming the presidency, Duhalde formally reversed the Convertibility Law. He stabilized the social situation and advanced presidential elections by six months to pave the way for a new president to be 
elected with a popular mandate (Hornbeck 2002; U.S. Department of State 2011). Duhalde did this by changing the tax code five times including exemption items such as reducing social security contributions and increased personal asset tax rates while changing federal required taxes for farmers. These included the elimination of the VAT for honey producers, reducing the VAT for cattle producers and suspending the differential VAT for all agrarian activities (Bonvecchi 2010). All these fiscal reforms consequently increased the de-facto power of the central government.

\section{Recent History of Centralization}

By 2002 most of Argentina's financial systems had been devastated. The economic crisis encouraged the national government to implement several pressing financial reforms such as the federal pact, the role of the budget and taxation policy. While some scholars have focused on political-institutionalist and political-economic types of analysis for how reform took place (Benton 2009; Eaton 2004), others have focused on what types of reforms are necessary in this type of post-economic crisis (Bonvecchi 2010; Tommasi, Saiegh, and Sanguinetti 2001). Some suggest these financial reforms for Argentina, and Latin America in general, should consider counter-cyclical fiscal policies, hard versus soft budget constraints, encourage debt limits, and promote market-preserving federalism (Bonvecchi 2010; Santiso 2005; Tommasi 2002; Treisman 2007; Weingast 1995; Weingast 2006).

Within the past 20 years, Argentina has made its fair share of reforms. Of the 16 budget area reforms, six have aimed at introducing structural changes to the rules of the game. They include the 1992 Financial Administrative Law; the 1996 Second State Reform; the 1997 budget's prohibition to finance increase expenditures through the 
Treasury obligations funds, the 1999 Financial Solvency Act; the 2005 budget's reversal of the prohibition introduced in the 1997 budget; and the 2006 Reform of the Financial Administrative Law. According to Bonvecchi (2010) the rest of the laws were piecemeal. "Fiscal reforms in Argentina have generally consisted of adapting revenue-sharing results to restrictions imposed on the federal and provincial treasuries by either economic shocks or stabilization policies" (Bonvecchi 2010). For most of the 1990s and 2000s the national government centralized control under the PJ leadership by using these transfers.

In 2003, Nestor Kirchner (PJ) won the presidency defeating former President Menem with the majority after a runoff election. He quickly restored the economy and the country found positive growth rates. Although Kirchner enjoyed approval ratings of more than 60 percent, he announced in July 2007 that he would not seek re-election and backed his wife, then-Senator Cristina Fernández de Kirchner, as the candidate to succeed him (U.S. Department of State 2011). Fernández de Kirchner had previously served in the Chamber of Deputies and the Senate. She won 45 percent of the vote in the October 2007. Three year later her husband died of a fatal heart attack in 2010 leaving her to be alone in power.

The economy has improved with the Kirchners' presidencies. Both Cristina Fernández de Kirchner and Nestor Kirchner are associated with the recentralization of Argentine's public finances. Budget officials noted that it is difficult to follow Argentina's budget process since it has changed so many times in recent years. For example, "fix sums, tax-reduction deferrals, and bailouts have allowed the provinces to maintain their status quo spending abilities at least until the following negotiation" with the federal government (Bonvecchi 2010). The municipal treasurers often manipulate 
accounting measures and codes to maximize revenues streams and increase transfers during the fiscal year. It has been acknowledged that both Kirchners have managed to artificially keep the inflation rates low by politically controlling the federal statistical agency, the Instituto Nacional de Estadísticas y Censos (INDEC). One reporter stated:

Economists say the official inflation rate of 8.5 percent in 2007 was really about 25 percent. In the 12 months ended this June, the INDEC put the rate at 5.3 percent, but economists say it might be three times higher. Argentina's vaunted economic growth this decade might have been exaggerated, too. Credit Suisse said the 7 percent expansion the government reported last year is likely 2 to 3 percent lower (Forero 2009).

This type of data manipulation increases uncertainty, making citizens (and SNG officials) untrustworthy of official statistics or budget information.

In March 2008, with a majority in Congress, Kirchner introduced a new slidingscale taxation system for agricultural exports, effectively raising levies on soybean exports from 35 percent to 44 percent (U.S. Department of State 2011). Known as the "retenciones" or withholdings by the agricultural commodities, this tax alone caused major protesting in the streets by landowners, some of the wealthiest Argentines. The creation of this tax alone demonstrates how the Kirchners' government has centralized its power to manage a larger share of the tax efforts (The Economist 2008). The federal government created new taxes to increase its share of revenue; in turn they claim new programs that the administration has provided to local cities and towns. One journalist reported the following statement:

To support her campaign, Mr. Kirchner ramped up spending on pensions and public works. The new government is seeking to restore the fiscal surplus to rein in the resulting inflation. So it has raised the already steep export taxes it levies on most agricultural commodities. The rate on soybeans, to take the most extreme example, has been hoisted to 40 percent, up from 27 percent last year" (The Economist 2008). 
Figure 4.2 Argentina's Tax Labyrinth

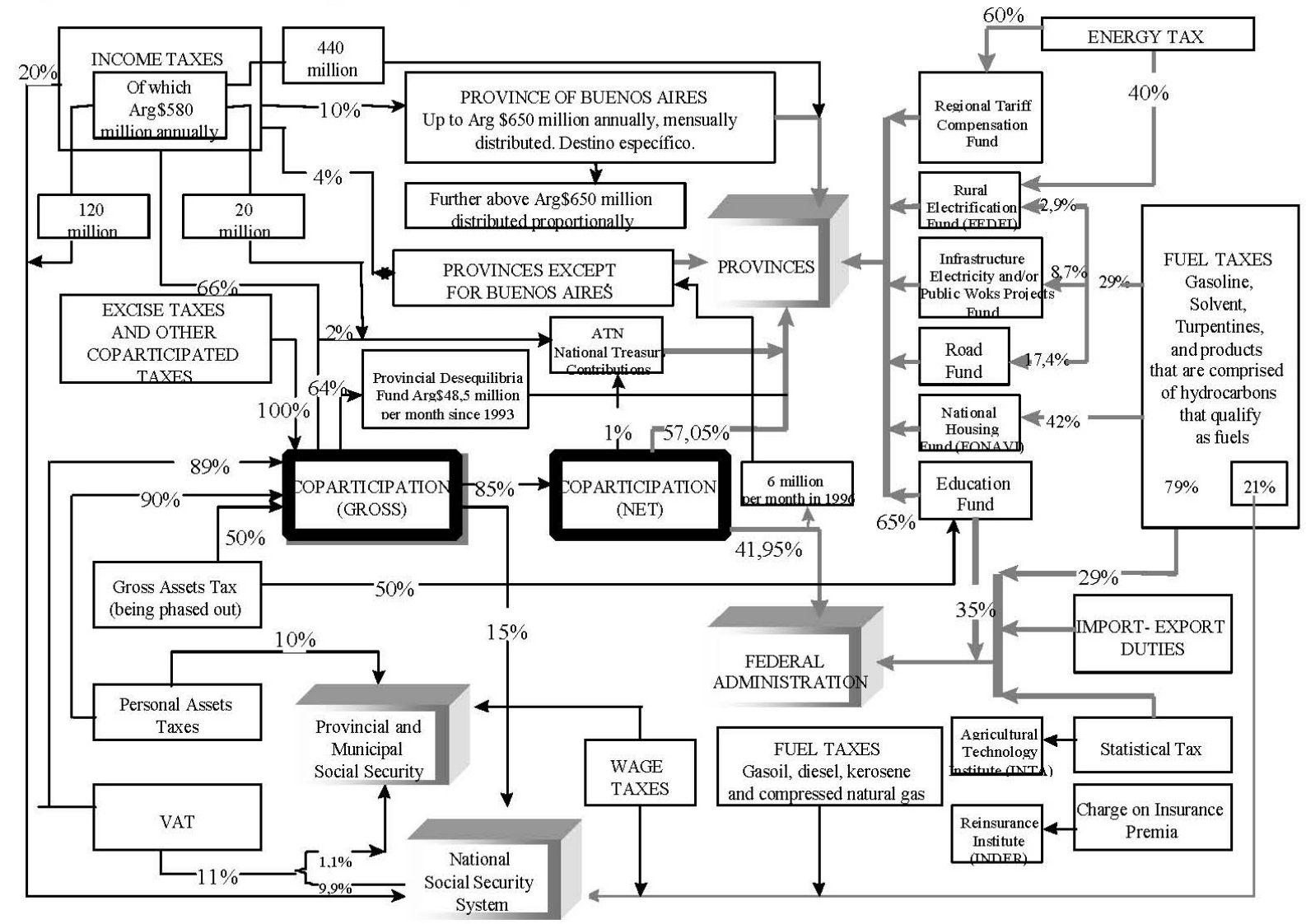

Source: (Tommasi, Saiegh, and Sanguinetti 2001)

Figure 4.2 outlines the Argentine tax system. Often called the "tax labyrinth," since it shows where resources originate from the various taxes and fees and how they are redistributed to the provinces of at varying percentages. For example, the federal government receives 41.95 percent of its revenues from the net co-participation funds and 35 percent from taxes such as fuel, import/export duties and other outside funds. The revenues from the provinces, which collect most of the taxes from excise taxes, income, gross assets, personal assets taxes and the VAT, is put into the co-participation gross fund and then re-distributed again depending on the fiscal pact to the federation, provinces, and the federal district (which is set forth in Table 4.1). 
Table 4.3 illustrates Argentina's percentage of GDP disaggregate by tax source from 2001 to 2008. The graph shows a low percentage of property taxes, less than three percent annually, and the steady increase in VAT, collected at the national level. According to the literature in public finance, the VAT has a regressive nature and the property tax is progressive (Birdsall, De La Torre, and Menezes 2007). In general, the entire tax net has increased and become more regressive from 2001-2008. The overall central tax collection has increased from 21.14 percent in 2001 to 31.01 percent in 2008 . The highest percentage was 39.35 percent tax collection during 2007, which can be explained by the high commodity prices and the economic boom that Argentina experienced during that year with increase taxes on agricultural exports.

\begin{tabular}{|c|c|c|c|c|c|c|c|c|c|}
\hline Concept & Concept & 2001 & 2002 & 2003 & 2004 & 2005 & 2006 & 2007 & 2008 \\
\hline \multirow[t]{7}{*}{$\begin{array}{l}\text { I. National } \\
\text { Taxes }\end{array}$} & $\begin{array}{l}\text { Rents and Capital } \\
\text { Gains }\end{array}$ & 3.99 & 3.04 & 4.30 & 5.26 & 5.49 & 5.31 & 5.44 & 5.30 \\
\hline & Property Tax & 1.43 & 1.77 & 2.03 & 2.13 & 2.15 & 2.14 & 2.22 & 2.26 \\
\hline & VAT & 8.09 & 7.13 & 7.71 & 9.04 & 8.95 & 9.05 & 9.42 & 9.43 \\
\hline & $\begin{array}{l}\text { Commercial Services } \\
\text { and International } \\
\text { Transactions }\end{array}$ & 0.64 & 2.05 & 3.03 & 3.05 & 3.07 & 3.07 & 3.41 & 4.39 \\
\hline & Other & 0.13 & 0.09 & 0.08 & 0.15 & 0.16 & 0.21 & 0.14 & 0.15 \\
\hline & Social Security & 3.23 & 2.83 & 2.83 & 3.04 & 3.27 & 3.78 & 4.51 & 5.09 \\
\hline & $\begin{array}{l}\text { Subtotal National } \\
\text { Taxes }\end{array}$ & 17.50 & 16.91 & 19.98 & 22.67 & 23.10 & 23.57 & 25.13 & 26.63 \\
\hline \multirow{4}{*}{$\begin{array}{l}\text { II. Provincial } \\
\text { Taxes }\end{array}$} & Property Tax & 1.18 & 0.97 & 1.09 & 1.10 & 1.10 & 1.03 & 0.97 & 0.96 \\
\hline & Goods and Services & 2.08 & 1.97 & 2.35 & 2.58 & 2.74 & 2.82 & 2.97 & 3.21 \\
\hline & Other & 0.37 & 0.46 & 0.37 & 0.35 & 0.28 & 0.32 & 0.28 & 0.22 \\
\hline & $\begin{array}{l}\text { Subtotal Provincial } \\
\text { Taxes }\end{array}$ & 3.64 & 3.39 & 3.81 & 4.04 & 4.12 & 4.17 & 4.22 & 4.39 \\
\hline \multicolumn{2}{|c|}{ Total Collection } & 21.14 & 20.30 & 23.79 & 26.70 & 27.22 & 27.74 & 39.35 & 31.01 \\
\hline
\end{tabular}

\section{Problems with the Inter-Governmental System}

Argentine provinces have heterogeneous populations and economic development efforts. There is a great deal of differences between size, population density and 
economic activity between provinces (Bonvecchi 2010). This has created major structural problems creating obstacles for Argentine federalism. For example, in Argentina regional disparities and redistribution of resources for the province of Santa Cruz's has income per capita (IPC) of 8.6 times higher than that of Formosa. This is compared to Canada, where the difference between the richest and the poorest state is 1.7 IPC (Cetrángolo O. and Jiménez 2003). Debt control, the aggregate deficit problem and macroeconomic policy have led Argentina to become more centralized.

Argentina has a very complex and arbitrary federal co-participation law. ${ }^{12}$ National transfers are only a portion of the revenues collected from certain federal taxes, which include personal and corporate income taxes and the VAT (Brown, Díaz Frers, and Koola 2006). In tax revenue sharing there are several other mechanisms by which the federal government transfers revenues to the provinces, despite the constitutionally granted power of local governments to institute their own direct taxes. For example:

The co-participation system has been severely criticized for 1) a high degree of vertical disequilibria; 2) extreme complexity and lack of transparency; 3) arbitrary distributions; 4) absence of debt limits; 5) federal bail-outs through ad-hoc agreements; 6) repeated breaking of commitments by the federal government and the provinces; and 7) the absence of a federal fiscal or judicial institutions to solve these conflicts (Brown, Díaz Frers, and Koola 2006).

Overall, the co-participation system has produced funding difficulties among the different levels of government as well as abundant opportunities for corruption via the discretion used to distribute resources among the provinces.

\footnotetext{
12 Public financial officials have what is called the Tax Labyrinth map. The graphic is filled with lines, boxes and arrows. It shows where taxes are divided into percentages, which changes depending on whether it is diverted to the national or provincial governments. Provincial governments often copy the map and apply it to their city governments and metropolitan areas.
} 
In summary, the financial disasters of 1989 and 2001 hit Argentina hard. Both times the result was the ousting of democratically elected presidents for new ones and reorganizing the inter-governmental relations of the country. One IDB report suggested following:

Economic shocks, such as the 1989-91 hyperinflation and the 1998-2002 recession, and stabilization policy shocks, such as the Convertibility Law and the 2002 devaluation and pesoification of contracts, have triggered the initiation of reform processes in all fiscal areas and encouraged the introduction of reforms aimed at the consolidation, hierarchization, and centralization of resources and their management at the national level. But the passage of these reforms has not prevented the continuous extraction of compensation from the federal government by the provinces (Bonvecchi 2010: 122).

The inter-governmental division of work post-2002 re-centralized Argentina through three may policy shifts: 1) through the rescue packages sent for provincial debts; 2) through the introduction of national co-participation taxes; and 3) by decreasing subnational sovereignty (Cetrangolo and Jimenez 2003). The end result of these changes has created political conflict and general institutional weakness throughout Argentina's federation. Thus this has created serious stains on meeting public policy goals at all levels of government. Much of this has revolved around the concept of debt management and macroeconomic indicators (Eaton 2004). These policies have not been consistent. For instance, "between 1988 and 2008, tax legislation was changed 83 times, fiscal federal rules 14 times, and budgetary institutions 16 times" (Bonvecchi 2010: 122).

Cetrangolo and Jimenez (2003) suggest that there are four observable consequences from Argentina's Fiscal Pacts in regards to their inter-governmental relations. First, there is an incentive problem for local municipal governments to collect more taxes. Second, there are tax liabilities for those provinces that collect more taxes (such as Santa Fe, Buenos Aries, Cordoba, and Mendoza). Third, there is lack of capacity to find new 
revenue sources and nearly no accountability of spending at all levels of government. Finally, there are also distributional conflicts for selecting which province receives finances for public projects, which also is exacerbated by the weak political institutions. For example, policymakers have wide-ranging political discretion on funding sectoral policies such as health and education as well as to create emergency arrangements, which may impact on quality of inter-governmental relations.

To summarize, Argentina was a loosely decentralized federation of caudillos for most of the 19th and 20th century; only when Peron came into power for the first time in the 1940s did the federation become more centralized. He was responsible for creating a strong role for the central government, which provided public services to workers and peasants and allowed other disenfranchised people into the political system. Traditionally land-owning elite were the main representatives from the provinces to the national government, therefore with a strong role of the central government has created tension between these two groups. Argentina's recent history has been a downward spiral of military dictatorships, presidential coups, and economic crises. From 2002-2010, when Argentina's democracy stabilized under the Kirchners, the central government has continued to have similar power struggles between the provinces and the presidency. The president's office has favored a stronger role for the executive branch of government. This may be seen, for example, by Kirchner's advocating for more federalism, but have also introduced several new national level taxes, such as the retenciones tax, which gives the national government more fiscal authority. Overall, Argentina has generally become more centralized, but this is very difficult to decipher since there has been so many other political and economic events to overcome. 


\subsection{Mexico}

In contrast to Argentina, federalism in Mexico began as a short-term solution to the conflict that led to the declaration of independence in 1821. According to historical accounts by Merino (2010), "this was not the result of a pact between autonomous entities, nor the product of evolution, characteristic of regions with a strong tradition of self-government, but [the unification of the states] was rather an appropriate institutional offer to maintain cohesive political elites who had ruled the states during the late colonial period of the country" (emphasis in the original). For him, Mexico's federalist system itself was born out of conflict between the Federalist-Liberals and the CentralistsConservatives.

The consolidation of the modern Mexican State finally arose with the Mexican Revolution (1910-1920). For most of the 20th century, the national government was built upon the PRI's political machine and followed the ideology of the revolution. The revolution triumphed when the country could replace the apparatus of domination of Porfirio Díaz (1876-1911) by a unique set of political and administrative institutions. The dominance of the center was imposed on any regional political aspirations. The creation of the political party Partido Nacional Revolucionario (PNR), the original name of the current Partido Revolucionario Institucional (PRI), in 1929 had the intent to build an allencompassing organization which allowed any individual, region or group to be incorporated into the policy decision-making process. The PNR was later transformed into the Partido de la Revolución Mexicana (PRM) in 1938. In 1946, the PRI (its acronym today) was created as the principal organization that served to centralize power in Mexico. Given the fact that most of the political conflict during the Díaz era and the 
years after the revolution exploded (1910), the political machine's principal objective was to build a mechanism to reduce conflict between local leaders and the President, who was considered the main caudillo with total power and authority. Prior to the foundation of the PNR, President Plutarco Elías Calles (1924-1928 and de facto leader until 1935) described the pattern of Mexican politics at the time as a way "to lead Mexico towards true institutional life, it must first pass through a historical period of a 'one man Nation' to become a nation of law and institutions" (El Colegio de México 2009: 33). Yet it was not until the Presidency of Lázaro Cárdenas (1934 to 1940) that the final consolidation of the party occurred.

For most of the 20th century, federalism was a constitutional formality with no practical implementation. What followed was the systematic concentration of constitutional powers in the Federal Executive, accompanied by the concentration of resources and decisions, under the political party apparatus of the PRI. State governments controlled local and municipal councils (Diaz-Cayeros 2006). As a result of the national dominance of the PRI in all legislative Congresses, its policies and presidential initiatives became automatically legitimate, while Federal District's (Districto Federal—DF) government was also subordinated to the presidency of the republic. Under full control of the government at all levels, the political machine of the PRI led the country for more than 70 years $(1929-2000)$.

\section{History of Fiscal Centralization}

In the aftermath of the Mexican Revolution (1910-20), the state, political power and the tax regimes were fragmented. The 1917 Constitution established that taxes could not be levied by states. The states collected taxes on rural property, trade, industry, 
agriculture, and livestock, and they were reluctant to give up any resources. That reluctance to cede any tax authority to the federal government made it a challenge to unify a national fiscal system (Figueras-Zanabria 2006).

In 1925, the finance secretary convened the first National Tax Convention (NTC) with the objective to unify the tax system and to create a permanent body to solve problems affecting the national economy. At this event, the SNG purposed to eliminate local taxes that duplicated federal ones (Diaz-Cayeros 2006). In the new system, the states would collect their revenue shares directly and if disagreements occurred they would not be dealt with on the Congressional floor, but rather a technical body would review complaints. In Congress the proposal was discussed and rejected by the fiscal committee. According to Figueras-Zanabria (2006), the first call for the NTC was successful in two ways: first, it introduced the idea that fiscal debates were intended to be technical rather than political, and second, it introduced the idea of eliminating Congress from influencing fiscal debates, thus depoliticizing them. This allowed the federal government room to negotiate with the states without the Federal Deputies discussing fiscal deals, which ultimately enhanced the executive authority over the process. It was not until the PRI lost control of the Congress in the late 1990s that Congress recovered the authority to make financial decisions (Figueras-Zanabria 2006).

Between 1929 and 1931 the national government began to arrange fiscal agreements between each individual state government. The federal government managed to establish fiscal agreements implementing coordination assignments on specific taxes with some states. The second NTC took place in 1933 but there was more political division than at the first meeting (Figueras-Zanabria 2006). The focus of debate was 
divided on the topic of exports, economic support and land reforms. The discussion remained around the 1929 fiscal crisis and the requirement of the federal government to provide economic support to the states. Because property taxes were a main revenue source for states, land redistribution into communal property (ejidos), which was tax exempt, created divisions. Those federal deputies closer to the President were in favor of these land reforms, while other states were not. With the implementation of the law, some states revenue base was severely damaged.

It was not until the second and the third conventions, in 1933 and 1948 respectfully, that the federal government gradually took over the main revenue sources of the country (Figueras-Zanabria 2006). By dividing different taxes by the levels of government, a better mix of fiscal federalism was determined. In 1942, the constitutional reform granted the federal government exclusive tax authority over foreign trade, natural, and energy revenues, financial institutions and public services. The federal authorities were also given a "special right to tax" the production and consumption of tobacco, petrol, and oil derivatives, matches, "aguamiel," a liquor made from cactus, and forestry exploration (Diaz-Cayeros 2006; Figueras-Zanabria 2006). President Cardenas claimed authority of these revenues, forcing states to share federal taxes, when he came into power and consolidated the national political party PNR (Partido National Revolucionaria, a precursor of the PRI). With the PNR's control of the state and national legislatures, they also controlled the regional area's political affiliation. Arguably, through the hierarchical party leadership structure, political careers were created. Party obedience, not interest groups participation or meeting constituency demands, was rewarded. As one result, politically subordinated states gave away their fiscal authority in exchange for 
unconditional transfers (Diaz-Cayeros 2006; Figueras-Zanabria 2006). Finally, at the 1948 NTC convention, the authority to tax was reflected in the new federal proposals, proposals that appeared in Congress without opposition.

The unified fiscal coordination was finally established in the 1940s with the installation of the federal sales tax, and later also included the income tax. Eventually, additional taxes were added into the fiscal coordination laws negotiated between the national and state governments. For example, the national sales tax (impuesto sobre ingresos mercantiles-ISIM) was introduced. Initially set at a rate of three percent nationally, if states agreed to the compact they could keep 1.2 percent of the total; however, they also had to agree to eliminate their internal trade and industrial tax. In 1953, the first Law of Fiscal Co-ordination was issued, establishing a single federal income tax (impuesto sobre la renta-ISR). With this reform, seven more states finally joined the fiscal system in 1973 (Figueras-Zanabria 2006). As states joined the federal system, they relied more heavily on fiscal transfers rather than their own resources to manage their state budgets. "Between 1950 and 1975, the percentage of tax revenue by states dropped from 20 to less than ten percent" of their total budgets (Figueras-Zanabria 2006:61).

By the late 1970s, Mexican President Lopez Portillo was known for saying, "In the world economy, countries are divided in two: those that have oil and those that don't have it. And we have it!" (emphasis in the original). Since the 1970s, Mexico has behaved as a Rentier State. ${ }^{13}$ Farfán-Mares (2010) argued that because of the high oil revenues, between 1976 and 2010, the Mexican state could severely reduce taxes, even while

\footnotetext{
13 Rentier States are defined in the literature as countries, which are intensively dependent on oil exports to finance the government (Beblawi and Luciani 1987b). Often Rentier States are associated with negative outcomes, and the literature often addresses this as a curse.
} 
providing many social benefits to citizens. For much of this time, Mexican State finances have depended on oil revenues. ${ }^{14}$ During periods of high oil prices, the states yielded even more power to the national government. For example, in 1979 Congress passed the new Law of Fiscal Co-ordination (LCF), which effectively did two things. First, the law created the national System of Fiscal Coordination (SCF) and, second, it replaced the national sales tax (ISIM) with the VAT. Arguably, because of the oil bonanza, the national government could manipulate the state governments by increasing federal revenue authority while providing additional transfers to state and local governments. According to Article 27 of the Constitution all subsoil resources are managed by the federal government, thereby states and municipalities have no tax authority over them. The oil boom helped to strengthen the national government, by centralizing revenues and decentralizing expenditures for public services such as education, health, and public security.

Although political democratization and the change in the Presidency were in place, the oil resources provided by the federal government greatly increased its authority. States and municipalities received increasing amounts of resources building negative incentives toward local and state taxation. Only the state governments with more tax collection and competent administrations "resisted" oil abundant transfers (Farfán-Mares 2010). The support for the one-party regime under the PRI was fueled by oil, and thus not until the democratic transformation in 2000 was there a new fiscal transformation of the state.

\footnotetext{
${ }^{14}$ Farfan-Mares claims that in 1921 Mexico was the ranked second among the world's producers (just after the United States) but from 1924 onwards Mexico declined as a major producer (falling to the fourth place). It was not until 1981 that exports multiplied 23 times from its rates in 1974. Production continued to increase from $653,000 \mathrm{bpd}$ (1974) to 2,748,000 bpd (1982), peaking to 3.5 million barrels per day between 2003 and 2004 (Petróleos Mexicanos 2008).
} 


\section{Return to Democracy}

It is argued that the decentralization of the Mexican state caused the democratic transition of 1983-2010 (Selee 2006). The one party lead by the PRI began to change in 1983 when subnational governments selected opposition parties (notably Guanajuato was one of the first PAN governments to win state level elections in 1991). It was not until 1988 that political pluralism began, and electoral reforms soon followed. From 1994 to 1997 the political system changed substantially, which included reforms to the country's electoral system and the political party composition of local governments, the state Congresses, the Chamber of Deputies and the Federal District government (Mexico City). In 2000, the national government changed from PRI party leadership to PAN as Vicente Fox became the president of Mexico (Selee 2006).

The most notable fiscal reforms were made to article 115 of the national Constitution in $1983 .{ }^{15}$ The reform assigned municipal government with responsibility of portable water, drainage, and sewerage systems, public lighting, tax collection, public markets, cemeteries, slaughterhouses, streets, public parks and public safety. This reform coupled with President Salinas' (1988-1994) new federal poverty alleviation program called the Programa National de Solidaridad (PRONASOL), which provided public funds for basic infrastructure at the municipal level. These were the first to be decentralized and transferred to the local level. Salinas also decentralized education expenditures to the states in 1993. The states were responsible to manage these policies.

\footnotetext{
15 The fiscal federalism system in Mexico is the result of the creation of National System of Fiscal Coordination $(S N C F)$ in 1980. Although in principle, the Mexican Constitution establishes a formal distribution of fiscal sources for each tier of government, in practice, the SNCF guides the distribution of resources between tiers of government. (Raich, Uri. 2002. "Impacts of Expediture Decentralization on Mexican Local Governments." Pp. 44. Mexico City: Budget and Public Expenditure Program at the Centre of Research and Teaching of Economics (CIDE).
} 
Similar to Salina's education decentralization effort, Zedillo also decentralized health expenditures to the state in 1998. In that year, Mexico's Congress also approved a no bailout law for the subnational governments.

\section{Fiscal Decentralization Reforms}

The fiscal and governmental structure was not transformed overnight. It gradually changed during the 1980s. A federal tax system was created under President Miguel de la Madrid (1982-1988) in which states collected revenues and sent them to the National Treasury, whereby the National Treasury re-distributed the funds back to the states according to a formula. ${ }^{16}$ If a state did not send its full tax collections to the National Treasury, it was penalized by a reduction in Federal Revenue Shares (FRS). If a state refused to abolish some of their own taxes, such as sales, trade or otherwise they were expelled from the FRS system. This highly incentivized states to follow the FRS system. Under the FRS system, the Supreme Court decided any disputes or unauthorized states' claims. The federal government created the National Institute for the Technical Strengthening of the Subnational Finances (INDETEC) as an independent agency to provide technical advice as the FRS governing body. Essentially, the Mexican states gave up their power to tax once they became part of the federal coordination system. Since the federal government managed their bases, rates, and administration, they were in control of virtually all of the nation's public finances. Figueras-Zanabria (2006) identified those state taxes, which were abolished by the FRS since 1980. They are listed in table 4.4.

\footnotetext{
16 The Fiscal Coordination Law (LCF), Chapter III, art 15 has this equation. There are several people, both in academia and public policy officials who claim that the formula is not working to promote equity across the states.
} 
Table 4.4 State Taxes Abolished Since 1980

1) Entertainment and public shows

2) Property transfers and other real estate operations

3) Income from professionals and lucrative activities

4) Capital yields

5) Trade of motor vehicles between private parties

6) Promotion, dilation, and trading of alcoholic beverages

7) Premises for the selling of alcoholic beverages

8) Real estate leasing

9) Fees

10) Petro and oil derivatives purchase

11) Livestock exploitation, slaughtering, trading, and shearing

Source: Based on information from INETEC (1998)

Not until the PAN began to win subnational elections did a debate about the national distribution of fiscal responsibilities begin. New political dynamics began at the national level, once the opposition political party began to win local elections. This first happened when President Carlos Salinas (1988-1994) allowed an opposition party member to win the gubernatorial election in the State of Baja California in 1989. ${ }^{17}$ This was a surprising result, as the PRI often "resorted to all manner of both legal and illegal means to win election: fake voter registration lists, ballot box stuffing, disqualification of poll-watches, even intimidation by making sure that there was a prominent military presence at conflicting polling stations" (Figueras-Zanabria citing Cornelius 1987: 77). Salinas was notorious for ousting governors, sacking more than any other PRI president, as another way to control the state governments within the federation.

17 After many fraudulent elections, it was not until the victory of the PAN in Baja California that President Salinas accepted his first opposition candidate winning the election. But he did not accept the victories of the PAN in Guanajuato, whose winner was Vicente Fox, nor in the state of Michoacán where the PRD won. Some suggest that it was because Michoacán was the birthplace of Cardenas, an important left-leaning PRI politician at the time. It was again in 1991 in San Luis Potosi that an opposition candidate representing the PRD won, but the President imposed Fausto Zapata in his place. Salvador Nava, the victim of the electoral fraud by the PRI went on a hunger strike in the Zocoalo, center of Mexico City, until he was deemed the winner. That same year, President Salinas with support by both the PRI and the PAN passed a law that allowed the state to burn the ballot boxes from the 1988 Presidential election, which was also deemed fraudulent. 
After the win in Baja California, the PAN had further victories in Aguascalientes, the Federal District, Guanajuato, Jalisco, Michoacán, and Morelos. After fierce protest of fraud in 1991, interim governors replaced "elected" PRI governors in Guanajuato and San Luis Potosi (Figueras-Zanabria 2006). The federal government did not acknowledge the left-leaning PRD (Partido Revolucionario Democratico) wins as readily as the rightleaning PAN victories. The parties knew they needed to become allies in order to beat the PRI in future presidential elections and create a coalition in Congress to change economic policies.

The Salinas administration was faced with two significant challenges. First, it faced large oppositions within the country, and second, it wanted to be viewed as democratic, open, and honest, especially by the international community. This was occurring at a time when structural adjustment programs and neo-liberalism policies were dominant in Washington, D.C. and seen as the best alternative to improve developing economies. Salinas understood that fiscal decentralization would empower local political actors but also encouraged political fragmentation (Figueras-Zanabira 2006).

As a result, Salinas created a new federal program for poverty alleviation called PRONASOL, which included funds for municipal development for basic infrastructure projects such as water, sewerage systems, and electrification (Moreno 2004). Although PRONASOL allocated funds for communities to co-work and manage those resources, federal discretion, electoral-biased criteria, and central oversight over those resources were strong. Salinas also decentralized the education expenditures to the states in 1993.

"The Municipal Funds constituted around 14 percent of the total Solidarity [also part of PRONASOL] budget" (Selee 2006:88). Although at first view this was a major 
increase in municipal revenue, it was clearly a de-concentration of wealth for municipalities to provide functions already listed in the 1983 Constitutional Reforms. The PRONASOL funds represented an increase in the state's dependency on federal transfers to perform their basic functions (Rodriguez 1997; Selee 2006; Ward and Rodriguez 1995). Figure 4.3 presents the differences between local finances and national transfers. The dark black line represents own-source revenue collected by Mexico's subnational governments and the light gray line represents the transfers from the Federation to the states.

Figure 4.3 Difference between Mexico's Municipal Revenue and Federal Transfers

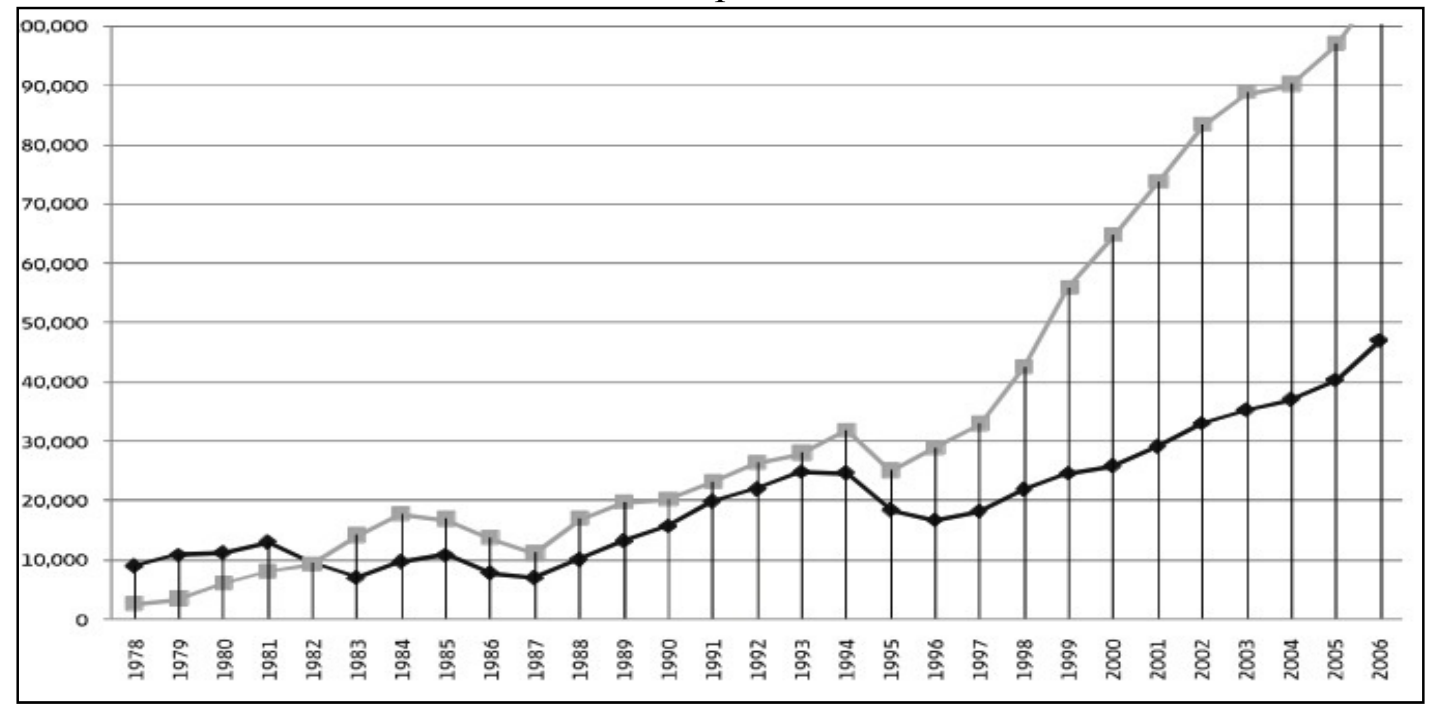

Source: Merino-Huerta (INEGI data 2008) measured in thousands of pesos.

Additionally in 1990, Salinas made three major policy reforms related to Mexico's fiscal policies. First, his administration changed the formula for how the funds were to be distributed to state governments. The reformed formula would be determined by the following criteria: population, level of economic development and tax collection efforts. A compensatory fund would be allocated inversely to the population with the highest amount of poverty and lowest amount of local own-source tax collection. Second, Salinas's administration consolidated the complete tax collection process by introducing 
additional VAT. The tax resolved the problem that the local administrations (at the state and municipal level) were generating too few revenues overall, which jeopardized the total tax revenues collected (Figueras-Zanabira 2006). Finally, and most notably, Salinas' major accomplishment was the signing of the NAFTA agreement, which boosted domestic support of his economic reforms. ${ }^{18}$ This covered up the internal disputes to international audiences.

The government of President Ernesto Zedillo (1994-2000) was rather unsuccessful at home and abroad with its policy reforms (Figueras-Zanabria 2006). With the uprising of the Chiapas guerrilla movement led by Commandant Marcos in 1994, the world observed Mexican politics even more closely. Zedillo's principal goal was to maintain political control through his federal program called "New Federalism." According to many scholars, Zedillo's federal reforms ended the centralized power structure that the political system maintained and controlled (Rodriguez 1997; Selee 2006; Ward and Rodriguez 1995). This single reform transformed the federal government and its subordinating relationships to the states and municipalities.

Fiscal policies under Zedillo's "New Federalism" plan included modification of already existing federal funds (expenditures) while changing the Law of Fiscal Coordination or how some taxes were collected (revenues). First, his administration took Salinas' PRONASOL social funds and converted them into a single line item in the federal budget for social development (Ramo 26). ${ }^{19}$ This new budget item was designed

\footnotetext{
18 NAFTA is the North American Free Trade Agreement, which was signed in 1994 by the United States, Canada and Mexico.

19 A Ramo in Spanish means budget item. Each major support fund in the Mexican budget has a specific number and is known for that number.
} 
on the basis of poverty indicators and only contributed resources to the neediest states. ${ }^{20}$ In 1996, this fund was modified once again, and the Fund for Individual Priorities of States disappeared. The Federal Fund for the State and Municipalities (Ramo 33) was created in its place in 1997. These funds were created to be compensatory for poorer states to promote economic development. Local governments also receive Ramo 28 (also called Participaciones), which are standard mandatory unconditional transfers to the states in the federation. Table 4.5 provides a description of the federal transfers and how the Federal government distributes them to the states.

\begin{tabular}{|c|c|c|c|c|}
\hline Concept & $\begin{array}{l}\text { Shares Federal } \\
\text { (Ramo 28) }\end{array}$ & $\begin{array}{l}\text { Shares Federal } \\
\text { (Ramo 33) }\end{array}$ & $\begin{array}{l}\text { Federal Revenue } \\
\text { Surplus }\end{array}$ & $\begin{array}{l}\text { Resource } \\
\text { Reallocation } \\
\text { Agreements }\end{array}$ \\
\hline Distribution & $\begin{array}{l}\text { Resources } \\
\text { distributed } \\
\text { according to the } \\
\text { provisions of } \\
\text { the Budget Act } \\
\text { and Fiscal } \\
\text { Responsibility }\end{array}$ & $\begin{array}{l}\text { Funds } \\
\text { distributed by } \\
\text { formula and } \\
\text { criteria } \\
\text { established in } \\
\text { the Fiscal } \\
\text { Coordination } \\
\text { Law }\end{array}$ & $\begin{array}{l}\text { Resources } \\
\text { distributed } \\
\text { according to the } \\
\text { provisions of the } \\
\text { Budget Act and } \\
\text { Fiscal } \\
\text { Responsibility }\end{array}$ & $\begin{array}{l}\text { Resources } \\
\text { allocated in } \\
\text { accordance with } \\
\text { the provisions of } \\
\text { the conventions } \\
\text { themselves }\end{array}$ \\
\hline Designation & $\begin{array}{l}\text { The funds are } \\
\text { not labeled } \\
\text { expenditure }\end{array}$ & $\begin{array}{l}\text { The resources } \\
\text { have cost labels } \\
\text { established in } \\
\text { the Fiscal } \\
\text { Coordination } \\
\text { Law }\end{array}$ & $\begin{array}{l}\text { The resources } \\
\text { have partial } \\
\text { spending in the } \\
\text { Budget Law and } \\
\text { Fiscal } \\
\text { Responsibility }\end{array}$ & $\begin{array}{l}\text { The resources } \\
\text { have cost labels } \\
\text { established in the } \\
\text { conventions } \\
\text { themselves }\end{array}$ \\
\hline Destination & $\begin{array}{l}\text { Resources in } \\
\text { different } \\
\text { proportions for } \\
\text { states and cities }\end{array}$ & $\begin{array}{l}6 \text { state funds } \\
\text { and } 2 \text { municipal } \\
\text { funds }\end{array}$ & $\begin{array}{l}\text { Resource for } \\
\text { states }\end{array}$ & $\begin{array}{l}\text { State and local } \\
\text { resources }\end{array}$ \\
\hline
\end{tabular}

\footnotetext{
20 In spite of PRONASOL ending by President Zedillo in 1995, the basic policy continued through the Oportunidades Program and PROGRESA, which were described in chapter III.
} 
Aportaciones (Ramo 33) are the conditional transfers, consisting of seven different funds that can be spent only based on the Fiscal Coordination Law. ${ }^{21}$ Cañas García (2011) contends that these funds were designed to be compensatory for the poorer states in order for them to invest in their own development. They were established as a response to the problems of poverty and inequality as a strategy of spending intended to compensate poorer states. ${ }^{22}$ On average, these transfer funds are nearly half of each state's budget. It is part of the government's strategy to affect different dimensions of poverty and inequality, so the fund contributions are divided into conditional funds for education, health, safety, social infrastructure, among other social expenditures (Cañas García 2011).

\begin{tabular}{|l|l|l|l|}
\hline Table 4.6 Revenues Sources of State Budgets & 1997 & 1998 & 1999 \\
\hline & 12.7 & 13.5 & 12.1 \\
\hline Own Revenue (taxes and fees) & 4 & 4.3 & 4.4 \\
\hline Revenue sharing by origin & 33.4 & 34.1 & 34.7 \\
\hline Common pool revenue sharing (FRS) (Ramo 28) & 0.0 & 2.4 & 3.6 \\
\hline Unconditional Federal Contributions & 3.2 & 35.1 & 38.2 \\
\hline Conditional Federal Contributions (Ramo 33) & 36.6 & 1.9 & 1.9 \\
\hline Matching funds & 10 & 8.8 & 5.1 \\
\hline Negotiated and extraordinary transfers & 100 & 100 & 100 \\
\hline Total & \multicolumn{2}{l}{} \\
\hline Source: Based on Couchene and Dias (2000) p. 223 from Figueras-Zanabria 2006 p. 66. \\
\hline
\end{tabular}

President Ernesto Zedillo not only changed expenditure decisions between the federal and state governments, he also changed revenue collections through revisions in the tax code for the VAT, income tax and car and licensing taxes. For example, in 1997

\footnotetext{
21 The seven funds include: Fund for Basic and Normal Education (FAEB); Fund for Health Services (FASSA); Fund for Social Infrastructure (FAIS); Fund for Strengthening Municipalities and Territorial Boundaries and the Federal District (FORTAMUN-DF); Multiple contributions Fund (FAM); Fund to the Technology and Adult Education (AFTE); Fund for Public Security of the States and the Distrito Federal (FASP) and the Fund to the Strengthening of Federal Entities (FAFEF).

22 Cañas García (2011) research focuses on how these funds have increased the wellbeing of the citizens in these states
} 
he re-established the federal law for the tax on new automobiles. Zedillo argued that the potential for inter-state competition would lead to serious fiscal gaps and suggested that the federal government assign the rate, while the states managed the collection. ${ }^{23}$ The new car tax (Impuesto Sobre Auto Nuevo or ISAN) and the car licensing (tenencia) did not become a state tax, but rather would be administered by the state and managed by the federal government. According to one public official, the general fear of revenue loss has prolonged the debate over the decentralization and management of collection of these funds.

According to one of the municipal association, "in 2000, the Ramo 28 represented 38 percent of the state income but for municipalities that proportion went as high as 44 percent" (FENAMM 2003). Arguably, the reforms have raised state government's tax revenues, but the difference of the transfers to local own-source collection is still large. Mexican municipalities can levy some taxes, fees, products, and fines (impuestos, derechos, productos y aprovechamientos). Because of the amendments made to Article 115 in 1983 , municipalities can also levy property taxes.

Table 4.6 indicates the percentage of revenues on average that municipalities receive to manage their local budgets. Zedillo's efforts at decentralization were marked with the increase of transfers to lower levels of government or "expenditure decentralization," while maintaining major control over the revenue collection. Yet

\footnotetext{
23 This debate continues within Mexico and is an issue that is addressed by international investors. The federal government sets the rate for the new car and licensing taxes and State governments manage their collections. In the mid 2000s a new reform was proposed to use these taxes as collateral for state's public debt.
} 
Zedillo faced major opposition in Congress to approve his 1997 budget. $^{24}$ A coalition between the right PAN and the left PRD formed in Congress, ultimately increasing additional gubernatorial seats, which allowed the opposition parties elect Vicente Fox, of the PAN, as president in 2000.

\section{Problems within the Inter-governmental System}

Even as Mexico has become more democratized, many have acknowledged that there are several problems in the inter-governmental system (Cabrera Castellanos and Cruz Mora 2009; Cabrero and Carrera 2002; Cañas García 2011; Figueras-Zanabria 2006; Flamand 2004; Hernandez-Trillo and Jarillo-Rabling 2008; Rodriguez 1997; Santín 2004; Selee 2006). For example, research has suggested that the transfer funds created since 1998 have reduced the incentives of local governments to collect taxes, particularly property taxes, as the most important tax revenue source for municipal governments (Moreno 2004; Raich 2002; Sour 2004; Sour, Ortega, and San Sebastián 2003). Arguably given the choice, a local policymaker prefers to rely on federal transfers to finance public goods, instead of increasing local taxes, especially if it entails a political cost.

\begin{tabular}{|l|l|l|}
\hline Table 4.7 Problems with Mexican Municipal Legal Structure \\
\hline Entity & Problem & Feature \\
\hline Municipal & Council & Underrepresented municipal council policies \\
\hline & $\begin{array}{l}\text { Uniqueness of the } \\
\text { municipalities }\end{array}$ & $\begin{array}{l}\text { There is no Federal recognition of differences } \\
\text { between Mexican municipalities }\end{array}$ \\
\hline & $\begin{array}{l}\text { Short government } \\
\text { terms in office }\end{array}$ & $\begin{array}{l}\text { Three years is not enough to develop a consistent } \\
\text { plan }\end{array}$ \\
\hline & Re-election & There is no re-election of mayors \\
\hline & Participation & There are no formal mechanisms for citizen \\
\hline
\end{tabular}

\footnotetext{
24 Mexico's budget cycle begins in early May, when the ministries communicate the Ministry of Finance their programming budgets. They craft their budgets based on guidelines provided by Undersecretary for Expenditures, Ministry of Finance (MOF) which is released during the second half of June. Expenditure ceilings are provided to all administrative units during July. MOF condenses the ministries budgets into a single document, which must be sent to Congress by September $8^{\text {th }}$. The Chamber of Deputies is the only house that can revise the Federal Executive's Budget Proposal, since the Senate as excluded from that process in 1886. The Federal Deputies have until November 15th to approve the budget.
} 


\begin{tabular}{|l|l|l|}
\hline States & $\begin{array}{l}\text { "Usos y Costumbres" } \\
\text { or local cultural laws }\end{array}$ & $\begin{array}{l}\text { Some states do not recognize the uses and customs } \\
\text { in predominantly indigenous municipalities }\end{array}$ \\
\hline \multicolumn{2}{|l|}{ Source: Alvarado and Ramírez, 2002 and Guillén 2003. } \\
\hline
\end{tabular}

Researchers have analyzed the legal structure of municipalities to determine why

they are not collecting more local own-source tax revenue. Table 4.7 outlines some of the difficulties sub-national governments face in collecting more taxes. For example, several scholars have studied the "flypaper effect," increased use of federal transfers, displaces local revenue generation (Cabrero and Carrera 2002; Raich 2002; Sour 2004; Sour 2008; Sour, Ortega, and San Sebastián 2003). The majority of them have found a correlation between increases in transfers with the displacement of local tax collection. The federal government in Mexico still dominates the majority of decisions regarding the budget, policies, and standards. There is little doubt that Mexican federalism decentralized more revenues with the last 27 years of reforms; state governments now have more sovereignty and freedom than before (Merino Huerta 2008).

State governments now have greater political influence especially because the hegemonic party system is gone. Increasingly, States have used their formal powers granted to them by the Constitution to appeal laws. Municipalities have also benefited from an explicit policy of strengthening its powers and resources, which not only led to reform Article 115 on two occasions (in 1983 and 1999), but has been openly supported by the reforms to the national system of fiscal coordination and a long list of legislative changes. Municipal governments have begun to be a principal institutional player in the operation of public policy at the federal level. Municipal governments now manage more policies such as: urban development planning, granting of building permits from these plans, the provision of public services and the foray into the municipal public security 
detention that have represented a loss of authority for state governors and on many occasions, new sources of conflict with local councils.

\begin{tabular}{|c|c|c|c|}
\hline \multicolumn{4}{|c|}{$\begin{array}{l}\text { Table } 4.8 \text { Constitutional Law Suits by Municipalities to the Federa } \\
\text { Government (1993-2007) }\end{array}$} \\
\hline State & Number of Suits & State & Number of Suits \\
\hline Nayarit & 1 & Hidalgo & 9 \\
\hline Campeche & 1 & Morelos & 9 \\
\hline Quintana Roo & 1 & Guerrero & 9 \\
\hline Coahuila & 1 & San Luis & 10 \\
\hline Baja California & 3 & Jalisco & 14 \\
\hline Querétaro & 3 & Puebla & 16 \\
\hline Yucatán & 3 & Chiapas & 16 \\
\hline Durango & 4 & Chihuahua & 17 \\
\hline Colima & 4 & Tamaulipas & 20 \\
\hline Tabasco & 5 & Veracruz & 25 \\
\hline Aguascalientes & 5 & Nuevo León & 28 \\
\hline Tlaxcala & 8 & Estado de México & 31 \\
\hline Zacatecas & 8 & Sonora & 38 \\
\hline Michoacán & 8 & Oaxaca & 84 \\
\hline \multicolumn{4}{|r|}{ Total 737} \\
\hline Source: (Merin & 2008) & & \\
\hline
\end{tabular}

Table 4.8 shows that there have been over 700 court cases since 1993 from municipalities to the federal government over issues of territorial, taxes or other rights issues (Flamand 2004; Flamand 2005; Merino Huerta 1991; Merino Huerta 2008). According to Merino (2010), Mexican federalism has failed to transcend three problems since its inception: the tax collection process; the competition regime between states; and the dominance of the political apparatus (particularly the PRI) at all levels. Hence, following the renewal of democracy, federalism has also arisen with new conflicts, particularly between the federal executive and state governments and between them and municipal governments. Merino (2010) suggests that there is a zero-sum game to strengthen Mexico's federal and municipal level governance. Each attempted to strengthen federalism; it has weakened the scope of municipal government. Each time the national government offers new ways to govern municipalities; it further weakens the 
autonomy and authority of states. Yet the national government continues to delegate most of its public policies to be managed by local government.

\subsection{Summary Discussion}

This chapter described how Mexico historically has been very centralized and the country increasingly has focused on fiscal decentralization. While Argentina traditionally has been more decentralized than Mexico, the country is now gradually becoming more fiscally centralized. In regards to Argentina, this assumption relating to the levels of decentralization and recentralization is relatively correct. Because Argentina's macroeconomic instability has caused the central government to take a tighter control of its public finances. The national government, particularly with the current administration, has promoted more centralized tax revenue to be collected and managed by the federal government. The numerous reforms have proved difficult to determine the exact levels of fiscal decentralization or centralization that exists within the country.

Mexico is increasingly committing more fiscal transfers to subnational governments for expenditures, but this has not been accompanied with the appropriate regulatory framework to encourage municipalities to collect their own-source revenues. Rather the expenditure decentralization has maintained the central management of the national budget by the Congress and the President. While state governments have more federal resources to spend, Mexican municipal governments do not. This is creating an increase in legal battles at the national level. Inter-governmental conflict has increased as a result of both Argentina and Mexico efforts to either centralize or decentralize. The next chapter evaluates the local autonomy of the case studies selected and describes the debt capacities of local governments for both Argentina and Mexico. 


\section{CHAPTER V}

\section{INSTITUTIONAL CONTEXT FOR LOCAL GOVERNMENTS IN \\ ARGENTINA AND MEXICO}

\subsection{Introduction}

This chapter compares the legal structures in Argentina and Mexico in order to better understand their level of commitment to fiscal decentralization policies and each country's effort at creating more fiscally autonomous local governments. Argentina and Mexico are two of the four federalist countries in Latin America. ${ }^{25}$ While the decentralization phenomenon has been widespread within the region, not all countries have taken the same process to devolve authority and responsibilities to subnational governments and therefore the process has affected each quite differently.

The chapter tests the hypothesis that the institutional arrangements and legal framework of governments in Argentina and Mexico shape and limit the extent of decentralized policies within each country. The chapter evaluates size, capacity and legal framework of local budgets and how these decentralization reforms have affected the local budgeting. Overall it is found that Argentina's cities officials have more authority to tax, set rates and bases, and make budget decisions than do officials in Mexico. Mexico's local governments are extremely limited and subject to the state's authority for many of their budget decisions.

The last section of this chapter describes the debt capacity for subnational governments in Argentina and Mexico. The chapter tests the argument in the economic literature related to subnational government's debt capacity and need to enforce soft or

\footnotetext{
25 Brazil, because it is a Portuguese speaking country, and Venezuela, because of recent political turmoil, are the other two federalist nations that were not selected for this study.
} 
hard budget constraints, which may create macro-economic instability for their countries. This research shows that Argentine local governments again have more legal authority to take out loans-but they have recently been subject to new restrictions and must have federal treasury approval of these types of loans. Mexico on the other hand has always had a very centralized decision process as regards to obtaining private sector loans regulated by the federal treasury. Even recently as legislation has further tightened, municipalities are increasing their debt loads in Mexico. Wealthier subnational governments often take out more debt, but also have better balance sheets to cover these larger loans.

Chapter $\mathrm{V}$ is broken down into the following sections. First, it provides an overview of the federal structure in both Argentina and Mexico. It describes the tax authority and revenue trends (measured as tax revenues/GDP) at various levels of each of the selected governments. Finally, the chapter concludes by demonstrating the debt capacity of the local governments in this study, thereby showing more accurately the state of fiscal federalism in each country.

\subsection{Structural Comparison}

The creation and unification of the Argentine and the Mexican state were assisted by the use of a federalist system. The term "federalism" is defined as a system of government in which sovereignty is constitutionally divided between a central governing authority and constituent political units (such as states, in the case of Mexico, or provinces in Argentina). Federalism is a system in which the power to govern is shared between national and provincial/state governments, creating what is often called a federation (Watts 2008). 
Table 5.1 provides a review of the institutional frameworks for the four federal countries within Latin America. It gives dates for democratic transitions, year of the Constitution as well as the number and structure of the political units and their ballot structure and timing. Arguably, the administrative division of municipalities is not within the federalist debate. These are often associated with theories of direct democracy and self-government.

\begin{tabular}{|c|c|c|c|c|c|c|c|c|}
\hline \multirow[t]{2}{*}{ Country } & \multirow{2}{*}{$\begin{array}{l}\text { Demo- } \\
\text { cracic } \\
\text { Transi- } \\
\text { tion } \\
\end{array}$} & \multirow{2}{*}{$\begin{array}{l}\text { Most } \\
\text { Recent } \\
\text { Constitu- } \\
\text { tion }\end{array}$} & \multicolumn{2}{|c|}{$\begin{array}{l}\text { SNG Political } \\
\text { Unites }\end{array}$} & \multicolumn{2}{|c|}{$\begin{array}{l}\text { Selection of SNG } \\
\text { Executive }\end{array}$} & \multicolumn{2}{|c|}{$\begin{array}{l}\text { Ballot Structure and } \\
\text { Timing of National and } \\
\text { SNG Elections }\end{array}$} \\
\hline & & & State & Local & State & Local & State & Local \\
\hline Argentina & 1993 & $\begin{array}{l}1853 \\
1994\end{array}$ & $\begin{array}{l}23 \\
\text { Province } \\
1 \text { fed } \\
\text { district }\end{array}$ & $\begin{array}{l}1638 \\
\text { muni }\end{array}$ & $\begin{array}{l}\text { Elected } \\
\text { (1983) }\end{array}$ & $\begin{array}{l}\text { Elected } \\
(1983)\end{array}$ & $\begin{array}{l}\text { Separate } \\
\text { Ballot } \\
\text { Concurrent } \\
\text { Elections }\end{array}$ & $\begin{array}{l}\text { Separate } \\
\text { Ballot } \\
\text { Concurrent } \\
\text { Elections }\end{array}$ \\
\hline Brazil & 1985 & 1988 & $\begin{array}{l}27 \\
\text { States/ } \\
1 \mathrm{fed} \\
\text { district }\end{array}$ & $\begin{array}{l}4974 \\
\text { muni }\end{array}$ & $\begin{array}{l}\text { Elected } \\
(1982)\end{array}$ & $\begin{array}{l}\text { Elected } \\
(1985)\end{array}$ & $\begin{array}{l}\text { Separate } \\
\text { Ballot } \\
\text { noncurrent } \\
\text { Elections }\end{array}$ & $\begin{array}{l}\text { Separate } \\
\text { Ballot } \\
\text { noncurrent } \\
\text { Elections }\end{array}$ \\
\hline Mexico & 1994 & $\begin{array}{l}1857 \\
1917\end{array}$ & $\begin{array}{l}31 \\
\text { States/ } \\
1 \text { fed } \\
\text { district }\end{array}$ & $\begin{array}{l}2412 \\
\text { muni }\end{array}$ & $\begin{array}{l}\text { Elected } \\
\text { (1994) }\end{array}$ & $\begin{array}{l}\text { Elected } \\
\text { Indirectly } \\
\text { (1994) }\end{array}$ & $\begin{array}{l}\text { Separate } \\
\text { Ballot } \\
\text { noncurrent } \\
\text { Elections }\end{array}$ & $\begin{array}{l}\text { Separate } \\
\text { Ballot } \\
\text { noncurrent } \\
\text { Elections }\end{array}$ \\
\hline Venezuela & 1958 & 1999 & $\begin{array}{l}23 \\
\text { States/ } \\
1 \text { fed } \\
\text { district }\end{array}$ & $\begin{array}{l}335 \\
\text { muni } \\
/ 1,084 \\
\text { parish }\end{array}$ & $\begin{array}{l}\text { Elected } \\
\text { (1989) }\end{array}$ & $\begin{array}{l}\text { Elected } \\
\text { (1989) }\end{array}$ & $\begin{array}{l}\text { Separate } \\
\text { Ballot } \\
(1989) \\
\text { Non } \\
\text { concurrent } \\
\text { Elections } \\
\end{array}$ & $\begin{array}{l}\text { Separate } \\
\text { Ballot } \\
(1989) \\
\text { Non } \\
\text { concurrent } \\
\text { Elections } \\
\end{array}$ \\
\hline
\end{tabular}

Overall, the Argentine Federation has a population of 40.4 million and a GDP per capita of U.S. dollars $\$ 6,050 .^{26}$ The federation consists of 23 provinces and one federal district and was established as a unification of provincial caudillos, made up of landowning elite. Argentina has a Presidential system, whereby the President is elected by

\footnotetext{
${ }^{26}$ Notes taken from the CIDE Summer School 2010 lectures on "Federalism and local government decentralization in Argentina and Mexico," taught by Martin Lardone from the Catholic University of Cordoba, Argentina and Mauricio Merino from CIDE, Mexico City, Mexico.
} 
direct vote every four years and can be re-elected only once. The National Congress consists of a Chamber of National Deputies with 257 members and a Senate with 72 members, composed of three senators elected from each province and one from the federal district. The bicameral system has been characterized by malapportionment with an overrepresentation of less populated provinces (Eaton and Dickovick 2004). Often the electoral imbalance creates a challenge for inter-governmental relations because it slants policies toward these provinces and influences the amount of transfers they receive.

The national Constitution makes a distinction of functions by the different levels of government that describe which authorities manage the other levels. The first Article of the Constitution established the federal republican representative form of government in Argentina. Experts have identified that the federal government in Argentina has exclusive responsibility for the following functional items: external relations, issuing currency, regulating commerce and defense. The national and subnational authorities share responsibility for the following functional activities: administration of justice, police, social security, education and health. Table 5.2 presents sections from the Argentine Constitution, which relate to local governments.

\section{Table 5.2 Excerpts from Argentina's National Constitution}

Article 121- The provinces retain all powers not delegated by this Constitution to the federal government, and expressly reserved to themselves by special pacts at the time of its incorporation.

Section 122 - They determine their own local institutions and are governed by them. They elect their governors, legislators and other provincial officers, without intervention by the federal government.

Article 123 - Each province enacts its own Constitution, as provided by Article 5, ensuring municipal autonomy and ruling its scope and content in the institutional, political, administrative, economic and financial. 
Mexico consists of 31 states and one federal district (located within Mexico City's metropolitan area) with a current population of over 113 million people and a GDP per capita of U.S. dollars $\$ 9,715$. Mexico has been heavily influenced by excessive centralization since its revolution from 1910-1920 (Watts 2008). This centralization was further encouraged and driven by the dominant Partido Revolucionario Institucional (PRI) party, which was created in 1929 and held federal executive power until 2000.

Mexico's first Constitution in 1824 defined municipalities as "free;" however, in practice, the nature and functions of local governments was left-up to the states. During the Mexican revolution there were several constitutional assemblies, which finally resulted in the 1917 Constitution, which is still enforced. Authority is divided between executive, legislative, and judicial branches of government, and it established a federal system, which gave significant rights to states in municipalities. Haber et al. (2008) noted that the "Constitution of 1917 contained provisions recognizing both individual political rights (including the freedoms of expression and association) and collective social rights (including rights to land, a minimum wage and free public education)" (Haber, et al. 2008: 118). These authors suggest that the diversification of rights, both to the individual as well as to the collective, have conflicted with one another, which has also effectively put into question who in Mexico is responsible for property rights and local taxation.

Municipalities often enjoyed far-ranging powers, steady sources of income, and internally democratic procedures. According to Selee (2006), "Municipalities were generally responsible for providing education and basic services, administering the law in local disputes, and organizing elections. They also raised revenues through the alcabalas, a form of local tariff on goods passing through a jurisdiction, as well as other taxes and 
fees that they levied" (Selee 2006: 73). The most important part of the Mexican Constitution for local governments is article 115 , which limits state authority and in so doing serves to define municipal governments' responsibilities, authorities, and limits of control. Excerpts related to municipal governments in the Mexican Constitution are in table 5.3.

\section{Table 5.3 Article 115 if the Mexican Constitution}

The States may not in any case:

- Make any alliance, treaty or coalition with another State, or with foreign powers.

- Coin money, issue paper money, stamps, or stamped paper.

- Levy duty on persons or goods passing through their territory.

- Prohibit or levy duty upon, directly or indirectly, the entrance into or exit from their territory of any domestic or foreign goods.

- Tax the circulation of domestic or foreign goods by imposts or duties, the exemption of which is made by local customhouses, requiring inspection or registration of packages or documentation to accompany the goods.

- Enact or maintain in force fiscal laws or provisions that relate to differences in duties or requirements by reason of the origin of domestic or foreign goods, whether this difference is established because of similar production in the locality or because, among such similar production there is a different place or origin.

- Issue bonds of public debt payable in foreign currency or outside the national territory; contract loans directly or indirectly with the Governments of other nations, or contract obligations in favor of foreign companies or individuals, when the bonds or securities are payable to bearer or are transmissible by endorsement.

- States and municipalities may not negotiate loans except for the construction of work intended to directly produce an increase in their revenues.

It was during the Miguel de la Madrid presidency (1982-1988) that there were Constitutional amendments (including Articles 25, 26, and 115) which changed the intergovernmental relationship between levels of government. Municipalities were given unprecedented fiscal and regulatory duties and power. According to Merino (2010), after these reforms took place, federalism in Mexico significantly changed in at least the following ten points:

1. The municipalities were no longer administrative bodies controlled by local authorities. 
2. The municipalities were no longer the preserve of a single party.

3. The councils ceased to depend on resources approved by local legislatures.

4. Local councils run left alone the standards issued by the local legislatures

5. The municipalities were no longer belt transmission of claims and rural conflicts, small villages and scattered settlements.

6. Local executives no longer belong to the same political party.

7. Local executives, meanwhile, were no longer subordinate to the resources and decision of the Presidency of the Republic.

8. Local executives failed to respond to instructions issued by the President of the Republic.

9. A single party no longer dominated the state Congresses.

10. The Congress allowed states to reproduce uncritically the content of the legislation issued by the Congress in their states.

Mexico and Argentina's political, territorial, and organizational structures are summarized in Table 5.4. The administrative structures are relatively similar, with three levels of government, elected democratically. Mexico has more inhabitants, more densely populated, with a higher GDP per capita, but in general organizational terms, the administrative structures are comparable.

\begin{tabular}{|c|c|c|c|c|c|c|c|}
\hline Country & $\begin{array}{l}\text { Levels } \\
\text { of } \\
\text { Gov } \\
(\#)\end{array}$ & $\begin{array}{l}\text { Government } \\
\text { Level Names }\end{array}$ & $\begin{array}{l}\text { Intermediate } \\
\text { Level (\#) / } \\
\text { Average Pop } \\
\text { Level } 2\end{array}$ & $\begin{array}{l}\text { Local Level } \\
(\#) / \\
\text { Average } \\
\text { Pop Level } 3\end{array}$ & $\begin{array}{l}\text { Pop in the } \\
\text { largest city } \\
\text { (\% of urban } \\
\text { pop) }\end{array}$ & $\begin{array}{l}\text { Pop in } \\
\text { urban } \\
\text { agglomerat } \\
\text { ions >1 } \\
\text { million (\% } \\
\text { of total } \\
\text { urban pop) }\end{array}$ & $\begin{array}{l}\text { GDP } \\
\text { per } \\
\text { capita } \\
\text { (current } \\
\text { US\$) }\end{array}$ \\
\hline Argentina & 3 & $\begin{array}{l}\text { Federal, } \\
\text { Provincial, } \\
\text { Municipality/ } \\
\text { Department } \\
\end{array}$ & $\begin{array}{l}24 / \\
1,654,436\end{array}$ & $\begin{array}{l}1638 / \\
24,108\end{array}$ & 35 & 39 & $\$ 6,645$ \\
\hline Mexico & 3 & $\begin{array}{l}\text { National, } \\
\text { State, } \\
\text { Municipality }\end{array}$ & $\begin{array}{l}32 / \\
3,290,016\end{array}$ & $\begin{array}{l}2454 / \\
42,901\end{array}$ & 23 & 34 & $\$ 9,715$ \\
\hline
\end{tabular}

\subsection{Tax Authority and Revenue Bases}

The next section briefly reviews tax collection in Argentina and Mexico. Tax effort is measured as local tax revenues/ total collections (by adding all levels of government). Figure 5.1 shows that total government tax collection is larger for Argentina than 
Mexico. Argentina has a wide difference between total tax collection at the central government, and what is collected at the provincial and municipal levels. Municipal and provincial governments collect substantially more taxes in Argentina than their counterparts in Mexico. Until recently in Mexico, there has been a centralized effort made by the national governments to manage its public finances. This has been done by either changes in the legal authority to raise taxes in Mexico, or by instituting new taxes in Argentina (CIPPEC 2008).

Figure 5.1 Tax Revenues of Argentina and Mexico as percentage of GDP 1990-2009

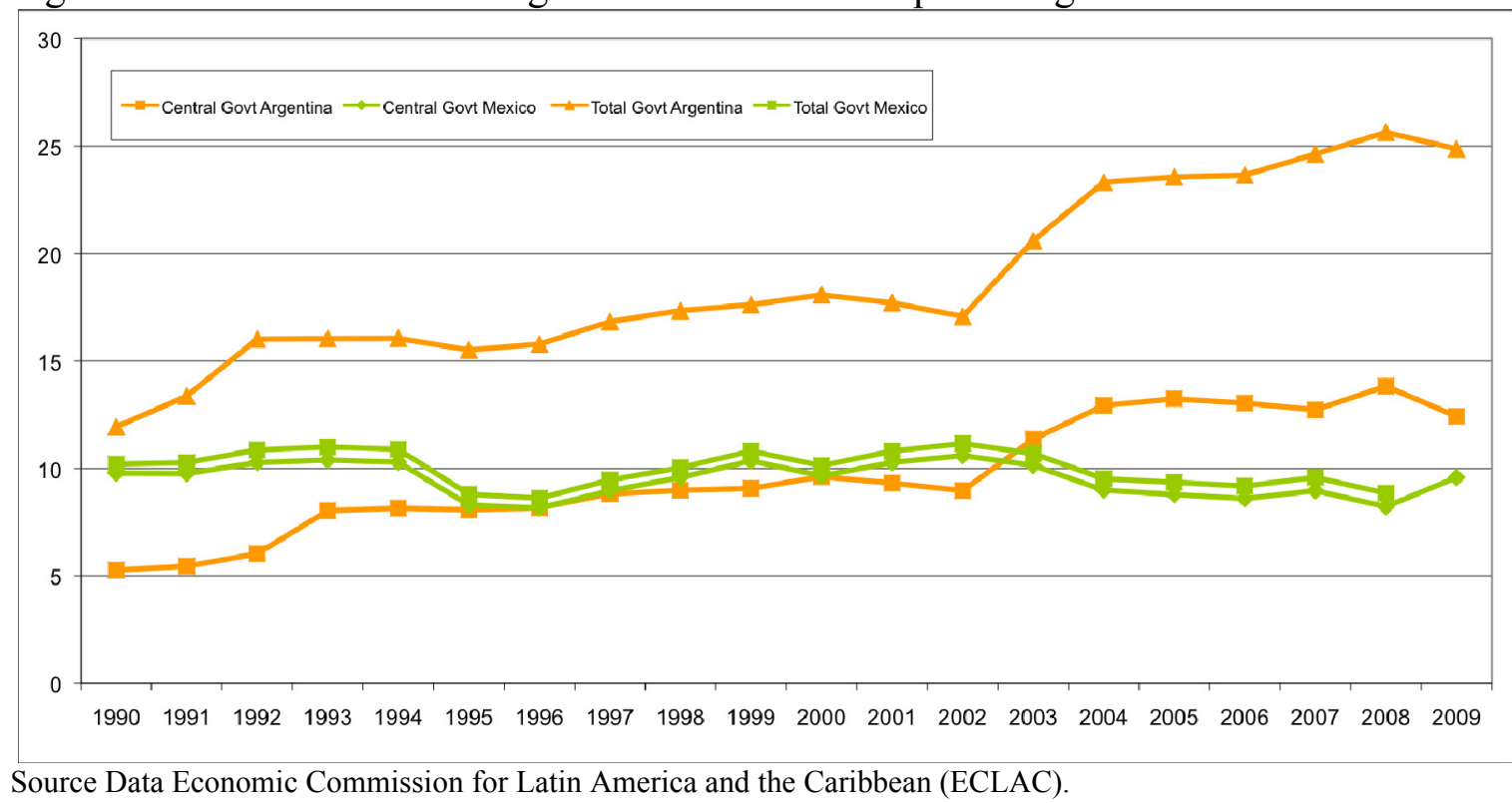

The top orange line in the graph indicates the total government revenues as percentage of GDP; the bottom orange line shows the central governments revenues as a percentage of GDP in Argentina. The wide gap between the two lines indicates that the large difference between what the subnational governments collect and the national government. Mexico, on the other hand represents the middle green lines, which has little variation between the central government and the total government revenues, which indicates that the subnational governments collect relatively little national revenues. The 
historical legacies and institutional frameworks of their federations may have determined these differences between Argentina and Mexico's revenue collection. Argentina has a flexible legal framework that allows local government more authority to collect taxes. An Argentine local government is allowed to introduce new taxes, change its rate and base, while in Mexico, the state governments can dictate these matters. Mexico's central government and states have control to veto local budgets, which further demonstrates that lack of autonomy to administer its budget. There is no consecutive re-election for municipal presidents, which severely hinders the continuation of public policies. The result is that Mexican local governments have less authority and autonomy to collect and manage their local budgets than their Argentine counterparts. Table 5.5 illustrates this reality.

\begin{tabular}{|l|l|l|l|l|l|l|}
\hline Table 5.5 Autonomy Granted in Revenue Assignments to Local Governments \\
\hline Country & $\begin{array}{l}\text { Ability to } \\
\text { introduce } \\
\text { new taxes }\end{array}$ & $\begin{array}{l}\text { Ability to } \\
\text { set tax } \\
\text { rates within } \\
\text { legal limits }\end{array}$ & $\begin{array}{l}\text { Ability to } \\
\text { change tax } \\
\text { base }\end{array}$ & $\begin{array}{l}\text { Control or veto over } \\
\text { local gov't budgets } \\
\text { by Central/Regional } \\
\text { governments }\end{array}$ & $\begin{array}{l}\text { Responsibility for the } \\
\text { collection of }\end{array}$ \\
\cline { 3 - 7 } & Fees & Taxes \\
\hline Mexgentina & Yes & Yes & Yes & No & $\begin{array}{l}\text { Local } \\
\text { gov't }\end{array}$ & $\begin{array}{l}\text { Local } \\
\text { gov't }\end{array}$ \\
\hline Source: UCLG data Collection & No & No & No & Regional & $\begin{array}{l}\text { Local } \\
\text { gov't }\end{array}$ & $\begin{array}{l}\text { Local } \\
\text { gov't }\end{array}$ \\
\hline
\end{tabular}

The types of taxes that local governments can collect are similar. Both governments allow property taxes, fees, and fines to be collected at the local level. The types of fees that each state government collects depend on their individual constitutions. For example, Argentine provinces collect fees for public utilities (such as water and gas) and in Mexico the States determine whether they will collect these fees or not. Table 5.6 outlines the types of taxes and fees collected by each national government. 


\begin{tabular}{|l|l|l|l|}
\hline \multicolumn{3}{|l|}{ Table 5.6 Assignment of Taxes and Fees to Local Governments } \\
\hline Country & Types of Taxes & Types of Fees \\
\cline { 2 - 4 } & Property & Others & Public utilities, fines \\
\hline Argentina & $\begin{array}{l}\text { Urban/rural property (and its } \\
\text { increase value b/c of public } \\
\text { investment* }\end{array}$ & Car registration, turnover tax & Varies by State \\
\hline Mexico & Urban property & $\begin{array}{l}\text { Car registration (all other } \\
\text { taxes are centralized }\end{array}$ & \multicolumn{2}{|l}{} \\
\hline Source: UCLG data Collection \\
* Argentina: Not all provinces have delegated property taxes to their municipalities
\end{tabular}

\subsection{A Description of Subnational Public Debt}

Chapter V closes with a description of each country's subnational debt policies as another way to understand municipal autonomy and fiscal authority. It compares Argentina and Mexico's legislation and recent reforms of sub-national debt financing as a way to better understand each cities' ability to become independent from the national government.

Argentina's Constitution is a unification of the provincial governments. Since the enactment of the 1994 Constitution, there has been a series of financial reforms to increase privatization as well as for the decentralization of administrative reforms. The most recent law of co-participation allows the assignment of transfers and tax revenues to be generated. Each provincial government decides the requirements for its obligations of municipalities. In Argentina, provincial governments are only allowed to tax on specific goods and services as indicated in the state's law.

The independence of the provincial governments makes it difficult to coordinate national programs. Many experts credit the Peronist party's regional leaders (especially when they come from opposite parties such as Santa Fe) for decentralizing policies (Abuelafia, Berensztein, Broun, and Di Gresia 2004; Benton 2009; Bonvecchi 2010). Moreover, governors have an effective role in the balance of responsibilities between 
national and regional governments. The result is a complicated set of rules for each province. For example, the province of Buenos Aries has a set tax rate, which is determined by macro-fiscal measures, pre-determined by the Treasury ministry. The province of Santa Fe may or may not meet the same standards. The city of Buenos Aires has a debt ceiling, which forbids it from taking a loan out that is more than 15 percent of its net current co-participation transfers. Legally, provincial governments cannot take out public debt without the approval of the treasury ministry of the national government.

The province of Santa Fe, for example, has not changed its Constitution since the federal government modified its fiscal rules after the crisis in 2001. The province still has three criteria to categorize their cities - according to its size, its population and its territorial development - to redistribute its public finance to municipalities. Rosario, for example, is one of the most important areas for the economy of Santa Fe, and therefore receives more federal funding than Rafaela. Similarly, the province has not changed its law to better distribute its wealth, so there are other cities that do not have as many resources as Rafaela. Figure 5.3 describes the ratio of public debt that the province has in relationship to the total income (transfers and local own-source revenue).

Figure 5.3 Santa Fe's Public Debt Ratio to Revenue (in thousands of pesos)

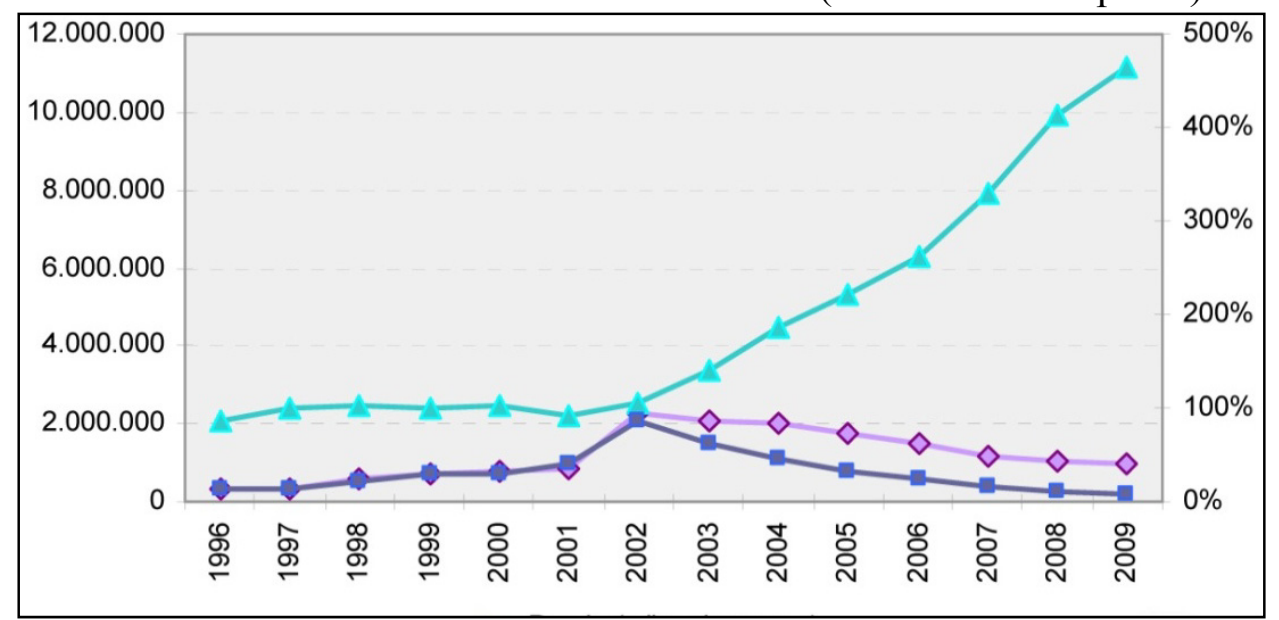

Source: Argentina's Interior Ministry Web site (2011) 
Figure 5.5 illustrates the public debt ratio for the province of Santa Fe. The purple line represents debt (measured in thousands of pesos). The green line is the current revenue (measured in thousands of pesos) and the blue line is the debt/revenue ratio (measured as a percentage). The sharp increase after 2001 is the result of the change in the value of the peso after the reversal of the National Convertibility Law (three pesos equal $1 \$$ US dollar after 2001). The top line is the total percentage of increases in the provincial budget, which also has increased significantly since 2001. The debt for Santa Fe has been managed at a rather low rate, as can been seen in the lowest line in the graph.

Mexico passed Article 9 in the National Fiscal Coordination Law (NFCL) in 1997, granting municipalities the right to contract loans from commercial banks with federal authority. Successfully approved by Congress in 2000, there has been a new emphasis on public debt in Mexico with many subnational governments taking out more public debt. The idea behind this reform was the better use of national bank reserves for development projects. The law requires two rating agencies to evaluate public budgets, evaluating their financial systems, operational activities, financial status, and eight other qualifying criteria (such as economic liquidity, debt, finance, support systems). The four major rating agencies in Mexico include Standard \& Poor's, Moody's, Fitch Ratings and $\mathrm{HR}$, a local rating agency. According to one ratings firm interviewed, of the 2,454 municipalities in Mexico as an estimated 155 have access to commercial banks and 40 municipalities have public debt issued from private banks. 
Figure 5.6 Total Debt compared to a Selection of State Debt in Mexico (2000-2008)

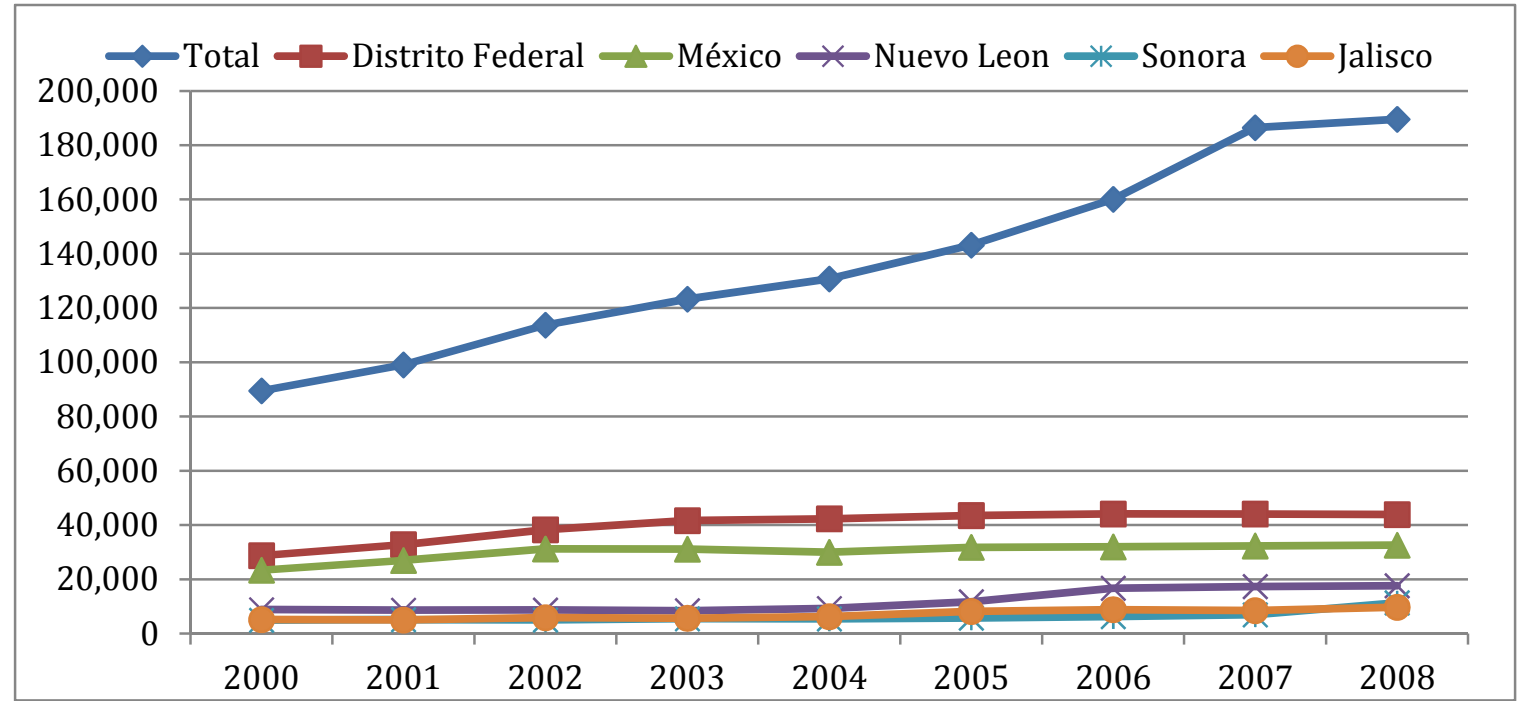

Source: Cámara de Diputados H. Congreso (2008 Mexico) Data measured in Current Pesos

State governments are more likely to take out loans than are local municipalities. According to one ratings agency, loans are used for a wide variety of public services such as removal of groundwater, sanitation, and telephones as well as municipal waste disposal, roads, and traffic lights. Several states, which defaulted on loans during the Tequila crisis in 1994, had the option to restart public borrowing after the laws changed in 2001 (Tamayo-Flores and Hernandez-Trillo 2006). Illustrated in Figure 5.6 are the five states with the highest amount of debt. Nuevo León, Tamaulipas, Morelia, Michoacán are also some of the wealthier states and have recently accessed new loans. They are also among the states that defaulted and were bailed out by the national government in 1994 .

Cities have diverse options for the public loans. City officials can select higher or lower interest rates and longer or shorter terms for the services by using either public or private sector packages. Figure 5.7 illustrates the four categories of loans: development bank (blue line), trust funds loans guaranteed from own-source revenue (red line), trust fund loans with guarantees from the Mexican stock market (green line) and public loans 
guaranteed from future transfers (purple line). Less developed states like Chiapas, Veracruz and Coahuila take out more loans from development bank than from private investors or directly from the capital markets.

Figure 5.7 Types of and amounts of Public Debt of Mexican States (data from 2008)

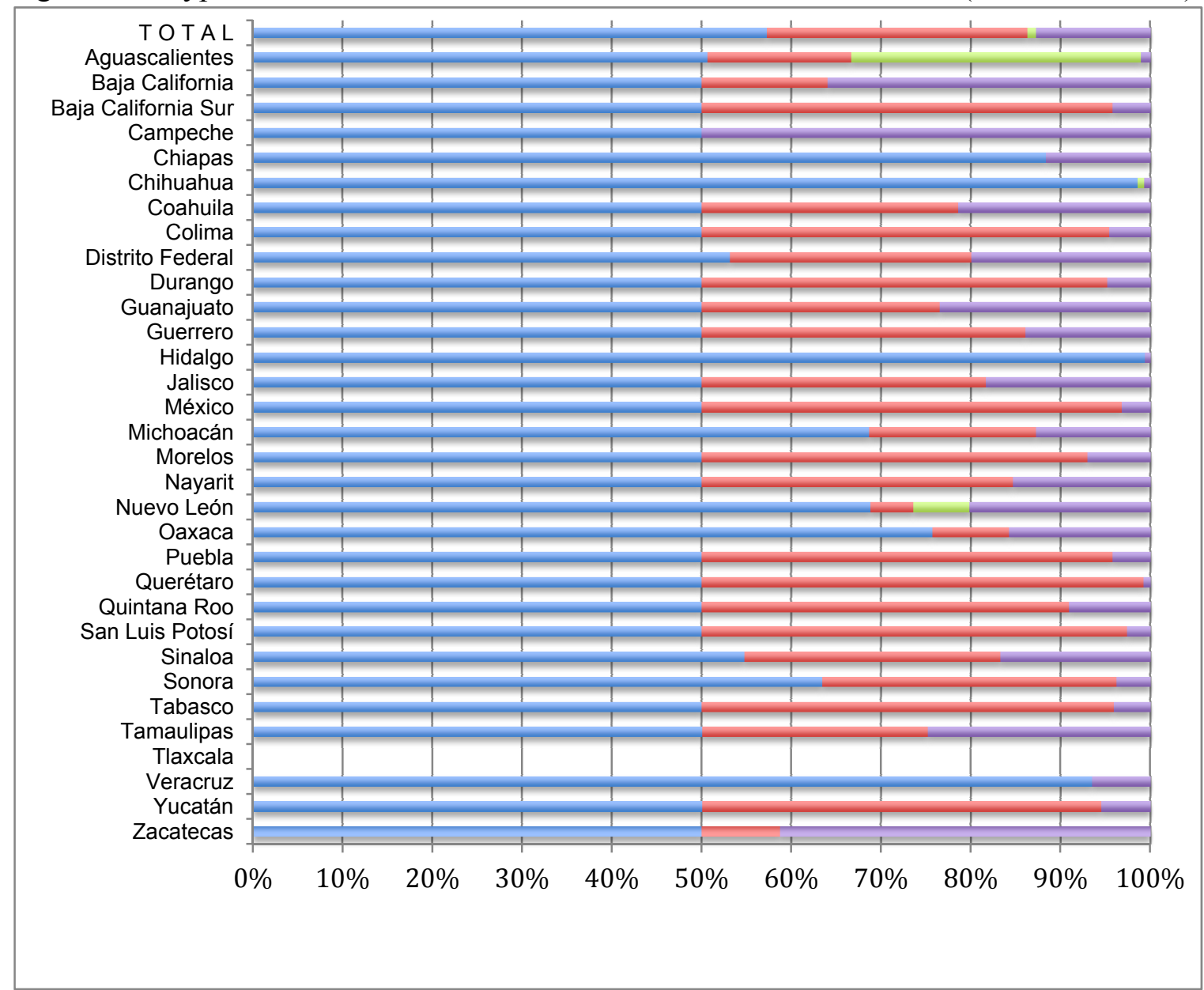

Source: Cámara de Diputados H. Congreso (2008 Mexico) Data measured in Current Pesos

Traditionally, public loans were only allowed to be issued by the National Bank of Public Works and Services (Banobras), the national development bank, which was established in 1933 to finance public works and municipal governments. Banobras managed a loan portfolio of more than $\$ 10$ billion dollars in 2010. The type of loan a state selects is determined by its economic development and the appetite for risk. Banobras uses part of the Federal Reserve to guarantee state government financing. One 
way is by using a trust fund as a financial vehicle, which pays the debtors directly, while leaving a residue in the Federal Reserve. This is important because of the potential influx of foreign exchange, inflation or other macroeconomic factors that devalue the funds in the account. Some states securitize their loans by promising future inter-governmental transfers to pay for these loans.

An alternative financing mechanism is the Bank of North America (NADB) for the Border States, which provides loans for projects that meet United States environmental protection standards. Private commercial loans are also available. Most offer interest rates to short terms, for example, do not allow a rate of maturity of ten years or less. Recently, states like Guanajuato began to manage a World Bank loan program, which allows access to municipal bonds. According to Mexican law, subnational governments cannot borrow without the approval of the national government. This is to protect state sovereignty.

Arguably, municipalities may use the debt to finance public works and other forms of economic development activities, thus allowing the national governments to implement more social programs for poverty reduction. Municipalities need independent audits to evaluate the costs of economic development programs. With the best allocation of resources and increased local taxes, communities can make better decisions about how to use their municipal budgets. This chapter has shown that political parties are less of an important variable for the cities to participate in the bond market, rather the wealthier cities engage in public debt policies first. 


\subsection{Summary Discussion}

The current chapter described how the legal structure of local governments in Argentina and Mexico were created and their effects on to the local taxation system. Because of various fiscal reforms, local governments in both countries are now better able to manage their resources. For example, they can now make complex finance decisions about their budgets. In both countries, municipal bonds can be allocated for infrastructure, but also for managing the budget when extra revenue is needed, such as for paying wages and other expenses. Today, most large international banks provide loans for infrastructure managed at the national level with large amounts of national debt.

It was assumed that with a higher degree of fiscal decentralization, a country would be more likely to have fiscally autonomous states. With a legal review of Argentine and Mexican frameworks, this research suggests that in reality, the history of inter-governmental relations is much more complex. Whereas Mexico has recently seen an increase of fiscal decentralization and a stronger commitment by the national government to decentralize, principally after the 1997 reforms, the country has only decentralized revenue expenditures. Since that time, the appropriate reforms of legal frameworks to create incentives to generate more local revenue have not followed. In Argentina after the economic crisis of 2001, there has been a greater trend of fiscal centralization. Arguably, this fiscal imbalance between the providences is one of the major causes, which led Argentina into macroeconomic instability. After various fiscal major reforms that Argentina made between 1988 and 2008 among other factors has made the country relatively unstable. 
The subsequent chapters examine a set of cities in Argentina and Mexico, in terms of their local fiscal capacity, in order to determine whether further autonomy leads to cities engaging in increased economic development programs and thereby promoting growth. The next chapter specifically looks at Argentina's province of Santa Fe and evaluates how these fiscal reforms have influenced three cities-Rosario, Santa Fe and Rafaela-tax collection efforts and decisions to invest in economic development programs. 


\section{CHAPTER VI}

\section{ARGENTINA'S CASES}

\subsection{Introduction}

Historically Argentina has been more decentralized and now is gradually becoming more fiscally centralized. The purpose of this chapter is to present the three Argentine case studies (the cities of Rosario, Rafaela, and Santa Fe) and describe the demographics, political context, fiscal data, and economic development efforts that each city government has made to influence their local economies. By describing how one subnational government, the province of Santa Fe, managed its public finances, tax structure and investments in businesses, the chapter illustrates the effects of Argentina's centralized tax system. This in turn enables one to better understand how intergovernmental relations have changed.

Although Argentina is a federal country and has decentralized allocation of spending responsibility, it has increasingly created a more centralized tax structure. Approximately 50 percent of total spending occurs at the sub-national level, yet the vertical fiscal imbalance is wide. According to Abuelafia et al. (2004 p22) "in 2003, the federal government collected 81 percent of the total tax revenues, but spent only 53 percent of total expenditures." The authors added that about 5.85 percent GDP is automatically transferred to the sub-national governments through their tax sharing called “co-participaciones” (Abuelafia, Berensztein, Broun, and Di Gresia 2004). Argentina's budget process is already centralized prior to being submitted to the national Congress.

Even as the national government has begun to recentralize its fiscal resources, the research presented in this chapter shows how local governments are managing their local 
budgets and local economic development policies. The evidence in this study shows that fiscal autonomy and economic development are not always correlated. This research also found that local tax collection is not always correlated with implementing economic development programs. Rather each city from the six case studies holds a different view of local economic development and budgeting decisions. The differences may lie within political demands of the party in charge. For example the current socialist government in the city of Rosario does not offer tax abatements to attract businesses, but rather the current administration prefers to provide better social policies in health and education. The more conservative administration in the city of Rafaela has encouraged business development through tax incentives, business incubators, and creating an industrial park. Tax collection efforts of these two cities are more aggressive than in Santa Fe. The evidence shows that tax collection efforts and development programs are not necessarily linked.

Even as Argentina's national tax policies are becoming more centralized, the city governments in this study are rarely effected. Rather efforts to collect taxes and promote economic development programs relate more to politicians own political interest than that of their communities. Finally, the chapter will conclude with a description of three cities within the province of Santa Fe. Each city will have a description of the demographics, political context, fiscal data, and economic development efforts of the city governments and their influences on these local economies. Table 6.1 describes the population, budget sizes and industrial strengthen of the three Argentine cases. 


\begin{tabular}{|l|l|l|l|}
\hline Table 6.1: Case Selection Santa Fe, Argentina \\
\hline City & Size & Population & Budget 2005 \\
\hline Rosario & Large Industrial City & $1,198,528$ & $155,000,000$ \\
\hline Santa Fe (capital) & State Capital & 521,759 & $29,470,000$ \\
\hline Rafaela & Mid-size town & 181,381 & $15,659,000$ \\
\hline \multicolumn{4}{|l|}{ Source: Estimations according to the (National Institute of Statistics and Census (INDEC) 2010) } \\
\hline
\end{tabular}

The next section describes how the province of Santa Fe manages its part of the federal budget and what type of authority that it has to decide budget decisions, such as how much tax revenue the province collects and redistributes back to the national government.

\subsection{The Province of Santa Fe}

The province of Santa Fe (population 3,242,551) has been historically a major industrial base of the country. The province has an active port, lively manufacturing and extensive farming and agriculture production to service its economy. The province currently has an elected socialist government that has been in office for the past two decades. The Partido Progreso Social (PPS) party was created locally to be left-of-thecenter to the politics of the Partido Justicialista (PJ) that Argentina's President Cristina Fernández de Kirchner currently leads. The former governor and mayor of Rosario, Hermes Binner, handpicked the current governor Antonio Bonfatti. Both men represent the Frente Progresista a new formation from the PPS (Agencia Venezolana de Noticias 2011).

The province of Santa Fe has an annual GDP of nearly \$US23 billion dollars and is one of the most prosperous regions in the country. Rosario, the state's major city, contributes more than half of the province's GDP, which is approximately five percent of the country's GDP. Its geographical location, natural environment and port are all factors, which have contributed to the province's economic development. Rosario is the 
province's largest city, with nearly a million residents. The other major city is the provincial capital with the same name, Santa Fe, which has approximately 500,000 people.

\section{The State's Political History}

The province of Santa Fe has developed its socialist political roots from its major industrialized city, Rosario. Although the first nationally recognized socialist politician, Alfredo Lorenzo Palacios was from La Boca in Buenos Aires, the party has strong ties in Santa Fe. ${ }^{27}$ New socialism was developed in 1973 within student groups at the National University of Rosario (UNR) but did not win major provincial elections until the 1980s.

Locally, the socialist began to win elections when Hector Cavallero was elected mayor of Rosario by a stroke of luck. In 1989, Mayor Horacio Usandizaga (1983-1989), representing the UCR, quit in the middle of his second term in office because of a campaign promise that he made. He stated that if Carlos Menem won the presidency, he would resign. ${ }^{28}$ Apparently, a man of hot temper who resented Menem's policies, Usandizaga term was completed by Héctor Cavallero of the Socialist Party (SP).

The national and the state politics, with Rosario leading the way, are vital for understanding the political life for the people in the province of Santa Fe. The current

\footnotetext{
27 Alfredo Lorenzo Palacios (1880-1965) was the first socialist elected to the Argentine Congress, was known as Argentina's father of public administration. Born in Buenos Aires, Palacios studied law at Universidad de Buenos Aires and became a Dean at the University of La Plata. In 1902, he was elected to the Buenos Aires' legislature, and two years later elected to the Argentine Chamber of Deputies to represent La Boca. He helped create several laws including the "Ley Palacios" against sexual exploitation, and others regulating child and woman labor, working hours and Sunday rest. Palacios was elected Senator in 1932, serving until the Senate was dissolved in 1943, and in 1955 was appointed ambassador to Uruguay. In 1960, Palacios was elected again as Senator and as Federal Deputy in 1963. Palacios started a group in the 1930s called "Alto Comercio" which recommended to the country the need for public administration.

28 Usandizaga was first a councilor and then Mayor of Rosario from 1983 -1987 taking the empty seat left behind from Usandizaga. He was re-elected for four more years but resigned and left office on 22 May 1989
} 
provincial governor, Binner's political background started in 1972 when he founded the Partido Socialist Popular (PSP), with fellow student activist Guillermo Estévez Boero from the UNR, a party which later merged with Argentina's Socialist Party (PSA) and other left-wing groups. In 1995, Binner succeeded Cavallero as mayor of Rosario, winning two consecutive terms (1995-2003). Immediately following his campaigned for the governorship, Cavallero was nominated as the PJ candidate. Subsequently after his first defeat, he campaigned once again and reached the governorship of the province with clear majorities in 2007. He beat out the coalition party Frente Amplio Progresista which was made up of JP leaders Rafael Bielsa and Agustín Ross. Binner (2007-2011) was the first Socialist to become the governor of an Argentine province, and the first non-PJ to govern Santa Fe since the return to democracy after the dictatorship.

A medical doctor, Hermes Binner's political strategy has been to focus on social policies for the province. Significant investments have been made to create public health centers. The city decentralized the health center in order to allow more residents to have access to public services. Public health is so important for the province that the Fesprosa, a public coalition of public health employees, campaigned for Binner in his 2011 presidential race. ${ }^{29}$ The province has implemented a large portion of their budget dedicated to public health and social programs. Table 6.1 presents the provinces 19912009 budget expenditures, which include large percentages for education, health, and social services that the state provides.

\footnotetext{
29 The full title of the group is the Consejo Ejecutivo Nacional de la Federación Sindical de Profesionales de la Salud de la República Argentina.
} 
Figure 6.1 The Province of Santa Fe Budget 1991-2009

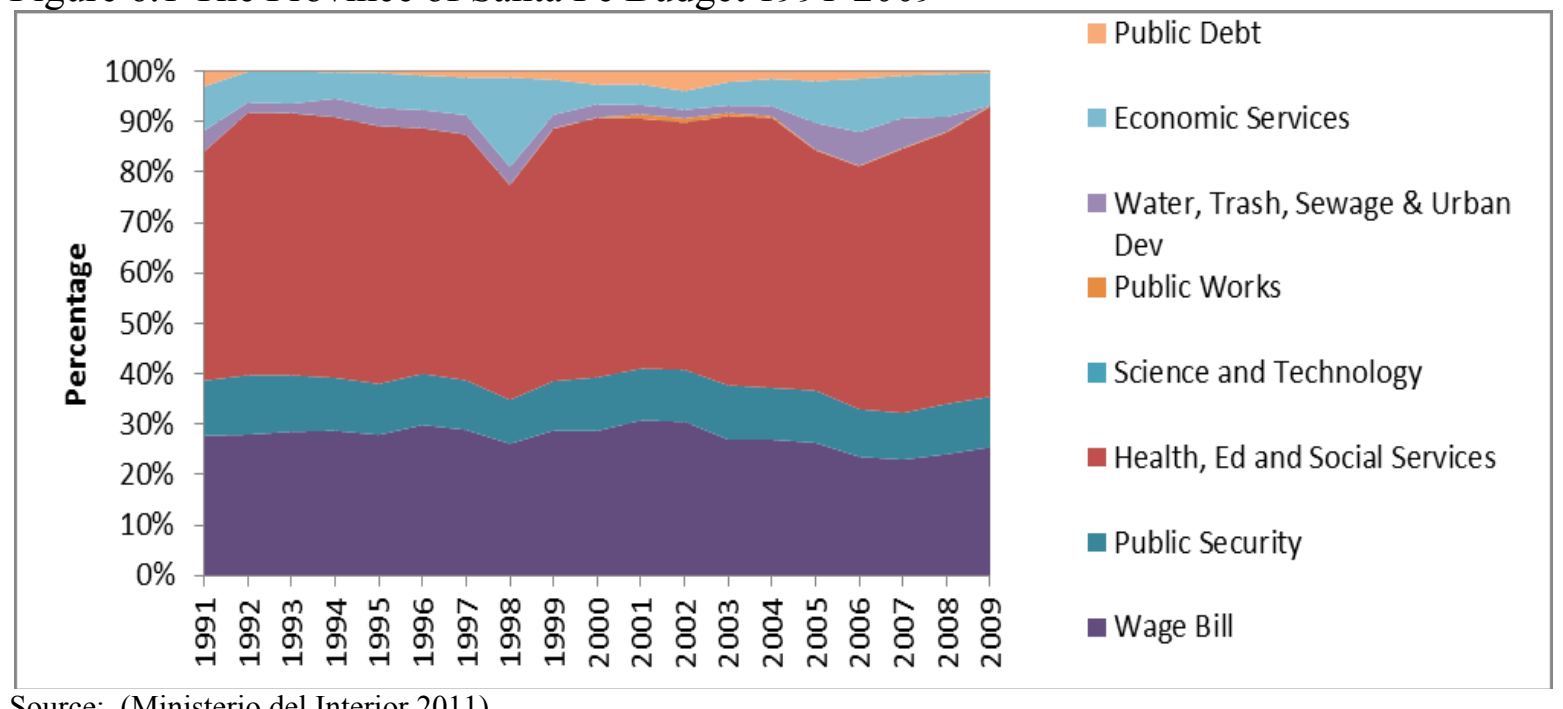

Source: (Ministerio del Interior 2011)

Binner used his social welfare spending to promote a healthy workforce in order to attract economic development to the province. For him, if the government provides good public services then it will attract more international corporations and businesses will relocate to Santa Fe. The socialist government of Santa Fe has capitalized on the decentralized healthcare policies created by former President Menem. An example of this, arguably, was when Governor Binner used his medical background and dedication to social welfare within his political campaigns.

\section{Public Finances}

Argentina's 1994 Constitutional amendment established the institutional structure for municipal transfers. The amendment strengthened the authority of the 24 Argentine provinces to determine revenue streams within their own constitutions within the Federation. Several provinces copied the national framework for the distribution of revenues to local governments. For example, to the province of Santa Fe determined its allocation by charactering its cities into three levels, by population, territorial size and 
poverty rates. The province of Santa Fe also is obliged to collect fiscal revenues in order to share them with the national government. This is the revenue-sharing component of the fiscal pacts described in chapter IV. Because Santa Fe is relatively wealthy compared to the rest of Argentina, it shares a larger portion of their tax revenues.

According to the Liberty Foundation, a conservative think tank in Rosario, Santa Fe's total amount of annual contribution to the national treasury has increased substantially from 2003 to 2009. Although Rosario received nearly four times more funds in 2009, the province is "sharing" more revenues than it received in federal transfers (Leonardi and Mandolesi 2010). The National Fiscal Coordination Office within Argentina's Finance Ministry provided data illustrated in Table 6.2.

Table 6.2 Annual Contributions of Santa Fe to the National Government

\begin{tabular}{|c|c|c|}
\hline Year & Millions of pesos & Annual Variation \\
\hline 2003 & $1,671,940$ & - \\
\hline 2004 & $2,437,410$ & $45,78 \%$ \\
\hline 2005 & $3,000,390$ & $23,10 \%$ \\
\hline 2006 & $3,743,340$ & $24,76 \%$ \\
\hline 2007 & $4,842,110$ & $29,35 \%$ \\
\hline 2008 & $6,175,340$ & $27,53 \%$ \\
\hline 2009 & $6,662,490$ & $7,89 \%$ \\
\hline
\end{tabular}

Source: (Leonardi and Mandolesi 2010:39)

The amount of the national transfers depends on how well a local economy is doing in comparison to other regional areas. The low annual variation observed in 2009 is explained by the contraction of the local economy, which directly impacts the national treasury's budget. Because Santa Fe produces a high amount of agricultural goods, which are shipped around the world, the local economy is based on price of global commodity markets. One report defined this relationship:

If a comparison is made between the funds received by Santa Fe between 20062010, the rate was around 29 percent until June 2008. The rate increased to 40.8 
percent during the first half 2010 [due to the global financial crisis]. This marked an increase of national transfer to the province(Leonardi and Mandolesi 2010:39).

The dependency of Santa Fe on global commodity markets is further explained. If comparing Santa Fe to other economically successful provinces such as Cordoba and Buenos Aires, for the period of 2007-2010. These provinces received approximately to $\$ 20,404$ million pesos, which was 1.98 percent less than what Santa Fe received. Buenos Aires received 2.3 times higher than Santa Fe for a total of $\$ 47,581$ million pesos. The report went on to explain how little the area received in transfers:

If one considers the revenue sharing per capita [funds sent to the federation], the highest amount corresponds to Santa Fe \$2,041 followed closely by Cordoba with $\$ 1,942$ and third place in Buenos Aires with $\$ 993$. Yet when evaluating the federal investments in roads by surface area, Santa Fe shared 49,064 pesos per kilometer, Cordoba 39,573 pesos per kilometer, and Buenos Aries allocated 50,091 pesos per kilometer in 2009 (Leonardi and Mandolesi 2010:40).

It is difficult to recognize the appropriate fiscal balance that the province should collect in revenues and share to the national government. Much of this is highly correlated with international commodity prices. One public official highlighted that with the new farmers' tax (retenciones) established by the federation, created a loss of local revenues for Santa Fe. The new tax on commodity exports increased centralization of finances to the national government because it is now collected by the national government (which is a form of recentralization). When the national government collects the largest share of the local economy, this creates substantial cuts into the provincial budget. The retenciones tax displaced one of Santa Fe's main sources of revenue. Additional research is needed to better understand the fiscal impact of this tax on the transfers for the state's revenue.

Because Argentina is a federation and each province has its own constitution, individually, each sub-national government also decides independently on how to 
reinvest its finances for public works, wage bill and infrastructure development. Within Santa Fe, city governments can collect taxes on urban and rural property, car registration, taxes on propriety property transactions, public utilities, local fines, and fees. Whereby the SNG collects taxes and redistributes only a small percentage to other parts of the government and then to the cities at the various tiers. A majority of these funds are maintained at the city level. Provincial handouts often augment budgets, which can be as high as 50 percent to 75 percent of the local budget. Some of the provincial funds include the funding from the co-participation fund created by the national government and managed by the Finance Ministry. What is clear is that wealthier provinces like that of Santa Fe pay more to the federation than it receives in revenues from the co-participation agreements.

Economic Development and Regional Efforts

In 2008, Binner's team published a strategic plan for the province's economic and regional development. The plan was the result of a deliberative process completed during that same year, in which thousands of residents from the province met to participate in citizen assemblies. The meetings were open to the public so a broad debate could be had to consider future projects and development ideas for the region. Assemblies were held in five separate regions of the province, which the provincial government later used to create new functional territorial divisions for economic cooperation. The "Provincial Strategic Plan" sets up the framework for the priority of programs within five regional levels and is based on three strategic areas: a) Integrated Planning; b) Social Quality, and c) Development Economics (Binner and Bonfatti 2008).

The provincial plan also interconnects the five regional plans into a provincial whole, which further integrates concepts that link education, environment, security, 
health, welfare, water, energy resources and infrastructure development policies together. In terms of economic development, the plan seeks to build better highways, air, rail, waterways, and ports to provide access and transportation options for incoming businesses (Binner and Bonfatti 2008). ${ }^{30}$

One public official admitted that this was the first time in the history of Santa Fe that a strategic plan had been created to link the 362 local governments, which consist of 50 municipalities and 312 small communities. It was indicated that citizens' participation was a first step to becoming more decentralized within the provincial plan. The coparticipation laws provided little help for the province, which collects 60 percent of its tax revenue locally and receives 40 percent from the national fund. Rosario tax collection ratio is closer to ten percent transfers to 90 percent total own-source revenue. This is because of its low percentage of poverty and industrial development.

Santa Fe's provincial budget was approximately US\$5 billion dollars in 2009. For that nearly 66 percent went for salaries for 119,000 employees, the largest percent of the workforce being teachers, police officers and nurses. New investments in infrastructure are only eight percent of the provincial budget. This is compared to social development programs, which are estimated at 40 percent of the budget (much of which are paid in salaries for public health care employees and education professionals). With the federal laws that decentralized schools in 1992 , the provinces paid an additional $\$ 9.9$ million dollars. One public official stated that the national decentralization plan allowed the provincial government not only more responsibility but also justified its costs for public welfare programs. It can be argued that the socialist government has profited politically from the implementation of these decentralized social obligations, for which a majority of its budget is dedicated.

30 The plan was supported by a grant from the European Union in 2008 for approximately US\$1 million dollars to pay for the exercise. 
Likewise, Binner's provincial agenda to decentralize is less about city autonomy and more about a de-concentration of administrative functions. For him autonomy is not financial, primarily because Rosario is the largest city and collects most of the providential taxes. Instead, Binner's fiscal policies have tried to better utilize interjurisdictional relations and set the appropriate taxes and incentives to ensure effective public policies.

It was suggested that the PJ favors a more federalist approach to balance payments across Argentine provinces. The politics of decentralization is often more rhetoric than action within Santa $\mathrm{Fe}$ and across Argentina. In reality, poorer provinces (Salta, Tucumán, and Jujuy) are in worse shape than the more industrialized and wealthier ones, such as Santa Fe, to provide a basic subsidy for Argentina as a whole. Santa Fe is one of Argentina's most affluent provinces and sees its public finances threatened by other subnational governments in the north or south and will fight to maintain more of its local own-source revenues.

According to one public official, municipalities within Santa Fe deliberately do not collect more local taxes because public officials prefer to take advantage of the national transfers. Some municipal officials stated that they have received up to 30 percent transfers (ATNs) from the treasury as unconditional transfers. Although these transfers are not a reliable source of revenue, they do provide help when fiscal gaps appear in rough times. The latter exemplifies the dimensions of Argentine's intergovernmental fiscal balance, which is distorted with poor incentives and its political gaming. 


\subsection{The City of Rosario}

Rosario is known for its progressive government. It has a population of nearly one million people, the third largest city in Argentina. Rosario and its metropolitan district historically has been a major industrial and commercial cluster for Argentina. Rosario is in the southern portion of the province of Santa Fe. The city is situated in a geographically strategic place to work with Mercosur trading partners, located some 300 kilometers from Buenos Aires and on the edge by the Paraná River. ${ }^{31}$ The city is at the heart of an urban agglomeration known as the Greater Metropolitan Area of Rosario, which is highly dense with a rate of about 5,350 residents per kilometer squared and drives much of the economy for Argentina. Over the past ten years, Rosario has been a self-proclaimed socialist government of the people. Governor Binner and Mayor Lifschitz both emerged from the same student movements.

Nearly 71 percent of the population in the Greater Metropolitan area of Rosario was born there; nine percent come from towns within Santa Fe, and 16 percent are from other provinces. The remaining population is foreign born. Approximately 86 percent of households have basic telephone service. Health services are excellent, with 79 percent coverage of primary care health facilities in Rosario. The municipality of Rosario spends more than 25 percent of its budget for health care.

According to one local public official, Rosario's progressive government run by the Socialist party has generated a positive spirit in the public sphere. For example, the city government has organized public conversations through a participatory budgeting system, urban planning forums, public art displays, educational forums and children's art

\footnotetext{
31 Mercosur is a trading block (like NAFTA or the EU) of several countries in Southern America (Argentina, Brazil, Chile, Uruguay and Paraguay are members).
} 
center. The city has extensive public parks, municipal banks among many other public services. Several universities, museums, and cultural centers are located in Rosario. The city has an efficient public transport system and traffic is managed by dedicated bus and taxis lanes. Most buses are powered by natural gas.

Transparency is also a very positive part of the city's image. All the most important laws and bi-annual plan of the city are placed on the Website. Citizens can review the plans for area construction, including infrastructure, parks, in addition to legislation, local restrictions, and permits. In the public plan there is an explanation of public loans that have been contracted to finance infrastructure. In the late 1990s, Rosario invested in a trust to fund municipal projects.

\section{Rosario's Political Landscape}

Rosario's political transformation began in 1989 with Mayor Horacio Usandizaga's resignation. Usandizaga, representing the Unión Cívica Radical (UCR) conservative party, served as mayor of Rosario from 1983-1987. He was reelected for four more years, but resigned and left office on May 22, 1989. After Usandizaga's resignation, the city of Rosario and the state's politics have been controlled by the centerleft. Hector Cavallero of the Progressive Socialist Party (PPS) filled into Usandizaga's seat to become mayor. Cavallero was re-elected from 1991-1995, winning by majority vote.

Cavallero became a transformational figure for Rosario and for the province. Despite his initial socialist affiliation, Cavallero eventually decided to align himself with the Partido Justicialista (or the Peronist party PJ), the party of Carlos Menem and was elected as a provincial deputy from 1999-2003. Even after changing parties, Cavallero 
ran for several other offices, but lost many. Binner proceeded Cavallero as mayor of Rosario from 1995-2003, won a consecutive term from 1995-200 and was later elected governor in 2007.

Cavallero changed parties again to run as mayor of Rosario in 2007 . He founded new party called Social Progress Party (PPS). Even with the support from the governor's candidate Rafael Bielsa and under a new umbrella party called "Frente para la Victoria," which was mostly Peronist (PJ) but had young faces and included the populist sectors of the party (including Omar Perotti from Rafaela). Despite this, Cavallero lost by a landslide to his former socialist collaborator, Miguel Lifschitz (2003-2011).

Interesting social dynamics played a large role in the 2007 mayoral election. Cavallero's campaign tried to reach the wealth socialist elitists from Rosario's urban core, by highlighting the poverty of the people living on the outskirts of town, whom did not benefit from the socialist policies such as new urbanism. Cavallero's 2007 campaign highlighted that sectors of Rosario still did not have water and the city had taken out public debt to establish infrastructure projects, which did not result in public benefits.

Locals complain that politicians seek PJ party leadership when the socialist party does not accept them, although, the PJ also projects a left political agenda. Major contenders of the PJ have links to socialism. For example, Rafael Bielsa (PJ) serves as a federal deputy in the National Congress. ${ }^{32}$

At the time when Binner was elected as governor, he took much of his Rosario staff to Santa Fe, which left the municipality with many new young leaders in charge. Binner handpicked Lifschitz to become mayor and managed much of the municipality's staff that

\footnotetext{
32 Originally from Rosario, Bielsa is the great-grandson of Alfredo Lorenzo Palacios. Bielsa served as President Nestor Kirschner's foreign minister from 2003-2005 and set up National public Law for civil service reform in Argentina while serving as the federal deputy.
} 
remained. Many worked for the gubernatorial campaigns under Binner, and for many this was their first job out of college. The socialist party has been a source for university students to find jobs and conversely to recruit students to help out in local political campaigns.

In 2011, another colleague from the socialist party Mónica Fein was selected to succeed Lifschitz as mayor. In May 2011, she won with full majority (49.6 percent) of the vote over Cavallero (who received 28.2 percent) who ran again, losing for the third time. Fein will resume as the mayor of Rosario in January 2012 (Fein 2011). Since the rise of Cavallero in 1989, the city government in Rosario has experienced several tensions between its various socialists faction, but it is also responsible for producing much of the policy for the entire province.

The city of Rosario is internationally known for its efforts to decentralize the city's administrative offices. During the time when Binner was mayor, he created satellite offices throughout the city where people could apply for birth and death certificates, buildings permits and business applications. Rosario financed the project with a trust fund. The fund was set up as a separate accounting system and was paid by future intergovernmental transfers from the national government. One public official suggested that the city also took the loan from the national treasury, which was administered by the United Nations Development Program (UNDP) program.

At the height of Argentina's hyperinflation in 1989, the city took out a bank credit from the Inter-American Development Bank (IDB), which was for $\$ 65$ million dollars to restructure the operations and the public function of the city in addtion to pay for these satellite offices. The funding paid for the disconcentration of the establishmed and 
administration of the regional offices for the local administration. At the time, Binner was promoting the improvement of health policy, clinics, and services. Binner argued that centers could include health clinics in order to provide care to the residents throughout the city.

According to one public official, the UNDP program offered serve as a guarantor for the loan, locking the interest rates at 21 percent. Although the loan was provided in local currencies (pesos) when the peso was equal to one U.S. dollar. The loan agreement set the rate to be repaid in the total amount, even through the ear of hyperinflation. It lasted through the financial crisis and maintained through that the devaluation of the currency. They payments were reset during the economic crisis and in 2008 there were only $\$ 200$ thousand pesos remaining to pay (approximately US\$70 thousand dollars). The city did not need the provincial government's approval for the loan, but because the laws have changed, it would need it today. One public administrator admitting retold, "the same credit would not be able to be done today, this is mostly because of the set rate for the interest rate and the UNDP as the underwriter."

The city also decentralized its public employees' pension funds from the province through a local settlement. Former President Carlos Menem privatized all pension funds in the 1980s. The city bought out its portion by using nearly 30 percent of the fund and set up a retainer fund for public use. This one action alone created goodwill among the public employees. It required that, the staff must work six months before accessing the fund. Micro-credit funds are available for all city employees. The credits are issued through the Municipal Bank. This helped to radically change the high interest rate loans for entrepreneurs and families to access small credits. 
When Binner first left his position as mayor to take the governorship, he took many of his best staff from Rosario to Santa Fe. Binner and his staff essentially run the municipality directly from Santa $\mathrm{Fe}$, subsequently maintaining many of the original policies he established during his tenure. Binner is known for handpicking his successors and building support with university students. Many students find jobs within the municipality right out of college or after campaigning with the local socialist groups. The public officials are highly efficient, educated, and on the cutting edges of their fields. Many are also highly inexperienced, but very dedicated to learning new ways of providing government services.

Rosario's Municipal Finances

The autonomy of the city to improve its tax collection has been done in the following areas: 1) taxes on property 2) licenses and car registration and 3) business licensing. These credits are meant to increase flows of money in the city of Rosario, and in return, increase economic development. The following section will look at the economy of Rosario and its recent efforts at increase tax collection and budget management. Figure 6.2 has the total amount of Rosario's budget and tax collections at the local level (TOSR). 
Figure 6.2 Rosario Total Expenditures and Revenues vs. TOSR

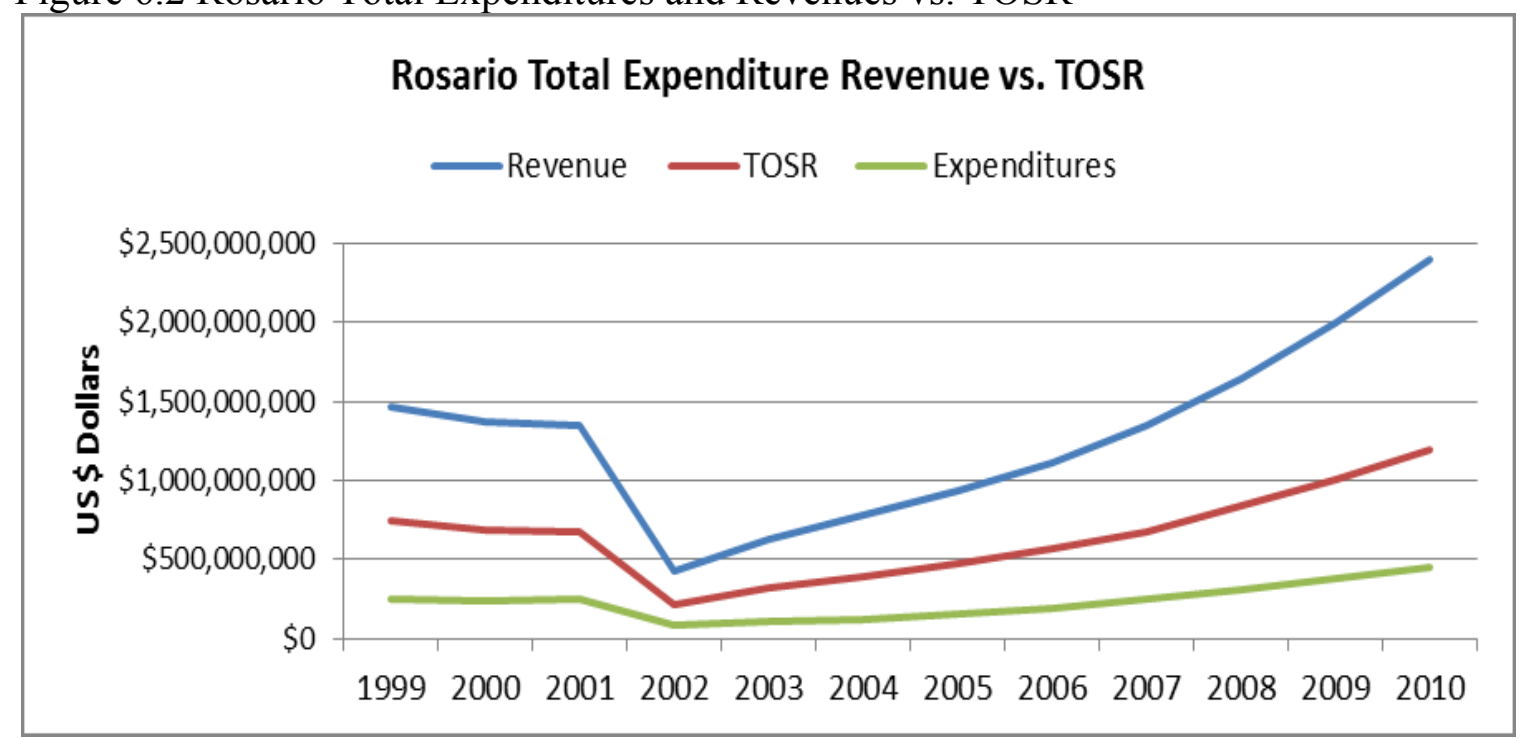

Source: Rosario's Office of the Municipal Treasury 2011.

The city of Rosario has a robust economy and strong internal financial management system. In 2010, Rosario estimated $\$ 2.4$ billion dollars in revenue to be generated with approximately half coming from inter-governmental transfers. ${ }^{33}$ The ratio of own-source collections (TOSR) to federal transfers is approximately 50:50. The total city budget has increased substantially since 2002 . This indicates that the local economy is doing substantially much better since the 2001 financial crisis.

According to Figure 6.3 approximately 40 percent of the budget is spent on goods and services and nearly 20 percent on wage bill (public employment). The city spends less than ten percent annually on its public debt. The ratios for budget expenditures have stayed relatively the same even though the financial crisis in 2001 .

33 Since there is no centralized database by the national government with subnational level or municipal data in Argentina, all city level financial figures for Argentina was collected in person with the municipal treasurer or budget offices. Independent auditing is still not practiced. therefore there is little verification if the financial transactions are correct. 
Figure 6.3 Rosario's Total Desegregated Spending (1999-2010)

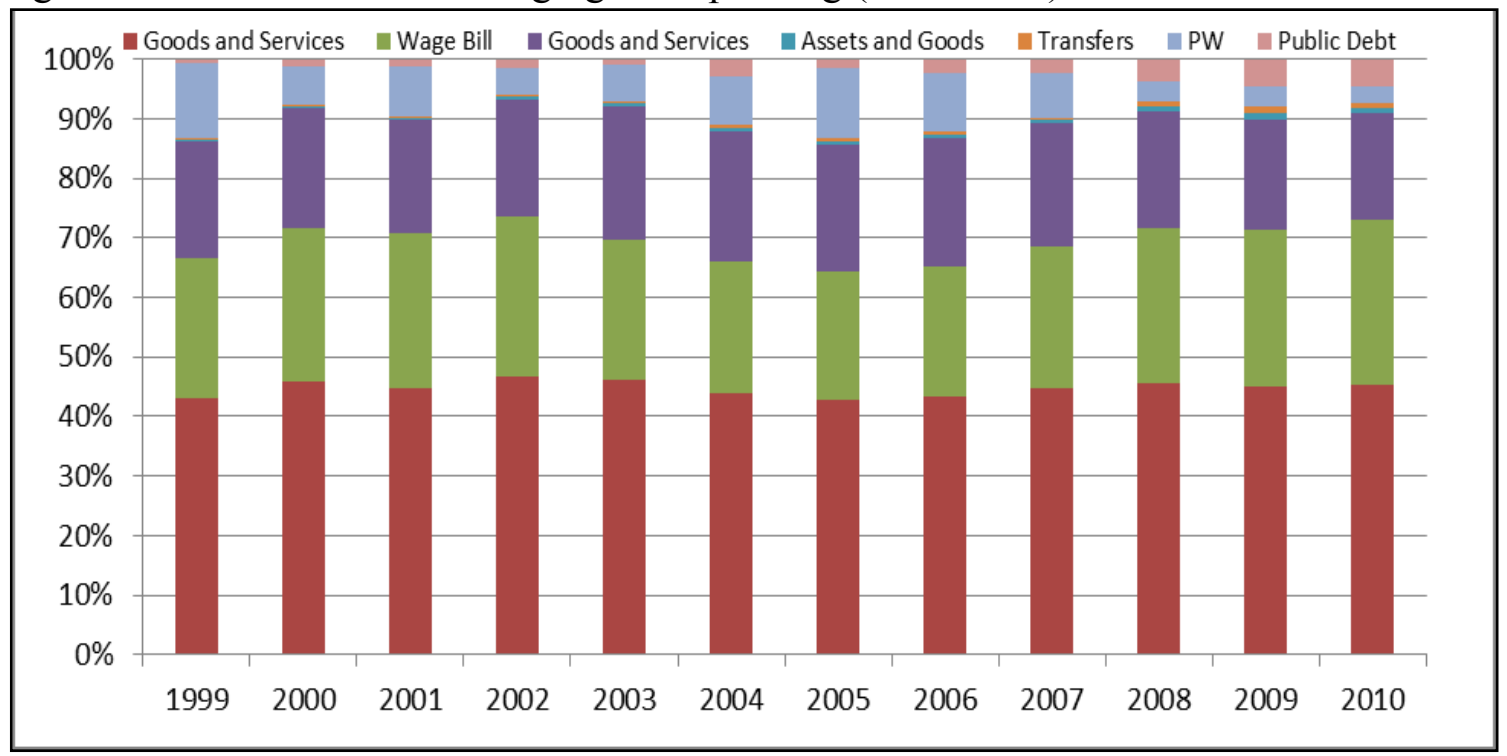

Source: Rosario's Office of the Municipal Treasury 2011

City officials claim that they have used innovative financing to manage the city's budget and promote sustainable revenue streams. The 2010 municipal agenda included its priority focus on: 1) health clinics and facilities with 24 hour care; 2) decentralization of municipal public budgeting, administration, and civic participation; and 3) urban infrastructure development with parks built using public-private partnerships. To build more health centers in 2011, the city had to take out another public loan. To accomplish this, the city's governing body had to request authorization from the federal treasury. ${ }^{34}$

Copied from the City of Curitiba's experience in Brazil, Rosario introduced participatory budgeting (PB) in 2001, at the midst of the financial crisis. However, it was not fully implemented until the 2002 budget cycle. No more than 8-12 percent of the total budget was dedicated to participative budgeting. Arguably, the process was started in Rosario as a political tool to deal with the 2001 financial crisis and public discontentment with the government. PB has now been incorporated into the political landscape of the

34 This is a result of the Federal government's enactment of the 1999 Financial Solvency Act. 
city. Beginning in 2005 , there were approximately 40 assemblies formed and each had different spending priorities and various funding requests.

In general, the process includes the following. Each assembly had a workshop to discuss priorities and neighborhood budgets. Then these groups selected a representative to be a part of the district council. First, the size of the neighborhoods was decided on the percent of population rather than on the percent of people who would be participating in the process. The meetings were open to the public and delegates are selected to be gender neutral (typically representing one woman and one man to the general council). Next the neighborhood groups selected their first plan called "mi barrio," or my neighborhood. The regional delegates meet in a group to analyze the plan and select the top project for each district. Those proposals are further reviewed by the city's budget office for public financing and arrangements are later made within the municipality's public works department to complete the project.

Whether it is the pavement division or the parks and recreation division, the work is completed in the order that it is most efficient to finish. One public official noted that the government had difficulty to disseminate information about completed projects to citizens. For example, the feedback loop of demonstrating to citizens that the work was completed was difficult for the city to manage. The city finally developed a campaign booklet where they published select finished projects.

In 2008 , the total participative budget was $\$ 30$ million pesos and the budget was expected to increase to $\$ 32$ million pesos in 2009 . This means that three percent of the whole budget was used for the program. One bureaucrat explained that the internal administrative office needed to be reformed to manage the participatory budgeting 
process. For example, the public works office had change their structure and timing of project due to the request of cities. They were also responsible to notify the public budgeting office of finished works. Several programming problems have occurred where the public complained of which programs still needed to be done. Similarly, some projects were completed but still not reported to the public budgeting office. Accountability and reporting issues have been problematic. ${ }^{35}$ Unfortunately, in late 2008, the budget was accruing a large fiscal deficit because of the global financial downfall, so the city's program was also in jeopardy.

Another innovative program developed in Rosario, during the financial crisis, was city identification cards for welfare beneficiaries. At that time, the Confederation Organization of Workers (CIT), the union of public employees, signed up all the unemployed people and gave them work. Rosario was the first city to issue private ID cards in order to manage their funds with the work accomplish. The program idea was later replicated by the national government. The cards worked as an ATM or bankcard and allowed people to take out money to buy food. Anyone over 18 could register and more than 50 thousand people began when the program stated. In 2009, there were an estimated 100 thousand beneficiaries of public and social programs in Rosario. This program was replicated by the national government and eventually used in the Plan Jefes y Jefas de Hogar, Kirchner's major social assistance program after the financial crisis.

\footnotetext{
35 For example, the Public Works department takes its time to finish their work and may not have told the office of participative budgeting what they have finished. The Sec. General's office makes the plans for the municipality to set its planning orders. Follow-up is a major issue. With so many problems, one questions whether these projects are just another form of political propaganda (using funds that the municipality already had to maintain public sectors of town) or if there is a value in the participative budget program fro building of democracy, as the liberal theorist suggest?
} 


\section{Rosario's Local Economy}

The Greater Metropolitan Area of Rosario has a vibrant local economy. The area represents an industrial, commercial, and financial center nestled in the heart of the agricultural and livestock producing region. Approximately 42 percent of the economy works in the industrial sector, which consists of 53 percent of total employment. Rosario is emerging as a strategic location which links the state of Rio Grande Do Sul (Brazil) on the Atlantic Ocean with the region of Valparaiso (Chile) on the Pacific Ocean. Greater Rosario is a central place for commerce for many MERCOSUR countries, serving as the crossroads for trade and services. Figure 6.4 describes the industrial base of the region. The data comes from the National University of Rosario UNR (Instituto de Investigaciones Económicas 2011).

Figure 6.4 Sectoral Development of Rosario in US\$ Dollars

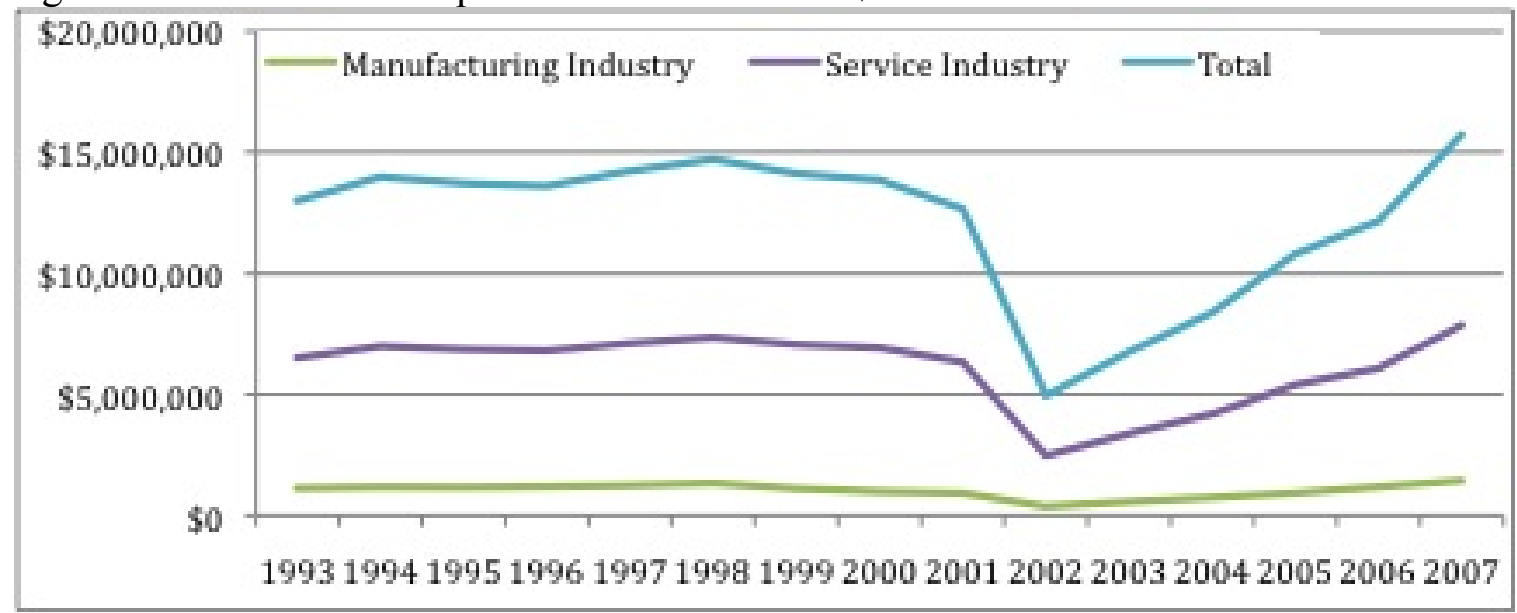

Source: Data from the University of Rosario

A transportation hub for the northern part of Argentina, the city has an extensive network of rail, roads, national highways and provincial inter-connects that link it to other towns within the province and the country. For example, the bus station has daily departures to neighboring countries (Uruguay, Brazil, Paraguay, Chile, Peru, and Bolivia). 
The educational standards are higher in Rosario than the rest of the country. The city has six universities with approximately 77,400 students. The local universities include the National University of Rosario and the National Technological University and Catholic University of Argentina, Austral, the Latin American Educational Center and Abierta Interamericana, which is privately owned. Fifteen percent of the population of Rosario attends or attended the university, which is comparatively higher than the rest of Argentina. Rosario accounts for 60 percent of the provincial researchers, which is eight percent of the national total. This represents a ratio of 18 people in every 10,000 residents that studied science and technology, which is also higher than the national average. It has regional and national science and technology centers.

Table 6.3 depicts the type of employment within the city of Rosario. It provides the type of employment (public, private self employed) at the level of government (municipal, provincial or federal). The region generates 53 percent of employment for the province, where 62 percent of the local industrial establishments within Santa Fe.

Table 6.3 Population according to occupational categories (Rosario)

\begin{tabular}{|llll|}
\hline Category & Municipal & Provincial & Federal \\
Employee in the public sector & $17.81 \%$ & $19.54 \%$ & $21.20 \%$ \\
Employee in the private sector & $49.66 \%$ & $48.22 \%$ & $48.94 \%$ \\
Patrón (local bosses) & $7.46 \%$ & $8.37 \%$ & $6.24 \%$ \\
Self-Employed & $22.10 \%$ & $20.18 \%$ & $20.26 \%$ \\
Family worker & $2.97 \%$ & $3.70 \%$ & $3.37 \%$ \\
\hline
\end{tabular}

Source: National Ministry of the Interior's statistics.

Table 6.4 demonstrates the strength of various sectors to the local economy. Strong industries include trade, manufacturing, electoral, transport and real estate. ${ }^{36}$ In

\footnotetext{
36 The data was calculated by the UNR's economic division former director Alicia Castagna who is married to the Ministry of Economy Angel Sciara for the province.
} 
respect to industry and trade, Rosario is responsible for approximately 50 percent of the total provincial GDP, which is five percent of the national GDP.

\begin{tabular}{|l|l|l|l|l|l|l|l|}
\hline Table 6.4 Economic Development of the Metropolitan Rosario $1993-1998 *$ \\
\hline Sector & $\mathbf{1 9 9 3}$ & $\mathbf{1 9 9 4}$ & $\mathbf{1 9 9 5}$ & $\mathbf{1 9 9 6}$ & $\mathbf{1 9 9 7}$ & $\mathbf{1 9 9 8}$ & $\mathbf{1 9 9 9}$ \\
\hline Manufacturing & 750,009 & 783,783 & 760,639 & 866,785 & 904,595 & $1,048,866$ & 793,718 \\
\hline Electric Gas and Water & 200,512 & 219,473 & 237,171 & 214,348 & 228,582 & 223,475 & 221,234 \\
\hline Construction & 141,828 & 136,345 & 145,934 & 127,757 & 134,864 & 187,455 & 126,731 \\
\hline Commercial sector & $1,323,730$ & $1,401,981$ & $1,163,753$ & $1,280,387$ & $1,436,887$ & $1,611,402$ & $1,485,008$ \\
\hline Hotels and Restaurants & 179,388 & 240,413 & 201,081 & 202,1981 & 222,795 & 199,757 & 205,156 \\
\hline Transport and Communications & 488,090 & 557,413 & 617,356 & 645,847 & 675,690 & 677,883 & 663,311 \\
\hline Financial Transactions & 184,642 & 202,235 & 227,095 & 190,646 & 185,905 & 188,134 & 182,110 \\
\hline Real Estate & $1,443,634$ & $1,551,406$ & $1,501,835$ & $1,529,610$ & $1,575,817$ & $1,611,091$ & $1,569,201$ \\
\hline Public Admin and Defense & 235,863 & 253,502 & 272,186 & 283,889 & 291,259 & 301,082 & 321,561 \\
\hline Teaching & 266,082 & 305,952 & 327,730 & 345,748 & 364,577 & 374,933 & 432,359 \\
\hline & & & & & & \\
\hline Health and Social Services & 312,562 & 369,251 & 443,356 & 433,105 & 420,382 & 472,283 & $5,488,860$ \\
\hline Other Communitarian Activities & 270,401 & 305,126 & 330,839 & 328,034 & 368,401 & 391,125 & 399,058 \\
\hline Private homes & 83,393 & 89,189 & 73,195 & 75,292 & 76,873 & 78,646 & 80,999 \\
\hline TOTAL & $5,880,134$ & $6,416,033$ & $6,302,170$ & $6,523,646$ & $6,886,627$ & $7,376,132$ & $7,029,306$ \\
\hline $\begin{array}{l}\text { Source: (Instituto de Investigaciones Económicas } 2011) \\
\text { *Values are in Millions of Current Pesos (which were equivalent to the US dollars) }\end{array}$ & & & \\
\hline
\end{tabular}

For example, the region of Rosario operates over 3,670 industrial workshops, employing over 63,000 people, which generates approximately US\$1,000 million dollars of added value annually. The main industry of the region is food production (representing 21 percent of industrial activity). As for the food industry, Rosario and its region have the largest vegetable oil complex in the country. This complex accounts for 50 percent of the country's production and 68 percent of which are exported abroad. The port exports products such as petrochemical, paper, lumber, textiles and plastics.

In relation to the metalworking industry, Rosario is one of the regions with the largest agricultural machinery industries for the country with 11 percent of all enterprises within the province. Nearly 17 percent of manufacturing establishments reside in Santa Fe, of which 26 percent are for building machinery and other industrial equipment. This 
item has a long industrial tradition in the city and was particularly from the 1950s and 1970s. Nearly 63 percent of businesses in the area are small and medium enterprises.

Large companies do exist in Rosario. Multinationals, such as General Motors, Dupont, Cargill and John Deere, are located in the surrounding the metropolitan area. The Italian car company Fiat had a plant but left the area after the 2001 economic crisis. The agricultural wealth of Santa Fe helps Rosario's large port complex devoted primarily to international trade in cereals, seeds and oils. Rosario's port complex moves about US\$6,472 million dollars annually in exports and approximately US\$835 million in imports. This area is responsible for 68 percent of exports of vegetable oils in the country, 85 percent of shipments of products and 47 percent of grain shipments. After the 2001 financial crisis, many farmers invested in building and construction, not trusting the banking system, and therefore, many new buildings and shopping centers grew out of the crisis in and are located around Rosario's urban core.

The Rosario Stock Exchange trades futures prices of agricultural commodities such as cereals, alfalfa, and corn. Situated near the port of Rosario, the Stock Exchange manages large accounts that include the pricing of Argentina's industrial and agricultural exports. Rosario's Exchange represents about ten percent of all securities traded in the country, the second most important market in Argentina. The stock exchange operates about $\$ 786$ million dollars in annual revenues, with a turnover rate that excesses over 103,000 local contracts, which is approximately 2.6 million tons of soybeans, wheat, and corn exports. In one interview, the director of international relations highlighted the importance of the stock exchange for the community by identifying that it assists the community with information and economic studies. He highlighted that the exchange 
provides benefits to the local community such as cultural activities with a museum and library. The market also supports a laboratory to test for molecular genetics of the cereals and oilseeds to analyze chemicals for byproducts such as vegetable oils. The physical geography of Rosario provides much of its economic development and serves an important transportation hub for many of the agricultural industries of the country.

\section{Rosario's Economic Development Efforts}

Rosario is the major hub for the province and therefore its economic plan is modeled heavily after the provincial plan. Binner and his staff in the provincial government have used Rosario as a model for the rest of the province while taking advantage of its highly educated workforce, fiscal location and prosperous economic outlook. According to the Provincial Strategic Plan:

The confluence of the main roads of the country and installed capacity in industrialization and manufacturing, together with the ports, make this region a powerhouse. This is an area that favors the development of traditional economies, but also enables a host of opportunities for consolidation of new strategic sectors (Binner and Bonfatti 2008:238).

Rosario accounts for over 70 percent of the production of agricultural machinery in Argentina. Similarly, the auto parts and petrochemical complex, meat, and textile industries, among others are constantly evolving, adding value to markets.

Rosario has internationally recognizable universities and many qualified professionals for research. The National University of Rosario is one of the most prestigious academic institutions in the country, both by the number of students and its level of quality research. Applied knowledge, software development and production, and tourism are some of the new emerging degrees catching the enthusiasm of the region's youth. The major areas of development in the provincial plan include 1) building 
highways, railways, seaport, and airport; 2) improving R\&D centers for innovation; 3) improving the energy production with biofuels and biogas; 4) increasing the number of scientific centers with biotechnology; and 5) finally, improving the of business associations throughout Greater Rosario.

The City of Rosario has set up economic development activities offices throughout the metropolitan region. The city officials use Geographic Information Systems (GIS), to map out businesses, in order to help start-ups (Rosario 2011). City officials indentify establishments and actively seek how to help new businesses by providing public loans and administrative support. For example, the office seeks to strengthen small-scale commercial production by selling local artesian work and linking the value chain of production of products into the same geographical spaces. Finally, the city government also helps to provide training and support for low-skill workers.

In general, the region needs to improve its transportation infrastructure. Currently there is one major highway in and out of the city. An alternative route is necessary to divert heavy traffic, as the major highway often become saturated with grain trucks waiting to load containers to be shipped internationally. Additional public works expenditures are also in bad shape. The city's road equipment is outdated and the city needs to maintain the vehicle fleet to improve the current demand and improve travel times for its citizens. The Paraná riverfront is suitable for small vessels to ship commodities overseas but larger shipments need to be transported through large barges from the Paraná to Buenos Aires (to later be docked and shipped abroad). The waterway needs new technology to make the road and rail access more effective for the port. 
Because Rosario is the epicenter of the metropolitan region, its economy is also based on the service sector and industry. The main economic activities are the city's port logistics, finance, and stock exchange services, the significant presence of SMEs and emerging technology development in the area of biological sciences. The support base of the economy lies in the model of agribusiness and export products derived from this activity. The region accounts for 70 percent of Argentine agricultural exports in the “industrial riverfront," which, combined with the presence of Rosario's Stock Market in the operation of the physical grain market, the futures market and the stock market, is a major strength for the region. The petrochemical, steel, and metal represent a considerable addition, fully integrated into that economy. Clean-energy production and tourism are growing industries in the region. The area also has great scenic spots, which permits deep-sea navigation, fishing, and recreation.

Finally the Provincial Strategic Plan has recognized the region's rich and complex institutions in which the scientific, technological, and cultural plays a leading role for economic development (Binner and Bonfatti 2008). The city seeks to link a network of social actors who work in public and private universities and research centers to serve as information hubs to enhance and the regional economy. By networking the formal and informal sectors and the regional universities, the city of Rosario seeks to provide a strong institutional network to increase social inclusion, facilitate public transit, provide a quality care model, and leverage the bureaucracy to be a decentralized and participatory, to attract the private sector. 


\subsection{Rafaela, Argentina}

Located in the northern part of the province, Rafaela is historically known for fixing trains that stopped on their cross-country journeys from Buenos Aires to the Andes. With its current 83,642 inhabitants, the city has grown rapidly, taking advantage of the railway, which was established in 1890. In the last part of the past century, the residents managed broken trains, which passed through the town. Residents started to manufacture frequently broken parts and since then the locals became experts at manufacturing. When the trains stopped, the city's manufacturing plants began producing auto parts. The area currently has an estimated 400 industrial establishments, many of which are small business owners producing auto parts for export. Rafaela also produces most of the milk and its bi-products such as yogurt, cheese, and butter for the country.

The regional area is known for its high migration from the Piedmont, a region in the northern part of Italy. Population density is less than in Rosario. According to the National Population Census 2001 in the northern region of the province of Santa Fe there is a population density of 2.94 inhabitants per kilometer squared, whereas in the south this indicator is of 22.37 kilometer squared. According to the Provincial strategic plan, the city of Rafaela has the industrial capacity to entice international companies to relocate and develop companies into the area. Many agro-industries are sparsely populated across the region. The city has undertaken a series of initiative to promote local economic development and this growth has been important to the territory to be sustainable.

\section{Rafaela's Political Landscape}

City officials in Rafaela have worked specifically on improving the area's local economic development. The municipality has made a priority for public-private programs 
to promote employment and new venture programs in order to attract additional business development. Rafaela has some political autonomy, but not a large tax base and therefore relies heavily on its regional and national leaders for its public finances, especially for the construction of roads and major infrastructure. Several public officials have noted that the continuity of the same political line between Ricardo Peirone (PJ) and Omar Perotti (PJ) has helped to produce better results in the management of economic resources. Both previous mayors are trained accountants, for which many in the town say they trust an accountant more than a trained politician.

At the age of 31, Omar Perotti (PJ) was elected mayor of Rafaela in 1991. During his first term in office in 1995, his management team earned a presidential award. After a successful term in office, Perotti became the Minister of Production for the Province of Santa Fe. In 1999, Perotti was elected to be provincial senator representing Rafaela in Santa Fe's Congress. In 2002, he lived in Washington DC to complete an IDB training program. After winning the 2003 elections, Perotti returned to public administration to become the mayor for his second term. At that time, his work emphasized the public work for professional development-primarily urban sanitation works and improving the competitiveness of local companies. In 2007, Omar Perotti was re-elected mayor for his third time achieving 50 percent of the vote.

Perotti is currently serving his third term as mayor of Rafaela, but has had several failed attempts at seeking higher office such as a federal deputy and governor for the province. He has been in and out of office of the municipality for over 20 years. For example, when he sought the governorship he formed a coalition party with the Héctor Cavallero as his running mate. At that time, instead he was ran against Carlos Reutemann 
(PJ), a former Formula One racecar driver, transformed into politician and became governor of Santa Fe from 1991-1995. Since the provincial Constitution does not allow for re-election, after four years Reutemann was reelected the governorship from 19992003. During those years, his profile grew to become one of the leading politicians in Argentina. ${ }^{37}$ Ruetemann was preceded and proceed by Jorge Obeid also from the PJ. Still, Perotti an independent Peronist has lead the city of Rafaela into the 21 st century.

When Perotti was not mayor of Rafaela, his colleague from the PJ party Ricardo Peirone served, who had also been a provincial deputy from 2003-2007. Although both men represent the same party, but there have been clashes in their decision-making efforts. For example, Peirone was a direct follower of the former Foreign Minister Rafael Bielsa, both were profound rivals when Perotti and Cavallero sought the gubernatorial candidacy (Castellanos 2006). Nonetheless, the major politician that the city has been exposed to for its recent history is Mayor Omar Perotti and his management team for the past 20 years.

\section{Rafaela's Municipal finances}

Because of the consistency of Mayor Perotti's terms in office, the municipal finances have also been steady and consistent with an operating budget of approximately US\$33 million dollars in 2008. The city collects most of its revenue through taxes on property (i.e. cars, boats, and houses for which includes nearly 40 percent of its total budget), through the registration of industries, and licensing fees. The province considers Rafaela a second tier city (because there are less than one million inhabitants) and

\footnotetext{
37 During the economic recession beginning in 1999 (just prior to the 2001 economic collapse) Reutemann, kept a conservative fiscal policy in Santa Fe, whereby applying discounts and freezing public workers' salaries and pensions through an Economic Emergency Law. The province was among the few not to resort to the issue of government bonds as a form of quasi-currency, and thus did not become highly indebted needing a bail out.
} 
therefore it receives less provincial transfers than Rosario. Property tax rates are established as concentric rings around the city and the size of the terrain, but are not valued on an estimate of the property or the quality of its construction. Whereas the most valuable properties are near the center plaza, the prices of the taxes decrease as the property is constructed outside the outer rings, regardless of its overall size of the property The city does not have a property appraisal office, since the location of the property is what matters more than the quality of the construction.

One public official explained that the Rafaela has had a difficult time with managing its underground water and sewer systems. Several public programs have sought to improve the quality of water within the area and also upgrading the sewage system. To pay for these public works, the city lobbied the national government for support. Especially since the provincial government had divided the territory into five divisions, the city (with its opposition political leadership) is concerned over stalled public works projects. One public official explained that existing projects could not be completed because of the provincial portion of the cooperative agreements was eliminated. According to him, this was "for short-term political gaming over the long term of the benefit of the population."

Another city official suggested that he stays connected with the province by participating in organized forums and meetings. For example, finance officers meet at least once every quarter to review plans and coordinate projects across the province. The municipal treasury explained a federally funded project to improve the highway, which travels from Buenos Aires to Salta, in the northern part of Argentina. A project worth approximately $\$ 50$ million dollars with an annual budget of $\$ 3$ million dollars seeks to 
improve the transportation hub and bring tubes of gas and electricity to the city. For which, in an interview, one public official describe that he was concerned that the provincial government might eliminate a project because the governor and the Federal government did not belong to the same political party.

Figure 6.5 Total Own-source Revenues in Rafaela

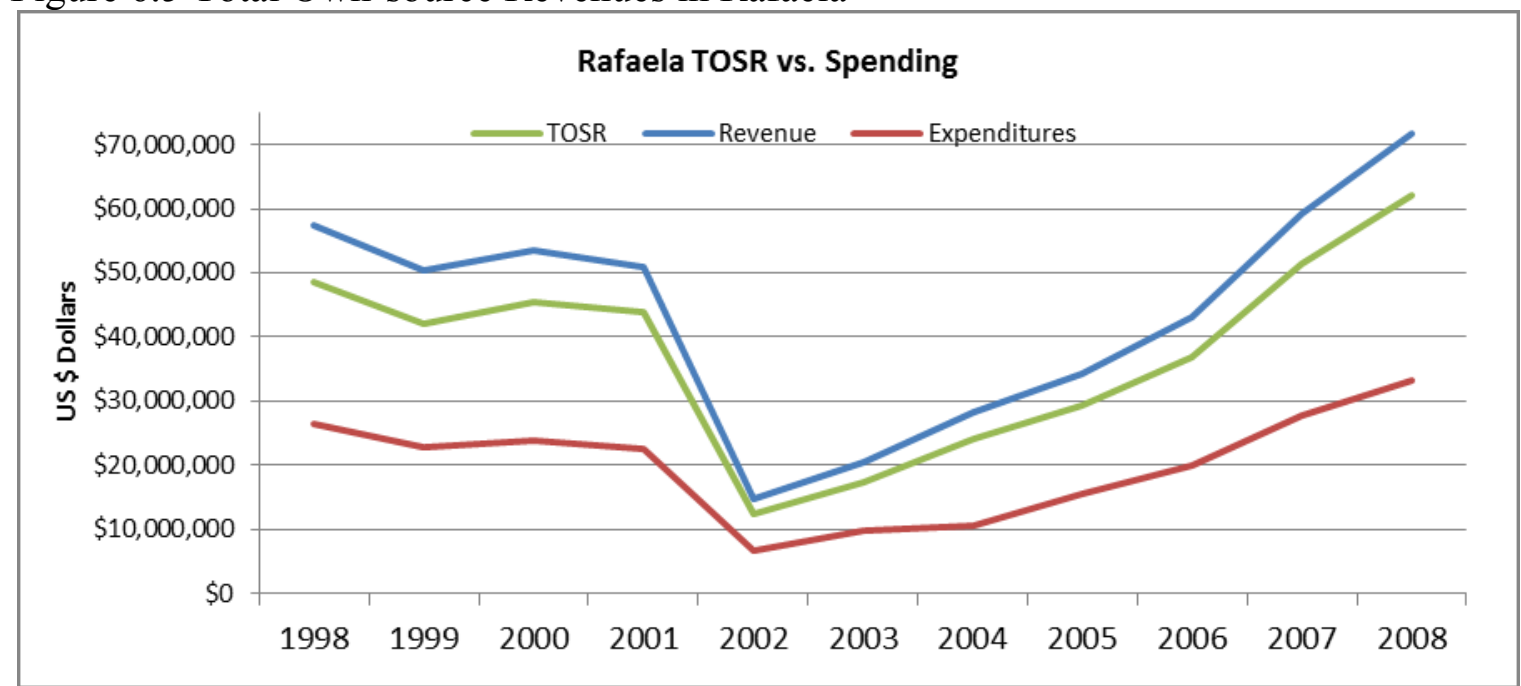

Source: City of Rafaela's Municipal Finances

Figure 6.5 shows Rafaela's tax collection efforts. Its total own source revenues (TOSR) line appears very close to the total collections rate. Yet, with closer look the expenditures line, which should be the same as the revenues, is much lower than the actual budget. This creates an appearance of mismanagement of financial transactions or a data error. The major decline in the numbers after 2001 is due to Argentina's financial crisis, but the numbers have climbed up slowly from that period. 
Figure 6.6 Rafael's Total Spending Disaggregated (1989-2008)

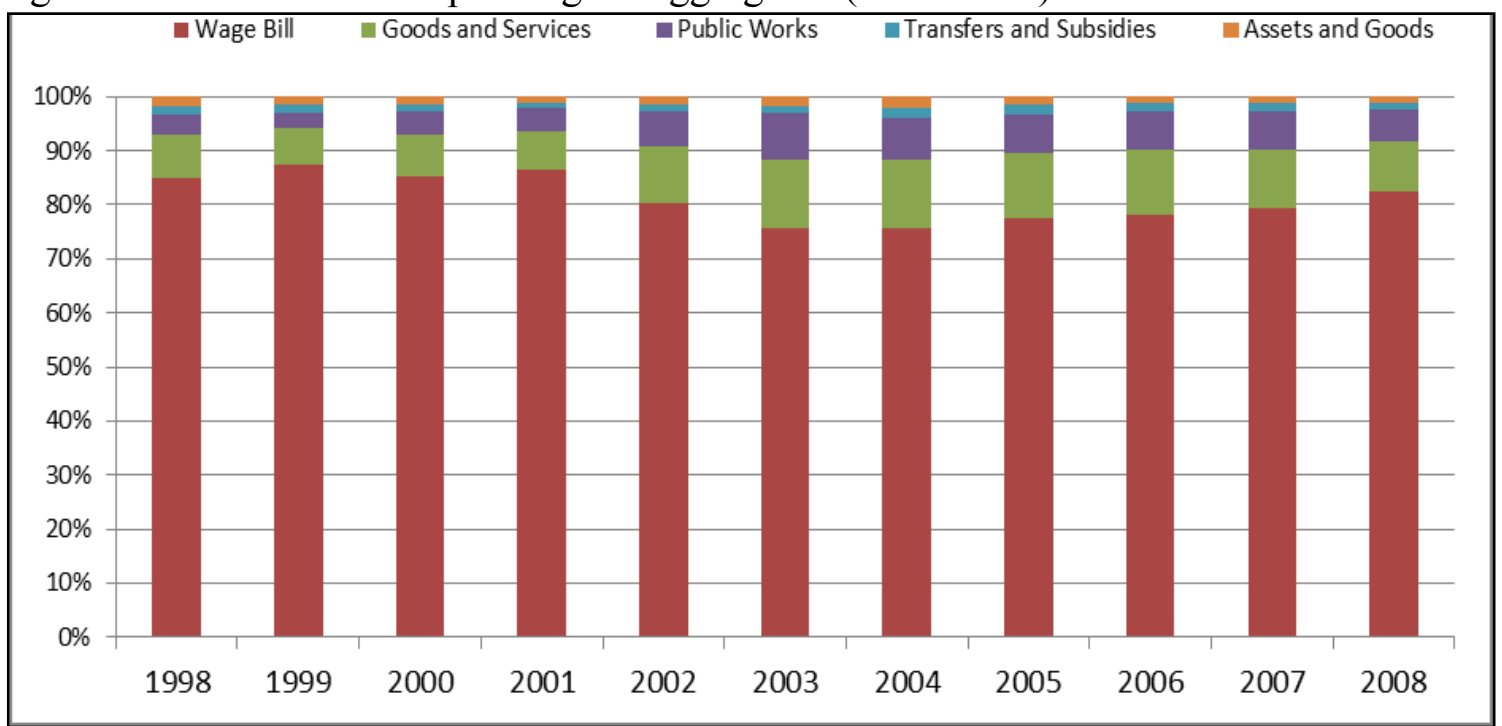

Source: City of Rafaela's Municipal Finances

The budget picture of expenditure showed in Figure 6.6 changes with a majority of the funding for the municipality's wage bill (public employees). This demonstrates that much of the public programs are funded through the higher levels of government and the city itself only funds and manages staff for its programs that it manages. Very little amounts of the city's wealth are dedicated of expenditures such as public works, goods and services or economic development. This reflects the well-qualified public employees working within the municipality. There is also a small line item for international transfers for subsidies, which includes social programs within Rafaela.

Traditionally, municipalities in Argentina were administrative units in charge of garbage, lights, and pavement, and many cities still have the budget category titled it as such Basura, Luz y Pavimento. In Rafaela, the public finance bureau expressed confidence with its level of autonomy, but believed political pressure from representing a different political party (PJ) and the governor's office (socialist) created limited liability of resources for the city. Because the government has been around for many years, 
everyone within the administrative office is friendly, open and honest about the tension between the provincial government and the city administration. City officials manage this relationship delicately.

\section{Rafaela's Local Economy}

Rafaela has a strong entrepreneurial culture and has developed many small and medium enterprises (SMEs). Some locals suggest this culture originates from the high migration from Piedmont region in Italy. Nonetheless of the motivation factor, the region has outstanding results in the quality of the products of the region (Asociación Cultural Piemontesa de Rafaela 2011). According to a publication made by the City of Rafaela:

The industrial power of Rafaela includes 432 companies. During 2005 all the companies in the local industrial unit billed US\$1,936 billion dollars, which include exports of US\$201.9 million dollars. At the end of May 2006, occupied industries 7,798 people in its establishments in the city, 742 in nearby localities and 1,501 in other cities around the country and abroad, bringing to 10,041 the total labor positions that involve firms (City of Rafaela 2007:8).

As can been seen in Table 6.5, a majority of the eligible workers in the municipality are employed by a private sector, many of which are in small and medium enterprises (SMEs). Of Rafael's estimated population of 94,450, a majority are women and nearly 45.7 percent are younger than 30 (City of Rafaela 2008). Nearly 48.8 percent of the population is economically active with approximately 46,200 people working or actively looking for work. The unemployment rate was 5.4 percent in 2008 (City of Rafaela 2008).

Table 6.5 Population according to occupational categories (Rafaela)

\begin{tabular}{|llll|}
\hline Category & Municipal & Provincial & Federal \\
Employee in the public sector & $13.80 \%$ & $19.54 \%$ & $21.20 \%$ \\
Employee in the private sector & $54.97 \%$ & $48.22 \%$ & $48.94 \%$ \\
Patrón (local boss) & $8.21 \%$ & $8.37 \%$ & $6.24 \%$ \\
Self-Employed & $19.93 \%$ & $20.18 \%$ & $20.26 \%$ \\
Family worker & $3.10 \%$ & $3.70 \%$ & $3.37 \%$ \\
\hline
\end{tabular}


The growth of SMEs has increased with a \$2 million dollar grant from the IDB, which funded by a special program that began in 2007 . The city took a participative approach to analyze the economy, its strengths and ways to promote economic growth in 2004 (Oyhanarte 2004). Through this participative approach and guidance by other international development firms, the city decided to strengthen four industrial clusters of metal work, milk production, masonry, and train and car parts. Table 6.6 identifies the major sector of the economy in Rafaela, which has changed little over a five-year period.

Table 6.6 Structure of Rafaela's Economy by Sectors (2004-2008)

\begin{tabular}{|llllll|}
\hline Sector & 2004 & 2005 & 2006 & 2007 & 2008 \\
Agriculture & 2.0 & 3.0 & 1.2 & 1.1 & 1.5 \\
Industry & 25.8 & 24.5 & 24.5 & 27.6 & 23.8 \\
Commerce & 22.2 & 18.0 & 20.8 & 20.1 & 20.5 \\
Services & 43.4 & 47.0 & 44.2 & 43.9 & 46.9 \\
Construction & 6.6 & 6.7 & 9.3 & 7.3 & 7.3 \\
\hline
\end{tabular}

Source: (Municipalidad de Rafaela 2008)

\section{Rafaela's Economic Development Efforts}

The city developed an office for promoting economic development under Perotti's first administration between 1991 and 1997. City officials worked to leverage outside funding to promote the economic base of the community. Part of the project was to develop an industrial park and concentrate business in one area of the city, for which was nearly full when visited in 2009. The office also provided funds for micro-credits for new businesses and supported them through an incubator, which is a central location in which businesses can share functions such as secretarial, auditing, and accounting services. The plan was made official in 2006 with the IDB grant to set up the La Asociación Civil para el Desarrollo y la Innovación Agencia Rafaela (ADICAR) which serves as the secretariat but works between the municipality's office and the business community to promote the local economic strategies (ADICAR 2011). The offices are located in the industrial park 
and claim remarkable success at strengthening the business community in the surrounding area.

Yet, the provincial government has set out different development goals for Rafaela in its strategic plan. The city and province's plans do not necessarily compete but have created conflicts among political actors. For example, several highways need to be maintained and paved. The provincial government sees that the rural road network structure provides great economic activity in the region, mainly that which linked to the dairy industry. But the city officials disagree with the province's strategic plan on which roads need more attention.

The provincial government also identified the benefit of the Piamonte entrepreneurial culture to develop SMEs. The Provincial Strategic Plan features the region with its diversity of products and services that are increasing value and creating employment. It also suggested that the region has a high propensity of outward migration, where young people leave the area to pursue higher levels of education. The provincial government has linked Rafaela's economic plan with the Northern part of the province, but people from Rafaela do not see their economy linked north but rather South to Rosario and Santa Fe. For the province, "the social-economic indicators of this region reveal the diversity of scenarios. While 31 percent of the population of the far North has unmet basic needs, this indicator falls in the south to just over 8 percent" (The National Population Census 2001; Binner and Bonfatti 2008:28).

The socialist government sees weakness in the region's overall infrastructure, which lacks human resources, has difficulties with vulnerable groups (elderly, disabled), 
and persistent problems with illiteracy as well as high school dropout rates. This sort of report is drastically different than the public propaganda that the city produces.

\subsection{Santa Fe, Argentina}

The city of Santa Fe is renowned as the site of various significant moments in the country's political history from the Constitutional Convention in 1853 to the National Constitutional Assembly held in 1994, which produced the many of the last constitutional reforms. ${ }^{38}$ The city of Santa Fe, itself, is home to the three branches of the provincial government. The city also has one of the top provincial universities, Universidad Nacional del Litoral which began its operation in 1919. Overall, the region is also characterized by an active public service, both serving the city and the province. The grain and oilseed production are the city's main industrial activity, which is supplemented by dairy, meat, and leather production. The area also thrives from its livestock sector and timber enterprises. It also has a growing tourist industry. One interview suggested that Santa Fe's economy was built on economic futures and capital gains made from exporting gain through the city's port but there had been no large industrial development as had occurred in Rosario and Rafaela.

According to the Provincial Strategic Plan, the biggest problem for Santa Fe is the high poverty rate, immigration, and at-risk youth. According to the National Population Census 2001, nearly 15 percent of the population lives below the poverty rate. Immigrants come from within the province and from neighboring countries in search of work. Clusters of low-income people have settled within the Greater Santa Fe

\footnotetext{
38 Juan de Garay founded Santa Fe in 1573. In 1660, the Port was declared necessary for the Spanish New World, which caused the boats to circulate in the Paraná River to pay a tax. The city was declared a National Constituent Congress in 1852 and enacted the first Argentine Constitution on May 1, 1853. Constitutional assemblies have also met in Santa Fe in 1860, 1866, 1957, and most recently 1994 to make various important legislative reforms.
} 
metropolitan area and in its surrounding towns. Table 6.7 identifies the type of employment that the working population of the Grater Santa Fe has. Notice that the percentage of self-employed and public sector work is larger than the cities of Rosario and Rafaela.

Table 6.7 Population according to occupational categories (Santa Fe Capital)

\begin{tabular}{|llll|}
\hline Category & Municipal & Provincial & Federal \\
Employee in the public sector & $28.92 \%$ & $19.54 \%$ & $21.20 \%$ \\
Employee in the private sector & $39.73 \%$ & $48.22 \%$ & $48.94 \%$ \\
Patrón (boss) & $6.37 \%$ & $8.37 \%$ & $6.24 \%$ \\
Self-Employed & $22.10 \%$ & $20.18 \%$ & $20.26 \%$ \\
Family worker & $2.89 \%$ & $3.70 \%$ & $3.37 \%$ \\
\hline
\end{tabular}

\section{Santa Fe's Political Landscape}

The current mayor, Mario Barletta (2007-2011), comes from a coalition of Progressive, Civic and Social Fronts, which is a combination of the UCR and PPS of Rosario. Barletta, a professor of engineering from the National University of the Littoral, began his political career as a member of the UCR party. His political discourse is a combination of better social services and fiscal reasonability over the city's budget. For example, one of his first measures in office was to call for an internal auditing of the municipal finances. Barletta also ran for governor but lost in the primaries to Agustin Rossi.

Santa Fe's Municipal Finances

The capital city of Santa Fe has nearly half a million people and one half the budget of neighboring Rafaela with approximately US\$12 million dollars reported in 2008. Santa Fe is ranked a first tier city and receives the same amount of benefits as Rosario. The total budget has fluctuated for the years which data was available. For example, it's all time high of US\$31 million was in 1998 and an all time low of US\$5 
million was in $2004 .{ }^{39}$ These fluctuations can only be understood through a) macroeconomic crisis and its impact; b) local administrative affairs and its mismanagement of funds or c) political relations with the provincial and national governments with increased subsidies. In 2003 there was a devastating flood that affected the outer corridor of the city, for which the public finances were insufficient to help the people left homeless by the flood. At that time, the city government simply relied on the provincial governor for aid. This demonstrates the city's fiscal and political reliance of on the province for funding.

In 2008, the budget bureau attended a national seminar to learn how to manage its finances. Since that time, they use a new budgeting software system, which downloads total revenues, expenditure reports and ongoing expenses into files. Unfortunately, the system does not have a place for past reports and was somewhat difficult and cumbersome to manage the download for the appropriate information requested. The tables listed here do not include these financial reports. Figure 6.7 shows the decline of Santa Fe's revenues and expenditures since the financial crisis in 2001. Also there is a slow recovery of the city's finances since the financial crisis.

\footnotetext{
39 The data was retrieved from the municipality was the only city (from all six case studies) which did not have information in electronic format. Rather instead the budget bureau made photocopies of previously constructed and approved manuals, for which of the data series from 1995-2008, three years were absent from the files. When asked about these years, the administrator suggested that we look and ahead and not behind in the past for guidance.
} 
Figure 6.7 Total Own-source Revenues in Santa Fe

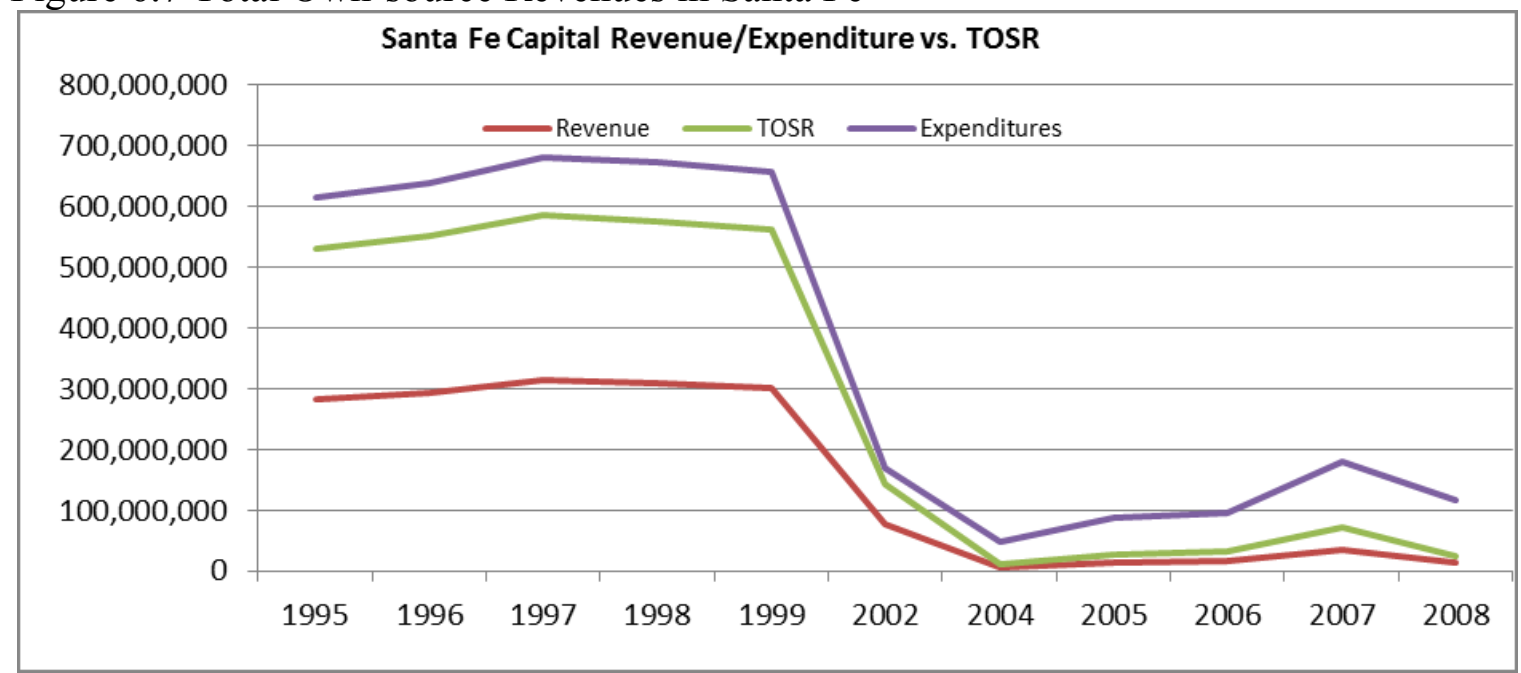

Source: Data is unreliable from municipal records.

Figure 6.8 shows that Santa Fe spends more on wage bill, goods and services and increasingly on transfers than the other cities from Argentina in this study. Additionally, Santa Fe has overdue public debt for which it also is paying. In particular, highly significant is the decrease in their total overall budget overtime, as noted above.

Figure 6.8 Santa Fe's Total Spending Disaggregated (1989-2008)

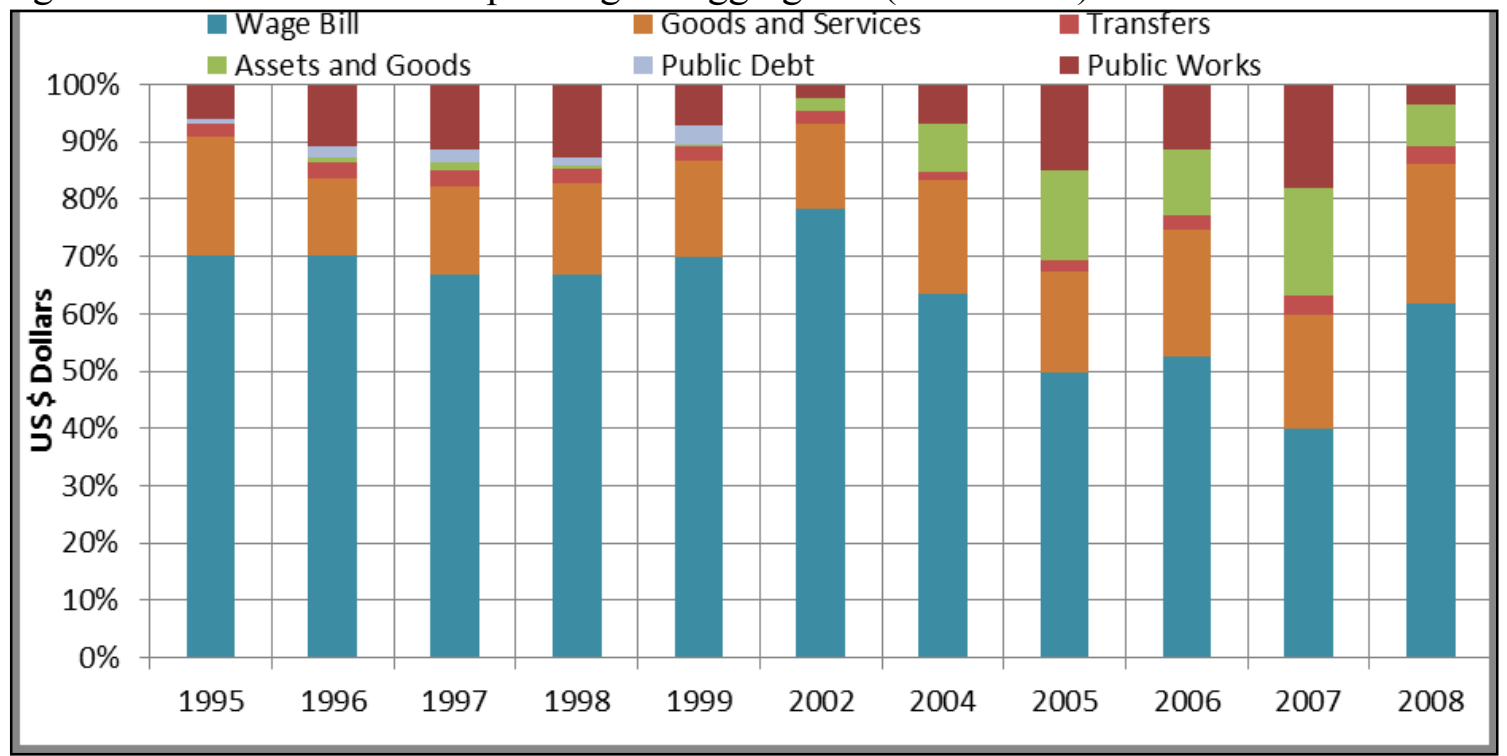

Source: Data from unreliable municipal records.

The city is highly dependent on the province not only for financial assistances but also technical assistance. One city administrator admitted to having shifted positions from 
Minister of Tax Revenue from the province to the city's Budget Direct to return again to work for the provincial government to become the Minister of Economic Development. This further demonstrates the city's high level of dependence on the province for financial, technical and public employees.

Santa Fe's Local Economy

As the capital of Santa Fe, the city is located in a strategic place, both at the provincial and national level with a wide variety economic possibility. The city has little private investment and is still primarily maintained by government activities. Because the city houses many of the capital buildings for the provincial government as well as many of the city's functions, there is little private sector investment. The city has some of the poorest developments in the surrounding areas, which is caused by the immigration of rural farm areas. Major sectors of the economy include agribusinesses, primarily dairy and livestock and their by-products such as meat, yogurt, cheese, and hides. Steel and metallurgy have had great momentum in recent years. Meanwhile, tourism is emerging as a new set of high economic impact for the region. One thriving business includes the local newspaper El Litoral. According to one businessperson, the city incoming investments and finances originate from Buenos Aries. Typically these are investors who seek to speculate in the futures of grain exports and travel to Santa Fe to establish secondary operations.

In terms of regional infrastructure services, Santa Fe serves as the backbone of the providence and provides necessary electricity and natural gas as well as aqueducts and communications services. However, according to the Provincial Strategic Plan, these structural networks fail to supply all the municipalities. The area has a significant 
infrastructure deficit in water, sewer and natural gas. The geographic region has excellent conditions for obtaining drinking water, yet almost 15 percent of households do not have access. While some of the surrounding towns have modern sewage systems, yet only 45 percent of households have coverage. This is a priority for the province to improve the access to sewage and drinking water for all. The same is true for natural gas, where only 46 percent of households in the area have this service.

The city of Santa Fe has several scientific and technological institutions in the area. They include: the Center of Research and Development Regional Santa Fe, the National Water Institute, the National Institute of Limnology, Institute of Technological Development for the Chemical Industry and Technology Park Coastal Center. One major priority for the province of Santa $\mathrm{Fe}$ is to promote synergy between the scientific and productive sectors, and encourage the development of technology parks and industrial areas (Binner and Bonfatti 2008). According to one businessperson, the city expects to have a Hilton Hotel built in the next few years next to the port for business travelers to stay while in Santa Fe.

The growing interest in tourism for the region, in particular of cultural historical heritage, could be an important attraction for many Argentines. The idea is to attract Argentines to learn about the Constitutional reforms and assemblies have meet and create a museum for this type of historical tourism. Currently, tourist services are supplied by private enterprises and therefore the provincial government wants to assist with development of this commercial area (Binner and Bonfatti 2008).

The port of Santa Fe is in the heart of the Parana-Paraguay waterway, which is the last point where overseas vessels can dock on the river. The port of Santa Fe is just 
further north of Rosario and has begun to modernize its infrastructure to meet current cargo demands. The Western shores of the Parana River have fertile soil for small farming. Traditional rice is harvested along the river's islands and marshes. According to the Provincial Strategic Plan, the diversity of climates has created different types of productive activities (Binner and Bonfatti 2008). The area has many small-scale ventures, which cause a poor use of resources for farmers. The small-scale ventures experience structural problems to grow and develop into corporations. The plan suggests that it is necessary to carry out a task of revaluation, incremental improvement, marketing, and management to maximize the utilization of resources, especially in fruit, horticulture, fishing, and small-scale dairy sectors.

Industrial activities in the small towns surround Santa Fe include, such as the Franck dairy center, cattle and slaughterhouse, the Recreation and Nelson, a brewery, the glass industry in San Carlos and tanneries in Esperanza. Also an imminent timber enterprise exists with forestry and fine furniture production beginning, which augments the provision of industrial food systems, traditionally known in the region. The production of cereals and oilseeds are highly pervasiveness, while the commercial and artisanal fisheries, and tourism services are growing.

\section{Santa Fe's Economic Development Efforts}

According to the province of Santa Fe's Strategic Plan, it is necessary to encourage and promote new ventures are ordered to improve the region's economic-productivity (Binner and Bonfatti 2008). Furthermore, the demand for temporary work, mainly to harvest fruit and vegetable, causes an inflow of Bolivia workers, which also have precarious working conditions, inadequate health care and poor employment terms. The 
area has a low-level workforce, in general. Public officials seek to improve educational policy according to its regional economic development.

Finally, the provincial government, through its commitment to develop the area's human resources, has enhanced the access of health care to expand the supply of available personnel. In the surrounding small towns there is a significant deficit of primary health care services. The situation reinforces the centralization and the overload of demands on public hospitals in the city of Santa Fe. Despite the efforts to strengthen human resources, inequity regarding access to health care, the health system appears between different levels of government, which hampers efficiency. The neighborhood structure of the city has flaw too. It suffers from the lack of mobility with medium and high complexity for the transfer of patients, staff, supplies, and drugs. On the other hand, the provincial government recognizes the strength of Santa Fe's science and technology system. Various academic institutions (Universidad Nacional del Litoral, Universidad Tecnológica Nacional, Universidad Católica de Santa Fe), contribute to the formation of highly trained human resources in the region.

\subsection{Summary Discussion}

Many academics describe the Argentine intergovernmental system as highly unproductive, poorly designed and inefficient. Tax compliance is also low both at the national and the provincial level (Abuelafia, Berensztein, Broun, and Di Gresia 2004; Benton 2009; Brown, Díaz Frers, and Koola 2006; Cetrángolo O. and Jiménez 2003; CIPPEC 2008; Dillinger and Webb 1999; Eaton and Dickovick 2004; Haggard and Webb 2004; Leonardi and Mandolesi 2010; Melamud 2010; Montero 2001; Uña 2007). Although tax evasion is hard to calculate, it was estimated that the provinces collect on 
average about 4.5 percent GDP, but there is a considerable variation between provinces (Tommasi, Saiegh, and Sanguinetti 2001).

Argentina's compliance in collecting the value added tax (VAT), for instance, is estimated at 55 percent, which is considerably lower than neighboring countries such as Chile with 80 percent and Uruguay with 70 percent (Tommasi, Saiegh, and Sanguinetti 2001). Recently, several provinces have been bailed out for various reasons, but most economists suggested that this was because the federal government was seeking policies to improve macroeconomic stability, such as decreasing deficits in sub-national budgets or rescuing the ailing pension systems. The national government has had to pay substantial resources for these policy shifts. For example, the deficit was calculated to be approximately $\$ 500$ million in 1996, increasing to nearly $\$ 1.5$ billion in 1998 (Tommasi, Saiegh, and Sanguinetti 2001).

This causes a complicated mess of rules for each city government to understand and comply in order to collect more local revenue. Because the province of Santa Fe has not amended its provincial constitution, they continue to use the same public financing rules, which the nation uses to distribute its funds to municipalities. The province uses three criteria to characterize their cities according to the size of its population, economic, and territorial development. Rosario, has the most important economy of Santa Fe, receives more funds than Rafaela and Santa Fe. Most dependent on its provincial funds is Rafaela because it is not a top tier city. Rather city officials seek political partnerships from the national government, which belongs to the same political party. For example, local administers have relied on the Federal government to support sewage system and improvements on roads around Rafaela. This further demonstrates that the rules of the 
intergovernmental system do not match the needs of local governments to perform their jobs efficiently. Political relations have a direct impact on the success of a city's efforts to promote economic development.

Similarly, the province of Santa Fe has not changed its laws to better distribute wealth. There are cities that do not have as many resources as Rosario, which not only funds the province but also the nation. Because of this, Rosario does collect most of the SNG taxes, which it later distributes to the rest of the province and then to the nation, through the co-participation law. Rosario has been the center of politics for the province since 1989 when the socialist government came to power and took over the city and later, Binner won the governorship. As a result, the government acknowledges that its local taxes help other parts of the country but often has confusing messages about what decentralization means. For the various socialist administrations, decentralization has meant the disconcentration of administrative offices around the city and implementing participatory budgeting.

Finally, Santa Fe has been heavily influence by the provincial government'ts politics and finances. Much of the city official records are inaccurate because of bookkeeping and mismanagement. Because the city is the capital and hosts the provincial government, it is likely that city administrators relied on the transfers from the provincial government to finance public programs over collecting more taxes locally. Little can be concluded about the city's public finances, budget, and tax collection in comparison with the other cases. The next chapter evaluates Mexico's subnational government finances and intergovernmental relations by looking specifically at the state of Guanajuato and three cases Guanajuato, San Miguel de Allende and Leon. 


\section{CHAPTER VII}

\section{MEXICO'S CASES}

\subsection{Introduction}

The purpose of this chapter is to evaluate one of Mexico's state government's efforts at tax collection and its inter-governmental relation. The state of Guanajuato has the sixth largest economy in Mexico with a population of nearly five million people $(4,893,812)$. The state is at the heart of the "Bajio," a region of fertile land, which grows much of the nation's food. At the center of Guanajuato is the village of Dolores, where on September 16, 1810, the priest Miguel Hidalgo led a peasant uprising that began Mexico's independence war from Spain.

Guanajuato is also where former PAN President Vicente Fox (2000-2006) began his political career. The state government has a unicameral legislature and a tradition of being pro-business and conservative. In recent history, Guanajuato has been instrumental in encouraging the democratic reform of the national government. Because of this, Guanajuato is often credited for starting the political decentralization movement in Mexico. Ultimately, the election of Vicente Fox marked the end of the PRI's one-party rule (Tulchin and Selee 2004). The PAN political party has remained in power in Guanajuato and continues this tradition.

The chapter VII is arranged into the following sections. First, it provides a background to the internal politics, natural endowments, and development of the State of Guanajuato's governments, paying particular attention to its recent political and economic history. A similar city-based analysis follows. This section evaluates the public finances, demographics, political, and economic histories of three cities: Guanajuato, San 
Miguel de Allende and Leon as a way to see how these national political efforts are affecting local governments' economic decision-making. A budget analysis of total disaggregated expenditures and TOSR is calculated from 1998 to 2008 for each city. Independent variables of concern are: inter-governmental relations; importance of political parties; and how much the local governments are spending of their own source revenues on economic development programs.

\subsection{The State of Guanajuato, Mexico}

Guanajuato is one of the smallest states in the country. However, it is also one of the most densely populated with $4,893,812$ inhabitants, a density of 152 persons per kilometer squared. The large industrial complexes are the cities of Leon, Irapuato, and Celaya, which comprise of 42 percent of the state's population. In general, Guanajuato's population is very young. The 2005 census reported that 60 percent of the population was less than 30 years old. The state has had a constant increase in population since 1950. Guanajuato has a high rate of emigration to the United States, 35 migrants per 1,000 of the population. The average level of education in the state is 7.2 years, and 50 percent of the population over 15 has not completed primary school. Guanajuato has the highest concentration of Catholics of any Mexican state, with almost 96 percent of the population reported to be Catholic.

\section{Political History}

The political culture of the PAN has been crucial for understanding the economic development of the State of Guanajuato. During President Fox's administration, the PAN politically managed 36 municipalities within the state. Even after the regional elections in 2009 , the PAN held a majority in 27 municipalities, which is nearly 80 percent of the 
state. The PAN state leadership has been strong for many years. The gubernatorial election of 1991 was contested, when the PRI claimed more votes from the PAN. President Salinas recalled the election, placing a defacto governor into office. Two major factors that contribute to Guanajuato's importance to national politics are: first is the traditional Catholic political movement; and, second, is the political aspirations of a former Coca-Cola executive and Harvard graduate, Vicente Fox.

Many people attribute the PAN's fight against the status quo from the states' tradition of Sinarquismo. ${ }^{40}$ This is a political culture that originates with strong proCatholic, hardworking individuals. Many of the "Sinarquistas" political party joined the PAN after the 1964 local election, sharing similar values. Shortly thereafter, the party began to win municipal elections. For the past 20 years, Leon, the largest city in Guanajuato, has been managed by PAN administrations. The PAN's presidential leadership has ended some of the more paternalistic patterns of the PRI (Bailey 1990). ${ }^{41}$

Second, the political aspirations of Vicente Fox have influenced not only the states' politics but also the nation. Fox joined the PAN on March 1, 1988 and ran for the federal Chamber of Deputies, which he won that same year representing the third Federal District of Leon. After serving in the Chamber of Deputies, Fox sought the governorship in 1991, but lost in a contested battle with the PRI's candidate Ramón Aguirre Velázquez. With a close election and possible fraud in the counting of the ballots, results were not immediately published. The race was nationally televised and after one week no one

\footnotetext{
40 The sinarquistas comes from the National Synarchist Union (Unión Nacional Sinarquista) is a Mexican political organization founded in Leon Guanajuato in 1937 as part of the Roman Catholic extreme right, in some ways similar to clerical fascism which, violently opposed to the secularist policies of the PNR, PRM, and PRI governments that ruled Mexico from 1929 to 2000.
}

41 For example, according to one public official, current governor Romeo Hicks did not depend on the national government's political contributions for his state election campaign. 
knew who had won. President Salinas inevitably intervened and appointed an interim governor. For ten days Fox launched a public campaign and mobilized his supporters to request that the official election statistics be publicized. One march included 300 PAN members who walk from Leon to Guanajuato where the State Electoral Tribunal (TEE) in order to demand the election results (Ortiz Pinchetti and Ortiz Pardo 2001). Shortly thereafter, the TEE publicly announced that 30 of the 700 ballot boxes were annulled and Ramón Aguirre Velázquez was announced the winner (Ortiz Pinchetti 2001).

Following the election, intensifying local discontent caused the state Congress to appoint Carlos Medina Plascencia as interim governor, who served until 1995. That same year, Fox decided to run in the following gubernatorial election and was elected governor with nearly 50 percent of the vote. Shortly thereafter, on July 7, 1997, Fox publicly announced that he would run for President (Ortiz Pinchetti 2001). Despite some opposition within his own party, Fox presented his candidacy representing the Alliance for Change, a political coalition formed by the PAN and the Green Ecological Party of Mexico (PVEM). After a complex campaign, Fox was elected to be the President of Mexico with 15,988,545 votes. He defeated the handpicked PRIsta candidate Francisco Labastida who received $13,574,677$ votes or nearly 36.1 percent of the vote, and Cuahtemoc Cardenas, the son of a former president representing the Alliance for Mexico, a left leaning a PRD collation, with 6,259,018 votes (Ortiz Pinchetti 2001). With 42 percent of the vote, Fox become the first candidate, since Francisco Madero in 1910, to beat the PRI.

As governor of Guanajuato, Fox promoted government efficiency and transparency. One public official said that he was the first governor to give a clear and timely account 
of the public finances in Guanajuato. In his time in office, Fox pushed for the consolidation of small firms, promoted the sale of manufactured goods overseas and created a micro-credit industry to support small and midsize enterprise (SME) development. Under Fox, Guanajuato became the fifth most important state in Mexico. Guanajuato received more direct financial transfers while Fox was in office. ${ }^{42}$ Since Fox's term as governor of Guanajuato, the PAN has had majority rule in the state and continues his tradition of open government.

\begin{tabular}{|l|l|l|}
\hline \multicolumn{3}{|l|}{ Table 7.1 Governors of the Guanajuato } \\
\hline $2006-2012$ & Juan Manuel Oliva Ramírez & PAN \\
\hline $2000-2006$ & Juan Carlos Romero Hicks & PAN \\
\hline $1995-2000$ & Ramón Martín Huerta & PAN \\
\hline $1995-1999$ & Vicente Fox Quesada & PAN \\
\hline $1991-1995$ & Carlos Medina Plascencia (interim) & PRI \\
\hline $1985-1991$ & Rafael Corrales Ayala & PRI \\
\hline $1984-1985$ & Agustin Téllez Cruces (interim & PRI \\
\hline $1979-1984$ & Enrique Velasco Ibarra & PRI \\
\hline \multicolumn{2}{|l|}{ Source: Web site for the State } \\
\hline
\end{tabular}

Table 7.1 outlines the governors of the state of Guanajuato. Currently the governor is Juan Manuel Oliva Ramírez, who is also a member of the PAN. Other governors have been influenced directly by Fox. For example, Ramon Martin Huerta was Fox's Security Director prior to becoming governor and later worked as the national Secretary of the Interior. Juan Carlos Romero Hicks served under the Calderon government as the Director General of the Consejo Nacional de Ciencia y Tecnología (CONACyT), a prestigious government agency regulating investments in science and technology research and managing the higher education system in Mexico.

\footnotetext{
42 The INEGI data shows an increase in federal resources was sent to the state during the Fox administration through the various decentralized funds created by Zedillo, particularly through Ramo 33 .
} 


\section{The State's Public Finances}

The state continues to manage its finances and investments as it did during the time when Vicente Fox was governor, noted one public official. The Fox administration did this by creating bureaucratic offices throughout the state for economic development, which were mandated to seek out foreign investments and create financial incentives for companies to relocate to Guanajuato. For example, in 1995 Fox established the Secretary of Planning and Finance, which managed internal finances of the state in order to draw in international investments. In 2000, Governor Romero Hicks established the Secretary for Social Development, and finally in 2003, he separated the two agencies. These miniseries were managed directly by the governor's office. Arrangements were made by changing a law to allow the governor direct control in order to coordinate these special projects.

The State manages the municipal governments through the Secretary of Governance, which also reports directly to the governor. This allows a direct link between the state and subnational leaders such as municipal mayors and treasurers. Each city is requested to send reports to their state government. Reporting standards for the state include financial reports, which are sent to the Public Accounting office (Cuenta Pública) each month and then to the State Congress. Generally the reporting includes income and expense reports. Each state must publish budgetary information by law, even though Guanajuato does not have mandated independent audits. ${ }^{43}$

The state's investment office or COPI, for its Spanish acronym Cooperación de Inversión del Estado, coordinates the state's finances with the regional planning and infrastructure development. The COPI office manages the state's investments and

\footnotetext{
43 The state office of governance reviews its reports (like the US's Government Accounting Office-GAO) to evaluate if work has been completed. The office is often backlogged and does not evaluate each report.
} 
consolidates the public reporting of investments. The office reports to a council for development, which is made-up of public-private partners. One public official listed potential projects, which included ideas such as building university campuses, overhauling water extensions in rural areas and also infrastructure development such as the Celaya highway project, a fast train between Guanajuato to Irapuato, and an internal transportation hub in Leon. Other ongoing projects include new road construction between Irapuato and Leon and highway improvements between San Miguel and Guanajuato.

Although the COPI is small, it manages a large portfolio of investments, which are highly influential for the state's economic development. ${ }^{44}$ For example, the World Bank provided credit of up to $\$ 100$ million in late 2005 for a public loan to the state. However, because of federal regulations, the state was forced to take on the bank credit offered by Banobras, the public investment development bank instead. According to one public official, Banobras had higher interest rates at comparable terms than a private bank. With the loan, the state developed several sectors of the economy (funded water extensions, housing, infrastructure, and provided institutional support to the local governments) and

\footnotetext{
44 The office has 10-12 employees who work full time on fiscal evaluations of the projects as well as project follow-up of the existing portfolio.
} 
also received technical assistance from the bank staff. ${ }^{45}$ Cities within the state have varying credit ratings, which are demonstrated in Table $7.2 .^{46}$

\subsection{Credit Ratings of Guanajuato}

\begin{tabular}{|l|l|l|}
\hline San Miguel de Allende & BBB (mex) & $09 / 05 / 08$ \\
\hline Celaya & AA- (mex) & $22 / 02 / 08$ \\
\hline Irapuato & AA- (mex) & $11 / 06 / 08$ \\
\hline León & Aa3(mex) & $18 / 10 / 07$ \\
\hline \multicolumn{2}{|l|}{ Source: (INAFED Instituto para el Federalismo y el Desarrollo Municipal 2010) }
\end{tabular}

\section{Economic Development and Regional Efforts}

Guanajuato is a major contributor to the Mexican economy. The economy is broken into the manufacturing sector, which represents 26 of the state's GDP; service activities, representing 20 percent; and SMEs, which represents 16.5 percent. The service industry attracted more than two million tourists to the state in 2006 alone (INAFED 2010). Small business sales consist of up 50 percent of the state's GDP and 80 percent of its employment (INAFED 2010). Despite the small share of agriculture in the state's economy, Guanajuato's wheat, strawberries, broccoli, and onions are sold nationally, with their tomato production as the second largest in the country (INAFED 2010).

Guanajuato is highly unequal. In total, only 39 percent of the population is economically active in Guanajuato, (i.e. employed by the formal economy). Marked by high rates of inequality, the region is below the national average. Merely 47 percent of

\footnotetext{
45 The COPI was the coordinating office for the loan, managing the reporting for three years. The office director complained about the paperwork which came with the loan, including the numerous reporting categories and the various requirements for the subcontracting process, especially with public works projects Smith, Heidi Jane M. 2009a. "interveiw with Luis Navarro Rabago, General Director, General Coordinator for Programming and Management of Public Investments, State of Guanajuato." Guanajuato. The development projects and the loan were well known by many public officials throughout the state and the country, as one of the first World Bank sub-national financing projects.
}

${ }^{46}$ Mexico has a BBB country rating for international investors. Than within that grade it has variation between cities. 
the population in Guanajuato receives more than two minimum salaries. Many people do not have adequate housing, basic services, or access to basic medical services. Salaries are also inequitably disbursed among the population, with a large number of the population deprived of decent living conditions.

Although this situation seems grim for the residents, the state paints a different picture for potential investors. The state's economic development office has identified Guanajuato as a place that provides a high quality of life for future employees. The state emphasizes its cultural and traditional values as a selling point for investors (INAFED 2010). Because of generous mineral deposits found beginning as early as the 18th Century, the region is not only the cradle of the Mexico's fight for independence but also has a tradition of creating wealth and having high levels of economic activity. Today the city of Leon dominates the region's economy with high-end tourism and business attractions. The municipalities of Dolores Hidalgo, Guanajuato, and San Miguel de Allende are predominant in tourism with many historical, cultural and other attractions for tourists.

The state's geographic position within the country creates a unique comparative advantage. Attributes include its climate, infrastructure, access to natural areas and cultural centers. For more than 20 years, the auto parts industry has emerged as an important element of economic development. Its robust production of car parts is exported internationally. For example, the state's transportation and manufacture sector is the fourth highest in the country (INAFED 2010). Yet, Guanajuato's local economy confronts many challenges. Several public officials admitted that the state works to attract high skilled labor to move to Guanajuato. For example, the state invests in a first 
class infrastructure to support economic activity. The state also works with the technical schools to develop degree programs.

The capital city of Guanajuato, which holds the same name, has a population of nearly 150,000 inhabitants. Major industrial cities in the state include: Leon with 1,200,000 inhabitants; Irapuato with 520,000; Celaya with 415,000; and Salamanca with 223,000. Each city in Guanajuato has its own history of wealth and development: Leon earned its wealth from the shoe industry; Irapuato for growing strawberries; Celaya for the cultivation of corn, alfalfa, and sorghum, and finally, Salamanca has the state oil refinery, Pemex (Bazan, Estrada, Nieto, Sanchez, and Villanueva 1988).

The government has divided the state into four regional areas1) Leon, 2) Celaya, 3) the San Francisco del Rincón, 4) Purisima del Rincón, which is located in the Western part of the state bordering Jalisco. ${ }^{47}$ For each area the state has assigned federal transfers (Ramo 33) for urban development. Currently, the state's priority is to develop these metropolitan zones. It has created specialized trust funds for economic development, which include infrastructure development areas. ${ }^{48}$

Each of these regional areas have development councils, which are called Consejo de Planeación para el Desarrollo del Estado de Guanajuato (COPLADEG)—organized through the state's planning council called the Instituto de Planeación Estatal (IMPLAN). According to one public official, these councils only work some of the time.

\footnotetext{
${ }^{47}$ In dealing with municipalities, the state has a specific office to manage municipalities, which is located within the Secretary of Governance, and offers training programs for local government officials. The office also monitors and evaluates each municipality and provides technical assistances for local government officials with issues, problems and high amounts of citizen complaints. Essentially, this office helps manage the municipal authorities. The municipal law mandates that each municipality have 12 to 15 locally elected commissioners.

48 National agreements were created in 2007 and 2008. Both were formally named with funding allocations and business plans to match.
} 
For example in Leon, the planning committee is active and consists of many members of the business community. Yet, the committee has had to change its strategy several times because of citizen protests from the northern corridors to the east and the west. The municipalities of Leon, Celaya, Irapuato, Romita (which is a smaller town located between Guanajuato and Leon) are part of the industrial corridor that maintains the state's industrial activities.

Some citizens have criticized the state's economic development policies. ${ }^{49}$ Traditionally, the PAN leadership sought to bring new firms into the state by attracting multinational corporations and offering tax breaks and low-wage workers. This economic model has been successful to bring many firms into the state. The American car firm General Motors (GM) moved into Celaya in 1990, which effectively changed the economic matrix of the state. Shortly, thereafter the city of Celaya developed an industrial park near a major highway, which serves as the major artery for the Bajío. This highway serves to transport agricultural, industrial products and people to and from the major regional airport. One economic development director retold that when the GM plant was installed, the foreign management promised to produce the 3,500 jobs, but instead produced fewer low-skilled ones. The director continued, "At the time when the plant was opened, the citizens who worked there couldn't even afford the car they made nor were they offered financial plans to obtain one."

\footnotetext{
${ }^{49}$ Dr. Suarez Paniagua, Director of Social Sciences and Humanities, University of Guanajuato, Leon Campus, takes a sociological look at the developmental process of the state and analyzed the implications of the GM plant and its implications for women workers. In an academic presentation at LASA in Rio de Janiero (June 2009), she described the life/work balance for people within the state and their relationships with the current government's efforts at economic development.
} 
The next section of the chapter describes the three case cities in Guanajuato. First it looks at Guanajuato (capital), then San Miguel de Allende, and finally, Leon. Each has a different economic base and approach to its municipal finances. For example, Guanajuato (capital) may be considered to be one of the most fiscally autonomous and independent cities in the Mexican Federation. The city recently annexed the Museo de Los Momias (Mummy Museum) which was part of the national patrimony from the country and is a source of great pride to the community. In order to accumulate more local revenue, the city now charges entrance fees, which produces more revenues than property tax, rents, and fines combined. This translates into a double income to invest in public works to strengthen the tourism sector of their economy. San Miguel de Allende is an ancient city in the Cordillera del Bajío, which has about 140,000 inhabitants, 20 percent of them are retired Americans who do not speak Spanish. The city depends largely on this foreign influence for economic development. Finally, Leon earned its wealth from the shoe industry and now has several new industrial developments. For each case, a short description will be provided depicting their political histories, public finance records, and economic development. Finally, the chapter describes each city's initiatives to further spur economic growth. Table 7.3 sets data from each of the cities' population, GDP, average per capita salary and total budget revenues.

\begin{tabular}{|l|l|l|l|l|}
\hline Table 7.3 Mexican Case Demographics \\
\hline City & $\begin{array}{l}\text { Population in } \\
\mathbf{2 0 1 0}\end{array}$ & $\mathbf{2 0 0 5}$ GDP & $\begin{array}{l}\text { 2005 GDP } \\
\text { Per capita }\end{array}$ & $\begin{array}{l}\text { 2005 Budget } \\
\text { Revenues }\end{array}$ \\
\hline San Miguel de Allende & 160,383 & $1,065,245,712$ & 7,647 & $30,000,000$ \\
\hline Guanajuato & 171,709 & $1,493,480,230$ & 9,738 & $24,000,000$ \\
\hline León & $1,436,480$ & $16,191,394,636$ & 12,668 & $180,000,000$ \\
\hline All financial information is in US dollars Source: Mexico's CONAPO \\
\hline
\end{tabular}




\subsection{The Capital City, Guanajuato}

Guanajuato, the capital city, is famous for its old city charm and is one of Mexico's most visited tourist destinations. It's also remembered for being the birthplace of Mexican Muralist Diego Rivera. Arguably, less known about the city is its quality public services and its remarkably transparent public budget. Citizens have access to monthly electronic newsletters, which include information on interest rates, current public investments, budget allocations and other general financial information. In addition, each year the state hosts an international transparency conference. The total population of the municipality of Guanajuato is 171,709 inhabitants, which represents three percent of the total state population.

The city government is composed of a mayor, 12 regiadores (elected council members) and two sindicatos (union members). To pass legislation, a majority of the municipal council must be present. The elected mayor selects the treasurer, private secretary and directors of public security, public services, infrastructure, economic development, and project management. From a national survey in 1995, there were 97 registered NGOs in Guanajuato, but that number jumped to 235 in 2000, increasing by some 142 percent (Santín 2004). These numbers suggest that the city and the state have been active in promoting civil society organizations. Table 7.4 lists the municipal presidents from the city of Guanajuato. In recent years, the city has been managed by PAN leadership.

\begin{tabular}{|lll|}
\hline \multicolumn{3}{|l|}{ Table 7.4 Guanajuato's (Capital) Municipal Presidents } \\
\hline $1980-1982$ & Edgardo Meave Torrescano & n/a \\
\hline $1983-1985$ & Rafael De Jesús Villagomez Mapez & PRD \\
\hline $1986-1988$ & Edgardo Meave Torrescano & n/a \\
\hline $1989-1981$ & Eduardo Knapp Aguilar & PRI \\
\hline $1992-1994$ & José Tomas Maclovio Zavala & n/a \\
\hline $1995-1997$ & Arnulfo Vázquez Nieto & PRI \\
\hline
\end{tabular}




\begin{tabular}{|lll|}
\hline $1998-2000$ & Luis Felipe Luna Obregón & PRI \\
\hline $2000-2003$ & Rafael De Jesús Villagomez Mapez & PRD \\
\hline $2003-2006$ & Arnulfo Vázquez Nieto & PRI \\
\hline $2006-2006$ & Antonio Valdes Fonseca & PAN \\
\hline $2006-2009$ & Eduardo Romero Hicks & PAN \\
\hline $2009-2012$ & Niceforo Alejandro de Jesús Guerrero Reynoso & PRI \\
\hline Source: (INAFED Instituto para el Federalismo y el Desarrollo Municipal 2010) \\
\hline
\end{tabular}

\section{Guanajuato Capital Municipal Finances}

In order to maintain stability in municipal public finances, public officials often trade positions. Both the mayor and the municipal treasurer of Guanajuato manage the city's budget. According to one public official, 40 years ago the mayor managed all budget decisions, but now there is a high reliance on the municipal treasurer, who is also a certified accountant. The current official has been city treasurer for nine years, or through three consecutive mayoral terms (which consist of three years terms). Because of the federal non-reelection law, with each new election cycle the mayor must nominate new staff. This consistence is a unique case for Guanajuato, since many local public officials replace all members of their staff leaving no records behind for the next administration. In Guanajuato, the municipal treasurer testified that his consecutive role as treasurer has helped to solidify the finances of the city and its public policies.

The city's financial solvency record is due to its well-educated municipal staff. For example, one public official propose that the city annexed the Museo de Los Momias (Mummy Museum), one of the country's archeological treasures. Since changing the administrative structure from the nation to the local government, the museum has generated more local revenue, totaling more than property tax revenues, rents, and fines combined. This translates into income for the city to invest in public works in order to strengthen the tourism sector of the local economy. To become more economically 
developed, the city has taken advantage of its historical importance. For example, Guanajuato is the first place where the Spanish extracted gold and silver within the Americas. As such, the city has developed a cultural tradition to celebrate the Cerventino street festival, which attracts tourists annually to the city.

The city's largest revenue source originates from the sale of entrance fees to the mummy museum. Other revenues are generated from 1) property taxes; 2) municipality fines and rents; and 3) general service fees such as for organizing events in public parks, charging for home sales and colleting funds from tourism for a cultural fund (which includes sales tax on general goods, rent of equipment and a special hotel tax). Of the nearly US\$ 33 million dollars generated by tourism in the state annually, nearly 35 percent, or approximately US\$12 million dollars, is returned to the local governments.

In the past, the state managed all collections of funds, but now the city has its own system for the management of its tax base. It was estimated that for each $\$ 1$ peso transferred from the state government, 20 percent of that goes to the municipality of Guanajuato. Figure 7.1 demonstrates the percentage of own-source revenue with is nearly the same as the total collection rates. 
Figure 7.1 Total Own-source Revenues in Guanajuato (capital)

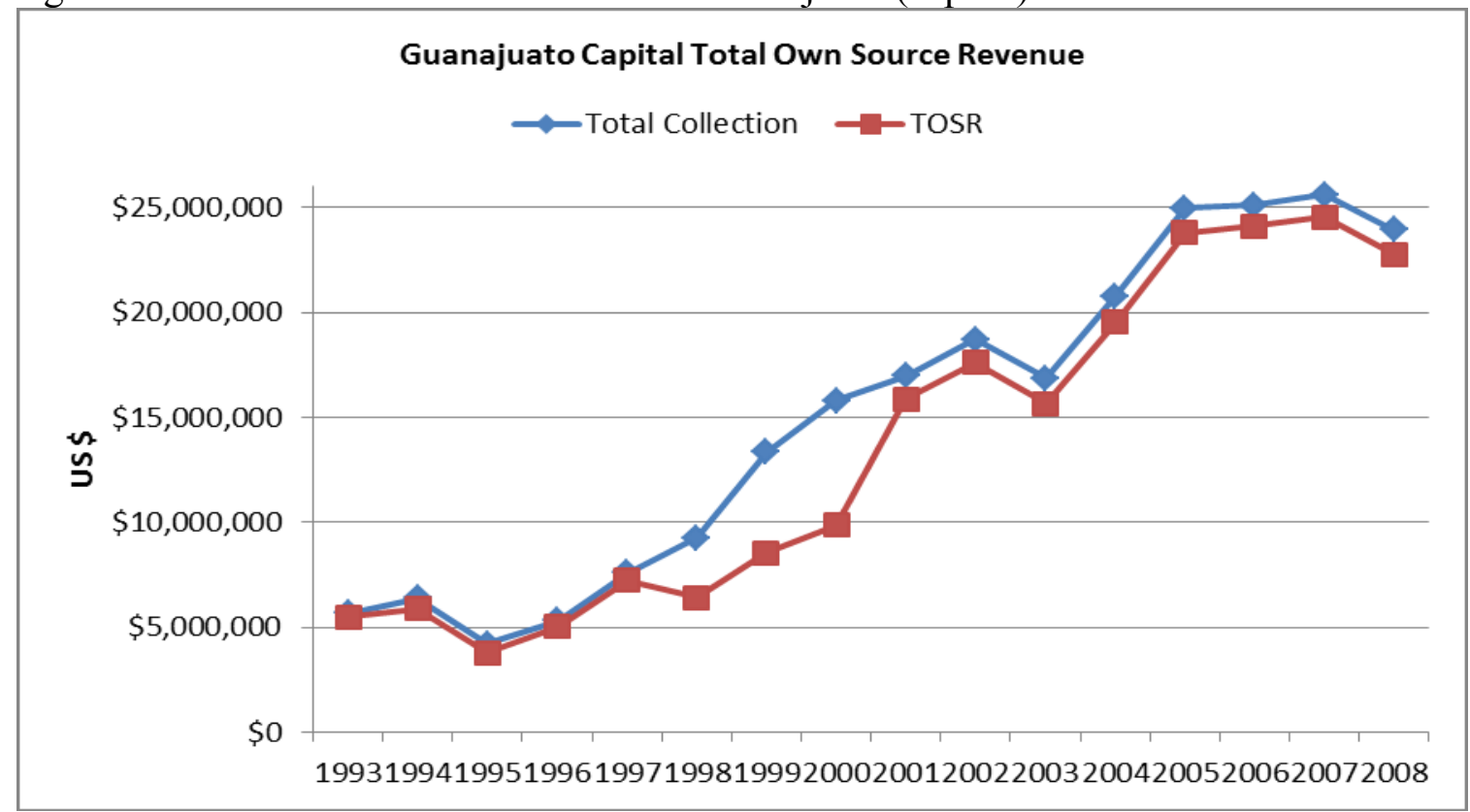

Source: INEGI

The large spike in the graphic after 1997 is due to revenue decentralization reforms at the federal level. The City of Guanajuato thereafter had more funds to allocate to the municipal projects. Of the federal transfers, the city receives an estimated 65 percent from Ramo 28 and 35 percent from Ramo 33. Ramo 33 has helped to strengthen local infrastructure. On the other hand, Ramo 28 can be spent on current expenditures, debt, and public projects. However, the municipality cannot pay for expenditures such public servants, which cannot be over 16 percent of recurring costs, with these funds.

From 2004 to 2009 the city increased its revenues by 45 percent, even with inflation rates at 4.5 to five percent. Nearly 25 percent of this increase came from fines, which increased from nearly $\$ 21$ million to $\$ 33$ million dollars over that period. Also the increase in local tax collection was helped when the city redefined its cadastre, which also systematized property tax payments and created a better auditing system. 
Figure 7.2 disaggregates the spending of the city of Guanajuato. Until only recently, little had been spent on wage bill and other operational expenditures within the municipality. Much of the budget, listed in the graph as transfers, has been returned to the state and national government as their part of revenues sharing system.

Figure 7.2 Disaggregated Spending in Guanajuato (capital)

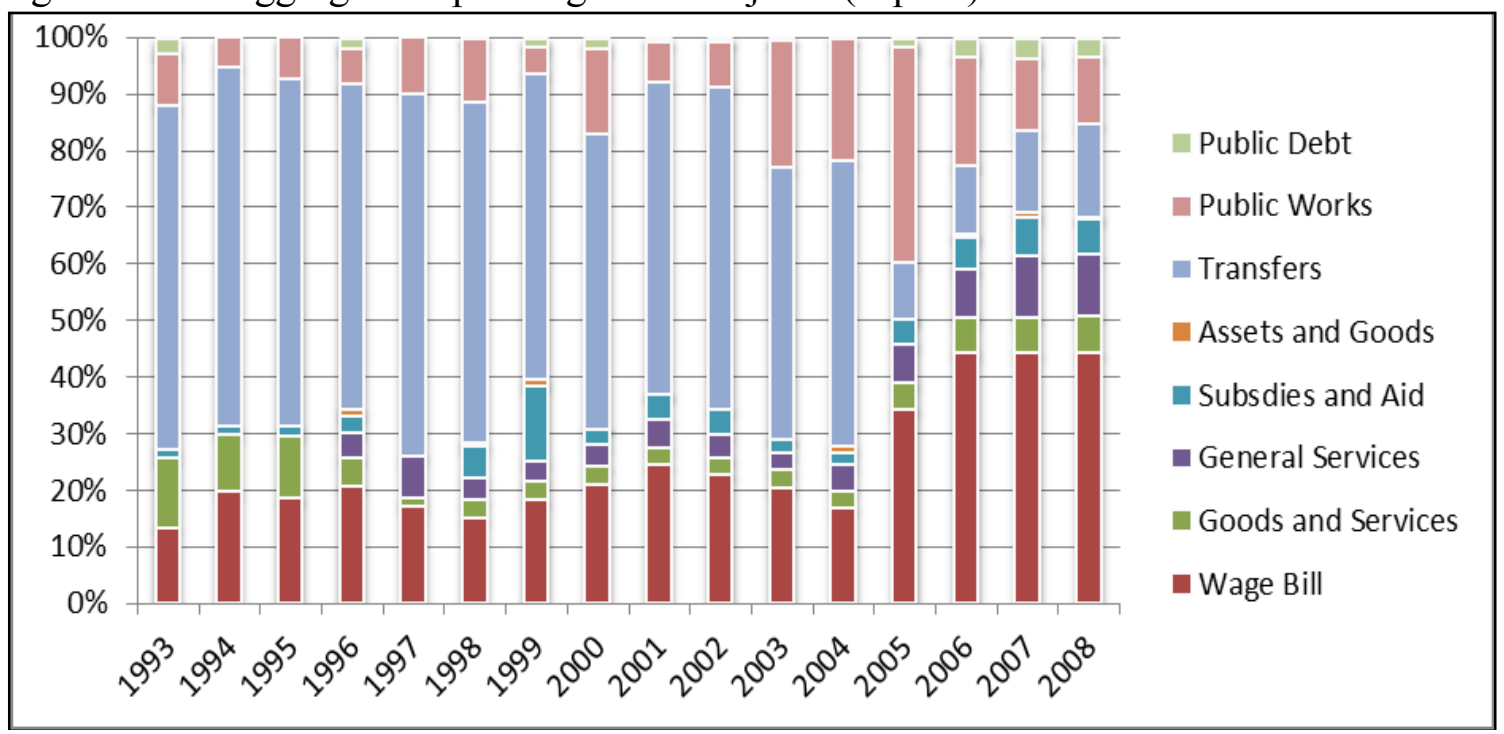

Source: INEGI

Social investment funds cannot be more than 17 percent of the total expenditures and are typically driven through transfers. These funds must be allocated for improving housing, school, and family assistance programs (DIF), which consists of six percent of Guanajuato's budget. Reoccurring expenditures, such as wage bill (public employment), operation and goods and services, were as low as 10 percent prior to 2004 and as high as 60 percent in 2008 . The city has nearly 1,500 employees. One way the city manages the budget is by eliminating spending on personnel.

In 2009, the city borrowed US\$3 million dollars from the Bank of Bajío at four percent annual interest set for ten years (this is the second of such loans beginning in 2005). The law prohibits long-term debt for current expenditures, but allows financing for infrastructure and development. In 2005, the city had a ten-year loan of US\$6 million 
dollars and received matching funds from Banobras. ${ }^{50}$ The city took advantage of the state's World Bank financing option, in which, it first paid back the other creditors, and made a programmatic decision to create improvements in the city for the tourism sector.

\section{Guanajuato City's Local Economy}

The economic base of the municipality of Guanajuato includes approximately ten percent farming income, 32 percent manufacturing and 53 percent commercial activities. Approximately 79,000 people are in the labor market. Of which, 88 percent of the population is between 14-47 of age. Table 7.9 describes the trends of employment within the city.

\begin{tabular}{|c|c|c|c|c|c|}
\hline \multicolumn{6}{|c|}{ 7.5 Guanajuato's Economically Active Population (over 12 years of age) } \\
\hline \multirow{2}{*}{$\operatorname{Sex}$} & \multirow{2}{*}{ Total } & \multicolumn{2}{|c|}{ Active percent of the population } & \multirow{2}{*}{$\begin{array}{l}\text { Inactive percent } \\
\text { the population }\end{array}$} & \multirow{2}{*}{ Not Specified } \\
\hline & & Employed & Unemployed & & \\
\hline Municipality & 100,737 & 48,121 & 526 & $\mathbf{5 1 , 5 5 7}$ & 533 \\
\hline Men & 47975 & 32,004 & 397 & 15,281 & 293 \\
\hline Women & 52762 & 16,117 & 129 & 36,276 & 240 \\
\hline Source: (INAF & ED Insti & tuto para el F & alismo y el Desa & Municipal 2010) & \\
\hline
\end{tabular}

The major sectors of the economy for the municipality of Guanajuato include agriculture, mining, and tourism. Tourism is very important for the city, which has an abundant amount of rich cultural and artistic heritage, including monuments, buildings, museums, plazas, squares, and temples in the downtown. Building dates back to as early as the colonial era. Also, the city has a wide range of professional services, mainly for tourists, such as banking, culture shops and leisure activities are located there. Table 7.6 disaggregates the active sectors in the economy.

\footnotetext{
50 Trust funds (fidecomisios) are instruments used by the state and municipalities to finance projects. The funds are put into separate accounts and receive national backing by the automatic payments from of Ramo 28 , which are the unconditional transfers from the federal treasury to the state governments.
} 


\begin{tabular}{|lll|}
\hline 7.6 Guanajuato's Economically & Active Population by Sector \\
Sector & $\begin{array}{l}\text { Economic } \\
\text { Census }\end{array}$ & Employed \\
Total & $\mathbf{3 ~ 6 1 1}$ & $\mathbf{1 9 0 0 0}$ \\
Fishing & $\mathrm{n} / \mathrm{a}$ & 18 \\
Mining and Extraction Industries & $\mathrm{n} /$ & 2366 \\
Manufacturing & 356 & 1559 \\
Construction & 87 & 3475 \\
Commercial Operations & 1867 & 4352 \\
Transport and Communication & 100 & 1328 \\
Private Services not Financial & 1186 & 5902 \\
Source: (INAFED Instituto para el Federalismo y el Desarrollo Municipal 2010)
\end{tabular}

Arguably, agricultural development is low because of the steep landscape. However, the main crops are sorghum, alfalfa, peanuts, and fruit, animal husbandry. Typically, farmers raise cattle, goats, and sheep. Mining is the activity that gave rise to the city of Guanajuato. Today, gold mining is minimal, but silver, lead, and kaolin have taken its place, and are currently being excavated in Guanajuato.

Guanajuato's Economic Development Efforts

Arguably, the city of Guanajuato has two major mechanisms to strengthen its economic development for the region. The first is through the leveraging of its public finances for project, and secondly, is the traditional establishment of an office of economic development. For example, the city's current economic development plan, through the use of these available public finances, is to "improve its urban vision," which consists of a 12 step plan to improve streets, sidewalks, and monuments. According to one public official, the principal decision to take out private debt was to restore public areas and fix streets, urban stores fronts and pavement. Nearly US\$1.5 million dollars of the World Bank loan were dedicated to construction projects and the remaining was used to pay off past city debts. 
The city of Guanajuato's economic development (LED) office provides programs to strengthen the local and regional economy. The 2009 local economic development budget was approximately $\$ 385,000$ dollars. ${ }^{51}$ The total included the contributions of 39 percent from the state; 43 percent from the municipality; 15 percent from the federal government and only three percent from the private sector. The funding helps to support various sectors in the economy such as art production ( 8 percent of the local budget), service sector (ten percent), financial development (18 percent), micro-credit (23 percent) and tourism-related activities (18 percent).

The economic development director identified that the city faces three major problems in order to improve its economy. These include: 1) the reputation of the arduous legal requirements which leads to long set-up times for small businesses; 2) the legal framework itself, which does not help attract small businesses; and 3) the lack of fiscal incentives to attract new businesses to work within the municipality.

One public administrator had a very progressive vision of the city's local economic development policies. He focuses more on small business production and providing assistance to locally produced industry, rather than attracting new foreign owned business into the area. Apparently, in recent years the major American big-box retailer, Wal-Mart wanted to establish a store within the city limits. He suggested the following contradiction:

Creating an industrial park is valued, but it generally, generates more questions than answers, especially for a place with such high inequality like the State of Guanajuato. For example, specifically for the workers in the unions and their families, who from the city would be assigned to negotiate with them? Second, in understanding the concept of innovation: the public official suggested that when there is such a low level of professional development, who from Guanajuato would

51 This is a small percentage in the overall budget of the city. 
work these jobs? Additionally, concepts such as industrial cleanup could be problematic. Finally, and a future possibility could be the production of software would be idea for the region, but the LED profession questioned where the investors would come from?

The city has major connections with the private sector through organization of chambers of commerce and works actively to engage them to produce better public policies. This pragmatic view demonstrates the reality that many highly qualified public officials face in a territory with a small and underdeveloped private sector.

Even with these successes to promote economic development and fiscal autonomy, one public official suggested that the mayor has a wish list of improvements, which included receiving additional transfers from the national government. Notwithstanding, it efforts to be fiscally autonomous, one public official projected the need for up to 30 percent of the budget to be transferred from the national government for public projects such as for water expansion and rubbish collection systems.

Public officials agreed that outside NGOs can help the social welfare of the population, but is not enough. For instance, if an NGO helps 100 people, there are an additional one thousand people in the city that need help. In one interview, a public administrator suggested that this is why a strong local government is needed, to cover the social costs of the society left by the marketplace.

Another recommendation from a public official in Guanajuato was to make the city even more economically developed. He observed that it was during Lopez Portillo's presidency (1976-82) when the role of municipal development started to become increasingly important, especially with the use of trust funds for development projects. The decentralization process, in this administrator's perspective, is not complete. 
According to one public official, "administrative reforms should include either reelection of municipal office for two administrations for a total of six years or became mayor for a total of four years in order to get everything done." He added, "in order to have successful planning, a mayor needs more time in office."

Finally, the level of professional development of the municipal staff is relatively high in Guanajuato, which could account for the public projects and sustainable public finances. Public finances have to been used as an innovative approach for driving economic development. For example, the mayor's office request to the federal archeological agency to transferred management responsibilities, first the state agency, and later to the city to be managed rendered increasing the tax base by 40 percent. The idea in and of itself, is innovative but also has helped the city to leverage other debt finances for additional projects.

Another example is the use of pension funds for financing project. Through a national law, the retirement accounts (AFORES) can be used for public investments. Many cities do not take advantage of these accounts in Mexico, because one wants to take the risk to default on the AFORES loans. Higher capacity means more project development. For example, the City's Public Works office (Secretaría de Obra Pública) used the city's AFORES, pension fund, to fund a parking lot and commercial center and had recuperated accrued75 percent of the investment by 2009. Overall, the level of professional development (e.g. education, training and skills) of public employees matters to their technical ability to establish and manage projects. 


\subsection{San Miguel de Allende}

This city is most notable for September 13, 1810, the day when Ignacio Perez arrived in town to report that the country had declared independence from Spain. San Miguel de Allende (SMA) is a mid-size town within Guanajuato that has a large amount of tourism, an artist community, and increasingly, a larger amount of foreign-born residents who enjoy both its beauty and the arts community. The cases examines that American residents heavily influence on the city and its prospects for economic development with additional financial resources. In respect to the fiscal solvency of the municipal budget, San Miguel is the case that has increased its wealth by the effect of having affluent migrants living in the community. The city also increased its property values in order to provide more financial revenues to improve municipal programs.

It was during the Spanish occupation in the early 16th century that the region became known for its renaissance of art and culture. Since then, the town has attracted a very large number of foreign retirees, artists, writers, and tourists, which have shifted the economy of the area from agriculture and industry to commerce, catering to these outside foreign visitors and expatriate residents. Beginning in the 1950s, many Americans stated to travel to SMA in pursuit of its artist colony. ${ }^{52}$ The foreign influence is one of the major influencing factors to select and analyze the case of San Miguel de Allende.

The population San Miguel shows significant population grew significantly from 1980 to 2000 and more gradual growth thereafter. After this first population boom, the

\footnotetext{
52 Several famous artists have spent time in San Miguel. For example, "In 1960, Jack Kerouac, the novelist who had catapulted to fame three years earlier with the publication of On the Road, went to San Miguel with pals Allen Ginsburg and Neal Cassady. Ginsburg read his poetry at the Instituto Allende, while Kerouac and Cassady spent most of their time downing tequilas at La Cucaracha, a traditional Mexican cantina that remains popular to this day. The trio remained only a few days, but in 1968, Cassady returned to San Miguel, where he died at age 41 from the effects of alcohol" (Smithsonian Publication).
} 
regional annual average was 2.18 percent after 2000. Many people in San Miguel live in rural areas within the municipality. Considering the population over five years, by 1995 there were a total of 118,769 people born in the municipality of Allende, of which 3.68 percent had their residency in another state or country. This is an important statistic since the state of Guanajuato is number five in the nation for outgoing migration. Many foreigners are finding San Miguel de Allende their home. American retirees are not listed into the official census data because several live only parts of the year in San Miguel de Allende, but are the largest portion of foreigners. Table 7.7 demonstrates the population increases.

\begin{tabular}{|lllll|}
\hline 7.7 Population of the Municipality of San Miguel de & Allende \\
Year & $\mathbf{1 9 8 0}$ & $\mathbf{1 9 9 0}$ & $\mathbf{1 9 9 5}$ & $\mathbf{2 0 0 0}$ \\
Total & 77,624 & 110,692 & 118,769 & 134,880 \\
\% of State Pop & 2.58 & 2.78 & 2.70 & 2.89 \\
Source: & INEGI 1981; INEGI 1991; INEGI 1996, INEGI 2000. \\
\hline
\end{tabular}

\section{SMA's Political Environment}

The city of San Miguel de Allende has over 950 small communities of less than 2,500 people in its surrounding area. ${ }^{53}$ Ten commissioners (Regidores) are based in the municipality of Allende. In 2009, the municipality's annual budget was approximately $\$ 35$ million dollars, of which it spends most of it on administrative costs. One public official estimated that the city spends nearly $\$ 10$ million dollars a year on salaries alone. The conservative PAN national party outweighs the city politics, although there is also local representation by the PVEM, PRD, and PRI. ${ }^{54}$ In the last election in 2009, the

\footnotetext{
53 Mexico's major administrative divisions for local governments are municipalities (like US counties). Cities may be located within a particular municipality, but are counted by the census as municipalities.

54 Partido Verde Ecologista de México (PVEM) or the Green Party in Mexico was created in 1979 as an alternative party to the dominate PRI, but is often described as co-opted by the PRI. The green party aligns itself with the anti-abortion debate and other ideas that are not relate to the environment.
} 
mayor and commissionaires changed. Under Mayor José Jesús Correa Ramírez (200609), the municipality's representatives included five PAN, three PRD members, and one member each from the PT (workers party) and the PAN. Luz Maria "Lucy" Nunez Flores, the city's first female mayor, was elected and manages a municipal council of four PAN, three PRI, two PRD, and one member from the PVEM party. Table 5.8 is a list of the previous past municipal presidents in San Miguel de Allende.

\begin{tabular}{|lll|}
\hline Table 7.8 & SMA's Municipal Presidents & \\
1980-1982 & Pedro Gerez Diez & PRI \\
1983-1985 & Luis Ferro de la Sota & PRI \\
1986-1988 & Ernesto Villagómez & PRI \\
1989-1991 & Manuel Zavala Ramírez & PRI \\
1992-1994 & Salvador García González & PAN \\
$1995-1997$ & Jaime Michael Fernández Martínez Harris & PRI \\
1998-2000 & Salvador García González & PAN \\
2000-2003 & Oscar Arroyo Delgado & PAN \\
$2003-2006$ & Luis Alberto Villarreal García & PAN \\
2006-2009 & José Jesús Correa Ramírez & PAN \\
2009-2012 & Luz Maria Nuñez Flores & Umbrella Party \\
Source: (INAFED 2010) & \\
\hline
\end{tabular}

Unlike most of the country, the local green party has established itself within the municipality and has its own flourishing agenda. One council member representing the PVEM was previously the city's ecology director prior to running for public office. ${ }^{55}$ During his tenure, this public administrator set up the Fondo Verde, which was a publicprivate fund to encourage citizens to pay for municipal ecological services. Since its creation in mid-2006, the fund has accumulated over $\$ 1$ million dollar to promote greening practices in municipal laws and legislation. The idea was supported by local civil society organizations that composed of many of the foreign born residents, such as

55 This Commissioner stated that he had never imagined becoming a county commissioner, but became increasingly engaged in the green agenda after finishing a master's degree in international law in the United States. Shortly after returning home, he worked in the local administration, but after five years, he could not continue in that position and had to run as a commissioner in order to continue the work within the municipality. 
the Audubon society, the Lion's and Rotary clubs. A public committee oversees the fund, and it is comprised of both citizens and government officials to approve projects. Local projects include improvements in riverbeds, walkways, and trash removal from local streets. The idea of the green fund was started in 2005 to help pay for public park improvements. The public official suggested that the municipality could add additional budget funds, by increasing sales on property or by an increasing two percent tax tourism tax. Several states have copied the idea of the Fondo Verde.

\section{San Miguel's Municipal Finances}

The municipal budget in San Miguel de Allende is rather small. The annual budget is estimated to be around US\$30 million dollars, where US\$10 million are collected locally, US\$15 million are transferred from federal funds and US\$5 million from the State of Guanajuato. Nearly one quarter of the local tax collection comes from property taxes. In 2009, the city had taken out public debt of nine years at an interest rate of 1.5 percent, which was financed through Banobras.

One public official indicated that cutting excesses within the municipality is done by not offering overtime to employees, which is critical to maintain a balanced budget. He admitted that the municipality had problems by simply offering too many benefit to staff. Benefits are another way that city spends its budget on human resources. Figure 7.3 disaggregates spending for San Miguel de Allende. In effect, wage bill was as high as 50 percent in 1998 and decreased to less than 20 percent in 2008. The percentages of these expenditures are in Figure 7.3. 
Figure 7.3 Disaggregated Spending in San Miguel de Allende

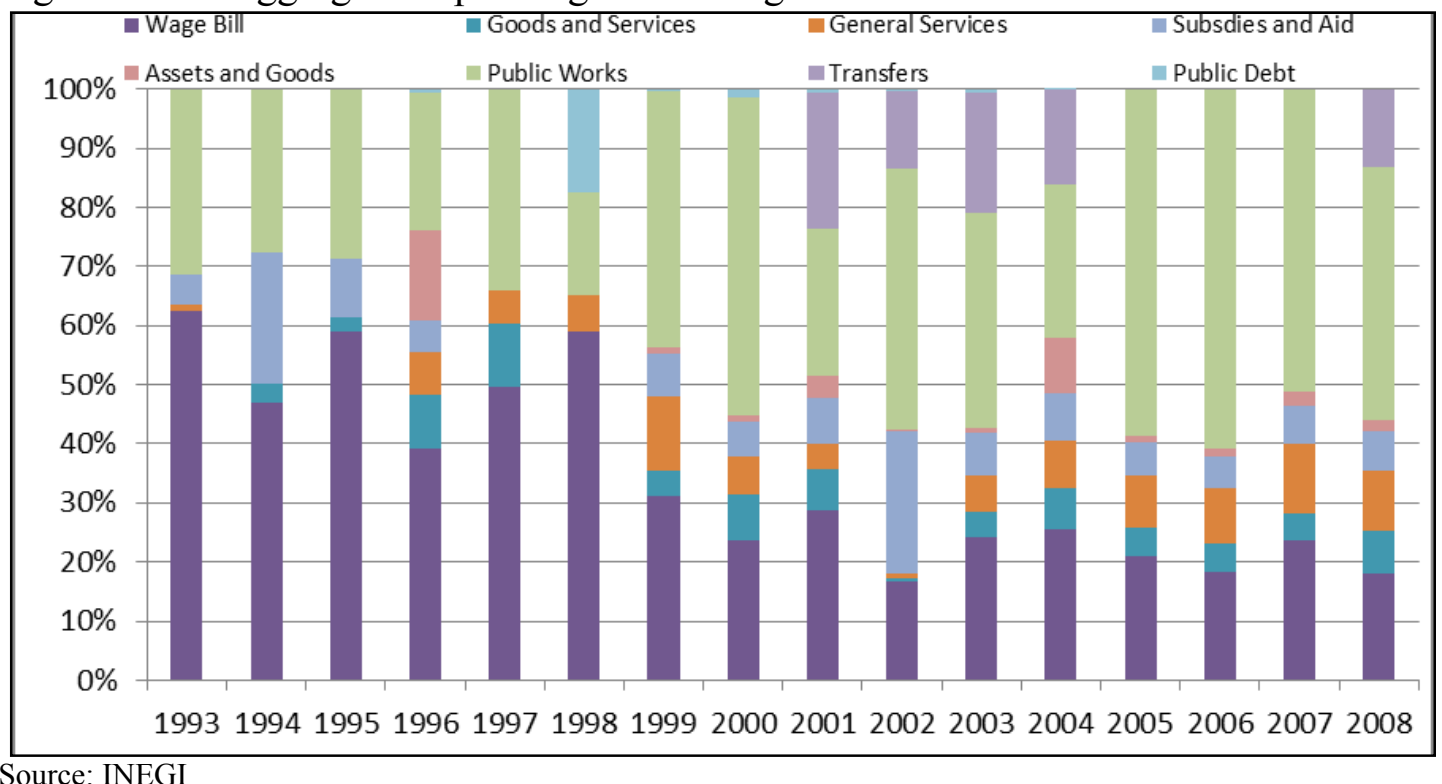

The budget expenses include a large portion for wage bill. The next highest expense includes public works and lesser so, goods and services and finally payments from national government transfers (Ramo 28). Figure 7.4 describes the total own-source revenue (TOSR) verse the total collection (budget) for the city. After the decentralization law in 1997, the increase in the total budget increased substantially, yet the TOSR has stayed relatively the same even dropping in 2003 and again in 2006. 
Figure 7.4 Total Own-source Revenues in San Miguel de Allende

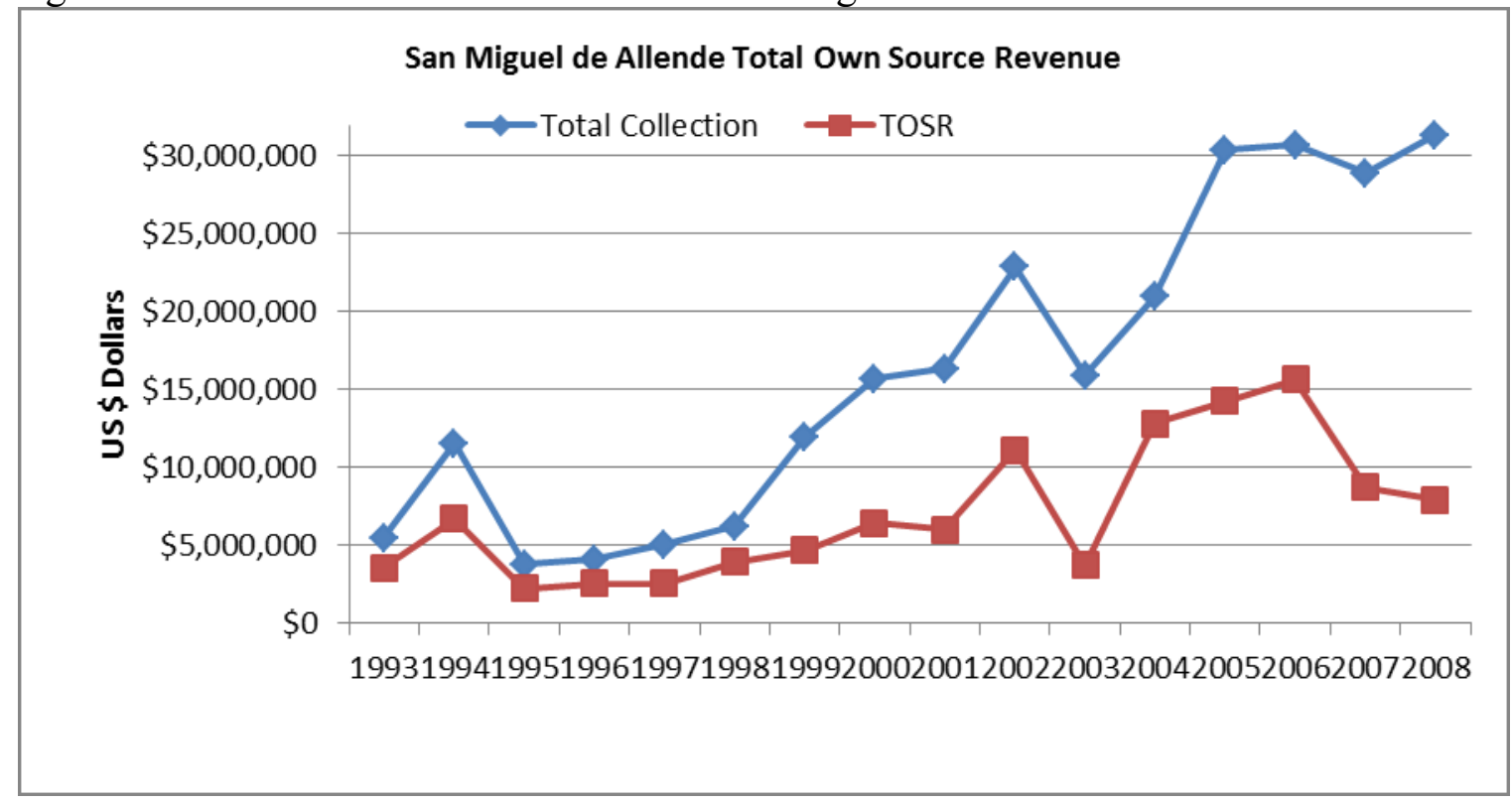

Source: INEGI

The local budget is posted annually on the Website as the government's report. Generally, estimations of the budget's expenses include 50 percent for public works (which is composed of half local funds, and the rest divided by national and state funds); 25 percent social programs, where 80 percent comes from the national Social Fund; and the remaining 25 percent are used for the municipality's operations. The municipal staff totals 911 employees.

San Miguel's Local Economy

Tourism in SMA is the most significant private industry for the city. Tourists come from around the world to see the art and high quality museums and cathedral. The second major economic force that has driven the local population of San Miguel de Allende is the inward migration of foreigners. Other areas that have strengthened the local economy also include agriculture activities, such as forestry, and minimal amounts of industrial and trade activities. In the municipality of Allende activities related to the primary sector (agriculture) generate 25 percent of all jobs. Moreover, despite being one of the 
municipalities with a greater number of poultry, egg production represents a low percentage compared to the state's production. Table 7.9 describes the types of business that San Miguel de Allende has compared to the State's activities

\begin{tabular}{|lccc|}
\hline \multicolumn{4}{|c|}{ Table 7.9 Division of the business sector in SMA in 1998} \\
Retail & Total & SMA & State \\
SMEs & 66,895 & 29,877 & 37,018 \\
The numbers include a sum of jobs created by sector. Source: Censo Económico 1999. INEGI & 48,508 & 152,005 \\
\hline
\end{tabular}

Infrastructure development has played a large role in the development of Rural Zones for the area. For example, additional access to areas of the municipality through the pavement of roads has improved over the past few years. According to one public official, the development of a shopping center, which is located just outside the city center of San Miguel de Allende, has created many jobs. New housing construction was also going on throughout the early 2000s, until the recent economic downturn in 2008 . As a result, the San Miguel de Allende is now faced with an influence of large disparities of wealth, and thus, security problems for these new properties.

Another recent change is the improvements in education levels across the San Miguel de Allende. The city's student population is concentrated mainly in the primary levels. On the other hand, high school and professional levels students are very low. Considering the rate of the population of the municipality with respect to the state $(2.9$ percent) the municipality has a shortfall in state averages. Two colleges located in San Miguel de Allende, the Universidad del Valle de Mexico and University of Leon campus, which both offer four professional degrees.

Additionally, the society in San Miguel de Allende has accepted the influx of more Americans living in the county. One public official has noted that there has been an 
indirect influence having the Americans living in San Miguel de Allende. According to him, it is not that the gringos are helping with more social programs, but they are adding to the federation's efforts to social development, for him, "Just a bit more is all that it takes to make the municipality much better."

San Miguel de Allende's Economic Development Efforts

Another approach to local economic development comes directly from the expat community. One local American artist commented that his grandmother migrated to San Miguel in the 1920s because she was attracted to the artist colony. His father followed her after World War II. He, himself, grew up in the United States, but finally moved permanently to San Miguel de Allende, after going back and forth from Cape Cod, Mass throughout much of the 80s and 90s. In 2009, the American described a plan to build an art school in the area to attract international attention for San Miguel de Allende. The idea was to build a school with all its modern conventions, with classrooms and studios was to attract quality arts students. He and a group of local artists planned to hire a Ricardo Ligaretta, a highly renowned Mexican developer and architecture, to design the school.

The idea for the arts school provides an example for how the foreigners are influencing the economic development in San Miguel de Allende. The American suggested that the project named the San Miguel Institute would bring a large-scale business of Americans to study fine art to Mexico. The business plan aims at providing short-term classes for American and European retirees. The construction project was estimated to be over $\$ 1.2$ million dollars in 2009. "That sort of capital to start an arts school would be unthinkable for a small municipality with minimal amounts of 
administrative support and small amounts of direct programming budget for its yearly activities" accounted one public official.

Additional efforts to promote economic development come from the municipal office of the environment. The surrounding forests provide much of the economic activity. Reforestation is important part of this. In 1992, the city planted more than 14,000 trees in an area of 14.6 hectares, representing 1.7 percent of the forested areas of the state. By 1998 these numbers increased to some 660,000 trees planted in an area of 294 thousand hectares. In 2000, the city planted 12,500 trees with a reforested area of 12.5 hectares. In 2009, the environment office had received between 60 and 100 proposals to improve the local environmental quality, many of which have come from the foreigners living in the area.

One public official suggested that engagement with civil society has been difficult. Apparently San Miguel hosts the largest international section of the Audubon Society, with some 300 members. According to this public administrator, the members only have demands and no solutions to public problems. He stated, "even if they use their memberships to plan programs, it would help." One public official highlighted that the local NGOS create demands but do provide support or develop feasible solutions to public problems. The city has reached out internationally and has created partnerships with Brandies University in Boston and Eco Systems Sciences in Boise Idaho, which have helped to contribute to pay for salaries of two local staff members.

Further civic engagement comes directly from foreigners who have set up their causes locally. For example, one American, who has lived in San Miguel for many years and is currently the president of the local library, which he runs as an NGO. The library 
was an American invention after two women in the 1950s started to bring books to San Miguel to teach children to read. Finally, they convinced the city of San Miguel de Allende to donate a building, which was formally a slaughterhouse for pigs. The library has for the past 20 years has operated as an arts and cultural center. Currently, it also has a café and English bookshop. In an interview, the director suggested that there have been several comments lately from the senior residents complaining about the children running in the halls. The library is a public space and welcomes not only American expats but also the local Mexican residents from San Miguel. The primary extracurricular activity is teaching English, which is the primary language of the library. Singing, poetry, video projection, painting, and reading classes are also offered to the city's youth.

Another American NGO in San Miguel is a self-defined a pro-Marxist organization. This NGO aims to strengthen women's employment and find alternative ways to fight globalization (defined as the negative effects caused by NAFTA to small industries and the informal sector employees). The group has been in operation for approximately five years and has enlisted interns to work in community development projects around the city. The director suggested that they recruit participants from across the world and have placements for short-term work and long-term assignments. The NGO encourages foreign volunteers to be involved in local community activities.

With the influx of foreigners, social tensions do exist in San Miguel de Allende. Divisions between residents, whether they were foreign born or local Mexicans, do exist. Racism creates tension between the two communities. For example, the library has seen some violation of its property from the Mexican residents. The Mexican residents also feel invaded by the gringos in their local community. Additionally, division among the 
foreign residents exist as well, between the "do-gooder" Americans trying to help the locals and other retirees enjoying the last of their elderly years. Although many residents who enjoy having the gringos in their community. Several youth have received scholarships to attend school and others have after school jobs from the gringos. There are good prospects for these groups to come together. For example in 2009, the MayorElect Lucy Nunez presented her platform speech in English to the gringo community. Even if the American expat community could not vote in the local election, the local politician saw the community as an important on with which to engage.

\subsection{The City of Leon}

The city of Leon is known for being the shoe capital of Mexico. Traditionally, it has been the center for the creation and design of Mexico's shoe industry. This derives from leather, which comes from the cowherds surrounding the Bajío. The city is one of the largest within the state with a total population of $1,134,842$ inhabitants. ${ }^{56}$ It has a flourishing local government, from which many state and national leaders have originated. The city has engaged in spatial economic development programs, to strengthen its local regional corridors. Away from the main plaza and city center, the next concentric circle is made-up of low-income residents, but the surrounding areas include strip malls, American style shopping centers and easy access to the major highways.

\footnotetext{
56 The municipality of León contributes 24.35 percent of the total state population in 2000. Leon ranks first in the state of Guanajuato in population. Of that total 48.88\% (554.690 inhabitants) are male and 51.12\% (580.152 inhabitants) remaining women.
} 


\begin{tabular}{|c|c|c|}
\hline \multicolumn{3}{|c|}{ Table 7.10 Municipal Presidents of Leon } \\
\hline Harold Gabriel Appelt & $1980-1982$ & PRI \\
\hline Rodolfo Padilla Padilla & $1982-1984$ & PRI \\
\hline Antonio Torres Gómez & $1984-1985$ & Substitute \\
\hline Antonio Hernández Ornelas & $1986-1987$ & PRI \\
\hline Arturo Villegas Torres & $1987-1988$ & Substitute \\
\hline Carlos Medina Plascencia & 1989-1991 & PAN \\
\hline Facundo Castro Chávez & 1991 & Substitute \\
\hline Eliseo Martínez Pérez & 1992-1994 & PAN \\
\hline Luis M. Quirós Echegaray & $1995-1997$ & PAN \\
\hline Jorge Carlos Obregón Serrano & $1998-2000$ & PAN \\
\hline Luis Ernesto Ayala Torres & $2000-2003$ & PAN \\
\hline Ricardo Alaniz Posada & $2003-2006$ & PAN \\
\hline Vicente Guerrero Reynoso & $2006-2009$ & PAN \\
\hline Francisco Ricardo Sheffield Padilla & $2009-2012$ & PAN \\
\hline
\end{tabular}

The municipal government of León is managed by the mayor and has 12 councilpersons, of which six are elected by plurality from a list or by large. Of the remaining six, two are city union members (sindiadisos) and four are selected by proportional representation. Below is a list of municipal presidents from Leon, many of which are PAN members, especially after 1992 (one year after Vicente Fox's contested gubernatorial election).

\section{Leon's Municipal finances}

In 2009, the City of Leon managed a budget of US\$169 million dollars. The previous municipal treasurer was fired and charged with embezzlement in $2010 .{ }^{57} \mathrm{He}$ served the city through two administrations from 1992-97 and again from 2006-09. In an interview in 2009, prior to his arrest, one public official provided an explanation as to

\footnotetext{
57 Apparently, the Municipal Treasury and his employees invested 37 million pesos in the Sofom, Metrofinanciera for which the company lost its investment shares, and therfore lost the public funds doing speclative invesments. He received a 900-day penalty fine equivalent to the amount of 46000755 pesos, and five years of ineligibility to return to office. (Flores, Lourdes. 2009. "Pierde dinero León al quebrar Metrofinanciera." in Milenio. Nevo Leon, Mexico, The City of Leon. 2009. "Inhabilitan a Ex Tesorero." vol. 2011. Leon, Mexico.)
} 
why the city of Leon is an integral component of economic development and finances for the state.

The product of public investment, the city has increased its economic development. Leon was rated from S\&P as AAMx and Moody's as Baa3 for its municipal debt. The city has public debt of approximately $\$ 125$ million pesos (which is approximately US\$10 million dollars) as its local budget from Banco Bajío. The city employee's trust fund, Fidecomicio de Obras de Coparciado (FIDOC), was created with 40 percent state, 20 percent neighborhoods, and 40 percent municipal financing was used as collateral. Leon is one of the largest cities in Mexico. The municipality meets with the G10, which is a conglomeration of the largest city governments of Mexico, which was established by President Fox.

The city's total local budget is described in figure 7.5. Of the total budget, 43 percent is collected locally compared to the 57 percent received in transfers from the national government. Leon's TOSR has been proportional to its total budget but continuously but drastically decreased after the 1997 federal decentralization law. 
Figure 7.5 shows the percentage of TOSR collected by the municipality of Leon.

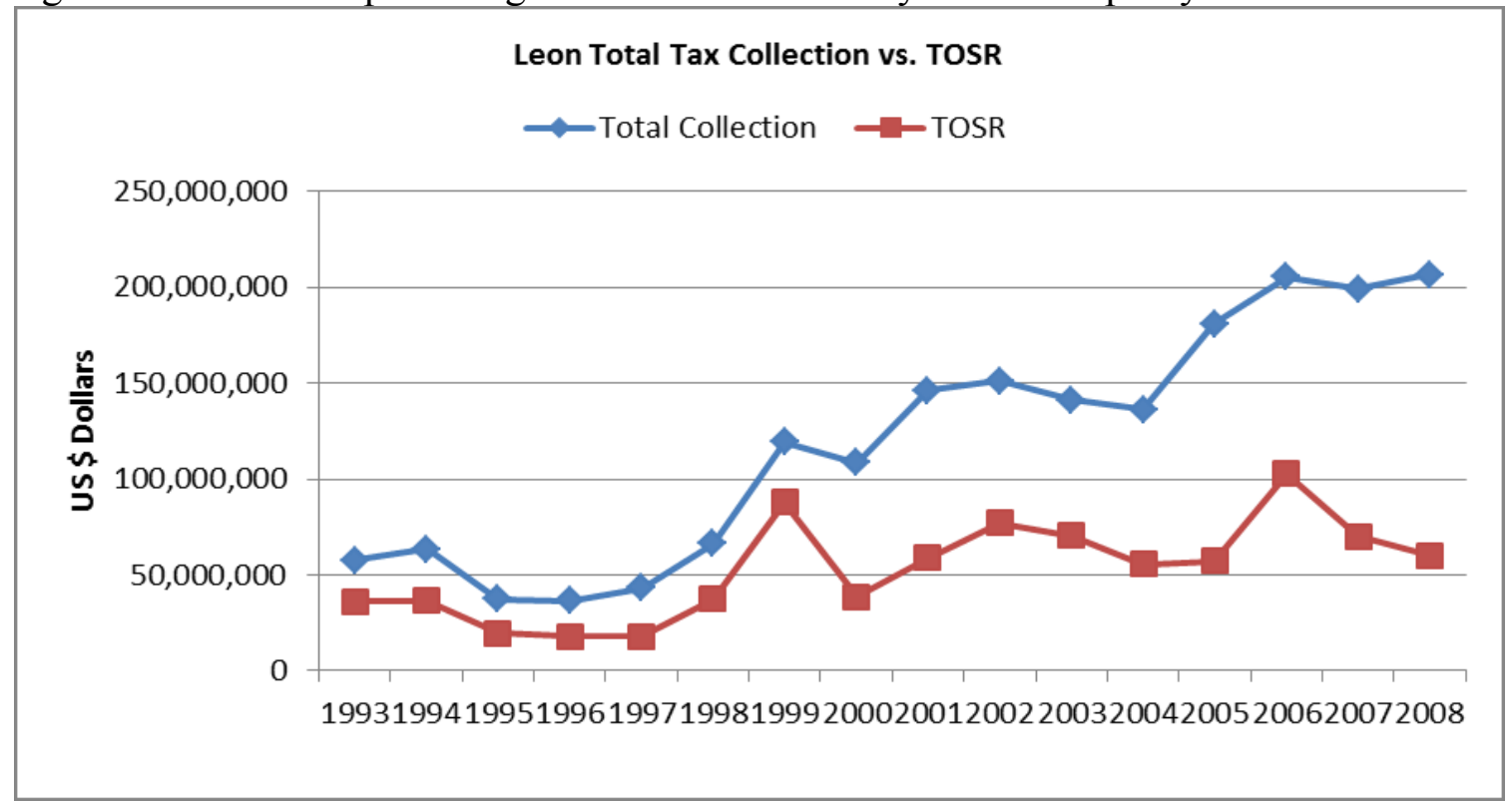

Source: INEGI

Figure 7.6 presents the amount of spending for the city of Leon. The city spends nearly 30 percent on its public employees (wage bill), which is the highest expenditures. The next highest expenditure is funds from transfers, which are typically redistributed for social policies. The other areas of expenditures include assets, subsidies, services, public works, and a very small amount for public debt.

Figure 7.6 Leon's Disaggregated Spending (1993-2008)

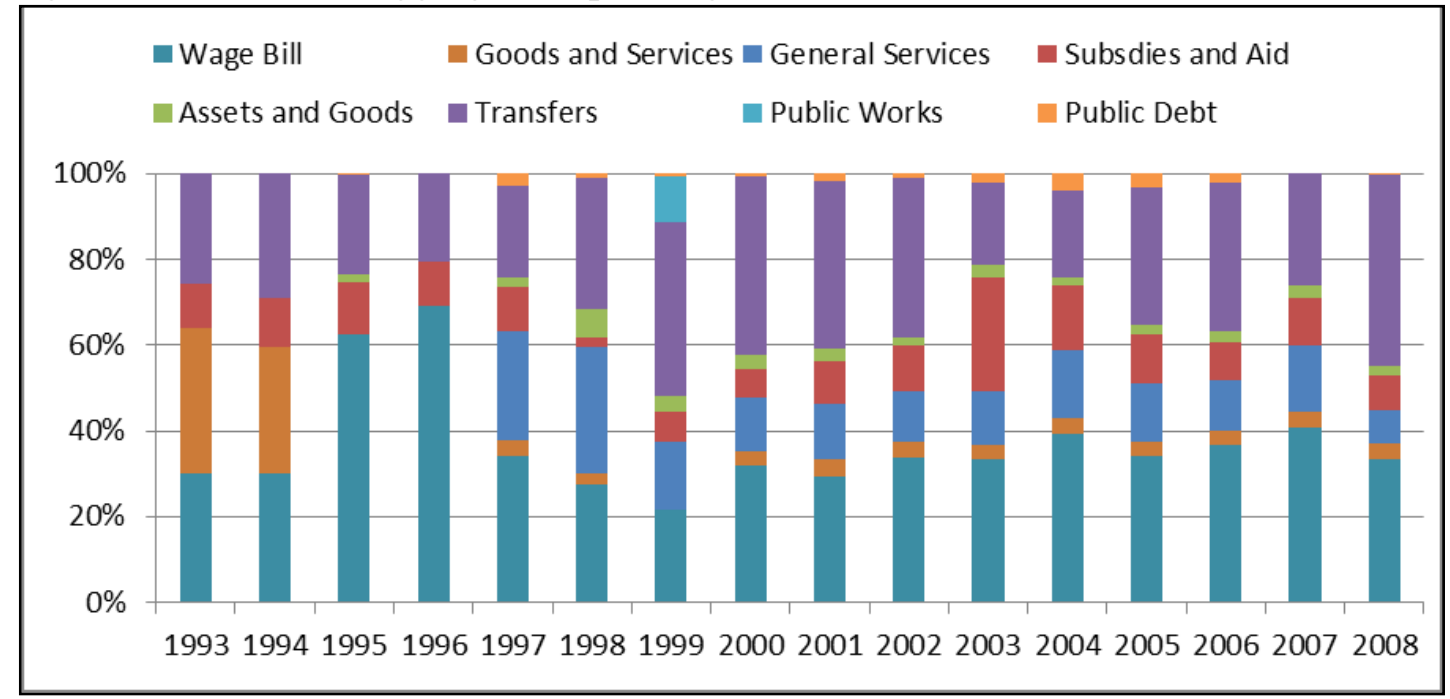

Source: INEGI 
The city took out its first public loan under the first PAN administration of Mayor Carlos Medina Placencia, prior to him becoming Governor. In 1992, the second PAN Mayor Eliseo Martinez Perez initiated an increase in urban development activities by improving property tax collection. At that time, the city restructured its cadastre, reapplying a new property tax structure. This involved hiring small crop airplanes to fly over the territory and take photographs of city lots. With airplane scans, the city government hired a cartographer to evaluate the land. Shortly thereafter, the city government requested that the public pay an estimated tax rate for their property. If a citizen did not pay the new rate, the city would charge the new rate plus five years of back payments. This encouraged people to pay for their effective value of their property. As a result from these measures, according to one public official, the municipality increased its tax revenue by 92 percent. ${ }^{58}$ One municipal administrator admired the party leadership of the PAN for improving the tax rolls.

In 2003, Mayor Luis Ernesto Ayala Torres increased the city's tax revenue again through the creation of a new administrative office. The Offices of the Treasury, Cadastre, and Development Planning (IMPLAN for is acronym in Spanish) merged the procurement system, land management and tax collect efforts into one office. The municipality bought a computer server to evaluate propriety online, which also combined with the citizens' tax bills through Internet-based payments. The state's planning office (IPLANEG for is acronym in Spanish) merged its function, therefore revised property taxes schemes were assign for new construction.

\footnotetext{
58 According to one public official, from 1997 to 2009, levies to property taxes went from $\$ 40$ million pesos to $\$ 3,500$ million pesos in tax revenue.
} 
The city of Leon has a low-interest rate for their public loan is at two percent. The city liquidated its 1990s public debt with the new World Bank loan. Because the loan was set in local currency (pesos) instead of U.S. dollars, the city managed a lower repayment prate. This schemed changed after the Tequila Crisis in 1994 when the defaults were high due to loans being in U.S. dollars. The loan was $\$ 23$ million dollars that was paid off and a new line of credit was taken out about US\$32 million dollars. At that time, the World Bank loan used Banobras as an intermediary, which had higher interest rates but used the conversion rates of dollars from 2005. ${ }^{59}$ With the Banobras loan, the state paid back its debt in Mexican pesos in 2007 at a 90 percent rate. In November 2008, the city started a new line of credit at two percent interest. According to one public official, the World Bank offered higher rates than the private sector. For example, the Banco de Bajío has lower rates, but at a short term. With these rates, the municipality has to abide by the law of how much it can take out in public loans. The city posts their reports on the Website to be transparent. ${ }^{60}$

Administrative capacity is high in Leon, so much so that their financiers can manipulate data and misplace public money on the capital markets. For example, one public administrator remarked, "public debt is not bad-it's just how you spend the money that counts. The problems most municipalities have are the quality and capacity of the work. The citizens own the bonds. Leon had three years of miss management by the

59 The Federal social program set up by Salinas distributed the first Ramo 26 in the old transfer system before Zedillo transformed the inter-governmental relations in 1997 (which was later developed into the Ramo 28 and 33). The funding to Guanajuato went towards the public transportation system. Of the city's budget, $\$ 3400$ million pesos are spent primarily on public transportation.

60 The city's Website (www.leon.gob.mx) posts its month budget but does not aggregate the numbers, they do not report numbers programmatically and thus cause significant difficultly for researching expenditure and revenue generation. Once a new city administration comes on board they typically delete their predecessors Web site so there is no historic data to review on how the city has projected its finances over time. 
mayor." Their public officials often had tradeoffs between the city and the state, and therefore, have quality people working at both levels of government.

\section{Leon's Local Economy}

The major industries in Leon include agriculture, tourism, and small industrial development. The city forms a major urban conglomeration with major center for truism, trade and commercial activities. While the city has been historically the country's largest leather and footwear producer, it is now diversifying its local economy. Table 7.11 describes the depth of the economy by showing the types of industries that Leon has and its strength in the general economy. Large manufacturing, commercial, and private financial services are major components of the local economy.

\begin{tabular}{|lllll|}
\hline 7.11 Leon's Economically Active Population by Sector \\
\hline Sector & $\begin{array}{l}\text { Personal } \\
\text { Employed }\end{array}$ & $\begin{array}{l}\text { Total Gross } \\
\text { Production } \\
\text { (million pesos) }\end{array}$ & $\begin{array}{l}\text { Total input } \\
\text { (million } \\
\text { pesos) }\end{array}$ & Gross Value Added \\
\hline Total & $\mathbf{2 4 1 , 3 0 2}$ & $\mathbf{3 7 , 2 0 3 , 6 8 5 . 6}$ & $\mathbf{2 0 , 7 4 3 , 7 7 0 . 4}$ & $\mathbf{1 6 , 4 5 9 , 9 1 5 . 2}$ \\
\hline Fishing & 24 & 207 & 10 & 197 \\
\hline Mining and Extraction Industries & 51 & $5,636.0$ & $3,821.0$ & $1,815.0$ \\
\hline Manufacturing & 103,397 & $19,437,983.0$ & $13,730,825.0$ & $5,707,158.0$ \\
\hline Construction & 8,017 & $1,309,793.0$ & $893,930.0$ & $415,863.0$ \\
\hline Commercial Operations & 62,960 & $8,307,884.0$ & $2,587,155.0$ & $5,720,729.0$ \\
\hline Transport and Communication & 15,562 & $3,162,750.6$ & $1,178,464.4$ & $1,984,286.2$ \\
\hline Private Services not Financial & 51,291 & $4,979,432.0$ & $2,349,565.0$ & $2,629,867.0$ \\
\hline Source: (INAFED Instituto para el Federalismo y el Desarrollo Municipal 2010) & \\
\hline
\end{tabular}

\section{Economic Development Efforts}

The current mayor has made an effort to promote economic develop within Leon. For example, in his 2009, Ricardo Sheffield administration reports his personal promise to finance over ten thousand SMEs through a micro-credit fund (Leon 2009). His annual report further highlighted that 2,645 citizens received training and 542 has received financial assistances for their small business. The city's program has promoted 956 
micro-credits for citizens to open new business within the community. The administration is trying to improve the speed with which businesses can open and so therefore they have created five new offices called Sistema de Apertura Rapida de Empresas (SARE). Additionally, city officials are working with the private sector to attract private investments. In 2009, the amount of private sector investments totaled US\$114,530,000 dollars and created more than 2,627 direct jobs (Leon 2009).

Additional efforts to promote the local economy include: providing free Internet services in nine of the major public plazas; restoring the historic area in time for Mexico's bicentennial celebration (September 16, 2010); the creation of three technology parks; creating a university center for research, strengthening the museum; increasing tourism to the area by improving attractions, improving the quality of the municipal golf course and promotion an international balloon fair. Finally, the city is working in conjunction with the state, which was assigned $\$ 36,750,000$ pesos to a program called "Mi Plaza," which conserved 5,000 jobs to improve the commercialization and production of cultural artifacts for the local economy (Leon 2009).

\subsection{Summary Discussion}

Overall, Zedillo's revenue decentralization policies, through the creation of Ramo 28 and Ramo 33, have increased the state's municipal programs. Cities have more financial resources allocated through the state government to implement supplementary programs, but no one municipality is autonomous. Tax effort has decreased throughout the same period. Although nearly every municipal treasurer stated that they have made serious efforts to collect more taxes or cut inefficiencies. The intergovernmental transfers (the revenue decentralization) have also come with more responsibility and a higher 
commitment for upward reporting, although not necessarily downward accountability to citizens.

For at least the past 20 years, city officials have been increasingly able to decide where their public investments should be made. The local officials within a specific municipality do not always decide where large state investments are allocated. State officials primarily evaluate the municipalities' finances and decide where the public projects that the national government wants to invest in (for example the highway projects around Leon). These decisions are made often times on political costs and not based on market decisions. Public investment decisions are more likely to be made from political costs, e.g. who will publicly benefitted in the next election cycle, rather than, what revenue the project would generate. For example, the investment decisions of investing in a Pemex refinery in Celaya under the Calderon government sought more political capital then high rates of return. ${ }^{61}$ As for rural development, the state is interested more in larger investment deals then building a producer small-scale economy. Many of the local officials seek solutions such as microcredit funds to deal with their large-scale problem of rural poverty. The state knows that it must take advantage of the rural sector to implement projects. For example, one public official cited that 50 percent of municipal highways improvements are made investments from the State.

The traditional responsibilities for municipalities, granted through the 1917 Constitution, have increased from trash pickup and improvements of water treatment plants to more demanding activities such as ecological programs and economic development promotion. Most public officials are involved in promoting LED activities,

61 Celaya, Guanajuato with a current Pemex refinery, was in direct competition with Michoacán, a state situated adjacently to Guanajuato and the home state of President Calderon, for infrastructure improvements. 
even if their cities do not have a formal tax or financial incentive program to do so. Typically municipalities are open in terms of sharing their financial and programmatic data and many leaders are engaged in developing an LED agenda to overall their city's wellbeing. The level of education and commitment to community development by public officials are high. Even with corruption taking place, the public official's knowledge of finances was commendable.

Whether public officials had undergraduate degrees or more advanced degrees (Masters, diplomas or other certifications), this research found that most local government officials sought to eliminate waste and promote new local programs within the constraints of their city budgets. With a few exceptions, local public officials were not open to express re-election reforms. The city of Leon is substantially more involved with local politicians into state and national leaders than its partners in San Miguel or Guanajuato City. This also is because it is the largest city in the state and has more population to identify possible new leaders. Of course the PAN influence was an influential factor for all policies throughout the State of Guanajuato. San Miguel has had more plurality, in terms of opposition parties, in their local council than Leon and Guanajuato.

This research found that civil society groups are active in Guanajuato. The city of San Miguel, in particular, sited to have the most active and aggressive demands from its local civil society groups. This could be from the increasing American expatriate community living there, which has created some animosity. Yet these foreign born residents did not seem to increase the municipal budget as substantially as previously expected. The increase in property taxes, which would be the most effective way to tax 
this population, seems to be a small portion of the overall budget. San Miguel had the highest amount of intergovernmental transfers than any other Mexican case study, most likely because it has the least amount of population and is perhaps more rural.

Arguably, if forgone property tax revenue systems were collected, this could also improve the quality of public services offer by the city. The increase of demand is not responded through the increase of supply of public goods. However, unfortunately, with the negative incentive to collect more revenue established by the national legal framework for municipalities, it is hard to assess the true costs of the property increased by the foreigners. According to one academic in Guanajuato:

Although the new Federal Revenue Sharing within Mexico, managed by the National Treasury did allow decision-making and authority of levels of taxes to be made at the local level, they lack teeth. Municipalities have the right to levy tax fees, business locations and permits, renting, "derechos" or rights, for general services such as water and light. They are not allowed the right to change property tax bases. The State governments are the last line of decisions for municipalities. The best position for a local government official is to lose a national election. In that way, they would be selected to be the next director of public works for their state team.

As such a new appointee can manipulate the state finances to benefit their political career for the next election cycle. This clearly illustrates the poor incentives that the political process has created within the intergovernmental system.

Still other research suggests there are more serious problems with the Mexican public administration (Merino Huerta 2008). Mayors are elected to serve three-year terms, "the first year is used to learn the system, the second to allocate public funds for personal benefit, and the third to discover ways to cover up the embezzlement." Another politician related this type of fraud could be worse, since often times the narcotraffickers 
often try to extort public officials into protecting the territories where they are producing, carrying, and selling illegal drugs.

Although the debate continues to surround the municipal election process, the immediate conclusion finds that reforms are necessary to improve the quality of life for Mexican residents. ${ }^{62}$ This research further finds that forgone local tax revenue from property could create larger budgets for cities. The capital city of Guanajuato was the only case that made an attempt to increase its revenues, which were used to promote economic development activities. The next chapter tests these assumptions and reevaluates the case study's data by using a comparative perspective.

\footnotetext{
62 As of June 2011, one PAN senator from Tijuana has sponsored a bill that would change election laws for Congress to re-elect mayors, senators and federal deputies. Currently the bill has not passed the divided Congress (the PRI controlled lower house) but will be reviewed again on the Congressional floor in the fall of 2011 before the PAN President Calderon leaves office.
} 


\section{CHAPTER VIII}

\section{ANALYSIS OF THE SIX CASE STUDIES}

\subsection{Introduction}

This chapter looks comparatively at the six case studies in order to better understand what factors influence a city's commitment to collect additional local tax revenue and promote economic development programs. The chapter focuses on the independent variables to determine what shapes cities' decision-making efforts. It pays particular attention to the city's political ideology, intergovernmental structure, geography, mayoral leadership, and the professional development of the staff in order to determine city's tax collection and spending priorities.

Evidence in this study shows that lack of coordination between a city's tax collection efforts and economic development investments. Even though it was assumed that tax collection in Mexico would be lower than in Argentina, because of their varying levels of commitments to national decentralization policy reforms, the city governments studied were only minimally affected. Additionally, the analysis shows that bigger cities do not necessarily collect more taxes and spend more on economic development programs. Furthermore, just as revenue collections are based on a complex set of issues, so too are expenditure decisions. A city’s administrative capacity has a greater impact on these policies than what was originally assumed. In general, the most important external factor for city government to make decisions is their political relations with higher-level public officials at the state or federal level of government. City governments in this 
analysis are more reliant on fiscal transfers from political relations of their subnational government than any other source. Nevertheless, the data collected in this chapter suggest that cities can be the economic development engines for the future if they so choose, and as such, Latin American cities can manage sound urban financial policies.

This chapter is broken down into the following sections. First, an overview of the six case study budgets is provided. The chapter provides an analysis of the tax authority and revenue trends (measured as tax revenues divided by GDP) for each of the selected governments. Next, a brief comparison of the six cities expenditure and revenue collection rates is provided. Finally, the chapter concludes by evaluating alternative hypothesis (variables evaluate included political ideology, intergovernmental structure, a city's geography, mayoral leadership, and the professional development of the municipality's staff) as a way to better understand the decision making-efforts of cities to collect more taxes and fund more economic development programs.

\subsection{Budget Analysis of the Six Cities}

It was found that there is a large variation between each city's per capita budgets. Cities in this study spend annually from US\$218 per person in San Miguel de Allende to as low as US\$80 per person in Santa Fe. This wide range could represent the impact of public policies at the local level. Although the six cases consist of large metropolitan areas, capital cities and smaller towns, it was found that neither population size, nor industrial strength were important factors for determining how much a city per capita. This provides a wide range of alternative factors to city's decision-making. Table 8.1 provides a synopsis of size and public finances for the six cities. 


\section{Table 8.1 Cities Population, GDP and Budget Size of the Case Studies in 2005}

\begin{tabular}{|l|l|l|l|l|l|}
\hline City & Population & GDP & $\begin{array}{l}\text { GDP Per } \\
\text { capita }\end{array}$ & Total Budget & $\begin{array}{l}\text { Total Budget } \\
\text { Per Capita* }\end{array}$ \\
\hline León & $1,436,480$ & $16,191,394,636$ & 12,668 & $180,800,000$ & 141 \\
\hline Guanajuato & 171,709 & $1,493,480,230$ & 9,738 & $24,982,000$ & 162 \\
\hline $\begin{array}{l}\text { San Miguel de } \\
\text { Allende }\end{array}$ & 160,383 & $1,065,245,712$ & 7,647 & $30,370,000$ & 218 \\
\hline & & & & & \\
\hline Rosario & $1,159,004$ & n/a & n/a & $155,000,000$ & 134 \\
\hline Santa Fe & 369,046 & n/a & n/a & $29,470,000$ & 80 \\
\hline Rafaela & 83,642 & n/a & n/a & $15,659,000$ & 187 \\
\hline Anfara & & &
\end{tabular}

All Values are calculated in US\$ Dollars (using an exchange rate for 2005). There is no GDP data for Argentina at the municipal level. * Calculated by diving the total budget by the total population in 2005 .

Table 8.2 demonstrates each city's authority to manage its public revenues. Ratings were established in chapter III based on the previous descriptions of authority for each of the subnational governments. Because of the federalist systems, provinces in Argentina and states in Mexico determine the legal authority in which local governments operate. In general, Argentine municipalities have more legal authority and discretion to tax. Argentina has more control over setting tax rates and debt capacity than their Mexican counterparts.

\begin{tabular}{|l|l|l|l|l|l|l|l|}
\hline Table 8.2 Revenue Generation Levels to Measure Authority* \\
\hline $\begin{array}{l}\text { Does the municipality have the } \\
\text { ability to increase taxes? }\end{array}$ & Yes & Yes & Yes & No & No & No \\
\hline $\begin{array}{l}\text { Does the municipality have the } \\
\text { ability to impose new taxes? }\end{array}$ & Yes & Yes & Yes & No & No & No \\
\hline $\begin{array}{l}\text { Does the municipality have the } \\
\text { capacity to issue bonds? }\end{array}$ & Yes & Yes & Yes & Yes & Yes & Yes \\
\hline $\begin{array}{l}\text { Does the municipality have the } \\
\text { capacity discretion to use trust } \\
\text { funds? }\end{array}$ & Yes & Yes & Yes & Yes & Yes & Yes \\
\hline $\begin{array}{l}\text { Does the municipality have the } \\
\text { ability to roll over funds? } \\
\text { *Estimates made from Interviews with Municipal authorities. }\end{array}$ & Yes & Yes & Yes & Yes & Yes & Yes \\
\hline
\end{tabular}

\section{Revenue Analysis}

As described in chapter $\mathrm{V}$, Argentine cities have more legal authority to encourage local taxation over their Mexican counterparts. Figure 8.1 uses data gathered 
from each of the case study cities to show trends from 1999-2008. Argentine cities Rosario and Rafaela have almost five times more own-source revenues (TOSR) than Leon and San Miguel de Allende, which is almost double in Guanajuato. The TOSR is measured as the total locally generated revenues, by inputs of local taxes (property, fees, and fines), and public debt minus inter-governmental transfers and international and philanthropic aid. For the city of Santa Fe, since the data is not always consistent overtime, the financial situation is difficult to determine. Accordingly, transfers influence the overall total budgets for Mexican cities. The exceptional case is Guanajuato, which has a high proportion of transfers and high TOSR, because of its incorporation of the museum, for which the city collects entrance fees.

Figure 8.1 Percentage TOSR for Six Cities in Argentina and Mexico

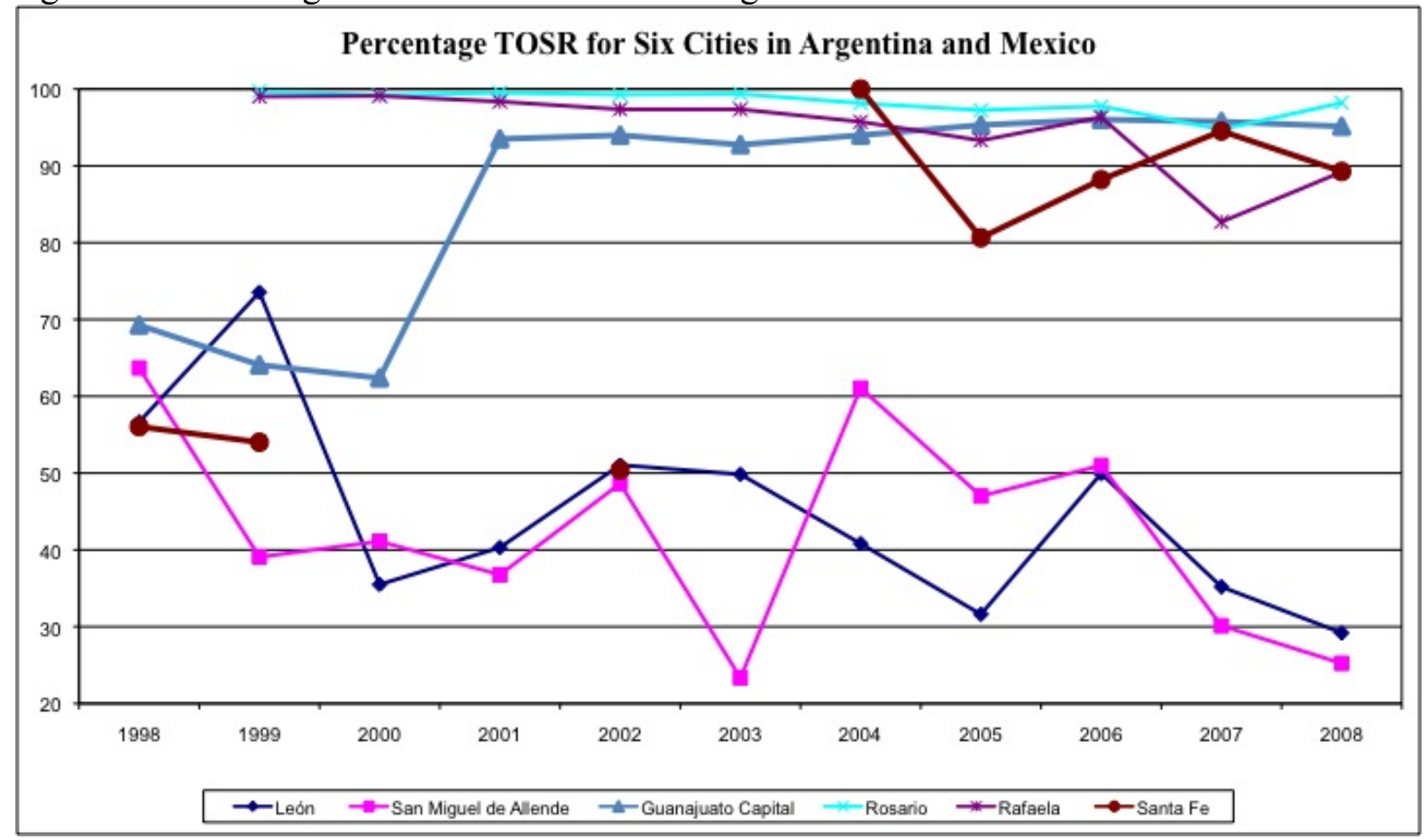

Source: INEGI, Mexico; Argentina City Treasuries

The data shown in figure 8.1 are consistent with the hypothesis that the cities, for different reasons, have varying degrees of autonomy and this either enables them to develop alternative sources of revenues or rely more on intergovernmental transfers. For 
example, the city of Guanajuato incorporated a national museum and charges entrances fees to pay for municipal development projects. San Miguel de Allende has a large expatriate community, which has a significant amount of outside philanthropic assistance which also supports the community. Santa Fe has used municipal bonds to plan and pay for its public works. Rosario has used a trust fund authorized by the national government in order to borrow funds to use for public works. Rafaela has strong political party ties to the national government and has developed a dependency on inter-governmental transfers for financing economic development programs. Leon redesigned its cadastre (the official register containing the municipalities land ownership information and property values) and re-designed its property tax system.

Table 8.3 illustrates the revenue compensation for each city. Argentine cities collect more local taxes than their Mexican counterparts. The largest Argentine city, Rosario has collected the most own-source revenues (TOSR), and to a lesser degree, Santa Fe, for where data is available. This is primarily because Rosario is one of the wealthiest cities in Argentina and provides tax revenues for the rest of the country. The most similar Mexican case is Guanajuato, which has also a high degree of TOSR, but the general trend in Mexico is to depend on intergovernmental transfers. This perhaps is due to the federal revenue decentralization which began in Mexico in 1997. However, in the cases studied here, the Argentine cities have larger TOSR compared with the Mexican cities, which is consistent with the different degrees of decentralization policies at the national level, particularly as regards to revenue matters. 
Table 8.3 Revenue Composition of Annual City Budgets (in percent, per items)

\begin{tabular}{|c|c|c|c|c|c|c|c|c|c|c|}
\hline \multicolumn{11}{|c|}{ Revenue composition } \\
\hline & 1999 & 2000 & 2001 & 2002 & 2003 & 2004 & 2005 & 2006 & 2007 & 2008 \\
\hline \multicolumn{11}{|c|}{ Ros ario Total } \\
\hline Transfers & 0 & 1 & 0 & 1 & 1 & 2 & 3 & 2 & 5 & 2 \\
\hline TOSR & 100 & 99 & 100 & 99 & 99 & 98 & 97 & 98 & 95 & 98 \\
\hline \multicolumn{11}{|c|}{ Rafaela Total } \\
\hline Transfers & 36 & 33 & 30 & 32 & 33 & 32 & 32 & 31 & 27 & 29 \\
\hline TOSR & 64 & 67 & 70 & 68 & 67 & 68 & 68 & 69 & 73 & 71 \\
\hline \multicolumn{11}{|c|}{ Santa Fe Total } \\
\hline Transfers & 46 & $1 / \mathrm{a}$ & $\mathrm{n} / \mathrm{a}$ & 501 & $\mathrm{n} / \mathrm{a}$ & 0 & 19 & 12 & 5 & 11 \\
\hline TOSR & 54 & $1 / \mathrm{a}$ & $\mathrm{n} / \mathrm{a}$ & 501 & $n / a$ & 100 & 81 & 88 & 95 & 89 \\
\hline \multicolumn{11}{|l|}{ León Total } \\
\hline Transfers & 26 & 65 & 60 & 49 & 50 & 59 & 68 & 50 & 65 & 71 \\
\hline TOSR & 74 & 35 & 40 & 51 & 50 & 41 & 32 & 50 & 35 & 29 \\
\hline \multicolumn{11}{|c|}{ San Miguel de Allende Total } \\
\hline Transfers & 61 & 59 & 63 & 51 & 77 & 39 & 53 & 49 & 70 & 75 \\
\hline TOSR & 39 & 41 & 37 & 49 & 23 & 61 & 47 & 51 & 30 & 25 \\
\hline \multicolumn{11}{|c|}{ Guanajuato Capital Total } \\
\hline Transfers & 36 & 38 & 7 & 6 & 7 & 6 & 5 & 4 & 4 & 5 \\
\hline TOSR & 64 & 62 & 93 & 94 & 93 & 94 & 95 & 96 & 96 & 95 \\
\hline
\end{tabular}

Expenditure Analysis

Next, an expenditure composition is analyzed. Argentine cities show a similar trend with respect to public employees' wages (listed as wage bill). They all devote a large amount of resources to finance their public employees. Santa Fe, as the capital of the province, has the highest amount of expenditure for public employees (wage bill average 59 percent). This is followed by Rafaela ( 37 percent), the smallest city analyzed in Argentina, has the lowest expenditures for employee's wages. Rosario, a big city with a strong private sector devotes almost half of its expenditures (48 percent) to pay public employees. This number might be explained because smaller cities need smaller bureaucracies, and capital cities, with a bigger public sector (for management and administration) may need to have a more costly bureaucracies. Cities with a stronger private sector spend less in financing public employment (as is the case of Rosario). 


\begin{tabular}{|c|c|c|c|c|c|c|c|c|c|c|}
\hline & 2000 & 2001 & 2002 & 2003 & 2004 & 2005 & 2006 & 2007 & 2008 & Average \\
\hline \multicolumn{11}{|l|}{ Rosario } \\
\hline Wage Bill & 52 & 53 & 49 & 44 & 44 & 45 & 45 & 48 & 51 & 48 \\
\hline Public Works & 12 & 17 & 8 & 12 & 16 & 24 & 20 & 15 & 6 & 16 \\
\hline Other & 36 & 30 & 43 & 44 & 40 & 31 & 36 & 37 & 42 & 36 \\
\hline \multicolumn{11}{|l|}{ Rafaela } \\
\hline Wage Bill & 40 & 43 & 43 & 34 & 37 & 34 & 33 & 31 & 34 & 37 \\
\hline Public Works & 2 & 2 & 4 & 4 & 4 & 3 & 3 & 3 & 2 & 3 \\
\hline Other & 58 & 55 & 53 & 62 & 59 & 63 & 64 & 66 & 64 & 60 \\
\hline \multicolumn{11}{|l|}{ Santa Fe ${ }^{63}$} \\
\hline Wage Bill & $\mathrm{n} / \mathrm{a}$ & $\mathrm{n} / \mathrm{a}$ & 78 & $\mathrm{n} / \mathrm{a}$ & 64 & 50 & 52 & 40 & 62 & 59 \\
\hline Public Works & $\mathrm{n} / \mathrm{a}$ & $\mathrm{n} / \mathrm{a}$ & 2 & $\mathrm{n} / \mathrm{a}$ & 7 & 15 & 11 & 18 & 3 & 9 \\
\hline Other & $\mathrm{n} / \mathrm{a}$ & $\mathrm{n} / \mathrm{a}$ & 19 & $\mathrm{n} / \mathrm{a}$ & 30 & 36 & 37 & 42 & 35 & 32 \\
\hline \multicolumn{11}{|l|}{ Leon } \\
\hline Wage Bill & 31 & 27 & 30 & 33 & 38 & 33 & 36 & 38 & 32 & 32 \\
\hline Public Works & 0 & 0 & 0 & 0 & 0 & 0 & 0 & 0 & 0 & 1 \\
\hline Other & 69 & 73 & 70 & 67 & 62 & 67 & 64 & 62 & 68 & 67 \\
\hline \multicolumn{11}{|l|}{ San Miguel } \\
\hline Wage Bill & 20 & 25 & 17 & 23 & 22 & 18 & 18 & 24 & 16 & 20 \\
\hline Public Works & 45 & 21 & 44 & 35 & 22 & 50 & 61 & 51 & 39 & 40 \\
\hline Other & 35 & 54 & 39 & 42 & 55 & 32 & 21 & 25 & 45 & 39 \\
\hline \multicolumn{11}{|c|}{ Guanajuato Capital } \\
\hline Wage Bill & 40 & 45 & 37 & 39 & 34 & 37 & 47 & 48 & 45 & 41 \\
\hline Public Works & 30 & 13 & 13 & 43 & 43 & 42 & 21 & 14 & 12 & 24 \\
\hline Other & 30 & 42 & 49 & 18 & 23 & 20 & 32 & 38 & 44 & 35 \\
\hline
\end{tabular}

The above analysis also holds for the Mexican cities. This may be because in Mexico, cities pay lower salaries have few employees or they get more project related funding from transfer funds. Guanajuato spends a higher amount of its resources to pay public employees' wages (41 percent). Leon a city with a large private sector spends less (32 percent), and finally, San Miguel the smallest city does not allocate many resources to finance their public employees (20 percent). While Leon provides almost nothing for their public works, San Miguel and Guanajuato spend a higher percentage of their resources for public works. The differences between cities in both countries with respect to public works might be explained by the presence of the federal government transfers,

63 The full version of these values is in the Annex 5. Santa Fe's data is not reliable. 
which invests in bigger cities (Leon) and is less present in medium (Guanajuato) or small cities (San Miguel de Allende).

Guanajuato's uniqueness in collecting local revenue might be explained by the fact that it is the capital of the state and has strong investments in operating capital expenditures. The infrastructure funds (Ramo 33) provided by the federal or state governments explain this for the Mexican cases. The federal government, for example, also provides funds for education and health. Either the state or federal government can finance public works investments. Mexican cities depend considerably more on federal grants than their Argentine peers because of differing degrees of national decentralization. Additionally, Mexico's low proportion of wage bill expenditures reflects the possible bias towards the receipt of federal funding. Argentine cities might devote more resources for wage bill because they rely less on national transfers.

Figure 8.2 Percentage of Public Works Expenditures in Six Cities in Argentina and Mexico

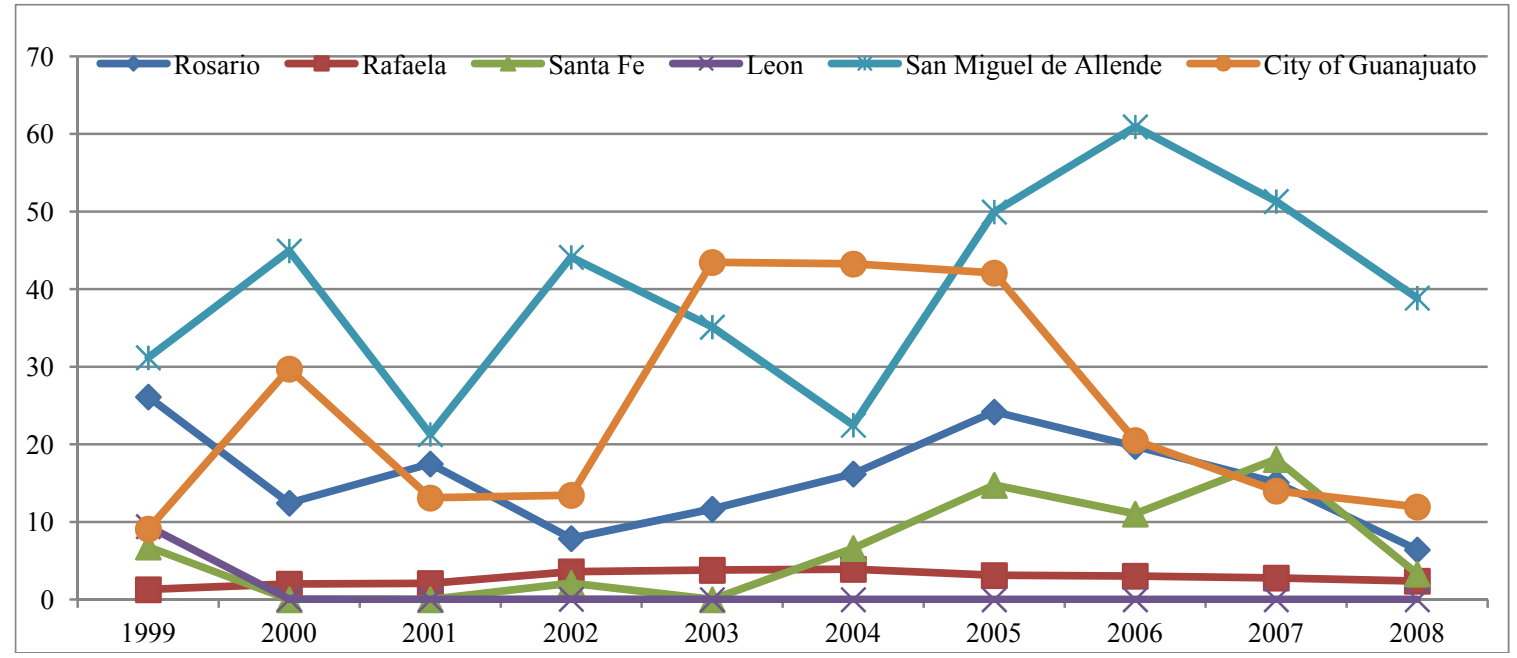

Source: INEGI, Mexico; Argentina City Treasuries

In general, Rafaela, Rosario, and Guanajuato were perceived to have higher amounts of local own-source revenues and spend more on public works. As shown by the data gathered in figure 8.2, this hypothesis is correct. San Miguel de Allende, Leon, and 
to some extent Santa Fe, are more dependent on the national government transfers to pay for public works in their communities. An increase in local own-source revenues may result in higher public works expenditures as in the case of Santa Fe, but this is not the true for all of the cases. Leon should be discarded for this analysis due to the fact that there could be "hidden" federal investments in public works. For example, the financial help from the federal government discourages Leon from investing its own resources into public works.

Rosario is an exceptional case of autonomy from the Argentina's federal government. The city has almost 100 percent TOSR and it also invests a majority of it revenues locally. Rosario is also one of the wealthiest cities in Argentina and contributes much of its revenues to other levels of the federation. This means that - as in the Leon case-federal investment is not behind such a robust effort as it is also a contributor to national policies. Rosario spends less on public works from its local tax collection efforts. Rafaela is the average case in Argentina with a sizeable collection of local tax revenues, but lower amounts of public works expenditures and high percentage of expenditure toward public employees. From this description, federal issues may affect city finance more in Mexico than Argentina.

Finally, figure 8.3 shows the GDP per capita measured in U.S. dollars for each of the subnational governments from 1992-2008. ${ }^{64}$ Data is not available to do this at the municipal level. Whereas Guanajuato has a population of almost five million, its

\footnotetext{
64 The method for the "GDP (USD Dollars)" chart was calculated by using current pesos for each country divided by the exchange rate for each year [note that this chart is more "real" in the way that incorporates the inflationary effect of the exchange rate problems faced by Mexico from 1994-95. While inflation is low in Mexico from 2000 onwards the opposite can be noted in Argentina, where the 2001 crisis had a 100 percent devaluation of the Argentine peso, again with important consequences for inflation]. The chart "GDP per capita Guanajuato (Mexican pesos, base year 1993) was included since the data was already calculated by INEGI, yet using 1993 as a base year.
} 
economic growth has increased steadily in the past 20 years. In contrast, Santa Fe has a population with just over three million people and its GDP has fluctuated from US\$7,000 per person in 1994 to US\$2,000 in 2000, only to grow to US\$7,000 per person in 2008 .

Figure 8.3 Subnational GDP Compared Guanajuato and Santa Fe 1993-2008

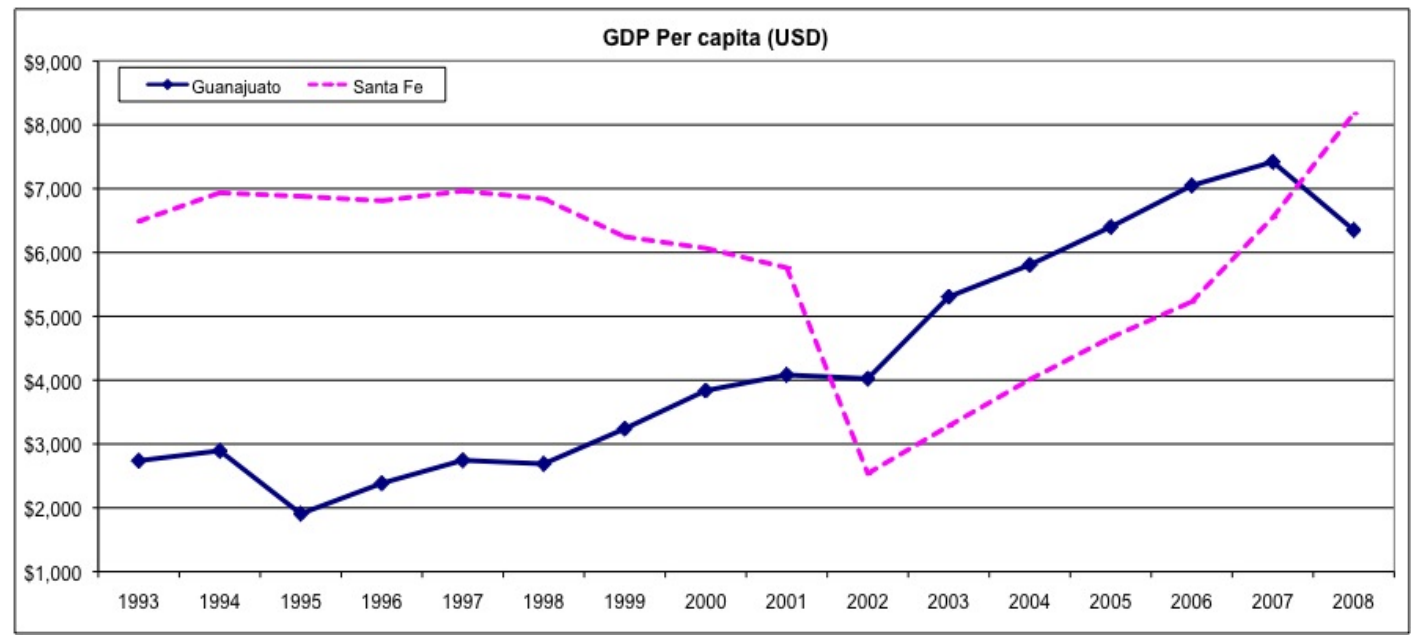

Source Guanajuato: INEGI Dirección General de Estadísticas Económicas. Santa Fe: IPEC, Provincia de Santa Fe, 1993-2008.

This figure shows that the national economy has major influences on the subnational governments' budgets and GDP. For example, Mexico experienced a major devaluation in its currency after the Tequila Crisis in 1994 and also was hit hard by the United States most recent economic slowdown beginning in December 2007. Argentina suffered an economic recession beginning in 1998 and ending with the financial crisis of 2001, when unemployment escalated 25 percent, the peso devalued and the government defaulted on its international loans. These larger economic shocks have affected the subnational economies a great deal as well as their efforts at local economic development. A city's local investments have little influence on the overall state of their macro-level economies, but rather they are more dependent on the national management of the economies than originally perceived. 


\section{Tentative Conclusions}

After evaluating and comparing the six city budgets, it was found that there were large variations between the cities' per capita expenditures for both countries, even after controlling for size and the industrial development of the cities. Since Mexico's national tax collections are a lower percentage of GDP than their Argentine counterparts, it would be expected that they also have lower local collection rates. This was found not to always be true. Another assumption was that bigger cities collect more taxes per capita because they have a larger population to collect from, but they do not. Also, the cities in this analysis have differing reasons for why they collect more local own source revenue and also for which types of programs they spend these extra funds. Some spend more on wage bill, while others on capital improvements and the amount for economic development varies a great deal due to the amounts of current development in the region. This study finds that the expenditure and revenue decisions for the case study cities are not correlated with the degree of decentralization or centralization by the national governments. Therefore, the next section looks at other alternative variables, which could help explain these differences.

\subsection{Other Independent Variables}

There may be several other factors, which could result in local governments to modify their spending and tax collection efforts. Alternative hypotheses for these responsibilities may include: political ideology, inter-governmental relations, geography (i.e. history and cultural legacy), mayoral leadership, and the professional development (i.e. educational levels) of the public employees. Therefore the following section describes each of these variables. 


\section{Inter-governmental relations}

This study finds that inter-governmental relations between members of the same party at different levels of the bureaucracy is the most important factor for local government officials to increase public finances to their local community and establish more successful economic development programs. The variable for inter-governmental relations seeks to analyze the relationship between the local political leadership with the hierarchy of governmental officials. The inter-governmental relationship variable could be for individuals in the same political party or in different political party, but most relevant for this study is the relationship of individuals who have government positions in higher-level offices. It seeks to not understand the involvement of the local government leaders to their national political parties. But rather, it is the involvement that a city official has with higher-level government officials and his or her ability to bring additional finances back to the local community and establish more successful economic development programs.

In Argentina, the leadership for the city of Rosario is from the same political party as the province and has socialist origins. The city of Rafaela's leadership is from the Partido Justicialista (PJ) party, which is the same as President Kirchner. The city of Santa Fe currently has a mayor who formed a coalition from the left socialist party and the right Union Civicia Radical (UCR) party. Several public officials in Rafaela were concerned about the conflict that exists between the PJ and socialist party. City officials felt that several public works projects would not be finished or not have sufficient financing to accomplish their goals. In particular, the highway projects and the water and sewage upgrades within the city were contingent on provincial funds. The mayor has sought 
assistance from the Federal government for these projects, who are members from his PJ party. For Rosario, the city government has the same political leadership as the governor (who actually was previously the mayor of Rosario) and therefore shares political ideology, finances and municipal personnel. Because of the transfer system of the coparticipation laws in Argentina, Rosario's economy is one of the biggest generators of public resources for the province and therefore is responsible for managing the economy as a whole. The shared sense of commitment by the government between the city and the governor's office to the province of Santa Fe can be identified by the policies that each has to promote more sustainable development with high investments in human capital with its education and healthcare activities.

In Mexico, the government of the state of Guanajuato has benefited from the leadership of Vicente Fox as president and leader of the National Action Party (PAN) political party, both at the state level but also at the national level. The cities of Guanajuato, Leon, and to some extent, San Miguel de Allende, have a majority PAN leadership, which aligns them politically away from the former the PRI and have majorities in the state congress and the presidency. The state politics changed after the PAN defeated of PRI, which had dominated Mexico's political life for over 70 years. The finances for each of the cities studied have directly benefited from the political leadership in the Presidential palace, Los Pinos. These benefits are tangible through the funding of public programs and political careers. For which several interviewee had represented the city government at some capacity, then the state and later the national government and may have returned back to work at the local municipality but at a different job. Several of these public administrators had been promoted to higher political offices because of the 
PAN political party, including President Vicente Fox himself. Therefore this variable of inter-government political relations is highly relevant and a major factor of how local administrators manage their public programs at the local and state levels.

\section{Political ideology}

Although different than the inter-governmental relations, the political ideology represents the analysis of whether ideology of the political leadership matters for its decision to promote more economic development and collect more tax locally. The policies in these case studies suggest that the political ideology does not matter as much as the political relationship that the local government has with his hierarchy within the same party (i.e. inter-governmental political relations). For example, in Argentina, Governor Binner began to promote his socialist agenda of strengthening the local environment by promoting more welfare policies of education and health care first in Rosario and then for the province. He started small as the mayor of a city and then ran for governor. In 2011, he also ran for president against President Kirchner but lost. In Mexico, the dominant political force for Guanajuato is the right conservative probusiness management of the state affairs. The government has promoted the increase of manufacturing from foreign entities and has encouraged investments in the private sector.

Yet, even with these extreme ideological debates on how to run a government, the cities in the case studies do not increase their efforts to tax or promote more local economic development programs. Rather each of the cities sought to find business niches and promote their local economy as the public officials could. The city of Guanajuato, for example, generates greater local own-source revenue by managing the national mummy museum, which thereby enabled the city to promote beatification programs in order to 
attract more tourism. Similarly, the city of Leon redeveloped its cadastres in order to encourage more local own-source revenue. Leon uses these funds to promote SME trainings and capacity programs to create and strengthen local enterprises. The city of Rafaela established an industrial park to attract business investments and the city of Rosario established a municipal bank to finance micro-credit loans to SMEs. The efforts to promote businesses and encourage local economic development are not necessarily correlated to the amount of resources collected at the local level, and not necessarily related to the political ideology of the current municipal government.

Geography (i.e. history and cultural legacy)

The representatives of the cities in the study devoted much time to explaining the cultural and historical references to why their individual locations, people and societies were important for the economic development in the region. Whether it was the Piemontes in Rafaela or the Sinarquistas in Guanajuato, the cultural legacy of the communities unifies and directly affects their own development process. The geography was one of the major indicators for the cities in the case studies to promote more economic development programs and collect more local own-source revenue. This was a positive and significant variable for each of the cities.

Furthermore, the efforts to development and advertise the cities from where the public administrators came from the physical environment to strengthen their cultural heritages. For example, the city of Santa $\mathrm{Fe}$ is known for the city where most constitutions were written and the city of San Miguel de Allende for the birthplace of the Mexican revolution against Spain. Additionally, the cultural heritage of each location helps strengthen tourism. 


\section{Mayoral leadership}

For the most part, each city in this study had strong mayoral leaders, which were well educated and professional in their decisions-making capacities. Whereas the Progressive era that transformed municipalities to be more management focused in the United States has not reached Mexico, the Mexican municipal governmental system is based upon a strong local leader. The non-reelection rule for the mayors has created a difficult for Mexican municipalities to continue their public policies. The budget and the decisions to spend and collect revenue are based first and foremost on the previous year's expenditure and collections and highly centralized by the mayor and the municipal treasurer. Each year the budget is presented and must be approved by the municipal council, which are elected positions. The mayor typically has major authority to authorize expenditures and develop municipal plans. Yet, the elected official is highly dependent on hierarchy of his party in order to be selected for future positions.

In Argentina, the mayoral leadership was strongest in Rafaela were Perotti had been leader for nearly 20 years. Also the governor Binner began his political career as the mayor of Rosario. The role for a strong leader is essential for the continuation of public policies. The leadership and education of the mayors in Argentina were higher than expected. For example, Binner was a medical doctor before going into politics and Perotti a professional accountant. The high levels of education represent a high level of accountability and commitment of these politicians to stay local and build their local communities. Whereas in Mexico, the mayor of one city might become mayor of another, or councilperson and then state representative, the political careers of the mayors in Argentina, who stayed more consistently local to their place of origin. 


\section{Public employee's professional development}

In general, the qualifications for the public employees were much higher than expected. Most public employees had university degrees and some had additional post graduate skills. In addition, many taught courses at the local university. Nearly all of the treasury officials had studied accounting and were registered accountants. Public officials had even completed postgraduate studies in the United States. The rate of education matched their professional level of work. Each official allowed sufficient time for interviews and brought a new perspective to the questions related to fiscal decentralization and economic growth. Many public officials had experience working in other large bureaucracies.

For example in Rosario, the municipal government lost many of its qualified public employees when the mayor was elected as governor. They moved to higher positions in the provincial government. The city has many students from the local university who helped run political campaigns who are public employees. Additionally, in Guanajuato, public employees worked in the state and the city governments and were very familiar with the work of others within the state government. Contacts were shared and relationships between levels of the bureaucracy were left open. This high level of spirit de corp exhibited among all of the six cases.

Finally, the following table describes the importance of the impendent variables for city officials to make decisions related to strengthening economic development within their municipalities. The variables are evaluated in a likart scale (1-3), which is measured as 3 being high to 1 being low. The information is reported on by the various interviews and perception given. 


\begin{tabular}{|l|l|l|l|l|l|l|}
\hline Table 8.5 Other Factors Affecting Local Development Decisions \\
\hline & Rosario & Rafaela & Santa Fe & Leon & San Miguel & Guanajuato \\
\hline $\begin{array}{l}\text { Political } \\
\text { Ideology }\end{array}$ & 1 & 1 & 1 & 1 & 1 & 1 \\
\hline $\begin{array}{l}\text { Inter- } \\
\text { governmental } \\
\text { Relations }\end{array}$ & 3 & 3 & 3 & 3 & 3 & 3 \\
\hline Geography & 3 & 3 & 3 & 3 & 3 & 3 \\
\hline $\begin{array}{l}\text { Mayoral } \\
\text { Leadership }\end{array}$ & 2 & 3 & 1 & 2 & 2 & 3 \\
\hline $\begin{array}{l}\text { Professional } \\
\text { Development } \\
\text { Employees }\end{array}$ & 3 & 3 & 1 & 2 & 2 & 3 \\
\hline$*$ Estimates made from Interviews with Municipal authorities. & & & \\
\hline
\end{tabular}




\subsection{Summary Discussion}

This chapter has demonstrated that local governments in Mexico and Argentina can manage their local resources, for example they can make complex finance decisions about their budgets. The public officials of each municipality know the needs of their communities. This study found that each city's spending decisions are based on very different independent variables. Particularly, it was the inter-governmental relations that provided to be the most influential factor for how local government officials made expenditure and revenue decisions. Other influential variables include the professional development, the role of the city mayor or the dependency on inter-governmental transfers and grants. This study, however, found that municipal treasurers had higher levels of professional development or levels of education) then what was expected. The local politics was the most important factor for economic development to occur within a municipality. More fundamental than left or right based political ideology, the basic political situation and the relationship between the local, state and national government seemed to be the most dominate factor in this.

Overall, the role of local politics and decisions by politicians is better understood. Nevertheless, funding decisions for projects were more often based on intergovernmental relationships, such as the personal politics of a city mayor within his or her party or with the president. For example, if a city has state funding to pave a road, then the municipality will hire more personnel to provide other public services. Yet, the most influential variable in all the cases are the political exchanges that the city's administrators have with the state level bureaucracies. More information and raw data are also needed to validate and comparative best if the total autonomous cities or regions can 
be agents of growth. Therefore, the next chapter tests these results by using a large data set from Mexico. 


\section{CHAPTER IX}

\section{MEXICO'S LOCAL FISCAL CAPACITY FOR ECONOMIC GROWTH: A QUANTITATIVE MODEL OF FISCAL AUTONOMY}

\subsection{Introduction}

In this chapter, the relationship between fiscal decentralization and economic development is further tested. The results from the qualitative case studies have shown that this relationship is tenuous at best. Investments in infrastructure or SME programs may be influential to improve a local economy, but they may not be sufficiently influential to drive the economic growth for an entire regional area. The qualitative cases suggest that a city needs to first have some degree of economic development in order to encourage tax collection at the local level. The likelihood of local administrators to first collect additional taxes and spend them on economic development programs is more likely if they see a positive political outcome first for their community or personal gain for themselves professionally. Although, if a local administrator is able to persuade the national or state government to finance a project such as building a community road, then they will more likely use the forgone expenses to hire more workers or provide other local public services that will build more political capital for them at a later point.

The qualitative research presented here also found that the amount of funds that a city devotes to economic development programs is relatively small compared to the total budget. A few thousand dollars a year and a handful of dedicated employees may not bring millions of dollars into a local economy. Rather, a city's wealth is more important for its ability to collect taxes and to bring business investment into the community. In 
essence, a city's wealth is the precursor for local tax collection. Thus, larger local budgets generally have more money to spend on local economic development programming.

This chapter draws upon this knowledge to hypothesize and perform a large-scale $\mathrm{N}$ regression to test whether more own source revenue (local tax collection) produces more economic development actually. First, this chapter provides an overview of the writing on Mexico's intergovernmental transfers system and describes recent research on forgone tax collection at the local level. This is an endogeneity problem (which comes first) is addressed. It is found that cities' first need to have some degree of economic development before they are able to collect more taxes locally. Next, this chapter uses a statistical model to evaluate quantitatively the relation of fiscal capacity to a city's investments in economic development programs. This chapter then explains these outcomes and the result of the endogeneity problem. By analyzing Mexico's municipal data, this chapter tests the efforts of innovative public finances on economic development.

\subsection{Evaluations of Mexican Fiscal Decentralization}

As a major global federation with a multifaceted history of centralization and recent democratization and decentralization starting in 1983, Mexico provides to be good case for the statistical analysis of fiscal decentralization (Diaz-Cayeros 2006). Not only because of its recent political upheaval and transition from a one party centralized controlled government and transformation into a multi-layered democracy where competitive elections now take place at the national, state, and local levels. Mexico also reformed its legal framework in 1997 to provide subnational financing and borrowing at 
the state and local level. As a developing country, Mexico provides an interestingly example for other countries to follow.

Even as Mexico has become more democratized, many academics have acknowledged that there are several problems in the intergovernmental system (Cabrero 2000; Cabrero and Carrera 2002; Hernandez-Trillo and Jarillo-Rabling 2002; HernandezTrillo and Jarillo-Rabling 2008; Raich 2002; Tamayo-Flores and Hernández-Trillo 2006). For example, research (Moreno 2004; Sour 2004; Sour 2008) has suggested that the transfer funds created since 1998 have reduced the incentives of local governments to collect taxes, particularly property taxes, as the most important tax revenue source for municipal governments.

In his work, Gamboa (1999) shows how the Mexican revenue-sharing may discourage revenue mobilization at the local level by increasing local government's dependency on central government transfers (Ramo 33 and 28). This is because these transfers decrease incentives of local jurisdictions to increase local taxes. Gamboa claims that, as in other federations, linking local revenues to service delivery costs improves governance in countries. This is because when the central government loosens control over subnational finances, local governments can enjoy financial autonomy and provide a more efficient use of revenues for public services (Gamboa in Fukasaku and de Mello 1999). This becomes a problem for local revenue collection as it becomes easier to request political favors from higher levels of government than for mayors and local authorities to raise taxes at the local level, which may be politically unpopular.

In her research on Mexico's federal transfer systems, Sour (2004) found that both non-conditional and conditional transfers (Ramos 29 and 33) have negative impact on all 
local governments tax collection effort. Although Sour states that she is measuring tax effort, she is actually measuring municipal tax capacity. ${ }^{65}$ In her study, she determines that there is no difference in fiscal performance by municipal size, but rather the larger and smaller municipalities are equally affected by the increase in federal aid received each year by the Mexican transfer system.

Cabrera Castellanos and Cruz Mora re-evaluate Sour's work by looking at the tax base and other revenues that a municipality can collect (Cabrera Castellanos and Cruz Mora 2009). They measure fiscal capacity by dividing municipal income into two components: the tax base by property tax, and "other" revenues. Consistent with Sour's work, these authors find that Mexican municipalities have a greater fiscal capacity that is currently not being exercised. Municipal governments have a wider tax based, which is not currently being utilized. In sum, there are more local resources that could be taxed. Also Cabrera Castellanos and Cruz Mora find that municipalities, which have more economic activity such as those with tourist destinations, are likely to collect more local tax revenues than less developed ones. These authors thereby conclude that industrial

65 "Fiscal capacity" is actual amount of total taxes a local government can collect, while "fiscal effort" is the power to raise funds over what is actually collected. Economists typically use the latter, which is an estimated value of actually property within an area of the city. Although Sour uses the municipal GDP variable, she does not give in detail the amount of funds that is not collected. The equation used by Sour (2004) is as follows:

$$
\begin{array}{ll}
\text { ingpop } & \text { part }+ \text { transf }+E \\
\text { pibmuni } & \text { imu imu }
\end{array}
$$

Part stands for participaciones (Ramo 26) the required amount automatically transfers from the national government to subnational authorities for being part of the Mexican federation. Transf stands for transferencias (Ramo 33) which are transfers from the federal government to subnational authorities for infrastructure projects. Each of these transfers has restricted and non-restricted portions and each state government can divide its funds as it wishes. Although most use a parity of the Federation's assessment for distribution, taking into account the size and economic development of the local community. Pibmuni is the GDP for each municipality and ingpop is the income per capita in order to create the level of economic development for each individual at the local level. Therefore she is actually using the equation for fiscal capacity and not effort. Sour realized this mistake and corrects in for a paper redone in 2008. 
activities of municipalities do have a bias for increasing the tax base for a local government.

\subsection{A New Approach and Data Analysis}

Most statistical studies use either "tax autonomy," "tax capacity" or "tax effort" as the dependent variable. Each of these topics is similar but do not have identical definitions. For most studies within the United States, both tax capacity and tax efforts are often measured with indicators constructed by the Advisory Commission on Intergovernmental Relations (ACIR). Tax capacity can be defined as the "capacity of a governmental entity to finances its public services" and tax effort can be understood as "the extent to which a governmental entity uses its tax capacity to collect more revenue" (ACIR 1990:13).

Within Latin America, Melo (2007) defined tax effort by calculating "the difference between the predicted [tax collection] and actual tax ratio." His work suggests that because Argentina has high per capita income levels - considerably higher than those of its counterparts in Latin America - the predicted tax level should be much higher than those observed in the last decades in the region, particularly in Brazil, Uruguay, and Chile, but he finds the opposite effect. These arguments are substantiated by the data on municipal taxation derived from the different sources or items that describe taxation. If the dependent variable (taxation) affects these indicators it demonstrates that taxation capacity modifies (a) the expenditure composition and it does so by building a more "friendly" context for economic outputs, (b) taxation also serves to build other types of institutional resources (financial, human, material) that serve to build policies which are 
friendlier to economic output, or, (c) the correlation helps with better rates of socioeconomic welfare.

This research diverges from the previous studies done by using as the dependent variable municipal GDP. The principal independent variable is total own-source revenue (TOSR). This is defined as a percentage of all local tax collection, which is calculated as property taxes, fees, fines, user charges and other local income sources minus state and national transfers (ramo 28 and 33) and any other philanthropic donations over total revenue. The expected result is a positive correlation between municipal government tax capacity or local autonomy and GDP.

\subsection{Statistical Techniques and Results}

A formal linear regression is used to test the model. The first test uses indexes developed by the INAFED called the Index of Basic Municipal Development (IDMD) or Indice de Desarrollo Municipal Basico, in Spanish. ${ }^{66}$ The database reports on municipal social, economic, environmental services and institutional development. Several variables are indexed to provide a full picture of municipalities in Mexico. Of importance here are the following variables: economic development (eco), institutional development (inst), and controls for the social dimension (soc) or the percentage of the population that finished primary school and enviormental factors $(a m b)$ which include housing with access to drainage, water, etc. The model looks like this:

\section{Model 1. IDB (eco) $=(a 1+a 2 \operatorname{soc}+b 3$ inst $+b 4 a m b)$}

\footnotetext{
66 The federal agency, which researches municipal development, the INAFED (Instituto Nacional para el Federalismo y el Desarrollo Municipal) contracted Dr. Laura Flamand of the Colegio of Mexico and her colleagues at the Colegio de la Frontera Norte, Sara Martinez Pellegrini and Alberto Hernandez, to develop this large database of municipal statistics.
} 
The economic development variable includes two dimensions. The first is the value added per capita at the municipal level. That is the increase of value that is added to a product on the commercial production line. The second includes the level of employment at the municipal level. That indicator captures the municipal economy by including employment and the amount of production within the municipality. The institutional development variable includes tax effort to demonstrate government financial performance and participation in elections as a reflection of society involvement in municipal affairs. The social dimension includes indicators that represent opportunities to acquire basic level of health and educational achievement, respectively: the proportion of population aged 15 and older who complete primary education or have post-primary and infant mortality.

\begin{tabular}{|l|l|}
\hline Figure 9.1 Regression Analysis using IDMB \\
\hline $\begin{array}{l}\text { Results of Economic Development on Institutional Strength using IDMB data from 2,454 } \\
\text { municipalities in Mexico }\end{array}$ \\
\hline Regressor: Dependent Variable Economic Value added per Capita (2005) \\
\hline SOC Social indicators & $\begin{array}{l}.034^{* * *} \\
(.005)\end{array}$ \\
\hline INST (institutional indicators) & $.008^{* *}$ \\
& $(.002)$ \\
\hline AMB (access to a swage system and other & $.005^{* *}$ \\
basic services indicator) & $(.002)$ \\
\hline ECO (employment indicators) & $-.483^{* *}$ \\
& $(.004)$ \\
\hline Regressor: Dependent Variable Economic Value added per Capita (1990) \\
\hline R2 & .898 \\
\hline N & 2418 \\
\hline The Regression was Estimated using the Mexican Case from 2005 data in the Indice de \\
Desarrollo Municipal Basico (IDMB) \\
\hline
\end{tabular}


The results show that economic development is positively correlated with institutional development (at the 95 percent confidence interval). Better tax effort and more participation in local elections will increase economic development and employment prospects within a municipality. Municipalities that encourage taxation and citizen participation are more likely to be economically developed. Additionally, social development is correlated with economic development. Higher education levels, health standards, and houses with drainage, are positively correlated with economic development. The employment index negatively correlates, which could mean that there is autocorrelation or a misspecification in the model. That is because it is assumed that if the GDP increases in a locality, so would the number of jobs, but that is not the case with this data. Therefore, a new analysis has been performed.

The second model developed uses the raw data collected from the IDMB in addition to data from other sources. The majority of the information was collected from Mexico's National Institute of Geography and Statistics (INEGI) and Mexico's census department (CONAPO). Census data is collected every five years in Mexico and INEGI has administered municipal questionnaires since 1990. The public finance data were validated by the data published by the Mexican Congress' National Deputies (CEPF). Municipal GDP, the economic development dependent variable, was gathered from various sources, including private sector banks and other academic studies. ${ }^{67}$ This variable was developed for this research, as there is not a nationally standardized data

\footnotetext{
67 A special thanks to Fausto Hernandez-Trillo for his assistances to find this data.
} 
point, which is collected by the federal bureaucracy. The years for which the data for Municipal GDP was collected includes 1988, 1990, 2000, 2005, and $2007 .{ }^{68}$

\section{Model 2. Municipal GDP/Per Capita $=(a 1+a 2 \% T O S R+b 3 \%$ Wage Bill $+b 4 \%$ Public Works + b5\% Other Expenditure + b6 Controls)}

The public finance variables of interest include the amount of Total Own-source Revenues (TOSR), which are any property taxes, fines, and fees collected locally minus transfers made by the national government. This gives a measure of the fiscal autonomy that has been developed by a municipality. Secondly, how municipalities make financing decisions is evaluated. This includes expenses towards wage bills (to test the leviathan theory), public works (to test the spillover effects) and other expenditures. Each of these expenditures was created into a variable as a percentage of TOSR for each city. This last variable (other expenditures) was later eliminated from the formal test because it auto correlated with the wage bill and public works expenses. Each of these variables was created as a percentage over the total municipal expenditures to capture how much of the budget was being allocated to each. Table 9.2 defines these variables.

\begin{tabular}{|l|l|}
\hline Table 9.2 Key Public Finance & Variables \\
\hline & Measurements \\
\hline TOSR & Revenue - Transfers $($ Ramo $28+$ Ramo33 $)$ \\
\hline$\%$ TOSR & TOSRp $=($ TOSR/Total Revenues $) * 100$ \\
\hline$\%$ Wage Bill & WAGEp $=($ Wage/TOSR $) * 100$ \\
\hline \% Public Works & PWp $=($ Public Works/TOS $) * 100$ \\
\hline Other expenditures & Other $=$ Total Expenditures $-(\mathrm{PW}+$ Wage $)$ \\
\hline$\%$ Other expenditures & Otherp $=($ Other/TOSR $) * 100$ \\
\hline
\end{tabular}

\footnotetext{
68 Outcomes from the 1988 are not set as per capita so they are not presented here. The most recent cense data to that date is 1990 and will be re-modeled using that years data. Cense data prior to 1990 is not available on the CONAPO Web site.
} 
The results show positive and significant correlation between TOSR and municipal GDP at the 99 percent confidence interval for all years. That is to say that there is a link between the economic development of a community and their efforts at raising local public revenues. This relationship holds strong for the four years tested.

Table 9.3 Results of Economic Development on TOSR in Mexico

\begin{tabular}{|c|c|c|c|c|}
\hline \multicolumn{5}{|c|}{$\begin{array}{l}\text { Results of Region of Economic Development on Total Own Source Revenue } \\
\text { using INEGI Data of the 2,455 Municipalities in Mexico }\end{array}$} \\
\hline \multicolumn{5}{|c|}{ Dependent Variable: GDP/capita } \\
\hline Regressor & 1990 & 2000 & 2005 & 2007 \\
\hline$\%$ TOSR & $\begin{array}{l}.006^{* * *} \\
(.001)\end{array}$ & $\begin{array}{l}120.23^{* * *} \\
(6.30)\end{array}$ & $\begin{array}{l}133.81^{* * *} \\
(3.67)\end{array}$ & $\begin{array}{l}8.11^{* * *} \\
(.098)\end{array}$ \\
\hline \% Wage Bill & $\begin{array}{l}-.003 \\
(.002)\end{array}$ & $\begin{array}{l}200.81^{* * *} \\
(31.107)\end{array}$ & $\begin{array}{l}-.356 \\
(.544)\end{array}$ & $\begin{array}{l}-0.18 \\
(.019)\end{array}$ \\
\hline $\begin{array}{l}\text { \% Public } \\
\text { Works }\end{array}$ & $\begin{array}{l}-.004^{* *} \\
(.006)\end{array}$ & $\begin{array}{l}-30.944^{* * *} \\
(6.598)\end{array}$ & $\begin{array}{l}.002 \\
(.101)\end{array}$ & $\begin{array}{l}-1.19 \\
(.050)\end{array}$ \\
\hline \% Other Exp. & \begin{tabular}{|l|}
$.002^{* *}$ \\
$(.001)$ \\
\end{tabular} & $\begin{array}{l}-35.414^{* * *} \\
(8.645)\end{array}$ & $\begin{array}{l}-.004 \\
(.249)\end{array}$ & $\begin{array}{l}0.46 \\
(0.241)\end{array}$ \\
\hline \multicolumn{5}{|c|}{ Summary Statistics } \\
\hline $\mathrm{R} 2$ & .060 & 0.260 & 0.396 & 0.037 \\
\hline $\mathrm{N}$ & 2251 & 1308 & 2070 & 1913 \\
\hline
\end{tabular}

The expenditures towards wage bill and public works in 2000 also show positive correlations. The negative result as regards to the public works variable is puzzling. Perhaps this is because unconditional transfers are used to build public works. The negative correlation with economic growth suggests that national transfers allocated to poor municipalities are used for public works. Because the wage bill is only significant in 2000, a conclusion cannot be made if the city will pay more for that activity.

\subsection{Summary Discussion}

Results of these regression tests are preliminary, but they do appear to confirm the assumptions found in the qualitative analysis. A more economically developed 
municipality will encourage public officials to collect more local taxes. Local governments can promote and increase growth for the country when they collect more own source revenue. When local governments have higher levels of economic development, city officials are more able to collect taxes, which are used to spur economic growth. Even with the high levels of expenditure decentralization that have occurred in Mexico since 1997, the correlation remains the same. Further analysis must be done to understand Mexico's efforts at strengthening economic development through expenditures for public works.

The public works results relates to the outcomes of the qualitative analysis, which suggest that public authorities would rather seek funds from higher-level government to avoid bearing the political costs of raising taxes locally. The next chapter seeks to determine if this result is generalizable to additional countries in Latin America. It returns to the question of the three types of autonomy (administrative, political, or fiscal) to see how mayors and other local authorities see the changes of these effects. The chapter tests if political decentralization is relevant for the creation of business development within the region. In so doing, it attempts to tie together the qualitative and quantitative sections of this research. 


\section{CHAPTER X}

\section{STATISTICAL ANALYSIS OF A SURVEY OF LOCAL AUTHORITIES IN LATIN AMERICA}

\subsection{Introduction}

Arguably, recent local economic development (LED) initiatives in Latin America are a consequence of the decentralization processes currently underway in the region. Specific efforts to promote LED policies, both by national governments and local areas, are driven by a complex set of political and economic factors. Some countries, such as Mexico, have started to offer incentives as a way to attract foreign investment. Others have provided promotional advertisements to retain or draw manufacturing or foreign enterprises into their areas. Still others encourage small and medium enterprises to grow by creating a positive policy environment with which to work, such as in Argentina. The key issue for Latin American countries is to decipher which factors are best to foster local economic development.

In this chapter a survey that serves to evaluate those factors, which influence the number of businesses created in a local area is analyzed. It summarizes the assessment of mayors, city council members, and executives from 13 countries in Latin America as a way to better understand how these local public officials are implementing pro-business policies to improve their local areas. A statistical test is executed, which considers fiscal, administrative, and political autonomy, and also controls for municipal environmental factors. The chapter is organized into the following sections. First, it briefly provides a theoretical perspective as to why decentralization is best to promote business friendly policies and ultimately economic development for a local area. Next, it describes the 
research design. Finally, this chapter tests the purposed theoretical perspective and provides tentative conclusions.

\subsection{Theoretical Perspective}

Local governments might be better equipped to provide favorable policy environments to promote economic development. For example, municipal governments could provide more precisely tailored financial programs and incentives for business to develop in a local area. Such programs include offering tax incentive programs. This includes organizing enterprise zones programs to create incentives for business development, as in the United States and Brittan. It may also include issuing municipal bonds to finance necessary infrastructure and providing education and training programs that can help create a competitive workforce. The current assumption is that stronger and more effective decentralization will inspire communities to manage their local resources better, create improved fiscal controls, encourage the elaboration of valuable economic development plans and promote effective and efficient spending for social policies. In turn, this will raise the per-capita income of residents for future economic development.

Recently much attention has been placed on these bottom-up mechanisms to promote growth in a particular location within the global economy (Friedman 2005; Porter 2005; Florida 2007). Scholars are evaluating whether local economies can grow by providing policy recommendations to encourage development in a particular locality. Methods such as providing tax incentives, issuing bonds, collecting property taxes and ultimately, effectively managing national governments appropriations may encourage local development (Delahite 2005; Feiock 2007). Therefore, this chapter directly tests of the theories of Peterson (1996), Oates (1995) and Tiebout (1956) utilizing measures of 
business-friendly policies as the dependent variable, while using the concept of decentralization as the key independent variable.

The question stimulating this part of the research effort is whether fiscal, political or administrative decentralization and/or the existence of business-friendly policies have an effect on the number of businesses reported by a local authority. By using a multilinear regression, this chapter tests if a mayor or local authority reports having a high number of businesses within communities they will also report being a more autonomous local government. This research seeks to determine if local government officials (mayors) report having increased the number of public programs to promote business-friendly policies within their communities, thus creating more SMEs, and, ultimately, increasing the number of entrepreneurs in their communities. The expected outcome is that if the local authority indicates a high level of fiscal, political or administrative decentralization, they will be more likely to promote business-friendly policies within their communities. This assumption puts business-friendly policies as the dependent variable.

\subsection{Research Design}

The unit of analysis of this section of the research is the opinions and perceptions of mayors and local authorities towards decentralization policies. The data come from the Inter-American Conference of Mayors and Local Authorities, an event organized annually by the Miami-Dade County government and Florida International University. For nearly two decades, the event has brought an average of 500 mayors and local officials to Miami, Florida from all over Latin America to discuss municipal level problems and provide some tentative solutions. The first event, co-sponsored by the United States Agency for International Development, the Inter-American Development 
Bank, the World Bank, and the Organization of American States, was held in Washington, D.C. in 1996 and approximately 100 local officials attended. The second conference was held in Miami and almost 200 individuals participated. Since that time, the event has grown and is considered one of the primary gatherings of local leaders throughout the hemisphere to occur each year.

Beginning in 2005, the Inter-American Foundation (IAF), a United States government agency that promotes economic development by providing grants to community-based groups, sponsored a survey of participants. The IAF desired to understand the current climate for their grant making at the local level as well as the perceptions and challenges the mayors of the hemisphere faced. Each year, they have implemented different surveys related to the various themes of the conference. For example, the 2007 conference theme was Building the Competitive Municipality: Promoting Collaboration for Development, which yielded valuable responses to understanding mayors' perceptions of growth and economic development policies. The survey conducted in 2007 provides a convenient sample of mayors, city council member and executives from 13 countries in Latin America. The number of attendants who received the questionnaire was 512 and 315 responded the survey. Table 10.1 provides the information regarding the sample, including the countries of origin, the job the respondents and the size of their towns, cities, or metropolitan areas. 


\begin{tabular}{|c|c|c|c|c|c|c|}
\hline \multicolumn{7}{|c|}{ Table 10.1 Sample Frequencies of the Survey Statistics } \\
\hline \multicolumn{2}{|c|}{ Country of Respondent } & \multicolumn{2}{|c|}{ Percentage } & Job Type by Gender & Male & Female \\
\hline \multicolumn{2}{|c|}{ Argentina } & \multicolumn{2}{|c|}{$1 \%$} & Mayor & $87 \%$ & $13 \%$ \\
\hline \multicolumn{2}{|l|}{ Bolivia } & \multicolumn{2}{|c|}{$7 \%$} & City Council Member & $63 \%$ & $37 \%$ \\
\hline \multicolumn{2}{|l|}{ Chile } & \multicolumn{2}{|c|}{$2 \%$} & Private Sector Executive & $64 \%$ & $36 \%$ \\
\hline \multicolumn{2}{|l|}{ Colombia } & \multicolumn{2}{|c|}{$9 \%$} & Total & $75 \%$ & $25 \%$ \\
\hline \multicolumn{2}{|l|}{ Dominican Republic } & \multicolumn{2}{|c|}{$8 \%$} & \multicolumn{3}{|l|}{ 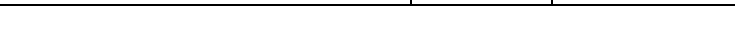 } \\
\hline \multicolumn{2}{|l|}{ Ecuador } & \multicolumn{2}{|c|}{$16 \%$} & \multicolumn{3}{|l|}{ Job Type (Total) } \\
\hline \multicolumn{2}{|l|}{ Honduras } & \multicolumn{2}{|c|}{$16 \%$} & \multicolumn{2}{|l|}{ Mayor } & $50 \%$ \\
\hline \multicolumn{2}{|l|}{ Nicaragua } & \multicolumn{2}{|c|}{$12 \%$} & \multicolumn{2}{|l|}{ City Council Member } & $37 \%$ \\
\hline \multicolumn{2}{|l|}{ Panama } & \multicolumn{2}{|c|}{$2 \%$} & \multicolumn{2}{|l|}{ Private Sector Executive } & $13 \%$ \\
\hline \multicolumn{2}{|l|}{ Paraguay } & \multicolumn{2}{|c|}{$6 \%$} & \multicolumn{2}{|l|}{ Total } & $100 \%$ \\
\hline \multicolumn{2}{|l|}{ Peru } & \multicolumn{2}{|c|}{$9 \%$} & & & \\
\hline El Salvador & & $12^{9}$ & & & & \\
\hline Total & & 100 & & & & \\
\hline Size of Place of & Drigin & & & Municipal Size & & \\
\hline & Numb & & Percentage & & Number & Percent \\
\hline National Capital & 13 & & $4 \%$ & Less than $20 \mathrm{~K}$ & 110 & $35 \%$ \\
\hline State Capital & 50 & & $16 \%$ & Between 20K-50K & 97 & $31 \%$ \\
\hline City & 136 & & $44 \%$ & Between $50 \mathrm{~K}-100 \mathrm{~K}$ & 54 & $17 \%$ \\
\hline Town & 113 & & $36 \%$ & Between 100K-1 Million & 45 & $14 \%$ \\
\hline Total & 312 & & $100 \%$ & More than 1.000 .000 & 9 & $3 \%$ \\
\hline & & & & Total & 315 & $100 \%$ \\
\hline
\end{tabular}

The answers to all questions reflect the perception of the responding local officials. There are no controls to determine the accuracy of the responses. Nevertheless, the individual respondents as local public officials are highly knowledgeable of the development in their communities. Since this is a random sample, there is no verification of data by respondents. City identifications are in the dataset but there is no secondary source, which can be used with either GDP, number of SMEs or controls at the municipal level across the 13 countries. Therefore, the data represents the best perceptions of local public officials from throughout Latin America and should be interpreted as such.

Within this chapter, several models are created to test the various hypotheses. The first test used the number of business cited to have been established within the municipality as the dependent variable, and the second test used the number of new businesses the municipality increased over the previous year. These variables 
demonstrate the relative strength of the local economy (see table 10.2 for the description of the variables). They are count variables, which estimate the number of businesses (as a proxy for measuring entrepreneurship). However, these variables do not disaggregate for the size of the firms.

\begin{tabular}{|c|c|c|}
\hline Variable & Type & Description \\
\hline Strength of Local Economy & Count & Measured by the \# of businesses in municipalities \\
\hline $\begin{array}{l}\text { Increasing Strength of Local } \\
\text { Economy }\end{array}$ & Count & $\begin{array}{l}\text { Measured by the \# of new registered businesses in } \\
\text { municipalities over the last year }\end{array}$ \\
\hline Budget Autonomy & Ordinal & Defined budget, creating and calculating taxes and expenses \\
\hline $\begin{array}{l}\% \text { of Budget Autonomy } \\
\text { (aka Autonomy) }\end{array}$ & Interval & $\begin{array}{l}\text { Measures of the budget by inputs of local taxes (property, } \\
\text { fees and fines), and public loans/debt minus inter- } \\
\text { governmental transfers and international or philanthropic aid }\end{array}$ \\
\hline Political Autonomy & Ordinal & Level of decision making authority, originating internally \\
\hline Administrative Autonomy & Ordinal & $\begin{array}{l}\text { Level of capacity to define municipal authorities, processes, } \\
\text { and purchases. }\end{array}$ \\
\hline Business Friendliness & Count & $\begin{array}{l}\text { Composite of Question \#13 which asked what a series of } \\
\text { questions to determine what pro-business policies the } \\
\text { municipality has implemented in the past year. }\end{array}$ \\
\hline \multicolumn{3}{|l|}{ Control Variables } \\
\hline Total Budget & Interval & Estimated in US dollars, measured in thousands \\
\hline Population of Municipality & Interval & Ranges between Less than $20 \mathrm{k}$ to More than 1 million \\
\hline Administrative Territory & Interval & $\begin{array}{l}\text { Respondent from National Capital, State/Provincial Capital, } \\
\text { City, Town }\end{array}$ \\
\hline Poverty in Municipality & Interval & Measured in $25 \%$ increments \\
\hline
\end{tabular}

The last test uses the number of business friendly policies that the local government has developed within the municipality as the dependent variable and was regressed on the various degrees of decentralization (political, administrative, and fiscal) that each respondent provided. The business friendly policy variable is an index of questions asking respondents to indicate yes or no if the authority had implemented probusiness type policies in their municipalities (see table 10.3 for a list of the questions asked). They include setting up local economic development promotional offices; advertising local products in fairs and events; registering commercial plants and productivity activities; organizing business connections with the local business 
community; developing support programs for new small businesses. These responses

were summed to create an ordinal variable.

\begin{tabular}{|l|l|}
\hline Table 10. 3 Business Friendliness Questions & \\
\hline Please indicate the interest in the following: & $\begin{array}{l}\text { Yes, we } \\
\text { have }\end{array}$ \\
\hline 1. The municipality has a local economic development promotional office & \\
\hline 2. The municipality organizes annual fairs and carnivals to advertise local products & \\
\hline 3. There are prizes and annual acknowledgement of best business and entrepreneurs & \\
\hline 4. The municipality has up-to-date maps and locations of local businesses & \\
\hline $\begin{array}{l}\text { 5. The local government is open to free access of information to open businesses: access, roads, } \\
\text { and productive infrastructure, among other things? }\end{array}$ & \\
\hline $\begin{array}{l}\text { 6. The local government has one-window to set up business activities, commercial and } \\
\text { industrial licensing? }\end{array}$ & \\
\hline 7. The municipality has formal connections to the local business community & \\
\hline 8. The municipality has developed support programs for new small business leaders? & \\
\hline $\begin{array}{l}\text { 9. The municipality has an updated plan of registered commercial plants and productivity } \\
\text { activities in your area? }\end{array}$ & \\
\hline 10. The municipality receives of international cooperation? & \\
\hline $\begin{array}{l}\text { 11. The municipality has partnerships with local organizations: city sisters, with local } \\
\text { universities, international cooperation agencies }\end{array}$ & \\
\hline 12. The municipality is a member of an inter- municipal association for economic development & \\
\hline 13. The municipality administers a micro-credit plan for small and medium size businesses & \\
\hline 14. Other (specify) & \\
\hline
\end{tabular}

Key independent variables include the decentralization indicators. First, budget autonomy was measured as an ordinal variable and is the amount of perceived fiscal decentralization possessed by each local authority. This is defined as the perceived autonomy to create, approve and manage taxes and expenditures in the local budget. This was similar to administrative and political autonomy, which are also ordinary values measured as the level of capacity to define municipal authorities, processes, and purchases, and second, the level of decision making authority, originating internally within the municipality. Finally, an additional indicator for budget autonomy was created. It was a percentage of the local revenues (property, fees and fines) and public debt minus inter-governmental transfers and international or philanthropic aid. Respondents filled in this question using a percentage of budget inputs, whereas each budget input, i.e. taxes 
(property, fees and fines), public debt, inter-governmental transfers and international philanthropic aid, had a line and together were required to total 100. Thus, there were two measures for fiscal decentralization: 1) the respondent's perception of budget autonomy measured as a 1-3 ordinal value; and, 2) as the percentage of budget autonomy measured as own-source revenue collected at the local level.

Control variables included in the data set evaluate the types of municipalities. Questions ranged from the country of origin to typical socio-economic qualifiers such as total municipal budget, administrative territory (whether the respondent works in a capital city government or local municipality) and the perception of poverty level. Control variables include: the total budget of the municipality (estimated in US dollars, measured in thousands); the population of municipality measured in ranges between less than $20 \mathrm{k}$ to more than one million; type of administrative territory (for which the respondent characterized their city as the national capital, state/provincial capital, city, or town) and the level of perceived poverty in the municipality, which was measured in 25 percent increments.

This last variable is the respondents' perception of poverty in the municipality relative to other areas and is measured an ordinal value. This is particularly interesting because participants, and people in general, often believe they are relatively "poorer" than their neighbor and therefore need more national assistance. As noted above, the decentralization literature suggests that a municipality with a higher perception of poverty may be more likely to request transfers from the national government and be less reliant on the local economy. Thus, they may be less likely to cite job creation by SMEs within their areas. 


\subsection{Statistical Techniques and Results}

The major dependent variables used to test for the first hypothesis are the number of business and new businesses developed within a municipality. But because of the large dispersion between respondents' selection of the number of businesses created in their municipality and the number of new businesses model specification errors occurred. Table 10.4 illustrates the descriptive statistics for this test. Since many of the mayors estimated responses, some suggested that there were 100 new businesses created the first year and 5,000 created in the subsequent year.

\begin{tabular}{|l|l|l|l|l|}
\hline Table 10.4 Descriptive Statistics of Variables (obs=321) \\
\hline Variable & Mean & Std. Dev. & Min & Max \\
\hline $\begin{array}{l}\text { Strength of Local Economy } \\
\text { (Numbiz) }\end{array}$ & 891.01 & 4082.934 & 0 & 50000 \\
\hline $\begin{array}{l}\text { Increasing Strength of Local } \\
\text { Economy (Newbiz) }\end{array}$ & 171.7 & 588.0923 & 0 & 4800 \\
\hline Business Friendliness & 5.38 & 3.030404 & 0 & 13 \\
\hline Political Autonomy & 2.03 & .7548189 & 0 & 3 \\
\hline Administrative Autonomy & 2.03 & .6934238 & 0 & 3 \\
\hline Budget Autonomy & 1.899 & .763812 & 0 & 3 \\
\hline \% of Budget Autonomy & 41.46 & 36.19737 & 0 & 100 \\
\hline Control Variables & $1.67 \mathrm{e}+09$ & $1.72 \mathrm{e}+10$ & 793 & $1.83 \mathrm{e}+11$ \\
\hline Total Budget & 2.42 & .6311043 & 1 & 3 \\
\hline $\begin{array}{l}\text { Population of Municipality } \\
\text { Administrative Territory }\end{array}$ & 2.19 & 1.14439 & 1 & 5 \\
\hline $\begin{array}{l}\text { Poverty in Municipality } \\
\text { *Italics are dependent variables }\end{array}$ & 3.40 & 1.177602 & 1 & 5 \\
\hline
\end{tabular}

Because of the model specification errors, a new logit model was purposed over a standard OLS model ${ }^{69}$ After creating a log to correct for the dispersion of the dependent

\footnotetext{
69 Tests to evaluate multicollinearity, heteroskedasticity, and model misspecification found a potential for serious errors in the preliminary results. First, a pair-wise and VIF tests $(\mathrm{VIF}=1.16)$ found a low problem with mulitcollinearity. Subsequently, a Breusch-Pagan and the Cook-Weisberg were carried out to test for heteroskedasticity, the results indicated chi2 of 103.87 and the probability of the chi2 to be less than 0.00 respectively. Since the chi 2 is less than .05 there is a heterskedasticity problem. This suggests that there is a problem with the standard error and the $\mathrm{T}$ and $\mathrm{F}$ test may report statistical significance, even if they are not. Additional tests of model specification confirmed that there are serious errors in the results. For example, the Reset Ramsey test using powers of the fitted value of new businesses outputted F $(3,165)=8.09$ resulting in the model that cannot reject the null hypotheses (Ho: model has no omitted variables).
} 
variable, the outcome of the linear regression (BLUE) resulted in the positive outcome of political autonomy and the control variable administrative territory reported to correlate. The Negative Binominal model was suggested and found to be statistically sound and the best fit for the data, with the R squares of over .05 for the first model and over .06 for the second one.

By using this Negative Binomial model, the results show that the likelihood of respondents to report a higher number of new businesses added last year leads to a more likely (positive) assessment of having business friendly policies implemented in their municipality and greater the likelihood of having higher amounts of political autonomy in terms of making their own decisions (see table 10.5). This confirmed the first hypotheses that stated that when local government officials (mayors) reported being more decentralized (politically was more often significant than administrative or fiscally) they were also more likely to support techniques of local economic development such as business friendliness policies within their communities.

The number of businesses and additional new businesses resulted in statistically significant results for business development in terms of the number of business friendly policies, political, administrative, and percent budget autonomy (see tables 10.5 and 10.6). To have a vibrant economy, municipalities must also have a highly developed government as well as local industry to engage in pro-growth policies. Governmental structure does matter when reporting job creation. The higher the numbers of businesses reported showed a strong positive correlation with political and administrative autonomy. 


\begin{tabular}{|c|c|c|c|c|}
\hline \multicolumn{5}{|c|}{ Table 10.5 Statistical Analysis Results Hypothesis \#1 } \\
\hline \multirow{2}{*}{\multicolumn{5}{|c|}{$\begin{array}{l}\text { Results of Regression of Business Development on the use of business friendly policies and } \\
\text { decentralization variables Using Mayors and Authorities opinions. OLS Model } \\
\text { Dependent Variable: Strength (Model 1 \&2) and Increasing (Model } 3 \text { \&4) of Local Economy (measure } \\
\text { of small business creation) using a log for number of businesses and new business created. }\end{array}$}} \\
\hline & & & & \\
\hline Regressor & (1a) & $(1 \mathrm{~b})$ & $(2 a)$ & $(2 b)$ \\
\hline Business Friendliness (X1) & $\begin{array}{c}.074 \\
(.072)\end{array}$ & $\begin{array}{c}.058 \\
(.072)\end{array}$ & $\begin{array}{c}.107 \\
(.067)\end{array}$ & $\begin{array}{c}.090 \\
(.066)\end{array}$ \\
\hline Political Autonomy (X2) & $\begin{array}{l}.611 * * \\
(.283)\end{array}$ & $\begin{array}{l}.630 * * \\
(.281)\end{array}$ & $\begin{array}{l}.666^{* * *} \\
(.280) \\
\end{array}$ & $\begin{array}{l}.685^{* *} \\
(.281)\end{array}$ \\
\hline Administrative Autonomy (X3) & $\begin{array}{c}.467 \\
(.396)\end{array}$ & $\begin{array}{c}.270 \\
(.346)\end{array}$ & $\begin{array}{c}.038 \\
(.403)\end{array}$ & $\begin{array}{l}-.218 \\
(.367)\end{array}$ \\
\hline Budget Autonomy (X4) & $\begin{array}{l}-.220 \\
(.310)\end{array}$ & --------- & $\begin{array}{l}-.300 \\
(.288) \\
\end{array}$ & --------- \\
\hline$\%$ of Budget Autonomy (X5) & --------- & $\begin{array}{c}.006 \\
(.006)\end{array}$ & --------- & $\begin{array}{c}.006 \\
(.005)\end{array}$ \\
\hline Intercept & $\begin{array}{c}-.171 \\
(1.563) \\
\end{array}$ & $\begin{array}{c}-.290 \\
(1.543)\end{array}$ & $\begin{array}{c}1.645 \\
(1.490) \\
\end{array}$ & \\
\hline \multicolumn{5}{|l|}{ Summary Statistics } \\
\hline $\mathrm{R} 2$ & 0.3231 & 0.3328 & 0.2694 & 0.2719 \\
\hline $\mathrm{N}$ & 118 & 119 & 109 & 109 \\
\hline
\end{tabular}

\begin{tabular}{|c|c|c|c|c|}
\hline \multicolumn{5}{|c|}{$\begin{array}{l}\text { Results of Negative Binomial of Business Development on the use of business friendly policies and } \\
\text { decentralization variables Using LAC Mayors and Authorities opinions. }\end{array}$} \\
\hline \multicolumn{5}{|c|}{$\begin{array}{l}\text { Dependent Variable: Strength (1\&2) and Increasing Strength (3\&4) of Local Economy (measure of } \\
\text { small business creation) }\end{array}$} \\
\hline Regressor & (1a) & $(1 \mathrm{~b})$ & $(2 a)$ & $(2 b)$ \\
\hline Business Friendliness (X1) & .118 & $\begin{array}{l}.139 * \\
(.077)\end{array}$ & $\begin{array}{c}.268 * * * \\
(.076)\end{array}$ & $\begin{array}{c}.256 * * * \\
(.075)\end{array}$ \\
\hline Political Autonomy (X2) & $\begin{array}{l}.560 * \\
(.300)\end{array}$ & $\begin{array}{c}.316 \\
(.300)\end{array}$ & $\begin{array}{l}.791 * * \\
(.380)\end{array}$ & $\begin{array}{l}.794 * * \\
(.386)\end{array}$ \\
\hline Administrative Autonomy (X3) & $\begin{array}{l}.293 \\
(.475) \\
\end{array}$ & $\begin{array}{l}.661 * \\
(.375) \\
\end{array}$ & $\begin{array}{l}-.213 \\
(.462) \\
\end{array}$ & $\begin{array}{l}-.279 \\
(.418)\end{array}$ \\
\hline Budget Autonomy (X4) & $\begin{array}{c}.366 \\
(.360)\end{array}$ & --------- & $\begin{array}{c}-.500 \\
(.368)\end{array}$ & -------- \\
\hline$\%$ of Budget Autonomy (X5) & --------- & $\begin{array}{l}.018 * * \\
(.008)\end{array}$ & --------- & $\begin{array}{c}.013 \\
(.008)\end{array}$ \\
\hline Intercept & -1.522 & -1.520 & -1.330 & -1.424 \\
\hline \multicolumn{5}{|l|}{ Summary Statistics } \\
\hline $\mathrm{R} 2$ & 0521 & 0553 & .0669 & .0693 \\
\hline $\mathrm{N}$ & 122 & 123 & 118 & 119 \\
\hline
\end{tabular}


Next the second and the third hypothesis were tested using the mayors' report of business friendliness policies as the dependent variable. This is used to analyze the effect of these policies on the responses of the local authorities' opinion on decentralization and the importance of governmental structure (hypothesis 2). More specifically, for the last test (hypothesis 3), which measured the amount of fiscal decentralization in terms of budget autonomy (measured also as the ratio of own-source revenues over intergovernmental transfers) as the principal independent variable. As Table 10.7 indicates that the variables are not significant. Moreover, even with positive Ramsey reset tests for both models the data fits, which the outcomes for hypothesis test two and test three find few significant variables of importance. ${ }^{70}$

Only the first test finds a significant positive correlation with budget autonomy (at the 90 percentage confidence level). It is likely that when respondents report that they implement more business friendliness programs they also report that they have more budget autonomy. This confirms the third hypothesis. Significant variables include the total annual budget reported to operate in the city, the territorial size of the city (the larger the size of the city the more significant) and the higher the perceptions of it being in poverty. These correlate with the greater the likelihood that the mayors will administer business friendliness policies in their jurisdictions.

\footnotetext{
70 The Ramsey reset test for the second model $(1 \mathrm{a}+\mathrm{b})$ using powers of the fitted values of business Friendliness Policies present $F(3,182)=0.56$ and the probability of the $F$ is equal to 0.6453 . Suggesting that Ho: model has no omitted variables. And event with the addition of the dummy variables third and final model $(1 \mathrm{a}+\mathrm{b})$ also are fitted with the $\mathrm{F}(3,172)=0.89$ the probability of the $\mathrm{F}$ is equal to 0.4480 .
} 


\begin{tabular}{|c|c|c|c|c|}
\hline \multicolumn{5}{|c|}{$\begin{array}{l}\text { Table 10.7 Statistical Analysis Results Hypothesis \#2 and \#3 } \\
\text { Results of Regression of business friendly policies on the level of decentr } \\
\text { Authorities opinions. (OLS model) }\end{array}$} \\
\hline \multicolumn{5}{|c|}{ Dependent Variable: business friendliness policies on decentralization } \\
\hline Regressor & (1a) & (1b) & $\begin{array}{c}(2 a) \\
+ \text { Dummies } \\
\end{array}$ & $\begin{array}{c}(2 \mathrm{~b}) \\
+ \text { Dummies } \\
\end{array}$ \\
\hline Political Autonomy (X2) & $\begin{array}{c}.144 \\
(.299)\end{array}$ & $\begin{array}{c}.254 \\
(.296)\end{array}$ & $\begin{array}{l}-.021 \\
(.306)\end{array}$ & $\begin{array}{c}.035 \\
(.301)\end{array}$ \\
\hline Administrative Autonomy (X3) & $\begin{array}{c}-.596 \\
(.383)\end{array}$ & $\begin{array}{l}-.334 \\
(.336)\end{array}$ & $\begin{array}{l}-.622 \\
(.381)\end{array}$ & $\begin{array}{l}-.431 \\
(.337)\end{array}$ \\
\hline Budget Autonomy (X4) & $\begin{array}{l}.583 * \\
(.339)\end{array}$ & -------- & $\begin{array}{c}.468 \\
(.343)\end{array}$ & -------- \\
\hline$\%$ of Budget Autonomy $(\mathrm{X} 4 *)$ & ---------- & $\begin{array}{c}.010 \\
(.006) \\
\end{array}$ & -------- & \\
\hline Total Budget & $\begin{array}{l}3.17 \mathrm{e}-11^{*} \\
1.15 \mathrm{e}-11\end{array}$ & $\begin{array}{l}3.40 \mathrm{e}-11^{* *} \\
(1.15 \mathrm{e}-11)\end{array}$ & $\begin{array}{l}2.74 \mathrm{e}-11 * * \\
(1.16 \mathrm{e}-11)\end{array}$ & $\begin{array}{c}2.84 \mathrm{e}-11^{* *} \\
(1.15 \mathrm{e}-11)\end{array}$ \\
\hline Population & $\begin{array}{c}.037 \\
(.324) \\
\end{array}$ & $\begin{array}{c}-.127 \\
(.324) \\
\end{array}$ & $\begin{array}{c}1.075 \\
(1.060) \\
\end{array}$ & $\begin{array}{r}-.187 \\
(.846) \\
\end{array}$ \\
\hline Administrative Territory & $\begin{array}{l}.221 \\
(.186)\end{array}$ & $\begin{array}{c}.202 \\
(.188)\end{array}$ & $\begin{array}{l}.339^{*} \\
(.189)\end{array}$ & $\begin{array}{c}.308 \\
(.190)\end{array}$ \\
\hline Poverty & $\begin{array}{c}-.470^{* *} \\
(.190)\end{array}$ & $\begin{array}{c}-.417^{* *} \\
(.192)\end{array}$ & $\begin{array}{c}-.510^{* *} \\
(.200)\end{array}$ & $\begin{array}{c}--.459 * * \\
(.198)\end{array}$ \\
\hline Paraguay & -------- & -------- & $\begin{array}{l}-4.80^{*} \\
(2.19)\end{array}$ & $\begin{array}{l}-2.80^{*} \\
(1.683)\end{array}$ \\
\hline Intercept & 6.400 & 6.552 & 5.128 & 6.486 \\
\hline \multicolumn{5}{|l|}{ Summary Statistics } \\
\hline $\mathrm{R} 2$ & 0.114 & 0.117 & 0.213 & 0.223 \\
\hline Adjusted R2 & .0796 & 0.083 & 0.135 & 0.147 \\
\hline $\mathrm{N}$ & 191 & 193 & 191 & 193 \\
\hline
\end{tabular}

The third model, and final test in this study, added dummy variables for each of the countries. Not only did this increase R squared but also the robustness of the models (see models $2 \mathrm{a}$ and $2 \mathrm{~b}$ ). Unfortunately, only the respondents from Paraguay appeared to have significant results from having implemented more business friendliness policies. The results show they cannot agreed or disagreed that when the respondents from particular country stated that they had an increase the number of business friendliness policies within their communities, they created more SMEs or the number entrepreneurs in their communities, agreed to have more decentralization or the budget autonomy (local 
tax revenue over transfers from their national governments). The outcomes of these tests are too tenuous and additional research is need for a stronger outcome.

\subsection{Summary Discussion}

While the results are rather provisional, there were several problems identified with the use of the data set. Although the number of responses fell to just over 100 for each test in the first model and around 200 for the second and third models, they are still statistically reliable. This drop in the sample size is due to the fact that several respondents simply left responses blank and therefore were dropped in the Stata computer program. Other reasons for not responding to this question could be a matter of corruption or some personal or family involvement in a major local business. Regardless, the response merited additional attention. Further tests are needed to regress opinion data on factually accurate secondary sources, which include better indicators of decentralization, job creation and promotion of business friendliness policies. Since the respondents attended the event in 2007 and are random, the type of necessary fact check to see if they are reporting accurately their impressions is virtually impossible. These responses represent what local government officials are thinking in terms of job creation and establishing business friendliness policies.

Despite these issues, the results also show that political autonomy and the implementation of business friendly policies at the local level are important for attracting new businesses to a municipality (model 1). Although, fiscal and administrative autonomy are less influential, the political autonomy is important for public administrators, which is also important for economic development polices to emerge from local governments. Municipal leaders know that their political autonomy is 
important to make decisions on policies for the communities. These decisions may not be related to the political official or party in office (at the state or national level). The mayors know that they need to establish policies to attracted new businesses in their municipality to encourage growth and development and this decision may not be independent from other political influence.

Specifically, government structure does matter when analyzing effort by a mayor or local official to promote economic development within their municipality. This study shows that the decentralization process is important for mayors to increase the promotion of economic growth and will help support the enabling environment to set-up, finance, market and support the establishment of SMEs in their physical localities. The study confirms the hypothesis that more autonomous municipalities (measured as the higher percentage of government revenue is generated at the local level) promotes more SMEs and pro-business type governments programs, which ultimately induces economic development. Even though fiscal and administrative autonomy is less statically strong (model $1 \mathrm{a}+\mathrm{b}$ ), it does indicate that local authorities are not as knowledge about their fiscal and administrative needs to develop new businesses in their communities.

Ultimately, this chapter suggests that for local economic development to take place, mayors, and local officials need to begin to realize that they are major players in their economies. These political actors also can be helpful for the development of their countries. Local elites often complain that they lack the necessary administrative and fiscal resources to produce the necessary policies in their cities. This may help push for further decentralization reforms into the future. 


\section{CHAPTER XI}

\section{DISCUSSION AND CONCLUSIONS}

\subsection{Introduction}

This dissertation examined local governments' efforts to collect taxes and promote economic development in Latin America. It used a mixed methodology to explore how cities make decisions to innovate, develop, and finance economic development programs. First, this research used a comparative analysis of intergovernmental relation in two federalist countries-Argentina and Mexico-to describe how decentralization has taken into effect within the region. Then six cities were compared — Santa Fe, Rosario, Rafaela, Leon, Guanajuato, and San Miguel de Allendeto better describe the fiscal constraints and economic development initiatives undertaken by each city. Finally, the research used statistical regressions to test data gathered from Mexico and Latin American municipal governments to test whether autonomous cities are better equipped at establishing economic development programs.

Decentralization reforms perform in a dynamic process, which may change at any time. Argentina's recent re-centralization has created political conflict and overall institutional weakness throughout its subnational governments, causing the national government serious strains on meeting basic public policy goals. In contrast, Mexican decentralization policy, especially after the fiscal coordination law of 1997, has strengthened subnational governments. Although, it can be argued that, municipalities still need to demand a more prominent role in the policy making process. In both countries, the decentralization process has empowered state governments. However municipalities still lack incentives to increase revenues. Even though municipalities have 
limited abilities to levy charges, fines fees and property, they have shown a positive correlation between local own-source revenue and economic growth.

This dissertation found that decentralization policies are difficult to decipher from other political and economic reforms. The rationale for a national government to fiscally decentralize may involve a variety of reasons-including such as macroeconomic stability, economic growth and/or politicians seeking re-election. The policy sequencing (fiscal, administrative, or political decentralization) is somewhat irrelevant since each subnational government faces various constraints at quite different times in its history for different reasons. The effects of the most recent decentralization and centralization policies have influenced the SNG (states in Mexico and provinces in Argentina) financial budgets more directly than they have the local level. Economic development for the cities is much more dependent on national government's macroeconomic policies than micro or local level initiatives. Although LED programs can help local politicians to strengthen their local economies, higher levels of government make political decisions for large infrastructure and public works to be developed. This may have additional implications because financial data are still not available for the local governments. This further exacerbates investment decisions because economic data (such as costs and payments for services) is not used for these decisions. The next section describes these conclusions with more detail and provides implications for the field of public administration.

\subsection{Discussion of Results}

The results of this study also show that economic development is a precursor for collecting more taxes at the local level. With more financial resources, local governments can promote more programs, whether they are funding public works, infrastructure or 
promoting local economic development programs. This study explains how cities are funding their economic development programs. This research examined how cities fiscal capacity, to describe how the municipalities are creating further autonomy (through the collection of own-source revenue). Capacity should be measured in three variables: legal or institutional, human resources/development and mayoral leadership. All of the municipal governments studied were shown to have relative high amounts of human resources capacity to manage public resources, leverage new taxes and administer programs such as cadastre revisions. This suggests that levels of education are rising and higher than expected. Furthermore public officials are clearly able to collect, administer, and manage public resources.

More problematic are the legal or institutional arrangements through which municipal governments function and run. A clear example of this is Mexico with its noreelection rule, the inability to set tax rates and bases and the continuation of its expenditure decentralization policies. Regional control over local elections is also problematic in terms of the ability of Mexican municipalities to collect taxes. Even with these institutional problems, public administrators are seeking independent ways to collect more revenues. Guanajuato's mummy museum is a case in point, but this is more of an exception than the rule. On the whole, public administrators in Latin America are politicians and seek higher positions in the administration. They therefore are more loyal to parties than they are to local constituencies, thus rent-seeking behavior is inherent without clear incentive structures created by the state.

Overall, Chapter IV used a comparative historical approach to federalism to argue that Mexico, even though it was a centralized federation for much of the 20th century, 
began to decentralize when opposition party members came into power in 1980 . Argentina has always been a loose decentralized federation of caudillos but has recently become more centralized order to manage its macro-economic instability by collecting more national level taxes (mostly recently retenciones tax on agricultural exports). Mexico's decentralization has concentrated on administrative and political reforms. Fiscal policy for redistribution of federally funded grants is based on a formula and ultimately has decentralized expenditures (but revenues and the budget process as a whole is totally centralized by the executive).

Chapter V evaluated the abilities of cities to take out public debt as a source of independent revenue for internal decision-making. This research found Argentina has more legal authority to take out loans than their Mexican counterparts, but has recently been more restricted and must have the federal treasury to approve these types of loans. Mexico has always had a very centralized to make decisions to collect and manage loans based on the federal treasury, but has recently opened up to allow two rating and collateral by the promise of inter-governmental transfers. This is the only place that "second generation reforms" are in place and where market-based pricing comes into effect to decide if a city deserves a loan or not. Financial decisions to borrow are based not only on the markets but also on inter-governmental politics since the loans must have approval by either state Congresses or their national finance ministries. Both Mexico and Argentina have had recent fiscal reforms passed by Congresses to approve some debt capacity for local governments. Mexican municipalities take advantage of this benefit and do take out debt—-but the cites that do so are the ones that are wealthier and have better balance sheets to cover larger loans. 
Chapter VI and VII employed a comparative case study approach to analyze the subnational governments. These chapters provide a path dependency argument and implement a bottom up approach to see how the federal decentralization reforms were transforming the local government budgets in their countries. This research suggests that the decentralization reforms have not changed the subnational governments' finances a great deal. Individual city budgets change more when local administrations change office than by changes in federal policy.

Federal policies of decentralization or centralization have had minimal effects on the overall budget capacity of these cities. Local politics and decisions made by politicians take precedence over budgets. This study found that the level of professional development (or the levels of education of public employees) is sufficient to manage funds, which is contrary to what was stated in the previous academic literature. Second, this study finds that projects or personnel funding decisions are most heavily weighted on inter-governmental relationships or personal politics that a city mayor does within his party or the state legislature, or directly with the president. The most fundamental variable is the political structure, whether at the local, state or national level, and the inter-governmental relations that a politician has with other levels of government.

In general, the preceding chapters offer specific lessons learned. Chapter VIII used a comparative public finance approach to understand the six cases. It evaluated size, capacity and legal framework of local budgets and how the decentralization reforms effected the local budgeting of the six cities and the two subnational governments. First there was a comparative analysis of legal structure of the two countries. It was identified that Argentina's cities have more authority to tax, set rates and bases, make budget 
decisions than in Mexico. Mexico's municipalities are extremely limited and subjected to the state governments' final authority for decision-making. But with a comparison of the city budgets, there are few changes in actual budget between the Argentine and Mexican cases. One assumption was that local tax collections should be lower in Mexico than for their Argentine counterparts, but evidence here found that not to be the case. Another assumption was that bigger cities collect more in taxes and spend more per capita, but evidence also found that not true. The expenditure and revenue decisions for the cases presented here are fairly complex, which included assumptions such as smaller cities might spend more on wage bill or larger cities would spend more on public works. This study found that the internal city politics of the mayor and his staff, which often are dependent on the politics of the next higher-level administration (state level in Mexico and provincial level in Argentina) is more important than any other independent variable.

Chapter IX and $\mathrm{X}$ then therefore uses that knowledge to perform a large-scale $\mathrm{N}$ regression to test whether more own source revenue (local tax collection) helps economic development. The statistical models find a positive correlation between economic development (measured in increased GDP) and local own source revenue collection. Chapter IX using data from Mexico finds a positive correlation. Chapter X validates this outcome by using survey data and a regression model to test whether mayors and local authorities see decentralization (political, administrative or fiscal) as essential for job creation in their communities. The outcome shows that mayors see more political and administrative decentralization over fiscal decentralization to increase jobs within their communities. They report relying on their political contacts to make financial decisions over their budgets than collecting taxes themselves. The survey data found that local 
politicians would rather rent-seek higher levels of government to pay for public goods than raise local revenue. This validates the case studies in which the most significant independent variable was inter-governmental political relations.

\subsection{Relationship of Results to Theory}

This dissertation has analyzed six cities efforts to collect tax revenues and promote economic development policies. For many developing countries, decentralization policies have come along with the rise of democratization. While this is true, it is difficult to determine the types of economic policies and political decisions have created the spread of decentralization. What is clear is that decentralization has encouraged cities to become actors in their local economies to spur growth. Mayors and local authorities' actions, whether by increasing public debt, opening offices of economic development, or managing their budget effectively, are actively promoting growth type activities within their communities.

This study has evaluated decentralization through the following approaches: 1) public choice theory; 2) public finance theory; 3) comparative federalism and 4) intergovernmental politics. In public administration, decentralization is used as a theme within comparative administrative systems. Many scholars utilize decentralization as a theory but also have a hard time measuring it conceptually. The public finance literature has measures for decentralization, such as the total own source revenue collection over transfers and the authority to collect local taxes. By using a comparative federalist approach, this research found understanding the relationship between levels of government and encouraging the promotion of economic development activities to be a highly complex matter with many more variables and possible outcomes not used in this 
analysis. When evaluating the tax bases and seeing how to formulate national incentives for the local level, there may be a disconnect of federal policy to local action. Under an institutionalist approach, it is often much more difficult to understand how to apply incentives from the national level to encourage local level tax collection. This goes beyond the capacity question and treats the issue of policy effectiveness to promote the correct incentives from the national government down to the local governments. This is not referring to the education level (professional development) of the local public official. The bigger question relates to the institutional rules of the game and the level of legal authority that cities respond to, for which influence the way subnational leaders react.

This also goes beyond what the public choice scholars call "second generation federalism," which suggests that national governments use market based approaches to find the right fiscal incentives for local governments to foster economic development. Whereas market based approaches are essential to foster economic development, they are relevant for example in rating agencies for municipal bonds, yet most other incentives are not market based but rather political. This suggests a need for a better understanding of institutional relationships between city government officials to higher-level governments, such as a mayor's actions within the inter-governmental process. A better understanding of these relationships can help policy makers propose the correct incentives to expected outcomes. Incentives may be market-based solutions, for example where raters set the bond prices for individual city's borrowing rates, but for the most part the incentives are political in nature. For example, Mexico's "no-reelection rule" creates a disincentive for city officials to encourage more local tax collection and promote revenue "decentralization" (following the 1997 expenditure decentralization efforts). Argentina's 
recent increase in taxes to farmers' commodities - through a centralized tax collection effort-leaves cities like Rosario with less revenue to collect locally and thereby may enhance national government to rent-seeking activities.

The overall idea of path dependency, that "history matters," is important for understanding which nonfinancial incentives helped to create the current policy structure. It also helps to indicate what governments are authorized to do and why they make their decisions. For example, without history it is hard to understand the budget authority and spending decisions of the case studies described in chapter V. It is not just the economic endowments of one city over another, which makes a difference in their development paths, but also where they fit into the inter-governmental system. What a city mayor does to take advantage of their place within the system, such as rent-seeking activities like solicitation of grants or contracts to higher-level governments, or campaigning for other politicians, can also make a difference in the local budget outcome.

Not surprisingly, Tiebout's theory may not be as applicable for developing countries. Local governments in general collect such little amounts of taxes, and citizens are so poor that they are unable to move to where cheaper public services are being offered. Rather in developing countries, citizens are moving to the capital city to get a job. Mid-size cities within the developing world do not compete with one another. More likely is the mega cities effect - capital cities increase population and have to provide more public sources to help all these internal migrants-which generates more centralization because the national government and their relations with their capital cities may be politicized and highly complex. Better public services could be offered by providing transfers that are directly tied to subsidies for economic development, just as 
done with education and health care programs. Ending or minimizing the role of the revenue sharing systems would help many local governments to focus on collecting local revenues instead of relying on transfers.

If wealth is the precursor for economic development (and more decentralization) then developing countries might need to centralize first around larger cities and focus on their development. Thus, larger regional cities could take advantage of IFIs and other private or foreign investments into their regional economies in order to provide the regional spillovers to poorer areas. Therefore, wealthier states may not have as high revenue sharing to the national government, which only later decentralize revenues with others states. Poor states may be able to take advantage of the regional gains and therefore not fall so far behind. By working with mid-size cities to create regional development, this avoids trying to create the correct ratio of revenue sharing and the prefect level of fiscal federalism. This is Rondinelli's idea of developing secondary cities to provide spillover of economic benefits to their regional areas (Cheema and Rondinelli 2007; Rondinelli and Shabbir Cheema 1981; Rondinelli and Cheema 2003). The IADB identified the importance of mid-size cities in order to confront other major problems in a report published in 2001. For them:

Most of the 13,000 local governments in Latin America and the Caribbean are small and medium sized cities, although varying widely in size, geo-graphical location and setting. In general, these cities are increasingly experiencing a whole set of environmental problems, be it due to urbanization, industrial development, land use change or other issues (de Vries, Schuster, Procee, and Mengers 2001)p1.

The issue of economic development is only one factor to resolve additional looming problems expected to occur in developing countries such as in Latin America. The IADB also published "Making Decentralization Work in Latin America and the Caribbean" in 
2001 which suggested that institutional capacities of these subnational governments were too weak to undertake important steps towards fiscal autonomy (Inter-American Development Bank 2001).

This study found that not to be true, that cities in Latin America have various capacities to raise their own revenues and develop their own public policies whether towards economic development, protecting the environment or promoting tourism in their regional areas. The agglomeration of economies around their relative industrial strengthen establish urban centers and cities, which create the fundamental administrative level for which local governments operate. City administrators understand their role to strengthen their local areas and provide good public services, even if the appropriate incentive structure is weak or does not exist.

Finally, what is fundamental in the decentralization process, and for the practice of public administration, is the need for national governments to establish the correct institutional arrangements and incentives for local officials to perform better. Whether this is done through technical equations (as in the Mexican case) or through political rhetoric (the Argentine case using the fiscal pacts) both increases the political decisionmaking of the national government. Allowing central governments to have the authority to make decisions on local economic development activities, such as public works financing, is inefficient. Mexico's no re-election laws and lack of tax authority counteracts cities efforts to collect taxes. Argentina's multiple changes in the past years make it difficult for cities to manage the transferred resources. The national governments must acknowledge that their policies do affect local residents and their incentives to pay taxes, which later affects the way city administrators can improve local public policies. 


\subsection{Implications for Further Research}

More research in this area could be done for answers. Future research could analyze whether the local government are indeed playing a role to improve macroeconomic outcomes. Future research should include evaluations of the flypaper effect, hard and soft budget constraints as well as political institutional rules such as noreelection in Mexico, which perhaps could make the difference as to how local governments behave.

Additional factors could also be important for why local governments make a particular decision. While past literature suggested that capacity is often cited as one of regions biggest problems as to why local governments have not lead to more development. Capacity needs to be better defined, as it could be professional development of public officials or the more technical skills involved in managing a municipality. The concept of capacity should be disaggregated to the size of the location. For example, the population, the territorial size, and the number of residents will determine what types of capacities are needed to run a local government. The outcome of this research has determined that municipal capacity is not the level of education or mayor's leadership abilities; rather it is the institutional framework under which the intergovernmental relations operate that matters for local tax collection and economic development performance.

More research is needed to better understand the impact of legal frameworks, political incentives and financial incentives on and within a municipality's operating environment. Do governments in developing countries need to have better/different institutional arrangements? What and how are cities with larger institutional capacities 
and roles within the inter-governmental system determining how to help other cities (i.e. with economic cooperation or strengthening economic growth for their national governments)? How can public administrators be encouraged to collect more tax revenues? Why are some cities not collecting taxes and spending more, for example, on wage bill, while others are spending on public works? How can national governments strengthen local tax bases while working with local governments to provide more revenue sharing for less economically developed communities? These are several topics in which research could focus on in the future. 


\section{BIBLIOGRAPHY}

Abuelafia, Emmanuel, Sergio Berensztein, Miguel Broun, and Luciano Di Gresia. 2004. "Who decides on Public Expenditures? A poltical Economy Analysis of the Budget PRocess: The Case of Argentina." Washington, DC: Inter-American Development Bank (IDB).

Albuquerque, Francisco. 2004. "Local economic development and decentralization in Latin America." Cepal Review 82.

Alburquerque, Francisco. 1999. Manual del Agente del Desarrollo Local. Colección Manuales. Santiago de Chile: Ediciones SUR.

Alesina, Alberto, Ricardo Hausmann, Rudolf Hommes, and Ernesto Stein. 1999. "Budget Institutions and Fiscal Performance in Latin America." Inter-American Development Bank, Washington, D.C.

Andrews, Cristina. 2008. "Partnership or Recentralization? Municipalities and Federal Anti-Poverty in Brazil." in Annual Conference of International Association of Schools and Institutes of Administration (IASIA) Kampala, Uganda.

Arocena, José 1998. Propuesta metodológica para el estudio de procesos de desarrollo local. Montevideo, Uruguay: CLAEH Serie Desarrollo Local en América Latina.

Bahl, R. and Richard Bird. 2008. "Subnational Taxes in Developing Countries: The Way Forward. ." Public Finance and Budget 28:1-25.

Bahl, R. and L. Johannes. 1994. "Fiscal Decentralization and Inter-governmental Transfers in less Developed Countries." Publius The Journal of Federalism 24:120 .

Bahl, R. O. Y. and Sally Wallace. 2005. "Public Financing in Developing and Transition Countries." Public Budgeting \& Finance 25:83-98.

Bailey, John J. 1990. "Prospects for Democracy in Mexico's Government: The Bureaucracy." Pp. 310 in Prospects for Democracy in Mexico, edited by G. W. Grayson. New Brunswick: Transaction Publishers. 
Bardhan, Pranab and Dilip Mookherjee. 2006. "Decentralisation and Accountability in Infrastructure Delivery in Developing Countries." The Economic Journal 116:101-127.

Bates, James and Ramon Daubon. 2007. "Zonas Autogestionarias: Una Nueva Perspectiva para la Gobernanza Local y el Desarrollo Basada en Acción Ciudadana." Arlington, Virginia: Inter-American Foundation.

Bazan, Lucia, Margarita Estrada, Raul Nieto, Sergio Sanchez, and Minerva Villanueva. 1988. La situacion de los obreros del calzado en Leon, Guanajanto. Mexico City: Centro de Investigaciones y Estudios Superiores en Antropologia Social.

Beck Fenwick, T. 2007. "Do municipalities matter? The politics of decentralized policy delivery." in Annual Conference of the Latin American Studies Association. Montreal, Canada.

Benavides, M. and G. Manrique. 2000. "Parque Industrial del distrito Villa El Salvador: una iniciativa para el desarrollo económico local en Peru." Comisión Económica para América Latina y el Caribe (CEPAL) LC/R.2016.

Benton, Allyson Lucinda. 2001. "Patronage Games: Economic reform, Political Institutions, and the Decline of the Party Stability in Latin America." Dissertation Thesis, Department of Political Science, University of California Los Angeles.

—. 2009. "What Makes Strong Federalism Work? Fiscal Resources and PresidentialProvincial Relations in Argentina." Publius: The Journal of Federalism 39:1-26.

Besley, Timothy and Stephen Coate. 2002. "Centralized versus decentralized provision of local public goods: a political economy approach." Journal of Public Economics 87:2611-2637.

Binner, Hermes and Antonio Bonfatti. 2008. "Plan Estrategico Provincial Santa Fe: Cinco regiones, una sola provincia." Pp. 297, edited by S. d. R. Ministerio de Gobierno y Reforma del Estado de la Provincia de Santa Fe, Municipios y Comunas. Santa Fe Capital: Gobierno de Santa Fe.

Bird, R. 1992a. "Tax reform in Latin America: A review of some recent experiments." Latin American Research Review 27. 
-. 1992b. "Tax reform in Latin America: A review of some recent experiments." Latin American Research Review 27.

Bird, R. and O. Oliver. 1968. "Tax research and tax reform in Latin America-A survey and commentary." Latin American Research Review 3:5-23.

Bird, Richard Miller. 1992c. Tax policy and economic development Baltimore, MD Johns Hopkins University Press.

Birdsall, Nancy, Augusto De La Torre, and Rachel Menezes. 2007. Fair Growth: Economic Policies for Latin America's Poor and Middle-Income Majority. Washington, D.C.: Center for Global Development.

Blair, John P. 1995. Local Economic Development: Analysis and Practice Sage Publications, Inc

Blakely, E. and T. Bradshaw. 2002. Planning local economic development: theory and practice: Sage Publications.

Boisier, S. 2004. "Desarrollo territorial y descentralización: el desarrollo en el lugar y en las manos de la gente." Eure (Santiago) 30.

Bonvecchi, Alejandro. 2010. "The Political Economy of Fiscal Reform in Latin America: The Case of Argentina." Pp. 121, IDB Working Paper Series No. IDB-WP-175. Washington, D.C.

Brachet-Marquez, Viviane. 2002. "Elementos para investigar la capacidad estatal politico-administrativa en materia de salud publica. Los casos de Guanajuato, Oaxaca y Sonora." Estudios Sociologicos 20:239-252.

Bradhan, P. and D. Mookherjee. 1998. "Expenditure Decentralization and the Delivery of Public Services in Developing Countries." in CIDER Working Paper No. C98104. Berkeley, California: Center for International and Development Economics Research.

Braun, Miguel and Mariano Tommasi 2002. "Fiscal Rules for Subnational Governments: Some organizing principles and Latin American experiences." in IMF/World Bank Conference Rules-Based Fiscal Policy in Emerging Market Economies Oaxaca, Mexico. 
Breslin, Patrick. 1987. Development and Dignity: First Fifteen Years of the Development Assistance. Arlington The Inter-American Foundation.

Brown, Miguel, Luciana Díaz Frers, and Jinu Maria Koola 2006. "Developing a Congressional Caucus to Promote Fiscal Reforms in Argentina." CIPPEC and CIPE, Washington, D.C.

Bruno, A. V. and T. T. Tyebjee. 1982. "The environment for entrepreneurship." Pp. 288315 in Enclyclopedia of Entrepreneurship. Englewood Cliffs, NJ:: Prentice-Hall, Inc.

Cabrera Castellanos, Luis and Edgar Cruz Mora. 2009. "Un Sistema de Ingresos Representativo para los Municipios de México." in MPRA Paper Munich, Germany

Cabrero, Enrique. 2000. "La municipalización, un proceso necesario ante un federalismo que se renueva"." Municipalización en Guanajuato, una estrategia para el fortalecimiento municipal, México UAM/Codereg/Gobierno del Estado de Guanajuato/Dirección General de Fortalecimiento Municipal.

Cabrero, Enrique and Ady Carrera. 2002. "Fiscal Decentralisation and Institutional Constraints. Paradoxes of the Mexican Case." Pp. 45 in Working Paper. Mexico: DAP-CIDE.

Campbell, Tim. 2003. The quiet revolution: decentralization and the rise of political participation in Latin American cities. Pittsburgh: University of Pittsburgh Press.

Cañas García, Alberto. 2011. "Descentralización del gasto y decisiones estatales de inversión en México." proposal Thesis, Departamento de Administracion Publica, Centro de Investigación y Docencia Económicas (CIDE) Mexico City.

Castellanos, Fuente. 2006. "Ricardo Peirone criticó duro a Omar Perotti." in Avizora. Rafaela: Antojo Periodismo Para Pensar.

Cetrángolo, O and J. Gómez-Sabaini. 2007. "La tributación directa en America Latina y los desafíos a la imposición sobre la renta." United Nations, Santiago, Chile.

Cetrángolo O. and J.P Jiménez. 2003. "Política fiscal en Argentina durante el régimen de convertibilidad " Pp. 79 edited by ILPES. Santiago: CEPAL. 
Cheema, G. Shabbir and Dennis A. Rondinelli. 2007. Decentralizing Governance: Emerging Concepts and Practices (Innovative Governance in the 21st Century). Washington, D.C.: Brookings Institution Press.

CIPPEC. 2008. "Las políticas fiscales en la Argentina: un complejo camino hacia la equidad y la eficiencia." Fundacion CIPPEC, Buenos Aires.

Coelho, F. Dias. 2000. "Consorcios regionais de desenvolvimento: os mercados regionais no Estado do Rio de Janeiro." Santiago de Chile, Comisión Económica para América Latina y el Caribe (CEPAL) LC/R,1982.

Costamagna, P. 2000. "La articulación y las interacciones entre instituciones: la iniciativa de desarrollo económico local de Rafaela, Argentina." Comisión Económica para América Latina y el Caribe (CEPAL) LC/R.2011.

Cravacuore, Daniel. 2002. Innovación en la gestión municipal Buenos Aires, Argentina.: Universidad Nacional de Quilmes, Federación Argentina de Municipio.

Davoodi, H. R. 1998. "Fiscal Decentralization and Economic Growth: A Cross-Country Study." Journal of Urban Economics 43:244-257.

de la Maza, Gonzalo and Rodrigo Villar. 2005. "Espacios públicos de concertación local." Draft presented at the Woodrow Wilson Center conference on "Local Spaces for Democratic Innovation," February 10, 2005 and at the University of Texas at Austin on February 8, 2005. Arlington, VA: Inter-American Foundation.

de Mello, Jr., Luiz R. 2001. "Fiscal Decentralization and Borrowing Costs: The Case of Local Governments." Public Finance Review 108.

de Mello, L. 2000. "Fiscal Decentralization and Intergovernmental Fiscal Relations: A Cross- Country Analysis." World Development Journal 28:365-380.

de Mello, L.R. Jr. . 2008. "Public Finance, Government Spending and Economic Growth: The case of Local Governments." in working paper. University of Kent, UK OECD Development Center.

de Mello, Luiz. 2009. "Latin America's public finances “Governments in Latin America have made enormous progress in improving their fiscal management in recent years. But what are the next steps?" " OECD Observed, Paris. 
de Vries, Jaap, Micaela Schuster, Paul Procee, and Harry Mengers. 2001. "Environmental Management of Small and Medium Sized Cities in Latin America and The Caribbean." in Environment Division, Institute for Housing and Urban Development Studies (IHS), edited by S. D. Department. Washington, D.C.: InterAmerican Development Bank.

Di John, Jonathan. 2006. "The Policy a Economy of Taxation and Tax Reform in Developing Countries." United Nations University World Institute for Development New York.

Diaz-Cayeros, Alberto. 2006. Federalism, Fiscal Authority, and Centralization in Latin America. Cambridge, New York: Cambridge University Press.

Dillinger, William and Steven B. Webb. 1999. "Fiscal Management in Federal Democracies: Argentina and Brazil." SSRN eLibrary.

Eaton, Kent 2004. "The link between Political and Fiscal Decentralization In South America." in Decentralization and Democracy in Latin America Notre Dame Press., vol. 1, edited by M. A. P. and D. J. Samuels. Notre Dame, IN: Notre Dame Press.

Eaton, Kent. 2001. "Decentralisation, Democratisation and Liberalisation: The History of Revenue Sharing in Argentina, 1934-1999." Journal of Latin American Studies 33:1-28.

Eaton, Kent and J. Tyler Dickovick. 2004. "The Politics of Re-Centralization in Argentina and Brazil." Latin American Research Review 39:90-122.

Eaton, Kent. 2002. "Fiscal Policy Making in the Argentine Legislature." Pp. 287-314 in Legislative Politics in Latin America, edited by S. Morgenstern and B. Nacif. United Kingdom: Cambridge University Press.

Ebel, Robert D. and Serdar Yilmaz. 2002. " On Measurement and Impact of Fiscal Decentralization. ." in Policy Research Working Paper. Washington D.C.: The World Bank.

Escobar-Lemmon, Maria. 2001. "Fiscal Decentralization and Federalism in Latin America." Publius 31:23-41 
Falleti, Tulia G. 2005. "A sequential theory of decentralization: Latin American cases in comparative perspective." American Political Science Review 99:327-346.

- 2010. Decentralization and Subnational Politics in Latin America (Cambridge Studies in Comparati). New York, NY: Cambridge University Press.

Farfán-Mares, Gabriel. 2010. "Non-Embedded Autonomy: The Political Economy of Mexico's Rentier State (1918-2010)." Doctorate Thesis, Government, London School of Economics and Political Science, London.

Fein, Monica. 2011. "Festejos por el triunfo del 22 de mayo ", vol. 2011. Rosario, Argentina.

Feiock, Richard C. (Editor). 2004. "Metropolitan Governance: Conflict, Competition, and Cooperation (American Governance and Public Policy)." Washington, D.C.: Georgetown University Press.

Feiock, Richard C. and Kim Jae-Hoon. 2001. "Form of Government, Administrative Organization, and Local Economic Development Policy." Journal of Public Administration Research and Theory: J-PART 11:29-49.

Feiock, Richard C., Moon-Gi Jeong, and Kim Jaehoon. 2003. "Credible Commitment and Council-Manager Government: Implications for Policy Instrument Choices." Public Administration Review 63:616-625.

Feiock, Richard C., M. Jae Moon, and Hyung Jun Park. 2008. "Is the World "Flat" or "Spiky"? Rethinking the Governance Implications of Globalization for Economic Development." Public Administration Review 68:23-35.

Feiock, Richard C., Annette Steinacker, and Hyung Jun Park. 2009. "Institutional Collective Action and Economic Development Joint Ventures." Public Administration Review 69:256-270.

Feiock, Richard and Gregory Cable. 1992. "Need, Institutional Arrangements, and Economic Development Policy." Journal of Public Administration Research and Theory: J-PART 2:387-398. 
Figueras-Zanabria, Victor Manuel. 2006. "The politics of fiscal decentralization in Mexico and the role of state governors." Department of Government, University of Essex, Essex.

Finot, Ivan. 2001. "Latin American statistics on local level taxation." in Working paper. Santiago, Chile: ECLAC.

Flamand, Laura. 2004. "The Vertical Dimension of Government: Democratization and Federalism in Mexico." University of Rochester, Rochester, New York.

—. 2005. "Designing Federalism: A Theory of Self-Sustainable Federal Institutions Federalism and Democracy in Latin America." Journal of Politics 67:1307-1310.

Flores, Lourdes. 2009. "Pierde dinero León al quebrar Metrofinanciera." in Milenio. Nevo Leon, Mexico.

Fukasaku, K. and M. de Mello Jr. 1999. "Fiscal Decentralization in Emerging Economies. ." in Governance Issues. Paris, France: OECD.

Fukasaku, Kiichiro and Luiz R. De Mello. 1998. "Fiscal Decentralisation and Macroeconomic Stability: The Experience of Large Developing and Transition Economies." Pp. 121 - 148 in Democracy, decentralisation and deficits in Latin America, edited by K. Fukasaku and R. Hausmann. Paris, France: Inter-American Development Bank/Development Centre of the Organisation for Economic Cooperation and Development.

Fukasaku, Kiichiro and Ricardo Hausmann. 1998. Democracy, decentralisation and deficits in Latin America. Paris, France: Inter-American Development Bank/Development Centre of the Organisation for Economic Co-operation and Development.

Gallicchio, Enrique and Lucy Winchester. 2003. Territorio local y desarrollo. Experiencias de Chile y Uruguay, Edited by E. SUR. Santiago de Chile.

Gavin, Michael and Ricardo Hausmann. 1998. "Fiscal Performance in Latin America: What Needs to be explained?" Pp. 33 - 64 in Democracy, decentralisation and deficits in Latin America, edited by K. Fukasaku and R. Hausmann. Paris, France: Inter-American Development Bank/Development Centre of the Organisation for Economic Co-operation and Development. 
Gemmell, Norman, Richard Kneller, and Ismael Sanz. 2009. "Fiscal Decentralization and Economic Growth in OECD Countries: Matching Spending with Revenue Decentralization." in Working Paper. Madrid, Spain: Instituto de Estudios Fiscales.

George, Alexander L. and Andrew Bennett. 2005. Case Studies and Theory Development in the Social Sciences. Cambridge, Massachussetts: MIT Press.

Gibson, Edward L. . 2004. Federalism and democracy in Latin America. Baltimore, MD: The John Hopkins University Press.

Glaeser, Edward, Jose Scheinkman, and Andrei Shleifer. 1995. "Economic Growth in Cross Section of Cities." in Working Paper No. 5013. Cambridge, Ma: National Bureau of Economic Research.

Gomez Sabaini, Juan. 2006. "Evolución y Situación Tributaria em América Latina: Una Serie de Temas para la Discusión." in Tributación em América Latina: En Busca de una Nueva Agenda de Reformas, edited by O. Cetrángolo and J. Gomez Sabaini. Santiago: ECLAC, United Nations.

Grindle, M. 2000. Audacious reforms: institutional invention and democracy in Latin America. Baltimore, MD: Johns Hopkins University Press.

Grindle, Marilee S. 2007. Going Local: Decentralization, Democratization and the Promise of Good Governance. Princeton, NJ: Princeton University Press.

Grindle, Merilee S. 1996. Challenging the state: crisis and innovation in Latin America and Africa. New York: Cambridge University Press.

Habibi, Nadir, Cindy Huang, Diego Miranda, Victoria Murillo, Gustav Ranis, Mainak Sarkar, and Frances Stewart. 2001. "Decentralization in Argentina." Pp. 57 in Center Discussion Paper. New Haven, Ct: Economic Growth Center: Yale University.

Haggard, Stephan and Steven B. Webb. 2004. "Political Incentives and Intergovernmental Fiscal Relations: Argentina, Brazil, and Mexico Compared." in Decentralization and Democracy in Latin America, edited by A. P. Montero and D. J. Samuels. Notre Dame, IN: Notre Dame Press. 
Hernandez-Trillo, Fausto and Brenda Jarillo-Rabling. 2008. "Is Local Beautiful? Fiscal Decentralization in Mexico." World Development Journal 36:1547-1558.

Hirschman, Alberto O. 1970. Exit, Voice, and Loyalty: Responses to Declines in Firms, Organizations, and States. Cambridge, MA: Harvard University Press.

Hopkins, Alfred. 2002. "Running out of Patience." in World Press Review Buenos Aires, Argentina.

Hornbeck, J. F. 2002. "The Argentine Financial Crisis: A Chronology of Events." vol. Order Code RS21130, edited by CRS Report for Congress. Washington, DC: Congressional Research Services.

INAFED Instituto para el Federalismo y el Desarrollo Municipal. 2010. "elocal Web site." edited by elocal.gob.mex. Mexico City: SEGOB Secretaría de Gobernación.

Instituto de Investigaciones Económicas. 2011. "Producto Bruto Geográfico Rosario y Aglomerado Gran Rosario Serie 1993-1998." in Escuela de Economía Facultad de Ciencias Economías y Estadística. Rosario: Universidad Nacional De Rosario.

Inter-American Development Bank. 2001. "Making Decentralization Work in Latin America and the Caribbean: A Background paper for the Subnational Development Strategy." edited by S. D. Department. Washington, D.C.: InterAmerican Development Bank.

Joumard, Isabelle, Per Mathis Kongsrud, Young Sook Nam, and Robert Price. 2004. "Enhancing the Effectiveness of Public Spending: Experience in OECD Countries." Organisation for Economic Co-operation and Development, Paris, France.

Joyce, Philip G. and Daniel R. Mullins. 1991. "The Changing Fiscal Structure of the State and Local Public Sector: The Impact of Tax and Expenditure Limitations." Public Administration Review 51:240-253.

Juckett, Karen. 2008. "How can the poor benefit from Trade liberalization? A comparative case study of two exports promotion projects in Bolivia." University of Texas, Austin, Austin, TX. 
Kapstein, Ethan B. 1994. Governing the global economy: international finance and the state. Cambridge, Mass.: Harvard University Press.

Kaufman, R. and J. Nelson Nelson. 2004. Crucial Needs: Weak Incentives: Social Sector Reform, Democratization, and Globalization in Latin America. Washington, D.C.: Woodrow Wilson Center Press. .

King, Gary, Robert O. Keohane, and Sidney Verba. 1994. Designing Social Inquiry. Princeton, New Jersey: Princeton University Press.

Kliksberg, Bernardo. 2004. "Hacia un nuevo perfil del Estado y el servicio civil: los cambios en las percepciones y las demandas de los latinoamericanos." Pp. 20 in IX Congreso Internacional del CLAD sobre la Reforma del Estado y de la Administración Pública. Madrid, Spain: Centro Latinoamericano de Administración para el Desarrollo.

-. 2005. "Public administration in Latin America: promises, frustrations and new examinations." International Review of Administrative Sciences 7:309-326.

Koethenbuerger, Marko. 2007. "Federal tax-transfer policy and intergovernmental precommitment. ." Regional Science and Urban Economics 38:16-31.

Kuwayama, Mikio, Ueki Yasushi, and Masatsugu Tsuji. 2005. "Information Technology for Development of Small and Medium-sized Exporters in Latin America and East Asia." Santiago, Chile: Economic Commission for Latin America and the Caribbean (ECLAC).

Kwon, Myungjung, Frances S. Berry, and Richard C. Feiock. 2009. "Understanding the Adoption and Timing of Economic Development Strategies in US Cities Using Innovation and Institutional Analysis." Journal of Public Administration Research and Theory: J-PART 19:967-988.

Ladd, Helen F. and John Yinger. 1989. American's Ailing Cities: Fiscal Health and design of Urban Policy. . Baltimore: MD: The John Hopkins University Press.

Leon, City of. 2009. "Primer Informe de Gobierno (2009-2012): Presidente Muncipal Ricardo Sheffild Padilla." Pp. 46, vol. 1. Leon, Guanajuato. 
Leonardi, Agustina and Adriano Mandolesi. 2010. "Asignación de Fondos Nacionales a Provincias." Fundacion Libertad and Instituto de Estudios Economicos, Rosario, Argentina.

Levy, Santiago. 2008a. Good Intentions, Bad Outcomes: Social Policy, Informality, and Economic Growth in Mexico. Washington, D.C.: Brookings Institution Press.

Levy, Santiago and Michael Walton. 2009. "No growth without equity? Inequality, Interests, and Competition in Mexico." Pp. 476 in Equity and Development Series. Washington, D.C.: Palgrave Macmillan/The International Bank for Reconstruction and Development - The World Bank.

Litvack, J. and J. Seddon. 1998. "Decentralization briefing notes." in Working paper. Washington, D.C.: World Bank Institute.

Liu, Chih-hung. 2007. "What type of Fiscal Decentralization System has Better Performance?" Dissertation Thesis, School of Public Policy, University of Maryland, College Park.

Lora, Eduardo. 2008. "El futuro de los pactos fiscales en América Latina." Washington, D.C.: Banco Interamericano de Desarrollo

Mahon, James E. 1997. "Tax Reform and its Determinants in Latin America, 1977-94: Implications for Theories of State Development." Pp. 14 in Latin American Studies Association. Continental Plaza Hotel, Guadalajara, Mexico.

—. 2009. "Tax Reforms and Income Distribution in Latin America." Pp. 42 in XXVIII Congress of the Latin American Studies Association. Rio de Janeiro.

Malizia, Emil and Edward Feser. 1999. Understanding Local Economic Development Center for Urban Policy Research.

Manor, James. 1999. The Political Economy of Democratic Decentralization (Directions in Development) Washington, D.C.: World Bank Publications.

Marsiglia, Javier and Graciela Pintos. 1999. "La construcción del desarrollo local como desafío metodológico." in Desarrollo local en la globalización, edited by J. Marsiglia. Montevideo: CLAEH. 
Martínez Pellégrini, Sárah, Laura Flamand, and Alberto Hernández. 2008. "Panorama del desarrollo municipal en México: Antecedentes, diseño y hallazgos del Índice de Desarrollo Municipal Básico." Gestión y Políticias Públicas XVII:145-192.

Martinez-Vazquez, Jorge. 2008. "Evaluating a Tax System: Mexico." Pp. 189-231 in Public Finance for Poverty Reduction: Concepts and Case Studies from Africa and Latin America, edited by B. Moreno-Dodson and Q. Wodon. Washington, D.C.: The World Bank.

Martinez-Vazquez, Jorge and Robert McNab. 1997. " Fiscal Decentralization, Economic Growth and Democratic Governance." in Working Paper. Atlanta, Georgia: Georgia State University Andrew Young School of Policy Studies.

Melamud, Ariel. 2010. "Reglas fiscales en Argentina: el caso de la ley de responsabilidad fiscal y los programas de asistencia financiera." Pp. 55, vol. 71, edited by Instituto Latinoamerica y del Caribe de Planificacion Economica y Social (ILPES). Santiago, Chile: Gestion Publica, CEPAL.

Melo, Marcus André. 2007. "Institutional Weakness and the Puzzle of Argentina's Low Taxation." Latin American Politics and Society 49:115-148.

Merino Huerta, Mauricio. 1991. Fuera del centro. Xalapa, Veracruz: Universidad Veracruzana.

—. 2008. "Federalismo vs. Municipalismo: Una hipótesis alternativa al programa de investigación sobre la materia." Pp. 30. Guadalajara: Programa de Naciones Unidas para el Desarrollo (PNUD).

Montero, A. 2001. "After decentralization, patterns of inter-governmental conflict in Argentina, Brazil, Spain and Mexico." Publius: The Journal of Federalism 31:4366.

Montero, Alfred and David Samuels. 2004. "Decentralization and Democracy in Latin America." in The Helen Kellogg Institute for International Studies,. Notre Dame, IN: Notre Dame Press.

Moore, Mick. 2007. "How Does Taxation Affect the Quality of Governance?" Institute of Development Studies, University of Sussex, Brighton, United Kingdom. 
Moreno, Carlos. 2004. "Fiscal Performance of Local Governemtns in Mexico Under Decentralization: A Political Examination." in 2004 Meeting of Latin American Studies Association. Las Vegas, Nevada.

Municipalidad de Rafaela. 2008. "Relevamiento Socioeconomico Rafaela 2008." Pp. 48, edited by Instituto de Capacitacion y Estudios para el Desarrollo Local. Rafaela: Municipalidad de Rafaela.

Narayan, Deepa and Patti Patesch. 2002. "Voices of the Poor: From Many Lands." Washington DC: World Bank Publication.

Nickson, R. Andrew. 1995. Local Governments in Latin America. Boulder: Lynn Rienner Publishers, Inc.

Oates, W. 1999. " An essay on fiscal federalism." Journal of Economic Literature $37: 1120-49$.

OECD. 2007. "Web site on fiscal federalism." http://www.oecd.org/department/0,3355,en_2649_22054704_1_1_1_1_1,00.html Paris: France: Organization for Economic Co-Operation and Development.

Ortiz Pinchetti, Francisco and Francisco Ortiz Pardo. 2001. El Fenomeno Fox: La historia que Proceso censuro. Mexico City: Editorial Planeta Mexicana.

Pagano, Michael A. and Ann O’M. Bowman. 1995. Cityscapes and Capital: The Politics of Urban Development. Baltimore, MD: John Hopkins Press.

Perry, G., S. Javed Burki, and W. Dillinger. 1999. Beyond the Center: Decentralizing the State Washington, D.C.: The World Bank.

Peterson, Paul. 1995. The Price of Federalism. Washington, D.C.: Brookings Institution Press.

Peterson, Paul E. 1981. City Limits. Chicago, Il: University Of Chicago Press.

Porter, Michael E. 1990. The Competitive Advantage of Nations. New York: The Free Press. 
Prud'homme, Rémy. 1995. "The Dangers of Decentralization." Pp. 201-220 in Research Observer, vol. 10. Washington, D.C.: The World Bank

Raich, Uri. 2002. "Impacts of Expediture Decentralization on Mexican Local Governments." Pp. 44. Mexico City: Budget and Public Expenditure Program at the Centre of Research and Teaching of Economics (CIDE).

Roberts, Bryan R. 2005. "Globalization and Latin American Cities." International Journal of Urban and Regional Research 29:110-123.

Rodden, Jonathan. 2002. "The Dilemma of Fiscal Federalism: Grants and Fiscal Performance around the World." American Journal of Political Science 46:670687.

-. 2004. "Comparative Federalism and Decentralization: On meaning and Measurement." Comparative Politics 36:481-500.

Rodriguez, Victoria. 1997. Decentralization in Mexico: from Reforma Muncipal to Solidaridad to Nuevo Federalismo. Boulder: Westview Press.

Rondinelli, D. and G. Shabbir Cheema. 1981. "Government decentralization in a comparative perspective: Theory and practice in developing countries." International Review of Administrative Sciences 47:133-45.

Rondinelli, Dennis A. and G. Shabbir Cheema. 2003. Reinventing government for the twenty-first century: state capacity in a globalizing society. Bloomfield, CT Kumarian Press.

Rosario, City of. 2011. "Sistema de Informacion para el Desarrollo." vol. 2011, edited by O.E. Development. Rosario.

Rosenbaum, A. 1997. "Democracy, Governance and Decentralization." in United Nations Conference on New and Restored Democracies. Bucharest, Romania,.

Rosenbaum, A. and C. Rodriguez Acosta. 2008. "Metropolitan Governments in Latin America." in Improving Local Government: Outcomes of Comparative Research edited by M. De Vries, P. Reddy, and M. Samsul Haque. New York, NY: Palgrave Macmillan. 
Rueschemeyer, D. and J. Stephens. 1997. "Comparing Historical Sequences: A Powerful Tool for Causal Analysis." Comparative Social Research 16:55-72.

Santín, L. 2004. "Decentralization and civil society in Mexico." Pp. 75-114 in Decentralization, democratic governance, and civil society in comparative perspective: Africa, Asia, and Latin America, edited by P. Oxhorn, J. Tulchin, and A. Selee. Baltimore: MD: Johns Hopkins University Press.

Santiso, Carlos. 2005. "Budget Institutions and Fiscal Responsibility: Parliaments and the Political Economy of the Budgetary Process in Latin America." in XVII Regional Seminar on Fiscal Policy. Santiado de Chile, Chile: United Nations Economic Commission for Latin America and the Caribbean (ECLAC).

Schneider, Aaron. 2003. "Who Gets What from Whom? The Impact of Decentralization on Tax capacity and Pro-Poor Policy." Institute of Development Studies, Paris, France.

Schumpeter, Joseph A. 1918. "The Crisis of the Tax State." Pp. 99-140 in Joseph A. Schumpeter. The Economics and Sociology of Capitalism, edited by R. Swedberg. Princeton, New Jersey: Princeton University Press.

—. 1948. "Wage and Tax Policy in Transitional States of Society." Pp. 429-437 in Joseph A. Schumpeter. The Economics and Sociology of Capitalism, edited by R. Swedberg. Princeton, New Jersey: Princeton University Press.

SEGOB. 2008. "Manual de Transferencias Federales para Municipios." Pp. 175, edited by S. d. Gobernacion. Mexico City: Instituto National para el Federalismo y el Desarollo Muncipal.

Selee, A. 2006. "The paradox of Local Empowerment: Decentralization and Democratic Governance in Mexico." Maryland School of Public Policy, University of Maryland, College Park.

Smoke, Paul. 2005. "Fiscal Decentralization and Good Governance." Decentralized Governance, edited by P. A. a. D. M. D. Department for Economic and Social Affairs. New York: United Nations

Smoke, Paul Smoke, Eduardo J. Gómez, and George E. Peterson. 2006. "Decentralization in Asia and Latin America :towards a comparative interdisciplinary perspective." Northampton, MA: Edward Elgar Publishing, Inc. 
Sour, Laura. 2004. "El sistema de transferencias federales en Mexico ¿Premio o castigo para el esfuerzo fiscal de los gobiernos locales urbanos?" Gestión y Políticias Públicas XIII.

-. 2008. "Un Prepaso de los Conceptos sobre Capacidad y Esfuerzo fiscal, y su Aplicacion en los Gobiernos Locales Mexicanos." Estudios Demograficos y Urbanos 23.

Sour, Laura, Irma Ortega, and Sergio San Sebastián. 2003. "¿Quién tiene la última palabra sobre el gasto público en México?" Programa de Presupuesto y Gasto Público / Centro de Investigación y Docencia Económicas, CIDE, Mexico City.

Stein, Ernesto. 1998. "Fiscal Decentralisation and Government Size in Latin America." Pp. 95 - 119 in Democracy, decentralisation and deficits in Latin America, edited by K. Fukasaku and R. Hausmann. Paris, France: Inter-American Development Bank/Development Centre of the Organisation for Economic Co-operation and Development.

—. 1999a. "Fiscal Decentralization and Government Size in Latin America." Journal of Applied Economics 2:357-391.

—. 1999b. "Reglas Macro - Fiscales e Instituciones Presupuestarias." vol. 2002: Centro de Capacitacion y Estudios, Ministerio de Economia - Argentina.

Stein, Ernesto, Mariano Tommasi, Koldo Echebarria, Eduardo Lora, and Mark Payne. 2006. "The Politics of Policies: Economic and Social Progress in Latin America." Pp. 290. Washington, D.C.: Inter-American Development Bank, David Rockefeller Center for Latin American Studies, Harvard University.

Tamayo-Flores, Rafael and Fausto Hernández-Trillo. 2006. "Financiamiento de la Infraestructura Local en México: Temas Actuales y Perspectivas." in Working paper Mexico City, Mexico: CIDE y Tecnológico de Monterrey.

Tanzi, V. 2000. "On Fiscal Federalism: Issues to Worry About." an IMF Report.

Tanzi, Vito. 1969. The individual income tax and economic growth: an international comparison: France, Germany, Italy, Japan, United Kingdom, United States. Baltimore, Maryland: Johns Hopkins Press. 
Tendler, Judith 1997. Good Government in the Tropics, Edited by S. i. Development. Baltimore: The Johns Hopkins University Press.

The City of Leon. 2009. "Inhabilitan a Ex Tesorero." vol. 2011. Leon, Mexico.

Tommasi, M. 2002. "Federalism in Argentina and the Reforms of the 1990s." Buenos Aires: Universidad de San Andrés - Departamento de Economía.

Tommasi, M., S. Saiegh, and P. Sanguinetti. 2001. "Fiscal Federalism in Argentina: Policies, Politics, and Institutional Reform." Economia:147-201.

Treisman, Daniel. 2007. The Architecture of Government: Rethinking Political Decentralization (Cambridge Studies in Comparative Politics). London: Cambridge University Press.

Tulchin, J. and A. Selee. 2004. Decentralization and democratic governance In Latin America. Washington, D.C.: Woodrow Wilson Center for Scholar.

U.S. Department of State. 2011. "Background Note: Argentina." vol. 2011, edited by Bureau of Western Hemisphere Affairs. Washington, DC.

UN-Habitat. 2006. "Urbanization Facts and Figures." Pp. 4, vol. World Urban Forum III An international UN-Habitat Event on Urban Sustainablity. Vancouver, Canada: UN Habitat.

Uña, Gerardo. 2007. "Fondos Fiduciarios en la Argentina: Los "todo terreno" de la política económica." CIPPEC, Buenos Aires.

United Citeis and Local Governments (UCLG ). 2010. "Local Government Finance: The Callenges of the 21st Century." Second Global Report on Decentralizaiton and Local Democracy. Barcelona: United Cities and Local Governments (UCLG).

Vázquez Barquero, A. . 2000. "Desarrollo económico local y descentralización: aproximación a un marco conceptual." Economic Commission for Latin America and the Caribbean (ECLAC).

Vázquez Barquero, Antonio. 1999. "El desarrollo local en los tiempos de globalización." Revista Ciudad y Territorio. Estudios Territoriales XXXI. 
—. 2000. "Desarrollo Económico Local y Descentralización: Aproximación a un marco conceptual." Santiago de Chile.

Watts, Ronald L. 2008. Comparing Federal System, Third Edition, Edited by Institute of Intergovernmental Relations. Montreal Canada: McGill-Queen's University Press.

Weingast, B. 1995. The Economist Role in Political Institutions Market Preserving Federalism and Economic Development. London, England: Oxford University Press.

—. 2006. "Second generation fiscal federalism: implications for decentralization democratic governance and economic development." in Commissioned paper. Washington, D.C.: ARD, inc and USAID.

Wibbels, E. 2005. Federalism and the Market: Intergovernmental Conflict and Economic Reform in the Developing World. Cambridge: Cambridge University Press.

Wiesner, E. 2003. Fiscal federalism in Latin America: From entitlements to markets. Washington, D.C.: Inter-American Development Bank.

Williamson, John. 1990. "What Washington Means by Policy Reform." in Latin American Adjustment: How Much Has Happened?, edited by J. Williamson. Washington, D.C.: Institute of International Economics.

Willis, E., CB. Garman, S. Haggard,. 1999. "The Politics of decentralization in Latin America." Latin American Research Review 34:7-56.

Wolman, Harold and David Spitzley. 1996. "The Politics of Local Economic Development." Economic Development Quarterly 10:115-150

World Bank. 2007. "Local Economic Development Web site ".

—. 2009. "Doing Business report Latin America." World Bank, Washington, D.C.

Ziccardi, Alicia. 1998. Gobernabilidad y participación ciudadana en la ciudad capital. Mexico City: Miguel Ángel Porrúa / Instituto de Investigaciones Sociales, Universidad Autónoma de México (IISUNAM). 
APPENDICES 
Appendix 1 - Interview Guide for Semi-Structured Interviews 


\section{Guía de Entrevista para Autoridades Municipales \\ Questionnaire for Interviews of Municipal Officials}

N.B. Esta encuesta se aplicará en una entrevista semi-estructurada, es decir, las preguntas se harán por medio de una conversación, asegurando que se incluya cada pregunta. Esperamos recibir respuestas generales mas que datos precisos.

Note: This questionnaire will be applied as a semi-guided interview, that is, the questions will be asked in the context of a conversation, making sure to include each of these questions. We expect to receive open-ended answers rather than specific data.

1. ¿Cuáles han sido los mayores retos del muncipio en su área durante su gestión? ¿En cuáles problemas municipales ha enfocado sus mayores esfuerzos?

What are (were) the greatest challenges the municipal government during your period? In what areas have you (did you) focus most of your efforts?

2. ¿Cómo han evolucionado las finanzas del municipio durante su gestión? How have (did) the finances of the municipal government evolve during your period?

3. ¿Qué tipo de programas de desarrollo local han sido implementados o discutidos en los últimos diez años?

In the past 10 years, what types of development programs have (been) implemented or discusses for the municipality?

4. Explique/Describa cuál es su percepción sobre cómo se ha desarrollado (o cómo ha sido el crecimiento del municipio) el municipio en los últimos diez años.

Describe your perceptions of how the municipality has development in the past ten years.

5. ¿Podría decirnos como evalúa el nivel de autonomía de su municipio en términos de autonomía administrativa, política y fiscal?

Describe your perceptions of municipal autonomy in regards to administrative, political and fiscal control. 
Appendix 2 - Cover Letter and Survey Instrument 


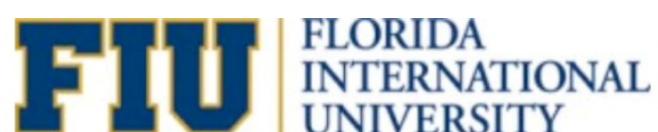

\section{CONSENT TO PARTICIPATE IN THE RESEARCH STUDY}

You are being asked to participate in a research study. The principal investigator is Ms. Heidi Jane Smith, a Doctoral Candidate in Public Management at Florida International University, who is conducting a study concerning local governments in Latin America. More specifically, the investigator is interested in analyzing the effects of fiscal decentralization on the promotion of economic development in Latin America.

You are invited to participate in a face-to-face interview of about 30 minutes. The investigator will contact you to arrange a convenient time to meet. The participants for the study were selected among the following categories: city mayors, municipal treasurers, budget directors, planning directors and other related grassroots organization representatives working with the local governments in select cities in Argentina and Mexico. The interview will be tape-recorded and the investigator may take written notes in order to capture your answers accurately.

It is not expected that you will be harmed by participating in the study. If you feel uncomfortable during the interview you may take a break or you may withdraw from it at anytime. Your participation is considered voluntary and you will not get any direct benefits from being in the study. Your consent is given once you decide to participate in the interview. Your participation in this research is voluntary, and you will not be penalized or lose benefits if you refuse to participate or decide to stop. Can I continue?

Your participation would be extremely valuable to the present research, as well as to the policy formulation for Latin America. Your answers will be kept completely confidential. Your opinion will be compared to the opinions of other subjects and the results will be reported as a group aggregate. If you choose not to participate, no other action is required.

Should you need more information about this research before or after completing the interview, you may contact Dr. Allan Rosenbaum or Ms. Heidi Jane Smith at 305-348-1271 or 202-2712546. In case you have any questions regarding your rights as a participant in this research study you may contact Dr. Patricia Price, the Chairperson of the FIU Institutional Review Board at 305-348-2618 or 305-348-2494. Thank you very much for your time and cooperation! 


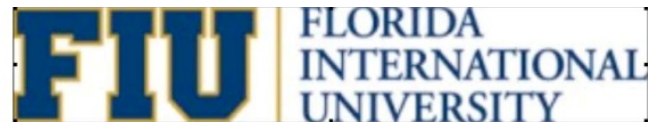

\section{CONSENTIMIENTO DE PARTICIPAR EN UN ESTUDIO DE INVESTIGACIÓN}

Usted ha sido seleccionado para participar en un estudio de investigación. El investigador principal es la Sra. Heidi Jane Smith, candidato a doctorado en gestión pública de la Universidad Internacional de la Florida (FIU), que está llevando a cabo un estudio sobre los gobiernos locales en Latinoamérica. Más concretamente, la investigadora está interesada en analizar los efectos de la descentralización fiscal en la promoción del desarrollo económico en Latinoamérica.

Usted está invitado a participar en una entrevista que se estima unos 30 minutos. La investigadora se comunicará con usted para fijar una hora conveniente para reunirse. Los participantes del estudio fueron seleccionados entre las siguientes categorías: alcaldes, tesoreros municipales, directores de presupuesto, directores de la planificación y otros representantes de organizaciones de base relacionados con los gobiernos locales en ciudades preseleccionadas en Argentina y México. La entrevista será grabada y la investigadora puede tomar notas escritas a fin de captar sus respuestas con la mejor exactitud.

No se espera que usted se verá perjudicado por participar en el estudio. Si se siente incómodo durante la entrevista, se puede tomar un descanso o suspenderlo directamente. Su participación se considera voluntaria y no obtendrá ningún beneficio directo por ser en el estudio. Su aprobación es dado una vez que decidan participar en la entrevista. Su participación en esta investigación es voluntaria, y usted no será penalizado o perderá beneficios si se niegan a participar o decide dejar. ¿Puedo continuar?

Su participación sería muy valiosa para la presente investigación, así como a la formulación de políticas para América Latina. Sus respuestas serán mantenidas totalmente confidenciales. Su opinión será comparada con las opiniones de otros temas y los resultados serán divulgados como un agregado al grupo. Si usted decide no participar, ninguna otra acción es necesaria.

Si necesita más información sobre esta investigación, antes o después de terminar la entrevista, puede comunicarse con el Dr. Allan Rosenbaum o la Sra. Heidi Jane Smith al 305-348-1271 o 202-271-2546. En caso de tener alguna pregunta sobre tus derechos como participante en este estudio de investigación puede comunicarse con la Dra. Patricia Price, la Directora de la Institutional Review Board en el FIU, al 305-348-2618 o 305-348-2494. ¡Muchas gracias por su tiempo y cooperación! 


\section{Autonomia Fiscal}

* 1. ¿Podría decirnos como evalúa el nivel de autonomía de su municipio? (Marque con una $X$ de acuerdo a la realidad de su municipio)

1. Autonomía política (Toma de decisiones, orgánica interna y similares)
2. Autonomía administrativa (Capacidad de definir la planta de funcionarios
municipales, procedimientos de compras y similares)
3. Autonomía presupuestaria (Definición del presupuesto, creación o supresión de
impuestos, etc.)

* 2. Podría Ud. especificar los siguientes datos sobre el desarrollo económico de su municipio (anote el número correspondiente a cada casillero)

1. Emprendimientos (negocios/SMEs) registrados y operando en su municipio (industrias, comercio, actividades de servicios)

2. Emprendimientos registrados el último año en su municipio

3. Número de organizaciones, agrupaciones o cámaras empresariales o de microempresarios actuando en su municipio

3. Podría indicar cuánto tiempo se toma (en promedio) para formalizar una empresa en su municipio (anote Tiempo (promedio en días):

4. De la siguiente lista de iniciativas nos interesaría saber cuáles se están llevando a cabo en su municipio (marque con una $X$ las opciones que correspondan):

2. El municipio organiza al menos una feria anual de promoción de los productos locales.

3. Existe un premio o reconocimiento anual a los mejores emprendimientos o empresarios

4. El municipio dispone de un catastro actualizado de los microemprendimientos locales.

5. El gobierno local dispone de información sobre las condiciones del entorno para el desarrollo de emprendimientos: accesos, caminos, infraestructura productiva y otros.

6. El gobierno local dispone de una ventanilla única para iniciar actividades comerciales, industriales o emprendimientos.

7. El municipio tiene un mecanismo formal de vinculación con los empresarios locales

8. El municipio ha desarrollado un programa de apoyo a los microempresarios locales.

9. El municipio está en constante actualización del registro de patentes comerciales y actividades productivas del territorio.

10. El municipio es receptor de cooperación internacional

11. El municipio tiene alianzas para el desarrollo local: ciudades hermanas, asociación con universidades locales, corporación de desarrollo local.

12. El municipio es miembro de una asociación intermunicipal para el desarrollo local.

13. El municipio administra un programa de crédito para la micro y pequeña empresa

14. Otros (especificar)

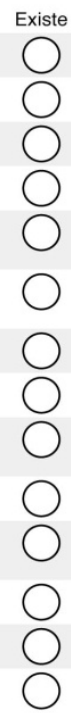


5. Podría señalar en forma agregada a cuánto asciende el presupuesto de ingresos de su municipio para este año (anote)

Total ingresos municipales en dólares USA (aprox.) (US\$)

* 6. ¿Podría explicarnos cómo están compuestos los ingresos municipales en el presupuesto de su municipio? (Anote el porcentaje aproximado y fijese que sume $100 \%)$

1. Recursos Propios: IMPUESTOS LOCALES (Patentes municipales y/o comerciales e industriales, patentes o impuesto a vehículos motorizados, impuesto de bienes raices)

2. Recursos Propios: DERECHOS Y COBROS (Derechos por permisos de propaganda, derechos de aseo domiciliario, derechos por otros servicios)

3. Recursos Propios: MULTAS, INGRESOS DE CAPITAL

4. Transferencias del gobierno central y fondos de coparticipación

5. Donaciones de organismos de cooperación internacional

6. Préstamos de instituciones financieras internacionales

7. Respecto al manejo de las finanzas municipales, podría señalar lo que corresponda a su municipio (marque con una $X$ ):

1. Capacidad de endeudamiento, ya sea directo bancario o vía emisión de bonos.

2. Posibilidad de definir tasas o alícuotas propias, para los impuestos que se aplican en su municipio (bienes raíces, patentes o permisos comerciales)

3. Colocar saldos de caja o activos financieros en el sistema de colocaciones bancario. 


\section{Temas Demográficos}

PARA TERMINAR EL CUESTIONARIO, LE AGRADECEMOS COMPLETAR LA SIGUIENTE INFORMACIÓN

\section{El lugar y país del cual proviene}

Ciudad/Pueblo:

Estado/Prov.:

Código Postal:

País:

Dirección de correo

electrónico:

\section{Tamaño de su municipio en términos de población}

1. Menos de 20.000 habitantes

2. Entre 20.000 y 50.000 habitantes

3. Entre 50.000 y 100.000 habitantes

4. Entre 100.000 y 1.000 .000 de habitantes

5. Más de 1.000 .000 de habitantes

\section{Lugar de la administración territorial}
___. Capital nacional
2. Capital estadual, provincial o regional
3. 3. Ciudad
4. Pueblo

\section{Nivel de pobreza de su municipio}
1. Menos de un $10 \%$ de la población
2. Entre un 10 y un $25 \%$ de la población
3. Entre un 25 y un $50 \%$ de la población
4. Entre un 50 y un $75 \%$ de la población
5. Más de un $75 \%$ de la población 


\section{Indique cuál es el cargo que Ud. desempeña}

1. Alcalde, Prefecto u Intendente
2. Presidente del Consejo Municipal, Concejal, Edil, Consejero Municipal u otra autoridad local electa
3. Ejecutivo, profesional o funcionario municipal
4. Otro

\section{Años de desempeño en el cargo actual (escríbalo)}

\section{Género}

Hombre

Mujer

\section{Edad (registre su edad)}

9. Nivel educacional (registre su nivel de instrucción)
_. Educación primaria
2. Educación secundaria
3. Estudios universitarios incompletos
4. Estudios universitarios completos
5. Estudios universitarios de postgrado 


\section{Electronic Survey For the Latin American Municipal Associations English Version}

1. Please evaluate the level of autonomy your municipality has (mark an $\mathbf{X}$ appropriately)?

\begin{tabular}{l|l|l|l|l} 
& High & Significant & Insignificant & $\begin{array}{l}\text { Don't } \\
\text { know/or } \\
\text { not related }\end{array}$ \\
\hline $\begin{array}{l}\text { 1. Political Autonomy } \\
\text { (Level of decision making, originating internally) }\end{array}$ & & & & \\
\hline $\begin{array}{l}\text { 2. Administrative Autonomy } \\
\text { (Capacity to define municipal authorities, processes, } \\
\text { and purchases) }\end{array}$ & & & & \\
\hline $\begin{array}{l}\text { 3. Budget Autonomy } \\
\text { (Defined budget, creating and calculating taxes and } \\
\text { expenses) }\end{array}$ & & & & \\
\hline
\end{tabular}

2. Can you specify the number of the following agents of Local Economic Development?

1. Registered Small Business and operations in your municipality (industry, commerce, and service activities)

2. Number of Registered small business in the last year

3. Number of civil society organizations, micro-businesses, associations, groups that are in your municipality

3. Could you please indicate the time that it takes to set up a business?

Time (estimated in days)

4. Please explain the composition of total inputs to your municipal budget. (Note in approx. percentage that totals 100 ).

Source

1.Resources: LOCAL TAXES

(Municipal tax on industry, commerce, motor vehicles, property taxes)

2.Own Resources: RIGHTS and

(Right to commercialize, access to addressees and other services)

3. Own Resources: FINES, CAPTIAL PAYMENTS

4. Central Government Transfers and Intergovernmental payments

5. International Cooperation Donations

6. Public loans from financial institutions

TOTAL

Number (approx.)

5. Can you indicate how much was your public budget in 2007? (Approximate in US\$)

6. In respect to your municipal finances, please indicate which applies:

1. The capacity to become in debt, that the bank will loan directly or through the emission of municipal bond.

2 . We have the possibility to define tax rates, schedules and plans that will be applied to the municipality (property taxes, licenses and commercial fees)

3. We have active financial rigors and systems and use bank savings accounts

7. Please indicate the interest in the following:

\begin{tabular}{l|l} 
& Yes, we have \\
\hline 1. The municipality has a local economic development promotional office & \\
\hline 2. The municipality organizes annual fairs and carnivals to advertise local products & \\
\hline 3. There are prizes and annual acknowledgement of best business and entrepreneurs &
\end{tabular} 
4. The municipality has up-to-date maps and locations of local businesses

5. The local government is open to free access of information to open businesses: access, roads, and productive infrastructure, among other things?

6 . The local government has one-window to set up business activities, commercial and industrial licensing?

7. The municipality has formal connections to the local business community

8. The municipality has developed support programs for new small business leaders?

9. The municipality has an updated plan of registered commercial plants and productivity activities in your area?

10. The municipality receives of international cooperation?

11. The municipality has partnerships with local organizations: city sisters, with local universities, international cooperation agencies

12. The municipality is a member of an inter- municipal association for economic development

13. The municipality administers a micro-credit plan for small and medium size businesses

14. Other (specify)

8. What are the following instruments that are disposable in your municipality

\begin{tabular}{l|l|l|l} 
& $\begin{array}{l}\text { Yes, we } \\
\text { have it }\end{array}$ & $\begin{array}{l}\text { Elaborated } \\
\text { This year }\end{array}$ & Elaborated last year \\
\hline Local Development Plan & & & \\
\hline Fiscal Investment Plan & & & \\
\hline Urban Planning and Regulations & & & \\
\hline Education, Health and Social Plans & & & \\
\hline Municipal Budget & & & \\
\hline Rules, Manuals and Policy Procedures & & & \\
\hline Personal Capacity Plan & & & \\
\hline Municipal taxes and collection system & & &
\end{tabular}

DEMOGRAPHIC INFORMATION (please put an $\mathrm{X}$ where it applies)

9. Your country

10. The population of your municipality

1. Less than 20,000 habitants

2. Between 20,000 to 50,000

3. Between 50,000 to 100,000

4. Between 100,000 and $1,000,000$

5. More than 1,000,000 habitants

11. The Administrative Territory

a. National Capital

b. State, provincial or Regional Capital

c. City

d. Town

12. The level of poverty in your municipality

- Less than $10 \%$ are poor

- Between 10-25\% are poor

- Between 25-50\% are poor

- Between 50-75\% are poor

- More than $75 \%$ are poor

13. The job you hold

- Mayor, president of the municipal council

- Councilor, other elected official 
- Executive or profession in the municipal government

- Other (specify)

14. The number of years you have had held it?

15. Your gender

Man

Women

16. Your age

17. Your level of education
a. Primary school completed
b. Secondary school completed
c. University studies (incomplete)
d. University studies completed
e. Post-Graduate studies 
Appendix 3 - Argentina and Mexico Federations Compared 


\begin{tabular}{|l|l|l|}
\hline Shares of Local Own-source Revenues (in percentages) \\
\hline Country & $\begin{array}{l}\text { Own taxes and } \\
\text { fees as \% of local } \\
\text { revenues }\end{array}$ & $\begin{array}{l}\text { Local own taxes } \\
\text { as fees as \% of } \\
\text { GDP }\end{array}$ \\
\hline Argentina & $49.8 \%$ & $1.2 \%$ \\
\hline Mexico & $15.6 \%$ & $2.4 \%$ \\
\hline Source: UCLG data Collection \\
\hline
\end{tabular}

\begin{tabular}{|l|l|l|l|}
\hline Authority to Borrow by Local Governments \\
\hline Country & $\begin{array}{l}\text { Access to Financial } \\
\text { Markets }\end{array}$ & Municipal Bank & Limitations \\
\hline Argentina & Yes & Yes & Yes \\
\hline Mexico & Yes & No & Yes \\
\hline Source: UCLG data Collection & \multicolumn{2}{l}{} \\
\hline
\end{tabular}

\begin{tabular}{|l|l|l|l|l|l|l|l|l|}
\hline \multicolumn{2}{|l|}{ Public Finance Indicators } \\
\hline Country & $\begin{array}{l}\text { Total } \\
\text { Expendit } \\
\text { ure in } \\
\text { General } \\
\text { Govt } \\
\text { (Mill } \\
\text { USD) }\end{array}$ & $\begin{array}{l}\text { Total } \\
\text { Expendit } \\
\text { ure in } \\
\text { General } \\
\text { Govt (\% } \\
\text { of GDP) }\end{array}$ & $\begin{array}{l}\text { Local } \\
\text { Expendit } \\
\text { ure (Mill } \\
\text { USD) }\end{array}$ & $\begin{array}{l}\text { Local } \\
\text { Expend } \\
\text { iture } \\
(\% \text { of } \\
\text { GDP) }\end{array}$ & $\begin{array}{l}\text { Local } \\
\text { Expendi } \\
\text { ture } \% \\
\text { of } \\
\text { General } \\
\text { Govt }\end{array}$ & $\begin{array}{l}\text { Local } \\
\text { Revenue } \\
\text { s (Mill } \\
\text { USD) }\end{array}$ & $\begin{array}{l}\text { Local } \\
\text { Govt } \\
\text { Revenues } \\
\text { as \% of } \\
\text { GDP }\end{array}$ & $\begin{array}{l}\text { Local } \\
\text { Govt } \\
\text { Revenues } \\
\text { as \% of } \\
\text { General } \\
\text { Govt }\end{array}$ \\
\hline $\begin{array}{l}\text { Argentina } \\
(2006)\end{array}$ & $\$ 70,468$ & $32.9 \%$ & $\$ 6,204$ & $2.9 \%$ & $8.8 \%$ & $\$ 5,277$ & $2.5 \%$ & $7.3 \%$ \\
\hline $\begin{array}{l}\text { Mexico } \\
(2007)\end{array}$ & $\$ 339,502$ & $31.2 \%$ & $\$ 21,969$ & $2.0 \%$ & $6.5 \%$ & $\$ 23,007$ & $2.1 \%$ & $7.4 \%$ \\
\hline Source: IMF, Ministries of Finance of Argentina (UCLG data Collection) \\
\hline
\end{tabular}

\begin{tabular}{|l|l|l|l|l|l|l|}
\hline Revenues and Expenditures by Government Level (\%) \\
\hline & Revenues (\% total) & Expenditures (\% total) \\
\hline Country & Federal/Central & Regional & Local & Federal/Central & Regional & Local \\
\hline Argentina (2006) & 55 & 38 & 7 & 58 & 33 & 9 \\
\hline Mexico (2007) & 68 & 25 & 7 & 69 & 25 & 6 \\
\hline Source: UCLG data Collection & 7 & & & \\
\hline
\end{tabular}

\begin{tabular}{|l|l|l|l|}
\hline \multicolumn{3}{|l|}{ Budget Expenditures by Economic Classification of Local Governments } \\
\hline $\begin{array}{l}\text { Country (most recent } \\
\text { year) }\end{array}$ & $\begin{array}{l}\text { Wages and Salaries/ } \\
\text { Pension funds (\% of total) }\end{array}$ & $\begin{array}{l}\text { Current Expenditure } \\
\text { other than wages and } \\
\text { salaries (\% of total) }\end{array}$ & $\begin{array}{l}\text { Capital Expenditure/ } \\
\text { Debt / Equipment (\% of } \\
\text { total) }\end{array}$ \\
\hline Argentina (2006) & 47.40 & 29.27 & 23.33 \\
\hline Mexico (2007) & 82.83 & 12.29 & 4.88 \\
\hline Source: UCLG data Collection & \multicolumn{3}{|l|}{} \\
\hline
\end{tabular}




\begin{tabular}{|l|l|l|l|l|l|l|l|l|}
\hline \multicolumn{8}{|c|}{ Origin of Revenues of Local Governments (Millions US\$) } \\
\hline \multicolumn{7}{|c|}{ (\% of total) } & (of GDP) \\
\hline $\begin{array}{l}\text { Country } \\
\text { (most } \\
\text { recent } \\
\text { year) }\end{array}$ & $\begin{array}{l}\text { Own } \\
\text { taxes } \\
\text { and } \\
\text { fees }\end{array}$ & $\begin{array}{l}\text { Shared } \\
\text { Revenu } \\
\text { es }\end{array}$ & $\begin{array}{l}\text { Conditi } \\
\text { onal } \\
\text { Transfe } \\
\text { rs }\end{array}$ & $\begin{array}{l}\text { Uncond } \\
\text { itional } \\
\text { transfer } \\
\text { s/Aid }\end{array}$ & $\begin{array}{l}\text { Own } \\
\text { taxes and } \\
\text { fees }\end{array}$ & $\begin{array}{l}\text { Shared } \\
\text { Revenu } \\
\text { es }\end{array}$ & $\begin{array}{l}\text { Conditional } \\
\text { Transfers }\end{array}$ & $\begin{array}{l}\text { Uncondition } \\
\text { al Transfers/ } \\
\text { Aid }\end{array}$ \\
\hline $\begin{array}{l}\text { Argentina } \\
(2006)\end{array}$ & 49.80 & 42.40 & 0.00 & 7.80 & 1.22 & 1.04 & 0.00 & 0.19 \\
\hline $\begin{array}{l}\text { Mexico } \\
\text { (2007) }\end{array}$ & 15.60 & 45.30 & 0.00 & 39.20 & 2.38 & 6.91 & 0.00 & 5.98 \\
\hline \multicolumn{7}{|l|}{ Source: UCLG data Collection } \\
\hline
\end{tabular}


Appendix 4 - Six Cities Public Finances Reported 1999-2008 


\begin{tabular}{|c|c|c|c|c|c|c|c|c|c|c|c|c|c|c|c|c|c|c|}
\hline $\begin{array}{l}\text { Rosario (UD } \\
\text { Dollars) }\end{array}$ & 2000 & $\%$ & 2001 & $\%$ & 2002 & $\%$ & 2003 & $\%$ & 2004 & $\%$ & 2005 & $\%$ & 2006 & $\%$ & 2007 & $\%$ & 2008 & $\%$ \\
\hline Revenue & $269,366,567$ & 100 & $253,340,305$ & 100 & $79,376,981$ & 100 & $107,476,999$ & 100 & $136,799,608$ & 100 & $162,252,278$ & 100 & $190,647,857$ & 100 & $238,577,006$ & 100 & $285,369,132$ & 100 \\
\hline Transfers & $2,150,664$ & 1 & $1,226,884$ & 0 & 572,859 & 1 & 671,968 & 1 & $2,513,277$ & 2 & $4,467,819$ & 3 & $4,267,634$ & 2 & $12,575,965$ & 5 & $5,090,256$ & 2 \\
\hline TOSR & $267,215,903$ & 99 & $252,113,421$ & 100 & $78,804,122$ & 99 & $106,805,031$ & 99 & $134,286,331$ & 98 & $157,784,459$ & 97 & $186,380,222$ & 98 & $226,001,040$ & 95 & $280,278,876$ & 98 \\
\hline Expenditures & $238,891,154$ & 100 & $246,949,958$ & 100 & $77,915,642$ & 100 & $101,478,277$ & 100 & $122,121,465$ & 100 & $155,070,068$ & 100 & $192,884,079$ & 100 & $244,866,406$ & 100 & $309,596,137$ & 100 \\
\hline Wage Bill & $123,984,835$ & 52 & $130,802,574$ & 53 & $38,183,030$ & 49 & $45,112,010$ & 44 & $53,165,259$ & 44 & $69,857,484$ & 45 & $86,019,961$ & 45 & $117,838,815$ & 48 & $159,309,547$ & 51 \\
\hline Public Works & $29,712,982$ & 12 & $43,190,194$ & 17 & $6,132,417$ & 8 & $11,831,912$ & 12 & $19,777,841$ & 16 & $37,514,967$ & 24 & $38,093,114$ & 20 & $36,945,643$ & 15 & $19,866,976$ & 6 \\
\hline Other & $85,193,337$ & 36 & $72,957,189$ & 30 & $33,600,195$ & 43 & $44,534,355$ & 44 & $49,178,364$ & 40 & $47,697,617$ & 31 & $68,771,003$ & 36 & $90,081,947$ & 37 & $130,419,614$ & 42 \\
\hline Rafaela (US & & & & & & & & & & & & & & & & & & \\
\hline Dollars) & 2000 & $\%$ & 2001 & $\%$ & 2002 & $\%$ & 2003 & $\%$ & 2004 & $\%$ & 2005 & $\%$ & 2006 & $\%$ & 2007 & $\%$ & 2008 & $\%$ \\
\hline Revenue & $24,072,251$ & 100 & $22,746,825$ & 100 & $7,277,612$ & 100 & $9,552,539$ & 100 & $12,743,710$ & 100 & $15,763,158$ & 100 & $20,402,978$ & 100 & $28,363,975$ & 100 & $33,364,824$ & 100 \\
\hline Transfers & $7,970,208$ & 33 & $6,898,377$ & 30 & $2,359,590$ & 32 & $3,109,842$ & 33 & $4,119,140$ & 32 & $5,061,547$ & 32 & $6,254,673$ & 31 & $7,770,262$ & 27 & $9,739,130$ & 29 \\
\hline TOSR & $16,102,042$ & 67 & $15,848,449$ & 70 & $4,918,022$ & 68 & $6,442,698$ & 67 & $8,624,570$ & 68 & $10,701,611$ & 68 & $14,148,305$ & 69 & $20,593,712$ & 73 & $23,625,693$ & 71 \\
\hline Expenditures & $23,782,473$ & 100 & $22,510,526$ & 100 & $6,630,522$ & 100 & $9,805,935$ & 100 & $10,595,757$ & 100 & $15,659,929$ & 100 & $19,929,470$ & 100 & $27,876,174$ & 100 & $33,287,002$ & 100 \\
\hline Wage Bill & $9,502,393$ & 40 & $9,668,623$ & 43 & $2,863,777$ & 43 & $3,321,566$ & 34 & $3,939,440$ & 37 & $5,358,015$ & 34 & $6,589,546$ & 33 & $8,699,176$ & 31 & $11,288,194$ & 34 \\
\hline Public Works & 474,449 & 2 & 467,327 & 2 & 237,772 & 4 & 371,988 & 4 & 413,973 & 4 & 488,272 & 3 & 602,764 & 3 & 778,082 & 3 & 793,481 & 2 \\
\hline Other & $13,805,631$ & 58 & $12,374,576$ & 55 & $3,528,974$ & 53 & $6,112,381$ & 62 & $6,242,345$ & 59 & $9,813,642$ & 63 & $12,737,160$ & 64 & $18,398,917$ & 66 & $21,205,327$ & 64 \\
\hline
\end{tabular}




\begin{tabular}{|c|c|c|c|c|c|c|c|c|c|c|c|c|c|c|c|c|c|c|}
\hline $\begin{array}{l}\text { Santa Fe in } \\
\text { US Dollars }\end{array}$ & 2000 & $\%$ & 2001 & $\%$ & 2002 & $\%$ & 2003 & $\%$ & 2004 & $\%$ & 2005 & $\%$ & 2006 & $\%$ & 2007 & $\%$ & 2008 & $\%$ \\
\hline Revenue & $\mathrm{n} / \mathrm{a}$ & $\mathrm{n} / \mathrm{a}$ & $\mathrm{n} / \mathrm{a}$ & $\mathrm{n} / \mathrm{a}$ & $24,148,126$ & 100 & $\mathrm{n} / \mathrm{a}$ & $\mathrm{n} / \mathrm{a}$ & $1,016,291$ & 100 & $1,536,551$ & 100 & $2,163,639$ & 100 & $6,453,005$ & 100 & $1,100,426$ & 100 \\
\hline Transfers & $\mathrm{n} / \mathrm{a}$ & $\mathrm{n} / \mathrm{a}$ & $\mathrm{n} / \mathrm{a}$ & $\mathrm{n} / \mathrm{a}$ & $11,977,582$ & 50 & $\mathrm{n} / \mathrm{a}$ & $\mathrm{n} / \mathrm{a}$ & 0 & 0 & 297,509 & 19 & 255,251 & 12 & 352,658 & 5 & 118,044 & 11 \\
\hline TOSR & $\mathrm{n} / \mathrm{a}$ & $\mathrm{n} / \mathrm{a}$ & $\mathrm{n} / \mathrm{a}$ & $\mathrm{n} / \mathrm{a}$ & $12,170,544$ & 50 & $\mathrm{n} / \mathrm{a}$ & $\mathrm{n} / \mathrm{a}$ & $1,016,291$ & 100 & $1,239,042$ & 81 & $1,908,388$ & 88 & $6,100,346$ & 95 & 982,382 & 89 \\
\hline Expenditures & $\mathrm{n} / \mathrm{a}$ & $\mathrm{n} / \mathrm{a}$ & $\mathrm{n} / \mathrm{a}$ & $\mathrm{n} / \mathrm{a}$ & $24,435,797$ & 100 & $\mathrm{n} / \mathrm{a}$ & $\mathrm{n} / \mathrm{a}$ & $39,061,005$ & 100 & $59,407,330$ & 100 & $63,880,732$ & 100 & $109,420,944$ & 100 & $91,955,249$ & 100 \\
\hline Wage Bill & $\mathrm{n} / \mathrm{a}$ & $\mathrm{n} / \mathrm{a}$ & $\mathrm{n} / \mathrm{a}$ & $\mathrm{n} / \mathrm{a}$ & $19,157,682$ & 78 & $\mathrm{n} / \mathrm{a}$ & $\mathrm{n} / \mathrm{a}$ & $24,805,138$ & 64 & $29,476,616$ & 50 & $33,477,975$ & 52 & $43,625,937$ & 40 & $56,795,796$ & 62 \\
\hline Public Workds & $\mathrm{n} / \mathrm{a}$ & $\mathrm{n} / \mathrm{a}$ & $\mathrm{n} / \mathrm{a}$ & $\mathrm{n} / \mathrm{a}$ & 514,868 & 2 & $\mathrm{n} / \mathrm{a}$ & $\mathrm{n} / \mathrm{a}$ & $2,579,695$ & 7 & $8,758,596$ & 15 & $7,053,335$ & 11 & $19,780,996$ & 18 & $3,039,213$ & 3 \\
\hline Other & $\mathrm{n} / \mathrm{a}$ & $\mathrm{n} / \mathrm{a}$ & $\mathrm{n} / \mathrm{a}$ & $\mathrm{n} / \mathrm{a}$ & $4,763,246$ & 19 & $\mathrm{n} / \mathrm{a}$ & $\mathrm{n} / \mathrm{a}$ & $11,676,172$ & 30 & $21,172,118$ & 36 & $23,349,422$ & 37 & $46,014,012$ & 42 & $32,120,241$ & 35 \\
\hline León (US & & & & & & & & & & & & & & & & & & \\
\hline Dollars) & 2000 & $\%$ & 2001 & $\%$ & 2002 & $\%$ & 2003 & $\%$ & 2004 & $\%$ & 2005 & $\%$ & 2006 & $\%$ & 2007 & $\%$ & 2008 & $\%$ \\
\hline Revenue & $108,593,095$ & 100 & $146,166,546$ & 100 & $151,157,991$ & 100 & $141,069,739$ & 100 & $136,102,509$ & 100 & $180,842,346$ & 100 & $205,577,417$ & 100 & $199,222,169$ & 100 & $206,588,748$ & 100 \\
\hline Transfers & $70,057,976$ & 65 & $87,252,333$ & 60 & $73,992,805$ & 49 & $70,758,040$ & 50 & $80,548,609$ & 59 & $123,677,854$ & 68 & $102,909,627$ & 50 & $129,103,884$ & 65 & $146,274,699$ & 71 \\
\hline TOSR & $38,535,118$ & 35 & $58,914,213$ & 40 & $77,165,186$ & 51 & $70,311,699$ & 50 & $55,553,899$ & 41 & $57,164,493$ & 32 & $102,667,790$ & 50 & $70,118,285$ & 35 & $60,314,048$ & 29 \\
\hline Expenditures & $108,593,095$ & 100 & $146,166,546$ & 100 & $151,157,991$ & 100 & $141,069,739$ & 100 & $136,102,509$ & 100 & $180,842,346$ & 100 & $205,577,417$ & 100 & $199,222,169$ & 100 & $206,588,748$ & 100 \\
\hline Wage Bill & $33,788,604$ & 31 & $39,110,690$ & 27 & $44,807,429$ & 30 & $46,633,269$ & 33 & $52,244,293$ & 38 & $60,353,100$ & 33 & $74,354,420$ & 36 & $74,812,724$ & 38 & $65,963,364$ & 32 \\
\hline Public Works & 56,741 & 0 & 0 & 0 & 70,333 & 0 & 0 & 0 & 0 & 0 & 0 & 0 & 0 & 0 & 0 & 0 & 0 & 0 \\
\hline Other & $74,747,749$ & 69 & $107,055,856$ & 73 & $106,280,228$ & 70 & $94,436,470$ & 67 & $83,858,216$ & 62 & $120,489,246$ & 67 & $131,222,997$ & 64 & $124,409,445$ & 62 & $140,625,384$ & 68 \\
\hline
\end{tabular}




\begin{tabular}{|c|c|c|c|c|c|c|c|c|c|c|c|c|c|c|c|c|c|c|}
\hline \multirow{2}{*}{$\begin{array}{l}\text { San Miguel de } \\
\text { Allende (US } \\
\text { Dollars) }\end{array}$} & \multirow[b]{2}{*}{2000} & \multirow[b]{2}{*}{$\%$} & \multirow[b]{2}{*}{2001} & \multirow[b]{2}{*}{$\%$} & \multirow[b]{2}{*}{2002} & \multirow[b]{2}{*}{$\%$} & \multirow[b]{2}{*}{2003} & \multirow[b]{2}{*}{$\%$} & \multirow[b]{2}{*}{2004} & \multirow[b]{2}{*}{$\%$} & \multirow[b]{2}{*}{2005} & \multirow[b]{2}{*}{$\%$} & \multirow[b]{2}{*}{2006} & \multirow[b]{2}{*}{$\%$} & \multirow[b]{2}{*}{2007} & \multirow[b]{2}{*}{$\%$} & \multirow[b]{2}{*}{2008} & \multirow[b]{2}{*}{$\%$} \\
\hline & & & & & & & & & & & & & & & & & & \\
\hline Revenue & $15,677,426$ & 100 & $16,331,195$ & 100 & $22,887,082$ & 100 & $15,903,796$ & 100 & $20,982,027$ & 100 & $30,370,852$ & 100 & $30,694,486$ & 100 & $28,894,531$ & 100 & $31,332,180$ & 100 \\
\hline Transfers & $9,232,063$ & 59 & $10,327,664$ & 63 & $11,754,254$ & 51 & $12,191,901$ & 77 & $8,167,816$ & 39 & $16,093,942$ & 53 & $15,041,226$ & 49 & $20,189,211$ & 70 & $23,426,563$ & 75 \\
\hline TOSR & $6,445,364$ & 41 & $6,003,531$ & 37 & $11,132,828$ & 49 & $3,711,894$ & 23 & $12,814,210$ & 61 & $14,276,910$ & 47 & $15,653,260$ & 51 & $8,705,320$ & 30 & $7,905,617$ & 25 \\
\hline Expenditures & $15,677,426$ & 100 & $16,331,195$ & 100 & $22,887,082$ & 100 & $15,903,796$ & 100 & $20,982,027$ & 100 & $30,370,852$ & 100 & $30,694,486$ & 100 & $28,894,531$ & 100 & $31,332,180$ & 100 \\
\hline Wage Bill & $3,085,234$ & 20 & $4,005,728$ & 25 & $3,822,417$ & 17 & $3,690,664$ & 23 & $4,657,263$ & 22 & $5,448,154$ & 18 & $5,645,168$ & 18 & $6,794,911$ & 24 & $5,126,923$ & 16 \\
\hline Public Works & $7,044,150$ & 45 & $3,478,684$ & 21 & $10,098,125$ & 44 & $5,585,883$ & 35 & $4,718,906$ & 22 & $15,171,977$ & 50 & $18,701,538$ & 61 & $14,828,998$ & 51 & $12,178,086$ & 39 \\
\hline Other & $5,548,043$ & 35 & $8,846,783$ & 54 & $8,966,540$ & 39 & $6,627,248$ & 42 & $11,605,858$ & 55 & $9,750,722$ & 32 & $6,347,780$ & 21 & $7,270,622$ & 25 & $14,027,170$ & 45 \\
\hline \multicolumn{19}{|l|}{$\begin{array}{l}\text { Guanajuato } \\
\text { Capital (US }\end{array}$} \\
\hline Dolars) & 2000 & $\%$ & 2001 & $\%$ & 2002 & $\%$ & 2003 & $\%$ & 2004 & $\%$ & 2005 & $\%$ & 2006 & $\%$ & 2007 & $\%$ & 2008 & $\%$ \\
\hline Revenue & $15,802,259$ & 100 & $16,953,217$ & 100 & $18,728,504$ & 100 & $16,873,440$ & 100 & $20,771,172$ & 100 & $24,982,954$ & 100 & $25,126,586$ & 100 & $25,618,461$ & 100 & $23,924,838$ & 100 \\
\hline Transfers & $5,944,363$ & 38 & $1,102,011$ & 7 & $1,125,086$ & 6 & $1,223,516$ & 7 & $1,247,961$ & 6 & $1,170,605$ & 5 & 996,304 & 4 & $1,086,233$ & 4 & $1,162,204$ & 5 \\
\hline TOSR & $9,857,896$ & 62 & $15,851,206$ & 93 & $17,603,419$ & 94 & $15,649,924$ & 93 & $19,523,211$ & 94 & $23,812,349$ & 95 & $24,130,282$ & 96 & $24,532,228$ & 96 & $22,762,634$ & 95 \\
\hline Expenditures & $15,802,259$ & 100 & $16,953,217$ & 100 & $18,728,504$ & 100 & $16,873,440$ & 100 & $20,771,172$ & 100 & $24,982,954$ & 100 & $25,126,586$ & 100 & $25,618,461$ & 100 & $23,924,838$ & 100 \\
\hline Wage Bill & $6,385,146$ & 40 & $7,652,615$ & 45 & $6,966,477$ & 37 & $6,581,644$ & 39 & $7,052,613$ & 34 & $9,363,344$ & 37 & $11,831,159$ & 47 & $12,338,358$ & 48 & $10,647,145$ & 45 \\
\hline Public Works & $4,696,757$ & 30 & $2,221,386$ & 13 & $2,518,573$ & 13 & $7,332,960$ & 43 & $8,984,826$ & 43 & $10,515,082$ & 42 & $5,152,108$ & 21 & $3,585,351$ & 14 & $2,857,290$ & 12 \\
\hline Other & $4,720,357$ & 30 & $7,079,216$ & 42 & $9,243,454$ & 49 & $2,958,836$ & 18 & $4,733,733$ & 23 & $5,104,528$ & 20 & $8,143,319$ & 32 & $9,694,752$ & 38 & $10,420,403$ & 44 \\
\hline
\end{tabular}




\section{VITA}

\section{HEIDI JANE M. SMITH}

April 18, 1977

Winter 1999

Winter 2002

April 2000-Sept. 2001

Sept. 2001-Sept. 2007

Sept. 2007- Oct. 2009

Oct. 2009— Present
Born, Bemidji, Minnesota

B.A. Political Science, Spanish and LAC Studies

University of Wisconsin, Madison

Madison, Wisconsin

M.P.P. Master in Public Policy

American University

Washington, DC

Democracy and Decentralization Consultant

Organization of American States

Washington, DC

Public Affairs Specialist

Inter-American Foundation

Arlington, Virginia

Teaching and Research Assistant

Florida International University

Miami, Florida

Economic Advisor, Bureau of Western Hemisphere Affairs

U.S. Department of State

Washington, DC

\section{PUBLICATIONS AND PRESENTATIONS}

Smith, Heidi Jane M. (2008) "Book Review: Fiscal Federalism in Latin America: From Entitlements to Markets by Eduardo Wiesner," Public Budget and Finance 28(4) 111-113.

Smith, Heidi Jane M. (July 2008) Latin American Bond Market: Experiences from Mexico and Argentina paper presented at the International Association of Schools and Institutes of Administrative Sciences (IASIA) Conference, Kampala Uganda.

Smith, Heidi Jane M. (July 2009) Innovations in Local Financing for Economic Development: Cases from Latin America, paper presented at the 53rd International Congress of Americanists (ICA), Mexico City. 
Smith, Heidi Jane M. (August 2009) Explaining Local Economic Development Success in Latin America, paper presented at the International Association of Schools and Institutes of Administrative Sciences (IASIA) Annual Conference, Rio de Janeiro, Brazil (awarded best conference paper).

Smith, Heidi Jane M. (March 2010) Local Economic Development and its Implications for the Energy and Climate Partnership of the Americas (ECPA) presentation for Habitat for Humanity at the World Urban Forum, Rio de Janeiro, Brazil.

Smith, Heidi Jane M. (September 2010) Fiscal Decentralization: Explaining Local Economic Development Success in Latin America, paper presented at the American Political Science Association (APSA) Annual Meeting and Exhibition, Washington, DC.

Smith, Heidi Jane M. (May 2011) Fiscal Decentralization: Explaining Local Economic Development Success In Latin America, paper presented at the International Research Society for Public Management Regional Conference, University of Brasilia, Brazil.

Smith, Heidi Jane M. (June 2011) Fiscal Decentralization and Growth: An Analysis of City Governments in Argentina and Mexico invited presentation at the Red Inter-Americana de Educación en Administración Pública, INPAE Conference, hosted by CIDE, Mexico City.

Smith, Heidi Jane M. (September 2011) Effective Public Service Delivery in Latin America: Can it be done at the Local Level? Poster presentation at the American Political Science Association (APSA) Annual Meeting, Seattle, Washington.

Smith, Heidi Jane M. (March 2012) Private vs. Public Debt: Explaining Borrowing Patterns of Mexican Cities, paper presented at the American Society for Public Administration Annual Meeting, Las Vegas.

Smith, Heidi Jane M. (May 2012) Sustainable Housing and Planning in the Americas, paper presented at the XXX International Congress of the Latin American Studies Association (LASA), San Francisco. 